\begin{abstract}
UNIVERSIDADE DE SÃO PAULO
FACULDADE DE FILOSOFIA, LETRAS E CIÊNCIAS HUMANAS

PROGRAMA DE PÓS-GRADUAÇÃO EM GEOGRAFIA HUMANA
\end{abstract}

ANDRÉ EDUARDO RIBEIRO DA SILVA

Territorialidades e Redes da Migração Maranhense para o

Trabalho nos Canaviais Paulistas

São Paulo

2012 


\begin{abstract}
UNIVERSIDADE DE SÃO PAULO
FACULDADE DE FILOSOFIA, LETRAS E CIÊNCIAS HUMANAS

PROGRAMA DE PÓS-GRADUAÇÃO EM GEOGRAFIA HUMANA
\end{abstract}

\title{
Territorialidades e Redes da Migração Maranhense nos Canaviais Paulistas
}

\author{
André Eduardo Ribeiro da Silva \\ Tese apresentada à Faculdade de \\ Filosofia, Letras e Ciências Humanas \\ da Universidade de São Paulo para \\ obtenção do título de Doutor em \\ Ciências.
}

Orientador: Dr. Júlio César Suzuki

São Paulo

2012 


\section{FOLHA DE APROVAÇÃO}

André Eduardo Ribeiro da Silva

Territorialidades e Redes da Migração

Maranhense nos Canaviais Paulistas

Tese apresentada à Faculdade de Filosofia, Letras e Ciências Humanas da Universidade de São Paulo para obtenção do título de Doutor em Ciências

Aprovado em

\section{Banca Examinadora}

Prof. Dr.

Instituição:

Assinatura:

Prof. Dr.

Instituição:

Assinatura:

Prof. Dr.

Instituição:

Assinatura:

Prof. Dr.

Instituição:

Assinatura:

Prof. Dr.

Instituição:

Assinatura: 
À Rosana companheira de vida e das esperanças que construímos juntos. Estrela que ilumina o horizonte e dá substância ao nosso caminhar. A sua presença foi essencial para a realização da tese. A ti, com toda a grandeza e com todo o meu amor, dedico esta tese. 


\section{Agradecimentos}

Agradeço especialmente ao meu orientador, Prof. Dr. Júlio César Suzuki pela dedicação, paciência, confiança e aprendizado despendidos durante a construção da tese, e desde o desenvolvimento da dissertação de Mestrado a partir de 2004. As suas contribuições foram fundamentais, sobretudo em momentos ofuscados por labirintos traiçoeiros experimentados na relação e no desenvolvimento da pesquisa.

Aos meus pais, por incentivar os meus estudos, pela força e encorajamento que me fortalece diante dos desafios e experiências da vida. Pela compreensão diante das sucessivas ausências durante o Doutorado.

Aos amigos que desde a graduação preenchem o coração com afeto, muita amizade e carinho: Fabiana, Carlos Renato, Aline e Sergio, companheiros para "o que der e vier", que deram força nos momentos de incerteza, sustentação para enfrentar os desafios e presença em diferentes contextos da construção da tese.

Aos amigos, contemporâneos de orientação e do Colóquio, pelas discussões fecundas que enriqueceram o processo de reflexão da tese, compartilhando angústias que inquietam nossos trabalhos, acalentando esperanças que dão forças no caminhar.

A Samarone Carvalho Marinho, pelas contribuições substanciais na concretização das pesquisas de campo no Estado do Maranhão e pelos diálogos que, em diferentes e atribulados períodos, deram vigor ao processo de construção da tese. Os agradecimentos se estendem a dona Da Graça e Seu Marinho, que nos acolheu durante o trabalho de campo em São Luís, em janeiro de 2010. A Greta, Tazinho,Eunice e Ataniel pela estadia calorosa e pelo auxílio na pesquisa em São Luís, em janeiro de 2011.

Aos funcionários da Biblioteca Florestan Fernandes, em especial à Marta, sempre solícita e prestativa no encaminhamento de teses e dissertações originárias de várias universidades e centros de pesquisa do país.

A Antônio e Roberto, agentes da Pastoral da Juventude em Timbiras, mediadores essenciais na pesquisa de campo. 
Aos padres e religiosas palotinos, instalados em Codó e Timbiras, em particular o padre Bento e a irmã Maria, representantes da Comissão Pastoral da Terra (CPT) local e articuladores das pastorais sociais, pela intermediação na pesquisa de campo e pelo encorajamento social para a luta por justiça e condições dignas de vida no campo deste país, e em particular na diocese de Coroatá, no Maranhão.

Às coordenadoras do Serviço Pastoral do Migrante na cidade de Guariba, irmã Inês e, posteriormente irmã Terezinha, pela mediação na pesquisa de campo na cidade de Guariba junto aos trabalhadores e famílias maranhenses.

A Camila, Felipe e Marília pela elaboração e cuidado na confecção dos mapas.

Aos funcionários da Secretaria do Programa de Pós-Graduação em Geografia Humana: Firmino, Ana, Cida, Jurema e Rosângela, pela solicitez e auxílio sempre que necessário.

Sou grato aos estudantes e colegas de trabalho pelos incentivos e reflexões despertados durante os nossos encontros e aulas.

À banca de qualificação, representada pelos professores Dra. Suzana Lopes Salgado Ribeiro e Dr. Samarone Carvalho Marinho, pelas contribuições que encorajaram o pesquisador e deram substância à redação final da tese.

Aos funcionários que acolheram o pesquisador com atenção e muito carinho durante o período de levantamento de dados nas seguintes instituições: escritório regional do IBGE, em São Luís e São Paulo, Arquivo Público e Histórico do Maranhão, Instituto de Economia Agrícola do Estado de São Paulo, Instituto Geográfico e Cartográfico do Estado de São Paulo, Biblioteca Central e Biblioteca do Programa de Mestrado em Políticas Públicas da UFMA, Biblioteca Municipal de Pradópolis, Centro de Estudos Migratórios de São Paulo e Centro de Estudios Migratorios Latinoamericanos de Buenos Aires.

Aos professores Dr. Marcelo Domingos Sampaio Carneiro e Maria Aparecida de Moraes Silva, pelos ensinamentos, sugestões bibliográficas e reflexões que despertam por meio de seus estudos a pensar na construção deste trabalho. Vocês foram fundamentais na sustentação da tese e no encorajamento do pesquisador, nestas idas e vindas do pesquisador, na pesquisa de campo entre os Estados do Maranhão e de São Paulo. 
Ao pesquisador Paulo Jeferson Pilar Araújo, pelas informações valiosas que viabilizaram as condições operacionais para a realização da primeira pesquisa de campo na cidade de Codó, em janeiro de 2011.

Á CAPES, pela concessão de bolsa de estudo no último ano do Doutorado, auxílio financeiro fundamental para levar adiante a pesquisa.

Aos trabalhadores e famílias maranhenses, que gentilmente nos receberam em sua casa no Maranhão ou na sua residência alugada em Timbiras e Codó para contar sobre a sua vida, suas experiências migratórias e a de seus familiares, construindo momentos que transformaram a minha vida, e a minha relação com o trabalho docente e intelectual. Vocês foram a força inspiradora que moveu ideias e montanhas para a realização deste trabalho. O meu agradecimento é sem limites, e seria ingênuo se reduzisse a poucas palavras. Ele apenas suspende o início de um diálogo que deu substância a esta tese e dá sentido ao meu esforço intelectual de fazer uma leitura do mundo e da Geografia. 
RESUMO

SILVA, A. E. R. Territorialidades e redes da migração maranhense nos canaviais paulistas. 2012. Tese (doutorado em Geografia Humana) Departamento de Geografia da Faculdade de Filosofia, Letras e Ciências Humanas da Universidade de São Paulo. São Paulo, 2012.

Os deslocamentos de homens, mulheres e famílias inteiras, moradoras no município de Timbiras/MA para o labor nas atividades da agricultura canavieira no Estado de São Paulo se desenrola por uma série de redes de relações pessoais, que abrange diversos agentes sociais, tanto no Maranhão no município timbirense e também em municípios vizinhos - como nas duas principais cidades em que residem durante a colheita da gramínea, no Estado de São Paulo: Guariba e Pradópolis.

Por meio de testemunhos orais, colhidos no município de Timbiras (MA) e nas cidades paulistas de Guariba e Pradópolis, buscamos compreender as relações entre a rede de informações familiares e as redes territoriais de apoio que fundamentam o processo migratório. A primeira se sustenta a partir de vínculos de reciprocidade nutridos pelos trabalhadores migrantes nos espaços sociais das referidos municípios do Estado do Maranhão e de São Paulo. Já as redes territoriais de apoio dão suporte a essa troca de informações entre os territórios de migração e o dito local de moradia do tronco ou núcleo familiar, no Maranhão nos anos 2000.

Essas redes de relações pessoais, fundamentais para alavancar a experiência migratória, se costuram, se refiguram e se fortalecem a partir de múltiplas formas de trocas de informações entre os que migraram e os que não migraram, bem como entre os possíveis migrantes e os agentes responsáveis pelo processo de deslocamento e recrutamento até a área canavieira paulista.

Compreende-se que há uma vinculação estreita entre o processo de construção de territórios de migração e a territorialidade experimentada na área de origem, sustentada por redes múltiplas de relações sociais que cimentam estas territorialidades criadas e ressignificadas com a migração.

Palavras-chave: Territorialidade Migratória - Redes territoriais - Relações de trabalho - Lavoura canavieira - Reprodução social camponesa 


\section{ABSTRACT}

SILVA, A. E. R. Territoriality and networks of the migration from Maranhao to Sao Paulo cane fields. 2012. Thesis (Ph.D. in Human Geography) Department of Geography, Faculty of Philosophy and Humanities at the University of São Paulo. São Paulo, 2012.

The displacements of men, women and entire families living in the city of Timbiras/MA for labor in agricultural activities of sugarcane in the state of São Paulo unfolds through a series of networks of personal relationships, covering many different social agents, both in Maranhão - in the city of Timbiras and in neighboring counties as well - and in the two major cities where they live during the harvest of sugarcane, in the State of São Paulo: Guariba and Pradópolis.

By oral testimonies, collected in the municipality of Timbiras (MA) and in the cities of Guariba (SP) and Pradópolis (SP), we sought to achieve the understanding of the relationships between the network of family information and territorial networks of support that underlie the migration process. The first is based on the bonds of reciprocity fed by migrant workers in the social spaces of these referred cities in the state of Maranhão and São Paulo. The territorial networks of support gives a base to this exchange of information between the territories of migration and the place of residence of core of the family, in Maranhão in the year of 2000.

These networks of personal relationships, fundamental to leverage the experience of migration, sew themselves get strengthened from multiple forms of information exchange between those who migrated and those who did not, as well as among potential migrants and the agents responsible for the process displacement and recruitment to the sugarcane production area in São Paulo.

It was possible to understand that there is a close relationship between the process of construction of territories of migration and the territoriality experienced in the area of origin, supported by multiple networks of social relationships that cement these territorialities created and re-signified with the migration.

Keywords: Migration Territoriality - Territorial Networks - Labor Relations - Crop sugarcane - peasant social reproduction 


\section{LISTA DE SIGLAS}

CAI - Complexo Agroindustrial

CIT - Companhia Industrial Técnica

CPT - Comissão Pastoral da Terra

EIB - Empresa Industrial de Bacabal

FINOR - Fundo de Investimento do Nordeste

FINAM - Fundo de Investimento da Amazônia

FISET - Fundo de Investimentos Setoriais

GEPLAN - Gerência de Estado de Planejamento e Desenvolvimento

Econômico do Estado do Maranhão

IBGE - Instituto Brasileiro de Geografia e Estatística

INCRA - Instituto Nacional de Colonização e Reforma Agrária

IPES - Instituto de Pesquisas Econômicas e Sociais

MRG - Microrregião Geográfica

Proálcool - Programa Nacional do Álcool

R.F.F.S.A - Rede Ferroviária Federal S.A.

SIDRA - Sistema IBGE de Recuperação Automática

SINDEC - Sistema Nacional de Defesa Civil

ZEEMA - Zoneamento Ecológico- Econômico do Estado do Maranhão 


\section{LISTA DE FOTOGRAFIAS}

Figura 1 - Velhos caminhos de trem. Estação abandonada da antiga ferrovia São Luís - Teresina que passa pelo município de Timbiras, e divide o bairro São Sebastião no núcleo urbano. 25

Figura 2 - A ponte para cair. Destruição da estrutura de ponte na rodovia MA 235 nas proximidades do núcleo urbano de Coroatá/MA em razão das fortes chuvas que provocaram inundações na bacia hidrográfica do rio Itapecuru, no Estado do Maranhão, entre o final de abril e início de maio de 2009. 27

Figura 3 - Duas rodas. Motocicletas estacionadas próximas à feira semanal na cidade de Timbiras/MA. 30

Figura 4 - Caminho pelo interior. Vista parcial da via de comunicação do povoado Flores, no município de Timbiras/MA. As motocicletas hoje realizam o importante papel de permitir o intercâmbio material e simbólico entre a cidade e os povoados e roças do interior do município de Timbiras 32

Figura 5 - Roça da família. Cultivos alimentares (feijão) no roçado da família, em meio aos babaçuais, a poucos minutos da morada da família, no povoado Pedra Preta, interior do município de Timbiras/MA. 56

Figura 6 - Divisa. Os tocos cortados e os galhos dispostos horizontalmente são o único marco visível na delimitação dos cultivos familiares. Povoado Pedra Preta, Timbiras/MA. 57

Figura 7 - Cozendo com afeto. Dona Raimunda cozinha o mingau de mesocarpo do coco babaçu, em um fogão de barro erigido sobre uma carcaça de fogão à gás. Ela faz o cozimento do alimento em um "puxado" da casa, sem luz, daí o uso de uma lanterna a pilhas. Bairro São Raimundo, Timbiras/MA.. 59

Figura 8 - Quebra do coco babaçu. Antônia, 51, mostra em um puxadinho em sua residência a atividade de quebra do coco babaçu em Codó/MA

Figura 9 - Coco queimado. Carvão do coco babaçu utilizado para atividades domésticas e também comercializado em Codó/MA. 62 
Figura 10 - Publicidade de produto do Grupo Maratá em parede externa de estabelecimento comercial no Bairro São Raimundo, em Codó/MA. 65

Figura 11- Feira livre. Venda de produtos na feira de terça na cidade de Timbiras/MA. 84

Figura 12 - De volta para o "interior". Retorno de moradores aos povoados do interior do município de Timbiras após o término da feira livre de terça na cidade. Foto do autor, 18 de Janeiro de 2011. 86

Figura 13 - Vale alagado. Vista sobre a ponte José Sarney, que liga o bairro de Olaria, à esquerda da foto, ao bairro de São Sebastião, encontrado a esquerda da imagem na cidade de Timbiras/MA. 93

Figura 14 - Vista do Bairro São Sebastião. Na margem esquerda do rio. O bairro São Sebastião, encontrado na margem côncava de um meandro do rio Itapecuru teve extensas áreas atingidas pela cheia do curso fluvial em abril/maio de 2009. Foto cedida pelo SINDEC. Pesquisa de campo em 18 de Janeiro de 2011. .93

Figura 15 - Comunidade. Fachada do prédio da Associação de Moradores do Bairro São Sebastião, no núcleo urbano de Timbiras/MA. .94

Figura 16 - Mudança nos padrões construtivos das casas do núcleo urbano de Timbiras/MA. 97

Figura 17 - Contraste. Construção de casa de alvenaria ao lado de uma moradia com paredes de adobe na cidade de Timbiras/MA. 98

Figura 18 - Laços sagrados. Igreja de São Sebastião, no bairro do mesmo nome na cidade de Timbiras/MA. 99

Figura 19 - Território da unidade processadora de cana-de-açúcar. Acesso da rodovia Deputado Cunha Bueno (SP 253) à Usina São Martinho, no sentido Guariba- Pradópolis. 108

Figura 20 - Árvore solitária em meio ao mar de cana. Rodovia Deputado Cunha Bueno (SP-253), no sentido Pradópolis - Luís Antônio, no município de Guatapará/SP. 110 
Figura 21 - Trabalho distante. Trabalhadores rurais à espera dos ônibus rurais que os conduzirão a mais um dia de labor nos canaviais e laranjais da região. Bairro Alto, Guariba/SP. 133

Figura 22 - Caminho para o eito. Transporte de trabalhadores canavieiros em ônibus rural, para os talhões de cana da LDC Bioenergia- unidade São Carlos. Bairro Alto, Guariba/SP. 134

Figura 23 - Distante do centro. Jardim Maria Luisa II, periferia urbana de Pradópolis/SP. 148

Figura 24 - Espaço de sociabilidade maranhense, sobretudo masculino, na cidade da cana. Bar do Codó, centro de Pradópolis/SP. 153

Figura 25 - Comércio de maranhense. Estabelecimento comercial de extrabalhador canavieiro maranhense no centro de Pradópolis/SP. 153

Figura 26 - Guariba do café. Vista do núcleo urbano de Guariba/SP. 159

Figura 27 - Sindicato no centro. Fachada do Sindicato dos Empregados Rurais Assalariados de Guariba, no centro da cidade. 165

Figura 28 - Bumba meu boi maranhense em Guariba. Trabalhadores rurais reproduzem a festa do Bumba meu Boi, em Guariba/SP, em 2008. 168

Figura 29 - Agência de viagem na cidade de Codó/MA. 190

Figura 30 - Agência de viagem na cidade de Codó/MA. 190

Figura 31 - Agência de viagem na cidade de Coroatá. 191

Figura 32 - É hora de partir. Arrumação das malas e pertences pessoais no bagageiro de ônibus clandestino em Timbiras/MA. 196

Figura 33 - Terra arrasada. Destruição dos babaçuais em faixa de terras próxima à rodovia MA 235, sentido Coroatá -Timbiras. ................................. 200

Figura 34 - Chegada dos filhos da terra (1). Coroatá/MA............................ 201

Figura 35 - Chegada dos filhos da terra (2). Coroatá/MA............................. 202 
Figura 36 - Despedida da família em Pradópolis/SP. Raimundo auxilia o pai a instalar-se no ônibus clandestino, rumo a Timbiras, no Maranhão. Era próximo das 22 horas e seriam mais três dias de viagem até os pais desembarcarem no município maranhense. Pradópolis/SP 211

Figura 37 - No interior do ônibus clandestino. Após passar por várias sedes de municípios canavieiros do nordeste paulista, o ônibus parte lotado para os locais de origem das famílias dos trabalhadores migrantes. Pradópolis/SP. . 212 


\section{LISTA DE TABELAS}

Tabela 1 - Timbiras/MA: Frota total e principais tipos de veículos emplacados (2001- 2011). 28

Tabela 2 - Timbiras/MA: Frota total, crescimento absoluto e relativo de motocicletas emplacadas (2001 - 2011) 29

Tabela 3 - População Urbana e Rural do município de Timbiras e do Estado do Maranhão (1991, 2000 e 2010). 34

Tabela 4 - Microrregião geográfica de Codó/MA : Conflitos por Terra (2009).. 71

Tabela 5 - Microrregião geográfica de Codó/MA e Estado do Maranhão: Agentes sociais, Número de Ocorrências e de Famílias Envolvidos nos Conflitos de Terra (2009). 76

Tabela 6 - Microrregião geográfica de Codó/MA e Estado do Maranhão: Número de ocorrências e de famílias em relação ao número total de conflitos por categoria (2009). 77

Tabela 7 - Microrregião geográfica de Codó/MA: Conflitos por Terra (2010) .. 79

Tabela 8 - Microrregião geográfica de Codó/MA e Estado do Maranhão: Agentes sociais envolvidos nos conflitos de terra - Número de ocorrências e de famílias (2010).

Tabela 9 - Microrregião geográfica de Codó/MA e Estado do Maranhão: Número de ocorrências e de famílias em relação ao número total de conflitos por categoria no Estado (2010).

Tabela 10 - Brasil, Centro-Sul Canavieiro e Estado de São Paulo. Cana moída (em toneladas) entre as safras 2000/2001 - 2010/2011. 104

Tabela 11 - Brasil, Centro-Sul Canavieiro e Estado de São Paulo. Produção de açúcar (em toneladas) entre as safras 2000/2001 - 2010/2011. 105

Tabela 12 - Brasil, Centro-Sul Canavieiro e Estado de São Paulo. Produção de álcool anidro e hidratado $\left(\mathrm{em} \mathrm{m}^{3}\right)$ entre as safras 2000/2001-2010/2011 ... 106 
Tabela 13 - Últimas usinas empregadoras dos entrevistados 109

Tabela 14 - Cana-de-açúcar moída (em toneladas) pelas principais unidades processadoras que empregaram trabalhadores originários de Timbiras/MA e alocados em Guariba e Pradópolis. Safras 2001 - 2002 / 2010 - 2011.

Tabela 15 - Período de trabalho nos canaviais, de acordo com os entrevistados.

Tabela 16 - Pradópolis/SP: População Total, Rural e Urbana (1970 - 2010). 146

Tabela 17 - Guariba/SP: População Total, Rural e Urbana (1970 - 2010). .... 163

Tabela 18 - Número estimado de trabalhadores migrantes do Estado do Maranhão e do Piauí para o Estado de São Paulo. 166

Tabela 19 - Faixa etária dos integrantes da família de trabalhadores maranhenses entrevistados.

216

Tabela 20 - Faixa de idade dos maranhenses entrevistados que trabalharam na safra canavieira paulista $(2000$ - 2011). 217

Tabela 21 - Estado civil dos maranhenses entrevistados que trabalharam na safra canavieira paulista $(2000$ - 2011). 218

Tabela 22 - Localização da residência do núcleo familiar dos entrevistados que trabalharam na safra canavieira paulista (2000 - 2011). 


\section{LISTA DE MAPAS}

Mapa 1 - Localização de Timbiras na microrregião de Codó/MA ........................ 2

Mapa 2 - Localização de Guariba na microrregião de Jaboticabal e Pradópolis na microrregião de Ribeirão Preto................................................................. 3

Mapa 3 - Localização do município de Timbiras /MA …….............................. 22

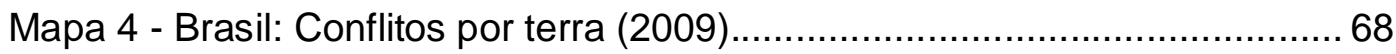

Mapa 5 - Brasil: Número de Famílias Envolvidas em Conflitos por Terra (2010).

Mapa 6 - Brasil: Número de ocorrências em conflitos por terra (2010)............70

Mapa 7 - Brasil: Sujeitos Sociais Envolvidos em Conflitos por Terra (2010).... 73

Mapa 8 - Brasil: Índice de Gini da área total dos estabelecimentos agropecuários, por município (2006)........................................................ 75

Mapa 9 - Localização do município de Pradópolis/SP.................................. 141

Mapa 10 - Fazenda Lageado - século XIX.................................................... 143

Mapa 11 - Localização do município de Guariba/SP.................................... 158

Mapa 12 - Itinerários migratórios de integrantes entrevistados da família de

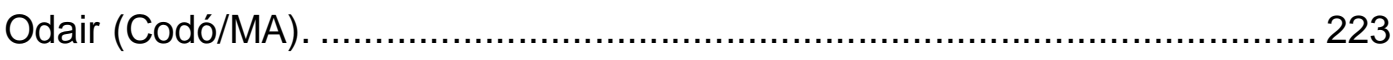

Mapa 13 - Itinerários migratórios de integrantes entrevistados da família de Francisco e Domingos (Timbiras/MA) ....................................................... 226

Mapa 14 - Itinerários migratórios de integrantes da família de Raimundo (Timbiras/MA). 233

Mapa 15 - Itinerário migratório de integrantes entrevistados da família de Jonas (Timbiras/MA) 238

Mapa 16 - Itinerário migratório de integrantes entrevistados da família de Elinaldo (Timbiras/MA). 
Mapa 17 - Itinerários migratórios de integrantes entrevistados da família de

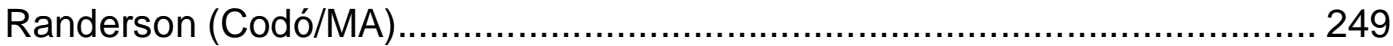




\section{SUMÁRIO}

INTRODUÇÃO 1

1 TIMBIRAS: O PROCESSO DE CONSTRUÇÃO DA TERRITORIALIDADE DE "PONTA DE RUA" E A CRIAÇÃO DOS DETERMINANTES ESTRUTURAIS DA EXPERIÊNCIA MIGRATÓRIA 20

1.1 "Viver de roça": a territorialização camponesa no município de Timbiras/MA. 20

1.2 A Territorialização do capital e dos conflitos fundiários nas terras concentradas dos babaçuais do leste maranhense

1.3 A Migração "Temporária" para os Canaviais Paulistas. 87

\section{PRADÓPOLIS E GUARIBA: O PROCESSO DE CONSTRUÇÃO DE TERRITORIALIDADES MIGRATÓRIAS DOS TRABALHADORES}

CANAVIEIROS. 101

2.1 A Territorialização da Agroindústria Canavieira no Brasil. 102

2.1.1 O contexto de expansão do agronegócio canavieiro nos anos 2000 102

2.1.2 O Acirramento da Precarização das Relações de Trabalho nos Canaviais do Nordeste Paulista

2.1.3 Os Espaços Sociais de Reprodução da Força de Trabalho Canavieira nas Cidades do Nordeste Paulista 132

2.2 Pradópolis e Guariba: o Processo de Construção de Territorialidades Migratórias dos Trabalhadores Canavieiros.

\section{IDAS E VINDAS: REDE DE RELAÇÕES PESSOAIS NA CONSTRUÇÃO} DE TERRITORIALIDADES MIGRATÓRIAS

3.1 Redes de informações que sustentam o processo migratório de famílias de trabalhadores rurais maranhenses para o labor nos canaviais paulistas 169

3.2 Redes técnicas de apoio à troca de informações que sustentam o processo migratório e as conexões entre os territórios de migração e o local de origem ... 175 
3.3 Redes de aliciamento e recrutamento construindo redes territoriais e territórios de migração 186

3.4 Itinerários migratórios de trabalhadores maranhenses: os roteiros da "precisão". 215

3.5 Itinerário migratório das famílias dos trabalhadores migrantes............ 220

3.5.1 Família de Odair (Codó/MA) ............................................ 220

3.5.2 Família de Francisco e Domingos (Timbiras/MA)......................... 224

3.5.3 Família de Raimundo (Timbiras/MA) ................................... 228

3.5.4 Família de Jonas (Timbiras/MA)........................................ 234

3.5.5 Família de Elinaldo (Timbiras/MA) ...................................... 239

3.5.6 Família de Randerson (Codó/MA) .............................................. 242

CONSIDERAÇÕES FINAIS .................................................................. 250

REFERÊNCIAS....................................................................................... 255 


\section{INTRODUÇÃO}

Este trabalho tem por objetivo compreender as redes da migração, enquanto processo social, de homens, mulheres e famílias, originários do município de Timbiras, no leste maranhense, que são convertidos em trabalhadores canavieiros para a labuta nos talhões da gramínea no Centro-Sul do país, em especial no nordeste do Estado de São Paulo, durante os anos 2000.

Redes de relações sociais são criadas, fortalecendo a construção de redes de pobreza no que chamamos de área de origem e destino migratório porque envolvem múltiplas dimensões de redes de relações sociais, que perpassam pelo âmbito familiar, dos parentes, amigos e vizinhos, aproximando no tempo territorialidades precárias, distintas, e também legitimando processos de dominação e exploração cá e lá.

Compreende-se que há uma vinculação estreita entre o processo de construção de territórios de migração e a territorialidade experimentada na área de origem, sustentada por redes múltiplas de relações sociais que cimentam estas territorialidades criadas e ressignificadas com a migração. Migração de curta ou longa distância, que, de acordo com Silva (2005, p.54), é percebida como processo social, um acontecimento histórico, que afeta os que partem, ficam, foram e irão partir, envolvendo agentes sociais, cujos familiares, no caso em tela moram no município de Timbiras, localizado, de acordo com a regionalização proposta pelo IBGE, na microrregião geográfica de Codó, na mesorregião geográfica do Leste Maranhense (Veja o Mapa 1), experimentando locais de destino nos municípios de Pradópolis e Guariba, situados, de acordo com o IBGE na microrregião geográfica de Ribeirão Preto e Jaboticabal (Observe o Mapa 2). 
Pretende-se, dessa maneira, a compreensão da migração a partir da construção/reconstrução de territorialidades precárias durante a vida destes agentes sociais, por meio de redes multifacetadas de relações sociais que criam/recriam significações e representações dessas múltiplas dimensões deste processo social.

Busca-se, por meio do conceito de territórios-rede, proposto por Costa (2004, p. 298) a interpretação das estratégias de reprodução social desses agentes sociais, a partir de migrações para o trabalho formal na safra canavieira paulista. Na concepção do autor (COSTA, 2004, p. 289, 293)," as redes, em diferentes níveis, precisam se territorializar, ou seja, necessitam da apropriação e delimitação de territórios para a sua atuação, e é constituída de elementos que se diferenciam ao longo do tempo".

Desse modo, as migrações consideradas temporárias, pelo autor constituem "um componente muito importante na conformação de sua identidade ou na fragilização de sua identidade" (COSTA, 2004, p. 301), pois o "território também é produzido no movimento ou, pelo menos, na repetição do movimento, no controle por redes (território-rede) promovendo uma rearticulação de limites, e intensificando uma certa hibridização cultural".

Pensamos que a construção de redes multifacetadas de relações sociais, que configuram territorialidades precárias no Maranhão e em São Paulo, permite dar um significado geográfico, para um conjunto de interações territoriais carregadas de conteúdo simbólico e cultural, tão presente nas reflexões elaboradas no âmbito da Antropologia ou da Sociologia.

Para Costa (2004, p. 306), os territórios-rede são um dos três tipos ideais em relação às formas de organização espaço-territorial. Os outros dois são o território-zona e o que designa como aglomerados humanos de exclusão. De acordo com o autor, os territórios-rede "são configurados, sobretudo na topologia ou lógica das redes, são espacialmente descontínuos, dinâmicos (com diversos graus de mobilidade) e mais suscetíveis a sobreposições”. Em nosso estudo, compreende a construção de ou uma rede canavieira, isto é, uma rede de produção de movimentos, que se estende de Timbiras até Pradópolis e Guariba. 
Contudo, antes de revelar a importância do conceito de território em Costa (2004) para o desenvolvimento deste trabalho, temos que considerar a sua concepção.

Para Costa (2011, p. 120), o território:

(...) é o produto de uma relação desigual de forças, envolvendo o domínio ou controle político-econômico do espaço e sua apropriação simbólica, ora conjugado e mutuamente reforçado, ora desconectado e contraditoriamente articulado.

É a partir desta visão integradora de território, que compartilha diferentes dimensões - como a política, a econômica e a cultural - e escalas, é que faz sentido o termo rede, que possibilita uma compreensão de forma articulada entre diferentes territorialidades e suas organizações internas.

Desse modo, a partir da mediação dos conceitos de Costa $(2004,2011)$ acerca do conceito geográfico de território e de redes, e suas discussões em torno das proposições ideais de organização espaço-territorial assentadas nas representações de território-zona, território-rede e aglomerados humanos de exclusão é que podemos pensar na criação de redes entre as territorialidades migratórias precárias experimentadas no município de Timbiras, no leste maranhense, e nas cidades de Pradópolis e Guariba, no nordeste do Estado de São Paulo.

Segundo o geógrafo suíço Claude Raffestin (1993, p. 158), a territorialidade:

reflete a multidimensionalidade do "vivido" territorial pelos membros de uma coletividade, pelas sociedades em geral. Os homens "vivem", ao mesmo tempo, o processo territorial e o produto territorial, por intermédio de um sistema de relações existenciais e/ou produtivistas. Quer se trate de relações existenciais ou produtivistas, todas são relações de poder, visto que há interação entre os atores que procuram modificar tanto as relações com a natureza como as relações sociais.

Mais adiante, o mesmo autor aponta que: "A territorialidade se manifesta em todas as escalas espaciais e sociais; ela é consubstancial a todas as relações 
e seria possível dizer que, de certa forma, é a "face vivida" da "face agida" do poder" (RAFFESTIN, 1993, P. 161-162).

A colocação de Raffestin traz para discussão a concepção da construção de territórios como uma prática social, assentada, sobretudo, na relação de poder, na experiência humana do território, (re)criada a partir do jogo e da disputa de forças entre grupos sociais.

Já Saquet (2007, p.129), em uma trajetória distinta, pondera que a territorialidade significa "as relações diárias, momentâneas, que os homens mantém entre si, com sua natureza interior e com sua natureza inorgânica, para sobreviverem biológica e socialmente", na qual é

resultado e determinante do processo de produção de cada território, de cada lugar; é multipla, e por isso, os territórios também o são, revelando a complexidade social e, ao mesmo tempo, as relações de dominação de indivíduos ou grupos sociais com uma parcela do espaço geográfico, outros indivíduos, objetos, relações.

Mais adiante Saquet (2007, p. 129) indica que "o território é compreendido, antes de qualquer 'coisa', como um espaço de organização e luta, de vivência da cidadania e do caráter participativo do diferente e do desigual".

Dentro desta perspectiva, as considerações de Raffestin (1993), Costa (2004, 2011) e Saquet (2007), acerca dos conceitos de território e territorialidade, apontam o significado dos conflitos que arrolam no cotidiano e a disputa pela organização dos espaços de vida humanos em múltiplas esferas (social, econômica, política, cultural e simbólica.

Em suma, uma questão se coloca: Em que sentido, redes de relações sociais que se intensificaram com as migrações para o trabalho nas atividades da agricultura canavieira no nordeste paulista, desde o final da década de 1990, afetaram o processo de reprodução social de famílias, de origem camponesa do município de Timbiras, no leste maranhense?

Para buscarmos aproximações ao entendimento da realidade social ressignificada pelas migrações, apoiaremo - no em um enfoque dos estudos migratórios que não se fundamenta em uma interpretação neoclássica de migração, que se baseia na proporção dos fluxos de população entre as regiões 
de origem e destino, a partir de uma necessidade racional do mercado capitalista, desprezando a dimensão histórica das migrações (PÓVOA, NETO, 2007, p. 49), ou em uma tendência histórico-estruturalista assentada em uma "percepção de processos gerais, dentro dos quais, a migração ganha sentido e tende a assumir um papel, reduzindo a importância das histórias individuais e das singularidades desse processo migratório" (PÓVOA, NETO, 2007, p. 50).

Apoiaremo-nos em Silva (2005, p. 53 - 54), que aponta a centralidade da categoria trabalho, em torno das diversas linhas interpretativas sobre migrações. Segundo a autora, as migrações podem ser compreendidas como um processo social e histórico e os migrantes como agentes desse processo:

Em vez dos modelos de deslocamento da população, sugere-se a análise da migração enquanto acontecimento histórico que atinge os que partem e os que ficam, construído por elementos objetivos, estruturais, ideológicos, culturais e subjetivos, visto sob a ótica das organizações sociais, de classe, gênero e raça/etnia. (SILVA, 2005, p. 54)

Pretende-se, dessa maneira, compreender o processo migratório a partir da construção de territorialidades precárias, sustentadas por redes multifacetadas de relações sociais. Redes de aliciamento, deslocamento, informações, técnicas conferem uma nova relação entre campo e cidade. A territorialidade de "ponta de rua" expressa uma prática diária de negação e luta diante do processo de empobrecimento que acompanha a história das famílias dos trabalhadores migrantes, e não uma marca espacial da expropriação camponesa.

Aproximamo -nos, portanto das considerações de Suzuki ( 2007, p. 93) que lembra-nos que o processo de modernização não pode ser pensado única e exclusivamente a partir das lentes do território do capital, mas a partir das relações construídas e ressignificadas na reprodução das relações sociais.

No campo e na cidade, vão se construindo territórios do capital, mas sem destruir todas as formas pré-existentes que, ao seu metamorfosearem, encontram maneiras de resistirem e persistirem, enquanto outras são criadas. Vale, aqui, lembrar, no campo, a existência dos caiçaras, dos quilombolas, das populações ribeirinhas, dos faxinalenses, dos ocupantes de fundos de pastos, das populações 
indígenas, dentre múltiplas possibilidades de resistência e de criação de formas sociais que se conformam em territórios que negam o território do capital, marcado pela lógica da modernização no sentido da constituição de uma nova relação entre o campo e a cidade, no mundo da modernidade e do moderno.

Com isto, o processo de modernização no império do agronegócio tem também o seu alcance em Timbiras, e o mesmo nas cidades paulistas.

A escolha de Pradópolis e Guariba, como áreas de migração a serem analisadas nesta pesquisa pautou-se em levantamento preliminar, ancorado em relatos orais obtidos junto ao coordenador da Comissão Pastoral da Terra (CPT), em Codó e Serviço Pastoral do Migrante (SPM), em Guariba, agentes de pastorais sociais em Timbiras, e de testemunhos orais colhidos em atividade de campo realizada em janeiro de 2010, nos municípios de Timbiras e Codó.

Nesse período, artigos publicados por Alves (2006, 2007), Novaes (2007), Silva (2006a, 2006b, 2007b), além de informações e acompanhamentos promovidos pelo Serviço Pastoral do Migrante de Guariba apontavam uma mudança na composição e predomínio do trabalho migrante para os canaviais paulistas e do Centro-Sul do país, processo relacionado à intensificação do ritmo de produtividade do trabalho, requerido pelas unidades agroindustriais processadoras da gramínea, que provocou a morte de vinte e um cortadores de cana entre os anos de 2004 e 2009, além da multiplicação de casos de mutilações no corpo de canavieiros, provocadas pelo excesso de trabalho no eito dos canaviais. Estas ocorrências envolviam, em sua maioria, trabalhadores migrantes, dois deles originários de Codó, município limítrofe de Timbiras, no Maranhão.

A partir das denúncias feitas a Pastoral do Migrante e dos autores supracitados, os trabalhos de Andrade (2003), Rumin (2004), documentários e notícias veiculadas na imprensa alternativa (Brasil de Fato) ou em ONGs (Repórter Brasil e Rede Social de Justiça e Direitos Humanos) e na dita grande imprensa escrita e audiovisual oferecendo um maior alcance da "face perversa da produção canavieira do país", contraposta ao apelo midiático massivo e sustentado por autores de inúmeras instituições de pesquisa e agências governamentais. Estes últimos proclamam a importância do etanol e da expansão 
canavieira no Brasil diante dos desafios globais para a diminuição dos lançamentos de gases estufas oriundos da queima de combustíveis fósseis, preconizado por grandes encontros internacionais patrocinados por organismos multilaterais para reduzir o efeito acentuado das mudanças climáticas que alegavam/alegam ocorrer no planeta. No entanto, estes agentes e instituições não se manifestam sobre as condições subumanas de trabalho, nas quais estão envolvidos centenas de milhares de pessoas. Esse discurso ainda foi assumido por representantes que defendiam o agronegócio, como forma de desenvolvimento econômico e social no campo, de acordo com Bezerra (2009, p. 123), uma ideologia instrumentalizada posta para a sociedade brasileira.

Em 2007, a publicação organizada por José Roberto Novaes e Francisco Alves, trouxe um amplo panorama da intensificação e precarização do trabalho e da vida de milhares de homens, mulheres e famílias, que de uma forma ascendente deixavam seus Estados de origem - principalmente os situados na macrorregião Nordeste, como Maranhão, Piauí e Paraíba - para trabalhar nas atividades da agricultura canavieira no Centro-Sul do país, especialmente durante a colheita da gramínea, realizada, em média entre os meses de abril e dezembro de cada ano. Por meio do livro, análises sobre estas temáticas, foram reunidas em um esforço de integrar o conhecimento que estava sendo desenvolvido a partir de várias universidades públicas, dentre elas a UFRJ, UFSCar, UFMA, UFPI e UFCG, localizadas em regiões em que a migração e o trabalho nos canaviais provocavam/provocam relações em múltiplas dimensões da vida social. $O$ documentário Migrantes, produto desta iniciativa, teve uma divulgação importante no meio acadêmico, nas representações sindicais, pastorais e movimentos sociais provocando reflexões importantes sobre os custos sociais da expansão canavieira no Brasil, ao longo dos anos 2000, inclusive entre os próprios agentes sociais que experimentavam estas formas violentas de superexploração.

Nessa publicação, Silva (2007) e Carneiro et al. (2007) traziam elementos da migração maranhense para o trabalho na lavoura canavieira paulista, a partir das regiões de origem e destino desses agentes sociais. Carneiro et al. (2007, p. 215), do Departamento de Ciências Sociais, da Universidade Federal do Maranhão, revelaram, baseados em informações colhidas junto à Comissão Pastoral da Terra, em Coroatá/MA, a intensificação da migração maranhense em 
direção aos canaviais do Sudeste e Centro-Oeste do país, e em particular o registrado pela microrregião geográfica de Codó, na qual se encontra Timbiras.

Novas informações foram obtidas a partir do trabalho empírico realizado nas cidades de Codó e Timbiras, no leste maranhense e na capital do Estado. $O$ levantamento de informações iniciou-se pela cidade de Codó, por intermédio do representante municipal da Comissão Pastoral da Terra, a partir do qual foram obtidas as primeiras informações sobre a realidade agrária regional, os bairros de maior concentração das famílias de trabalhadores migrantes, as agências de viagem da cidade, e a experiência com as quebradeiras de coco babaçu. A partir da CPT foram estabelecidas as mediações com as famílias de trabalhadores migrantes na cidade de Codó.

O interesse em começar o trabalho de campo por Codó deve-se ao fato de o núcleo urbano regional abrigar diversas agências de viagem, locais onde se efetua a venda de passagens de ônibus clandestinos ( a partir de empresas de ônibus que operam irregularmente junto as agências fiscalizadoras, como a EMBRATUR) para diversos destinos de trabalho para os moradores de Codó e também de municípios vizinhos, dentre eles Timbiras, principalmente para a área canavieira paulista, mas também para municípios de Goiás e Mato Grosso, como pudemos constatar a partir dos depoimentos orais coletados em Codó e Timbiras na pesquisa de campo, realizada em janeiro de 2010.

Entre os entrevistados estavam homens e mulheres, que tinham ou tiveram integrantes do núcleo familiar envolvidos com a migração para as lides da agricultura canavieira no Centro-Sul do país, em especial no Estado de São Paulo, donos de agências de viagem e representantes dos dois sindicais locais de trabalhadores rurais (Sindicato dos Trabalhadores Rurais de Codó e o Sindicato de Trabalhadores Rurais da Agricultura Familiar de Codó). A partir daí tivemos a percepção in loco da interconexão e territorialização de múltiplas redes de relações sociais que sustentavam este processo social, seja a partir das redes espaciais e de relações sociais tecidas a partir do deslocamento destes agentes sociais para as cidades que abrigariam estes homens, mulheres e famílias nos núcleos urbanos no Estado de São Paulo, seja a partir das redes de relações sociais que configuram o aliciamento e a conversão destes agentes sociais a trabalhadores migrantes. 
Em suma, essa experiência revelou que a migração de homens, mulheres, famílias inteiras para as atividades do agronegócio canavieiro é nutrida pela territorialização de múltiplas redes de relações sociais, e que este processo social não pode ser percebido unicamente do estudo dos trabalhadores canavieiros, mas também a partir da experiência daqueles que permaneceram, como enfatiza Silva (2005, p. 54):

Dessa forma, os que partem fazem parte do conjunto dos que ficam. Partir e ficar são faces de uma mesma realidade social, que, embora dividida no espaço, acha-se unida no tempo. Tempo de partir para uns, é simultaneamente, tempo de ficar para outros. Portanto, produz-se uma simbiose entre o tempo uno, cindido em dois espaços. [grifo nosso]

Diante desta situação, estamos de acordo com as proposições de Silva (2005), de que a migração é um processo social, que só pode ser minimamente apreendido a partir do enfoque dessa experiência social desenvolvida por aqueles que ficaram, que não migraram, que já migraram ou irão migrar.

Envolve representantes do núcleo familiar, amigos, vizinhos e compadres que permaneceram em seus lugares de origem, e também daqueles que migraram, mas que não compõem diretamente a força de trabalho no eito dos canaviais, representadas principalmente por mulheres, sobretudo na condição de esposas, mães e avós, que executam as tarefas domésticas, que seriam operadas pelos canavieiros, após uma extenuante jornada de trabalho, comprometendo ainda mais as precárias condições de reprodução social destes trabalhadores, localizados principalmente nos bairros periféricos de diversas cidades do interior paulistas. Um exame acurado sobre estas questões serão tratadas no capítulo dois.

É diante deste contexto, que foi importante iniciar os primeiros contatos da pesquisa de campo em Codó, para conhecer um pouco mais a estrutura que permitia a locomoção e o recrutamento de milhares de trabalhadores, além de membros da família que "viajavam", mas que não se convertiam em canavieiros. Do mesmo modo, redes de relações sociais sustentam as pastorais sociais em uma escala local, regional e nacional, aqui representadas, sobretudo pela CPT (Coroatá e Codó/MA), Pastoral da Juventude (Timbiras/MA) e Pastoral dos 
Migrantes (Guariba/SP). Sobre a territorialização de redes multifacetadas no interior das pastorais sociais debruçaremos com maior profundidade no capítulo três.

Contudo, a primeira aproximação com o ambiente de pesquisa em Codó, se concretizou a partir do pesquisador Paulo Jeferson Pilar Araújo, doutorando do Programa de Pós Graduação em Linguística da Universidade de São Paulo. Com familiares residindo em Codó, ele não só informou as condições operacionais para a realização da pesquisa de campo na sede do município como indicou o pesquisador para o representante local da CPT (Comissão Pastoral da Terra).

Os contatos iniciais com o representante em Codó da Comissão Pastoral da Terra possibilitaram diálogos fecundos com pastorais sociais radicadas em Timbiras, que permitiram um primeiro diálogo com homens e mulheres que experimentaram a migração, deslocando-se para as atividades canavieiras, ou permanecendo no município de Timbiras. Permitiram também o acesso a informantes que foram fundamentais para 0 desenvolvimento da pesquisa, convertendo-se em auxiliares de pesquisa, apresentando o pesquisador àqueles que posteriormente contribuíram a partir de seus testemunhos orais, com a história de suas vidas e em especial a experiência de sua(s) migração(ões).

Também representou os primeiros contatos com alguns donos de agencias de viagem, homens e mulheres que deram o relato de suas experiências migratórias, em especial para os canaviais paulistas e representantes sindicais locais.

Mas ainda na cidade de Codó, depois da coleta de vários testemunhos orais de homens e mulheres que possuem integrantes da família trabalhando no corte da cana no Centro-Sul do Brasil, constatamos a experiência de moradores nas lides de outros produtos agrícolas como na colheita da batata e da cebola.

Percebemos que a migração de codoenses não se direciona para um mesmo empregador e um mesmo município, ao longo de alguns meses do ano, mas se espraia para diferentes regiões do Estado de São Paulo, abarcando, por exemplo, tanto regiões consideradas mais tradicionais no cultivo da cana-deaçúcar como o nordeste paulista, tanto em áreas onde a expansão da gramínea se deu de forma mais acentuada a partir do Programa Nacional do Álcool, no fim 
da década de 1970, ou com o crescimento das plantações do cultivo em terras utilizadas predominantemente para a pecuária de corte, no noroeste paulista.

Outrossim, colhemos informações sobre a grande inundação que ocorreu a partir de fortes chuvas entre o final de abril e as primeiras semana de maio de 2009, que atingiu duramente a bacia hidrográfica do rio Itapecuru, no leste do Maranhão. O principal veio hídrico drena a cidade, causando grandes prejuízos, sobretudo aos que habitam áreas próximas às suas margens, como os moradores do bairro São Sebastião e Olaria, em Timbiras, e o bairro São Raimundo, em Codó.

Igualmente, a importância de Codó para as manifestações da cultura afrobrasileira, experimentadas pelas comunidades quilombolas (que em muitos casos apresentam graves conflitos, a partir da delimitação de suas terras, com latifundiários, veremos com maior afinco, no capítulo um) e em povoados do interior do município, especialmente a partir dos ritos religiosos celebrados, como o terecó.

Depois de experimentar a pesquisa de campo e ter um primeiro contato no Estado do Maranhão com a área de estudo, foi realizado, a partir do representante codoense da CPT, o contato com religiosas da Ordem dos Palotinos, na cidade de Timbiras, e que atuam, por meio de pastorais sociais, como a Pastoral da Juventude.

Após a apresentação para as religiosas em Timbiras, foi combinada na igreja matriz de Timbiras após a celebração religiosa, por volta das 20 horas do domingo (10 de janeiro de 2010), uma reunião com algumas famílias que tinham parentes, familiares e amigos que trabalharam no corte de cana no Estado de São Paulo. Nessa ocasião, foi feita a apresentação do pesquisador e da pesquisa, em que algumas pessoas compartilharam publicamente, de forma breve, suas experiências com o trabalho no corte de cana em São Paulo.

O agente pastoral nos acompanhou na coleta de vários testemunhos orais no dia seguinte, a partir de endereços obtidos na conversa de domingo a noite, fornecidas por algumas pessoas e registradas no encontro.

$\mathrm{Na}$ semana seguinte, foram coletados os primeiros testemunhos orais de famílias de trabalhadores rurais que possuíam o histórico de pelo menos um integrante da família no trabalho no corte de cana em São Paulo. 
As entrevistas foram feitas na residência das famílias, envolvendo os interlocutores e alguns membros da família. Elas se alongaram pelo segundo trabalho de campo, realizado em janeiro de 2011, e foram acompanhadas pelos agentes pastorais, em Timbiras nos bairros de ponta de rua e em cinco povoados da área rural timbirense, com grande concentração de trabalhadores rurais migrantes para o corte de cana no Estado de São Paulo. Fotografias foram tiradas e o endereço ou indicações de localização dele nas cidades paulistas foram fornecidos pelos familiares.

A definição da amostra para a coleta dos testemunhos orais não seguiu parâmetros estatísticos para identificar os primeiros sujeitos sociais participantes da pesquisa, sendo que interações iniciais levaram a outros agentes sociais. A partir do momento que as informações colhidas passaram a se repetir, outros recursos metodológicos foram empregados, como o aprofundamento $e$ levantamento de outras informações obtidas a partir da leitura das entrevistas levantadas na visita anterior e obtenção de novos dados coletados a partir de entrevistas com outros membros da família.

O trabalho de campo na cidade de Timbiras, em janeiro de 2010, teve como objetivo estabelecer os primeiros contatos com as famílias dos trabalhadores migrantes e escolher os mediadores, diretamente ou indiretamente envolvidos com a CPT (Comissão Pastoral da Terra) no município.

A partir das informações coletadas, foram realizados trabalhos de campo na área canavieira paulista, a começar pelos diálogos, com o Serviço Pastoral do Migrante e, por intermédio dela, a coleta de testemunhos orais dos primeiros trabalhadores timbirenses alocados em Guariba e posteriormente em Pradópolis. A coordenadora do Serviço Pastoral do Migrante acompanhou os primeiros testemunhos colhidos em Guariba e os encontros de familiares das pessoas que havia conhecido e entrevistado no início do ano em Timbiras e Codó.

Novos entrevistados foram conhecidos e seus familiares (re)visitados em janeiro de 2011. Por sua vez, os primeiros trabalhadores migrantes identificados por familiares e amigos na primeira pesquisa de campo no Maranhão, em janeiro de 2010, foram localizados, seus testemunhos orais colhidos, redes foram construídas no processo de pesquisa, estabelecendo fios que interligavam 
famílias separadas espacialmente e azeitando também as relações entre o pesquisador e os agentes sociais cá e lá no universo da pesquisa.

No espaço social da área canavieira, a vida desses agentes sociais é impingida sob a insígnia do cortador de cana.

Vigiados no local de trabalho pelos agentes de fiscalização e controle do trabalho, representado pelo gato ou representantes dos fornecedores de cana e usineiros, esses homens e mulheres tem os seus comportamentos dominados pelo aparelho repressor da "usina", seu movimento corporal ritmado pela meta de produtividade no corte de cana, suas atitudes fiscalizadas e ameaçadas constantemente.

$\mathrm{Na}$ área canavieira, o espaço reprodutivo a partir do local onde reside na cidade também constitui uma extensão do controle objetivo e subjetivo executado pelos representantes do agronegócio canavieiro. Nesse espaço de controle dos movimentos dos corpos e das ações, o sentido da vida é abreviado à condição de um trabalhador intensamente explorado, desumanizado.

Sobre eles ainda pesam pseudo-afirmações e preconceitos sutis, porém profundos, de grupos de pessoas considerados do "lugar" ou até mesmo de "migrantes estabelecidos" ou "migrantes de outra origem regional".

Não podemos nos esquecer das trabalhadoras canavieiras sobre as quais, apesar de sofrerem numericamente uma redução na última década no trabalho na lavoura de cana-de-açúcar, recai ainda o peso do trabalho doméstico, das tarefas associadas à figura masculina que pode também ser trabalhador canavieiro, e do cuidado com os filhos, caso os possua. Esse fato é importante porque dá importância às relações de gênero nas análises sobre o trabalho nos canaviais, seja ele migrante ou não. Também não anula ou desconsidera o significado e a história da mulher nas plantações canavieiras ou reduz o seu papel a auxiliar da figura masculina, embora crie um diferencial entre aqueles que vêm com a mãe/mulher/avó ou não. Outrossim, a migração feminina atrelada a seu estado civil de casada.

Todas estas considerações se desenrolam no momento em que o pesquisador vai conversar e registrar a história dos homens e mulheres migrantes envolvidos no trabalho da cultura canavieira. As entrevistas, realizadas na residência dos trabalhadores migrantes, contaram com a participação do 
pesquisador e dos entrevistados, os testemunhos colhidos foram gravados ou escritos em caderno de campo, seguidos de documentação fotográfica, a partir da permissão dos agentes sociais.

Com isto também pretendemos romper com o procedimento metodológico dual entre uma área, considerada de origem e outra, a de destino. Os testemunhos colhidos no Estado do Maranhão e no Estado de São Paulo, muitas vezes revelaram o histórico de migrações experimentado por muitas famílias ou alguns de seus integrantes, em até três gerações. Homens, mulheres, famílias inteiras que se deslocaram de outras regiões e municípios do Estado do Maranhão, ou de Estados limítrofes, como o Piauí, Tocantins e o Ceará. Deste modo, o "ir" e "vir", a origem e destino, transformam-se conforme as gerações, e impossibilita uma leitura deste processo social a partir de um ponto fixo e estruturante de origem e destino.

A migração experimentada configura territórios de migração, territorialidades experimentadas e que ressignificam as relações com 0 dito ambiente de partida e com aqueles que ficaram. Da mesma forma os espaços sociais do deslocamento, seja de longa ou curta distância são importantes na (re)criação de representações, conformação de territorialidades nas áreas de migração e de novos significados nutridos com o Estado do Maranhão. A saga, os riscos da travessia por diversos Estados do país, a partir dos ônibus clandestinos, os pontos de longa parada ou de quebra dos ônibus são expressos espacialmente, e suas experiências relembradas, tanto individual como socialmente.

A pesquisa de campo se estendeu para Guariba em julho e agosto de 2011, a partir de contatos iniciais indicados pela Pastoral do Migrante e dos apontados pelos entrevistados em Timbiras, em janeiro de 2010 e 2011.

Em Guariba, o presidente dos Sindicatos dos Empregados Rurais Assalariados forneceu a história da representação sindical local e informações sobre as condições de trabalho e dados sobre a atividade na agricultura canavieira. Foi também verificada, junto ao sindicalista, a possibilidade de observação direta no local de trabalho destes agentes sociais, nos talhões de cana. Em agosto, foi realizado, por meio do Serviço Pastoral do Migrante um 
encontro com os migrantes, na comunidade Cristo Rei, em que o pesquisador pode falar sobre sua pesquisa e conversar com mais trabalhadores migrantes.

A próxima etapa desenvolveu-se em Pradópolis, sem a participação de informantes ou intermediação de pastorais sociais, como aconteceu em Timbiras e Guariba, mas a partir de referências de familiares obtidas nos trabalhos de campo de janeiro de 2010 e 2011. Além desses contatos prévios, momentos inesperados ocorreram, e abrangeram também comerciantes timbirenses na cidade, e até a passagem fulminante de um ônibus clandestino durante o fim da noite por Pradópolis, e experiência familiar de luta pela terra que permitiram a territorialização camponesa de familiares no Projeto de Assentamento da CIT, em Timbiras, e de um ex-cortador de cana, mutilado pelo trabalho penoso nos canaviais, e integrante do assentamento Horto Guarani, em Pradópolis.

Desta sorte, por meio de entrevistas de homens, mulheres e famílias que experimentam/experimentaram a migração para o trabalho na agricultura canavieira no Estado de São Paulo, no município maranhense e nas cidades paulistas, a partir do emprego da história oral como método de pesquisa, procuramos vislumbrar nas idas e vindas desses agentes sociais o significado deste processo para as múltiplas territorialidades construídas aproximando espaços sociais a partir de redes multifacetadas de relações sociais.

Já os relatos orais se estenderam a dirigentes sindicais do município de Codó (Sindicato dos Trabalhadores Rurais de Codó e Sindicato dos Trabalhadores da Agricultura Familiar de Codó), a partir dos quais pretendíamos levantar informações acerca das atividades agrárias do município, de sua relação com a migração para os canaviais do Centro-Sul e dados pertinentes à organização fundiária, aos conflitos no campo e à resistência, a partir da luta pela terra nos municípios de Codó e Timbiras.

Quanto à busca de dados, relativos à produção sucroalcooleira do Brasil, do Estado de São Paulo e das usinas que empregavam trabalhadores timbirenses alocados em Guariba e Pradópolis no Estado de São Paulo, foram importantes os dados disponíveis no sítio da UNICA (União da Indústria de Cana de Açúcar) até a safra 2008/2009, complementados com informações levantadas em publicações do setor, como o Anuário da Cana consultadas nas bibliotecas do IBGE e do Instituto de Economia Agrícola (IEA), no município de São Paulo. Referências 
relativas aos veículos emplacados em Timbiras foram buscadas no sítio do DENATRAN (Departamento Nacional de Trânsito) e são importantes para evidenciar o crescimento de motocicletas, uma das principais mercadorias conseguida a duras penas e obtida, principalmente por homens, por meio dos trabalhos nos canaviais.

Publicações referentes ao município de Timbiras, à região dos Cocais e a estrutura agrária do Maranhão foram encontradas por meio de consulta a biblioteca do Programa de Pós-Graduação em Políticas Públicas da UFMA, da coleção Maranhão da Biblioteca Central da UFMA e de indicações bibliográficas fornecidas pelo professor Marcelo Carneiro, durante a pesquisa de campo em janeiro de 2010.

Foi importante reconstituir uma base histórica dos determinantes estruturais estreitamente relacionados à migração de homens, mulheres e famílias para cidades paulistas, em razão do trabalho nas plantações de cana-deaçúcar, e para a qual reportamo-nos às origens de sua intensificação, na última década do século XX. Assim, iremos explicitar porque a migração destes agentes sociais está associada a experiências migratórias, ensaiadas por suas famílias no passado, processo social intensificado com a degradação crescente das condições de reprodução social como camponeses em suas regiões de origem, sobretudo do Piauí e Ceará.

A economia de Timbiras assentada na sua produção agrícola, em especial a partir da coleta e beneficiamento de subprodutos do coco babaçu e seus arranjos territoriais, obedece aos ditames do processo de modernização maranhense apregoado pela lei de terras de 1969.

A população do município, que morava no interior dos latifúndios, que se apoderou e recriou terras de trabalho por meio de suas posses e aqueles que eram proprietários de pequenas extensões de terra foi violentamente expropriada, expulsa, especialmente a partir da década de 1970, configurando a construção de territorialidades precárias, chamadas localmente de bairros de "ponta de rua" no núcleo urbano de Timbiras. E mais, a falta de oportunidades de emprego no âmbito da economia urbana local e regional e a ineficiência do poder público em garantir possibilidades reais de reprodução social para os moradores do município intensificam a situação de precariedade e de vulnerabilidade de milhares de 
pessoas convertidas forçosamente a canavieiros, cortadores de cana, força e energia consumidas no processo de trabalho para mover as engrenagens do capital sucroalcooleiro no Estado de São Paulo. São esses os principais pontos que discutiremos no capítulo um.

No segundo capítulo do trabalho, discutiremos os principais elementos associados à agricultura canavieira nos municípios de Guariba e Pradópolis, e acontecimentos relacionados à sua formação sócio-histórica, convertendo-as em importantes núcleos urbanos que alocam diferentes territorialidades migratórias,

Em um terceiro capítulo, discorreremos sobre o processo de construção de territorialidades migratórias e das múltiplas relações entre os territórios precários criados entre Timbiras e Pradópolis e Guariba, para, posteriormente, particularizarmos as implicações sociais deste processo para os agentes que experimentam e recriam essas redes multifacetadas. Para finalizar o capítulo apresentaremos as experiências migratórias de oito famílias selecionadas, pela importância e intensidade que as migrações apresentam nas suas histórias de luta e re(existência) contra $\circ$ acirramento das condições de pobreza que persistem em suas vidas. 


\section{TIMBIRAS: O PROCESSO DE CONSTRUÇÃO DA TERRITORIALIDADE DE “PONTA DE RUA” E A CRIAÇÃO DOS DETERMINANTES ESTRUTURAIS DA EXPERIÊNCIA MIGRATÓRIA}

\section{1 "Viver de roça": a territorialização camponesa no município de Timbiras/MA}

O município de Timbiras situa-se no leste do Estado do Maranhão, compondo de acordo com a classificação regional do IBGE, a mesorregião geográfica do Leste maranhense, e de forma mais detida a microrregião geográfica de Codó1. Estende-se ${ }^{2}$ por $1486,58 \mathrm{Km}^{2}$, e apresentou no último censo demográfico nacional em 2010, 28.007 habitantes. Segundo a GEPLAN (Gerência de Estado de Planejamento e Desenvolvimento Econômico), responsável pelo Zoneamento Econômico Ecológico do Estado do Maranhão, em 2000, Timbiras localiza-se na região de Codó $^{3}$, região que integra outra, de dimensões mais amplas, conhecida no contexto estadual como região dos Cocais.

Timbiras encontra-se a 316 quilômetros da capital estadual. Do ponto de vista físico, localiza-se em uma região de bioma de transição para as florestas úmidas da Amazônia Oriental, e se destaca, nos dias de hoje, por ser o ponto de origem da maior parte das migrações sazonais do Estado do Maranhão em direção aos municípios canavieiros paulistas.

Esta região foi importante produtora de algodão, ao longo do século XIX, e a pioneira na acolhida de um consistente fluxo demográfico oriundo de outros Estados que compõe a atual região Nordeste, constituído, sobretudo por

1 Fonte: 1. Atlas Nacional do Brasil Milton Santos. Rio de Janeiro: IBGE, 2010, p. 55 - 56.

2. SIDRA/IBGE. Disponível em: http://www.sidra.ibge.gov.br Acesso em 19 Jul. 2009.

2 De acordo com informação colhida no sítio do IBGE.

Disponível em: http://www.ibge.gov.br Acesso em 21 Nov. 2011

${ }^{3}$ A região de Codó, proposta pela GEPLAN, segundo o Zoneamento Ecológico-Econômico de 2000, difere da microrregião de Codó, criada pelo IBGE, apenas pelo acréscimo do município de São Mateus do Maranhão.

Fonte: ZEEMA (Zoneamento Ecológico- Econômico do Estado do Maranhão).

Disponível em: http://www.zee.ma.gov.br/icon/mapas/m_codo.gif Acesso em 19 Jul. 2010. 
cearenses e piauienses que ocupavam a região das depressões interplanálticas do Sertão, dominadas pela caatinga, e impingidas por uma elevada concentração fundiária (FERREIRA, 2010, p. 1; LACERDA, 1983, p. 149). O leste maranhense, ao contrário, concentra grandes áreas ocupadas, do ponto de vista fitogeográfico, pelo babaçu, "palmeira sagrada", cuja extração e quebra do coco oferece uma complementação econômica à agricultura camponesa regional (MAY,1990), com a extração principalmente da amêndoa, utilizada para a produção de óleo de babaçu, de grande importância histórica para a economia estadual ${ }^{4}$ (ANDRADE, 2005, p. 232; VALVERDE, 1957,p. 392, 396-398 ). A microrregião geográfica de Codó é drenada por cursos 'água, que compõe a bacia hidrográfica de importantes canais fluviais do Estado: o Itapecuru, dominante em sua porção ocidental e meridional - cujo leito se estende aproximadamente por 1.050 quilômetros em todo o Estado (IBGE, 1998, p. 13) - e o Munin, na porção centronorte da referida região. O núcleo urbano de Timbiras é drenado pelo rio Itapecuru, e seus afluentes (IBGE, 1998, p. 17), embora a maior parte da área municipal - regiões central norte e leste - sejam drenadas por veios hídricos pertencentes à bacia hidrográfica do Munin, com destaque para o rio Iguará (IBGE, Mapa Estatístico Municipal de Timbiras, 2007). Observe o Mapa 3 na página seguinte.

O décimo quinto volume da Enciclopédia dos Municípios Brasileiros (IBGE, 1959 , p. 363) indica a presença de famílias de agricultores portugueses, nas primeiras décadas do século XIX, ocupando terras que compõem, nos dias de hoje, o município de Timbiras. O povoado de Urubu, nome inicial da aglomeração humana que deu origem ao núcleo urbano mudou de denominação, entre os anos de 1895 e 1900, em razão da penetração de frades capuchinhos que considerando o antigo nome do povoado sem significação, passaram a designá-lo como Monte Alegre, incorporado a área municipal de Codó.

\footnotetext{
${ }^{4}$ Cerca de 400 mil extrativistas trabalham na coleta e quebra artesanal do babaçu no Maranhão, principalmente, nas regiões do Médio Mearim, Cocais, Pré-Amazônia e Cerrado Maranhense (ALMEIDA, 2005, p. 42).
} 
LOCALIZAÇÃO DO MUNICÍPIO DE TIMBIRAS

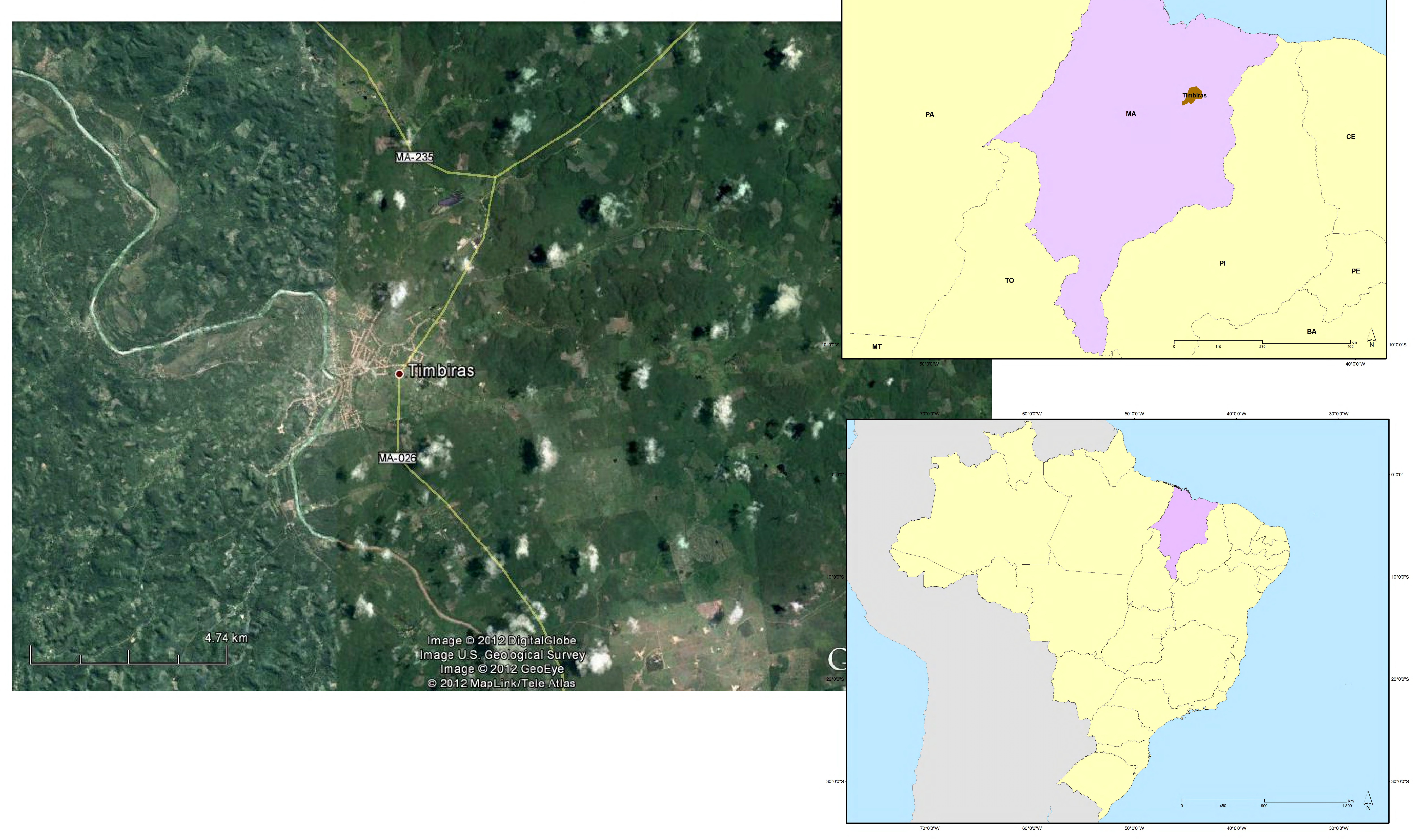


A lei estadual $\mathrm{N}^{\circ}$. 21 de 5 de abril de 1920, cria o município de Monte Alegre, desmembrado de Codó, e limitado ao norte pelo município de Vargem Grande, a nordeste e a leste com o município de Chapadinha, ao sul e a sudeste com o município de Codó,e ao sul, sudoeste e noroeste com o município de Coroatá. Todos os municípios vizinhos de Monte Alegre já tinham sido criados, e, portanto os limites municipais coincidem com os do atual município de Timbiras.

Em 30 de dezembro de 1943, por meio do Decreto-Lei $\mathrm{N}^{0}$. 820, que estabeleceu uma nova divisão administrativa e judiciária do Estado, o topônimo do município foi mudado para Timbiras, em alusão a passagem pela região de povos indígena timbira ${ }^{5}$.

O município é cortado pelos trilhos da antiga Estrada de Ferro São LuísTeresina, construída com a intenção de facilitar o escoamento da produção têxtil da bacia do rio Itapecuru. FERREIRA (2008, p. 118) aponta que a instalação da ferrovia deveu-se, sobretudo, a problemas administrativos e operacionais, que culminaram com a intensificação do processo de assoreamento do rio Itapecuru, por parte da Companhia de Navegação a Vapor do Maranhão, até então o principal meio de escoamento de produtos têxteis, concentrada na região. A partir daí foram retomados os projetos de construção de uma estrada de ferro, cujo primeiro trecho foi inaugurado em 1895, ligando a cidade de Caxias até a sede do município de São João das Cajazeiras (atual cidade de Timon) com 78 quilômetros, que posteriormente foi acrescido, em 1921, de um trecho interligando as cidades de São Luís a Caxias medindo 372 quilômetros. Em 1938, foram adicionados mais dois quilômetros, conectando Timon, no Estado do Maranhão a cidade vizinha de Teresina (PI), na margem direita do rio Parnaíba, totalizando os 452 quilômetros de ferrovia que passa a ser chamada então de Estrada de Ferro São Luís-Teresina (FERREIRA, 2008, p. 118 - 119, 123).

\footnotetext{
${ }^{5}$ Os grupos timbira se localizam no sul do Maranhão, leste do Pará e norte de Tocantins. Os que estão mais para sudeste, habitam uma área relativamente plana, interrompida por morros de paredes verticais e cimos chatos, muitas vezes escalonados, coberta pelo cerrado, cortado por cursos d'água ao longo dos quais se estendem matas ciliares. Os situados mais para noroeste ficam na transição do cerrado para a floresta amazônica, como os Apinayé, Pukobyê, Krinkatí, Kukoikateyê, ou já dentro desta, como os Gaviões do Oeste e os Krenyê.

Fonte: http://pib.socioambiental.org/pt/povo/timbira/1820 Acesso em 30 Set 2011
} 
Na ferrovia a indústria têxtil, apoiada nas plantações de algodão da região, faz a pujança das cidades de Codó, e principalmente de Caxias no baixo Itapecuru, como indica Mattos (1950, p. 50):

Sua origem remonta aos fins do século passado e deve-se ao espírito empreendedor de um caxiense, o eminente homem público Francisco Dias Carneiro. A primeira fábrica de tecidos do Estado foi instalada em Caxias, em 1887. (...) Conta, ainda, a zona do Itapecuru, com uma fábrica de tecidos em Codó.

O surto da indústria têxtil, concentrada na bacia do Itapecuru, não tardou a malograr, em razão da abolição da escravatura, a retomada do controle estadunidense e inglês do mercado internacional da malvácea e também da pressão da indústria têxtil paulista, alicerçada por meio da reinversão do capital acumulado com a exportação de café e apoiada na força de trabalho imigrante (FERREIRA, 2008, p. 119).

Contudo, a estação Timbiras da Estrada de Ferro foi inaugurada em $1920^{6}$, como parte integrante do trecho ferroviário entre São Luís e Caxias, em 1921, conforme indicou Ferreira (2008, p. 118). Veja a Figura 1:

\footnotetext{
${ }^{6}$ Fonte: http://www.estacoesferroviarias.com.br/ma-pi/timbiras.htm Acesso em 21 Nov. 2011.
} 


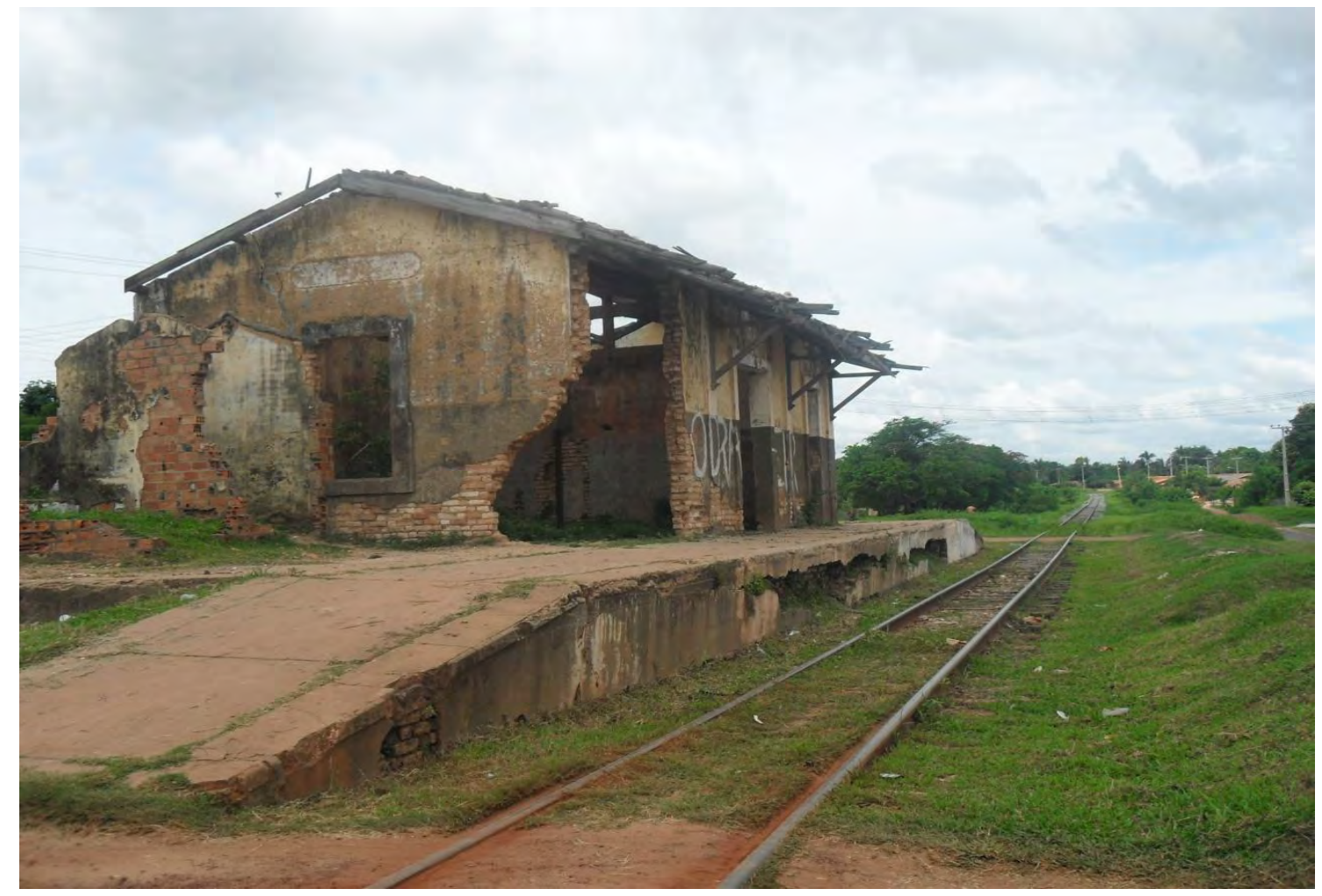

Figura 1 - Velhos caminhos de trem. Estação abandonada da antiga ferrovia São Luís - Teresina que passa pelo município de Timbiras, e divide o bairro São Sebastião no núcleo urbano.

Foto do autor. 19 de Janeiro de 2011

A decadência do transporte ferroviário no Vale do Itapecuru, no leste maranhense reflete também o declínio da indústria têxtil e a produção de algodão regional, sobretudo a partir dos municípios de Codó, e principalmente Caxias.

Passageiros circularam pela ferrovia até 1991 e cargueiros movem-se pela estrada de ferro até os dias de hoje. A estação encontra-se abandonada, e os trilhos servem de limite entre a porção mais elevada, designada localmente como bairro Alto, e a menos elevada do bairro São Sebastião. A ferrovia fez parte da Rede Ferroviária Federal S.A. (R.F.F.S.A) entre 1975 e 1997, e foi concedida desde então à Companhia Ferroviária do Nordeste ${ }^{7}$, por meio de leilão realizado em 18 de julho de 1997 desde 2007 (FERREIRA, 2008, p. 210).

Em 1966, José Ribamar Ferreira de Araújo Costa (apelidado de Zé do Sarney, e mais tarde, José Sarney) torna-se governador do Maranhão, e empreende dentro de sua política de modernização capitalista "um audacioso

\footnotetext{
${ }^{7}$ Fonte: http://www.antt.gov.br/relatorios/ferroviario/concessionarias2002/15-CFN.pdf Acesso em 30 Set. 2011
} 
projeto de construção de estradas que cortaram o Estado, ligando-o às capitais vizinhas e às regiões produtoras (Aragão, 2009, p. 40).

Se o início da história do município de Timbiras também é marcada pela construção da estação ferroviária no diminuto núcleo urbano e dos trilhos pela área municipal, posteriormente, o principal meio de locomoção para as cidades vizinhas e outras regiões passa a ser as rodovias. A sede do município passa a ser interligados por rodovia (MA 026) ao núcleo urbano vizinho de Codó, distante 25 quilômetros da cidade de Timbiras, e a MA 235 que possibilita os contatos com a sede municipal de Coroatá, há 36 quilômetros da área urbana timbirense. A MA 026 conecta também a cidade de Timbiras, com a BR 316 (Teresina-Belém), traçada entre 1959-1960, por meio do município de Codó. A cidade de Timbiras apresenta em virtude da proximidade geográfica ligações econômicas e comerciais mais intensas com a capital piauiense do que com São Luís.

A rodovia MA 026, no trecho referenciado foi muitas vezes na imprensa local e regional pela precariedade nas condições de manutenção do asfalto, especialmente no período de concentração das chuvas, entre dezembro e maio e também por inúmeros acidentes de trânsito e, recentemente roubo de motocicletas. Observe a Figura 2: 


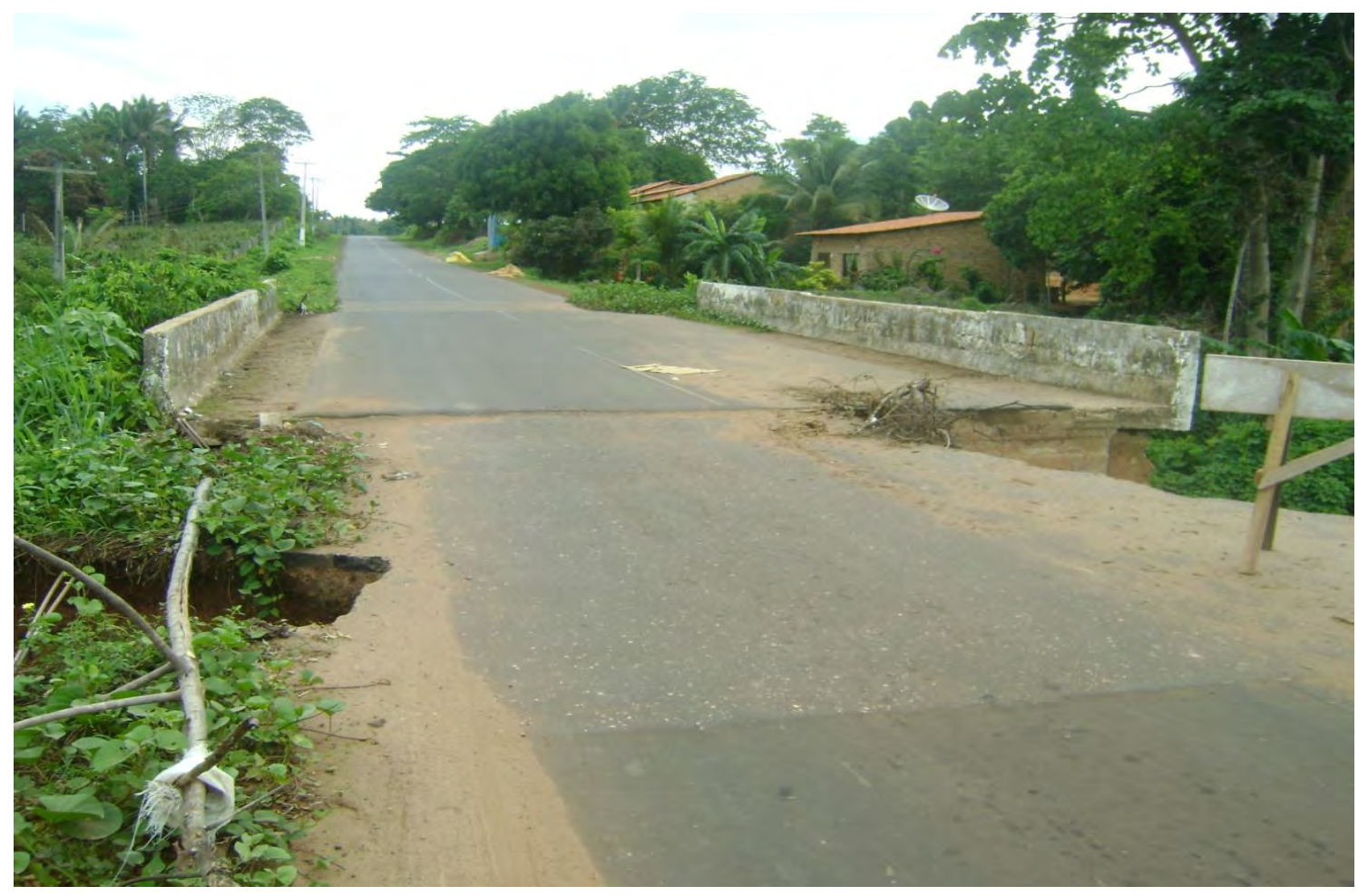

Figura 2 - A ponte para cair. Destruição da estrutura de ponte na rodovia MA 235 nas proximidades do núcleo urbano de Coroatá/MA em razão das fortes chuvas que provocaram inundações na bacia hidrográfica do rio Itapecuru, no Estado do Maranhão, entre o final de abril e início de maio de 2009.

Foto do autor, 10 de Janeiro de 2011.

Por meio da Figura 2, nota-se o estado precário da pavimentação asfáltica e da conservação de pontes, em decorrência das fortes chuvas e inundação do Baixo Itapecuru, ocorrida sete meses antes, em maio de 2009. A rodovia é passagem obrigatória dos ônibus que vão e vem com trabalhadores migrantes de ou para o município de Coroatá/MA.

Já os povoados situados no interior de Timbiras são interligados à sede municipal por várias estradas não pavimentadas, de difícil tráfego durante o período anual em que se concentram as chuvas, favorecendo a locomoção e o trânsito por elas a partir de motocicletas.

As motocicletas, adquiridas, na maior parte das vezes, por meio do ganho obtido durante a experiência migratória, sobretudo a partir do trabalho na lavoura canavieira paulista teve um crescimento exponencial em Timbiras, na medida em que intensificou a migração de timbirenses para exercer esse tipo de atividade econômica no Estado de São Paulo. Veja a participação das motocicletas no 
conjunto dos veículos emplacados no referido município timbirense, por meio da Tabela 1:

Tabela 1 - Timbiras/MA: Frota total e principais tipos de veículos emplacados (2001 - 2011).

\begin{tabular}{|c|c|c|c|c|c|c|c|}
\hline \multirow{2}{*}{ Ano } & \multicolumn{2}{|c|}{ Motocicleta } & \multicolumn{2}{|c|}{ Motoneta } & \multicolumn{2}{|c|}{ Automóvel } & \multirow[b]{2}{*}{$\begin{array}{l}\text { Total de } \\
\text { Veículos }\end{array}$} \\
\hline & Total & Em \% & Total & Em \% & Total & Em \% & \\
\hline 2001 & 95 & 54,3 & 17 & 9,7 & 33 & 18,9 & 175 \\
\hline 2002 & 148 & 58,7 & 35 & 13,9 & 36 & 14,3 & 252 \\
\hline 2003 & 193 & 60,3 & 54 & 16,9 & 39 & 12,2 & 320 \\
\hline 2004 & 232 & 60,4 & 65 & 17 & 51 & 13,3 & 384 \\
\hline 2005 & 285 & 63,9 & 72 & 16,1 & 50 & 11,2 & 446 \\
\hline 2006 & 379 & 65,6 & 94 & 16,3 & 60 & 10,4 & 578 \\
\hline 2007 & 479 & 66,5 & 112 & 15,6 & 78 & 10,8 & 720 \\
\hline 2008 & 548 & 68,2 & 114 & 14,2 & 88 & 11 & 803 \\
\hline 2009 & 705 & 70,6 & 128 & 12,8 & 92 & 9,2 & 998 \\
\hline 2010 & 871 & 70,5 & 162 & 13,1 & 124 & 10 & 1236 \\
\hline 2011 & 1065 & 71,6 & 193 & 13 & 146 & 9,8 & 1487 \\
\hline
\end{tabular}

Fonte: Sistema de Registro Nacional/ de Veículos Automotores - RENAVAN IDETRAN. Observação: Os dados referentes aos anos de 2003, 2004, 2007, 2009 e 2010 referem-se ao mês de dezembro dos respectivos anos. Devido a indisponibilidade dos dados referentes a dezembro no sítio do DENATRAN, as informações associadas a 2006 e 2008 fazem alusão ao mês de novembro, e 2005 e 2011 são referidas a setembro.

O crescimento absoluto de motonetas, e principalmente motocicletas emplacadas no município de Timbiras, foi significativo entre 2001 e 2011, período de intensa migração de trabalhadores migrantes que residem no município para o trabalho nos canaviais paulistas. As motocicletas sempre representaram no período, a maior parte dos veículos motorizados emplacados que circulavam no município, sendo 95 , em 2001 , o que respondia ar $54,3 \%$ do total de veículos emplacados, e 1065, em 2011, equivalendo a $71,6 \%$ do total de veículos motorizados com a placa do município maranhense. A variação anual e relativa do total de motocicletas emplacadas pode ser verificada por meio da Tabela 2. 
Tabela 2 - Timbiras/MA: Frota total, crescimento absoluto e relativo de motocicletas emplacadas (2001 - 2011).

\begin{tabular}{|c|c|c|c|}
\hline Ano & $\begin{array}{c}\text { Total de } \\
\text { motocicletas }\end{array}$ & $\begin{array}{c}\text { Acréscimo anual } \\
\text { (em unidades) }\end{array}$ & $\begin{array}{c}\text { Variação Relativa } \\
\text { (em \%) }\end{array}$ \\
\hline 2001 & 95 & - & 55,8 \\
\hline 2002 & 148 & 53 & 30,4 \\
\hline 2003 & 193 & 45 & 20,2 \\
\hline 2004 & 232 & 39 & 22,8 \\
\hline 2005 & 285 & 53 & 33 \\
\hline 2006 & 379 & 94 & 26,4 \\
\hline 2007 & 479 & 100 & 28,6 \\
\hline 2008 & 548 & 69 & 23,5 \\
\hline 2009 & 705 & 157 & 23,7 \\
\hline 2010 & 871 & 166 & $1.121,1 \%$ \\
\hline 2011 & 1065 & 194 & 970 \\
\hline $2001-2011$ & & & -14 \\
\hline
\end{tabular}

Fonte: Sistema de Registro Nacional de Veículos Automotores - RENAVAN IDETRAN. Observação: Os dados referentes aos anos de 2003, 2004, 2007, 2009 e 2010 referem-se ao mês de dezembro dos respectivos anos. Devido a indisponibilidade dos dados referentes a dezembro no sítio do DENATRAN, as informações associadas a 2006 e 2008 fazem alusão ao mês de novembro, e 2005 e 2011 são referidas a setembro.

Com a exceção de 2004 e 2008, o acréscimo anual de motocicletas em relação ao ano anterior sempre foi crescente e o incremento acompanhava a intensificação do processo migratório, principalmente para o trabalho nos canaviais do Estado de São Paulo. No período de dez anos, ocorreu um aumento de $1.121,1 \%$ na quantidade de motocicletas emplacadas em Timbiras, pois os registros do Sistema de Registro Nacional de Veículos Automotores - RENAVAN IDETRAN, apontou a existência de 95 motocicletas emplacadas no município maranhense em 2001, número que foi adicionado a 970 unidades até setembro de 2011.

As motocicletas, segundo Silva (2008, p. 173) é o objeto de consumo adquirido a duras penas a partir dos recursos poupados pelos trabalhadores migrantes, principalmente dos mais jovens e solteiros. Segundo a autora, a 
motocicleta é uma mercadoria incorporada, por meio do processo migratório, à paisagem dos municípios de moradia das famílias de trabalhadores maranhenses novos elementos, promovendo a redefinição da sociabilidade em várias esferas: "(...) Aos poucos, vai se constituindo uma cultura migratória que redefine as práticas sociais, os estilos de vida e as visões de mundo" (SILVA, 2008, p. 173) [grifos da autora ].

Durante a pesquisa de campo, pudemos observar em vários momentos a presença imponente das motocicletas em relação aos demais veículos utilizados no município de Timbiras, como o registrado na Figura 3 abaixo.

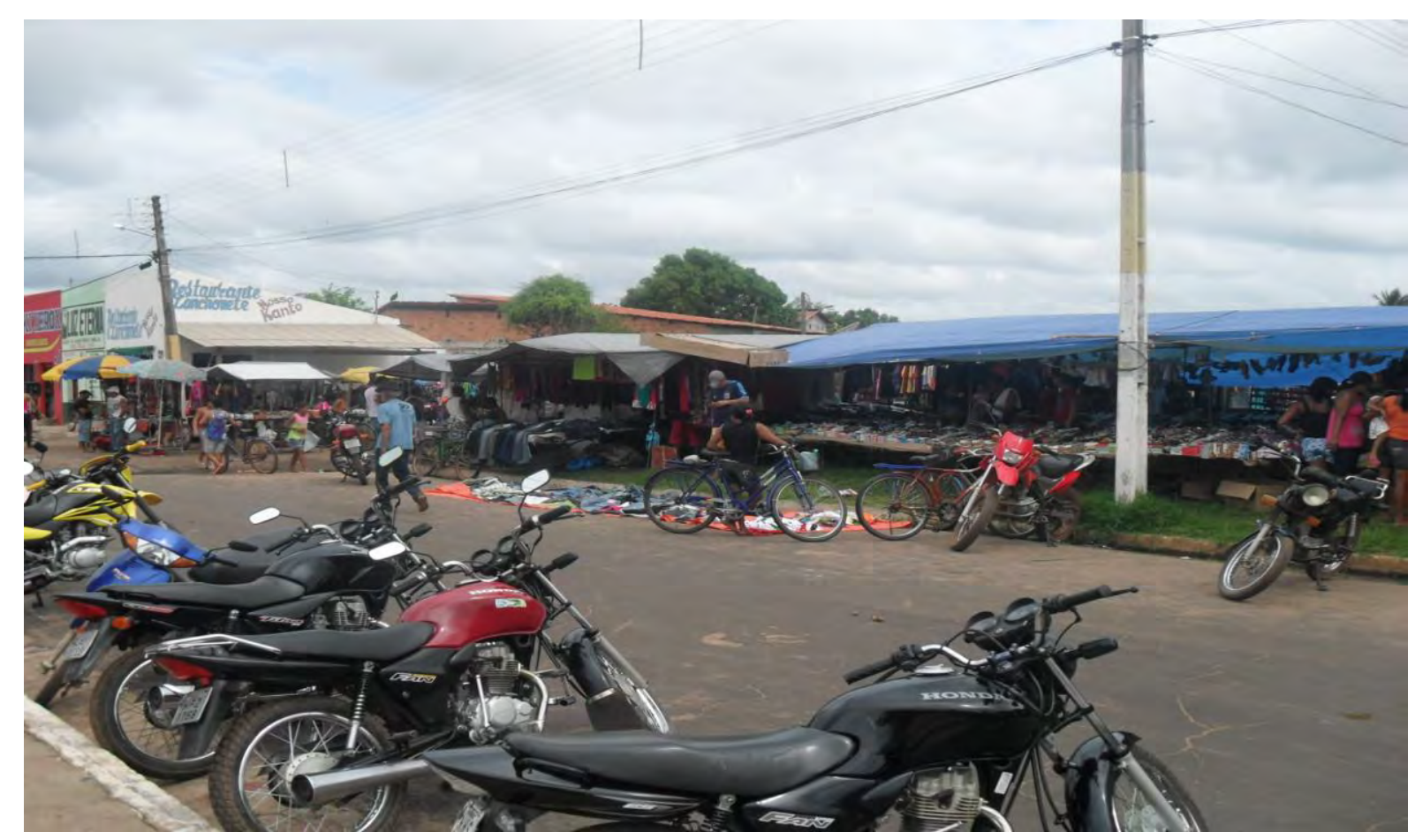

Figura 3 - Duas rodas. Motocicletas estacionadas próximas à feira semanal na cidade de Timbiras/MA.

Foto do autor, 18 de Janeiro de 2011.

O crescimento da quantidade de motocicletas circulando pela cidade de Timbiras ou pelos povoados do interior do município, também representou um aumento no número de acidentes de trânsito e até mesmo de mortes ${ }^{8}$. Contudo a aquisição da moto apresenta vários significados.

8 Os acidentes de trânsito envolvendo motocicletas também ocorrem em razão da reduzida fiscalização por parte das autoridades municipais, e também da não utilização, por parte dos condutores e passageiros de equipamentos indispensáveis à segurança pessoal como o capacete. 
Há também os serviços de moto-taxi, exercidos muitas vezes por homens que decidiram encerrar ou dar uma pausa, na circulação migratória, e ficar um tempo em Timbiras, assim como pessoas que trabalham diretamente com a atividade.

O serviço apresenta uma procura relativa, em razão da quantidade pequena de automóveis no município, da precariedade dos sistemas de transporte coletivo no município e da ausência de facilidades de acesso e disponibilidade de horários oferecidos por empresas de ônibus intermunicipais que passam pelo terminal rodoviário de Timbiras. Além disso, apesar do incremento considerável no número de motocicletas e motociclistas no município, o serviço de moto-taxi oferece uma possibilidade acessível de circulação no meio urbano, no interior da área municipal e também pelas cidades e povoados de municípios vizinhos, sobretudo para aqueles que não dispõem do veículo motorizado.

O objeto de consumo de muitos agentes sociais, sobretudo do sexo masculino, e solteiros, que migram para o labor nos canaviais do Centro-Sul do Brasil, possibilita muitas vezes a intensificação de redes territoriais estabelecidas entre os povoados e as roças, na área rural, com a cidade. A atividade de campo em alguns povoados da área municipal próximo ao núcleo urbano de Timbiras, só foi possível devido ao serviço de moto-taxi, principalmente em razão das fortes chuvas de janeiro. Povoados distantes do núcleo urbano exigem, mesmo com as facilidades na locomoção com devido a movimentação intensa de motocicletas pelas estradas no interior da área municipal, passou a vender gasolina. Observe a Figura 4: 


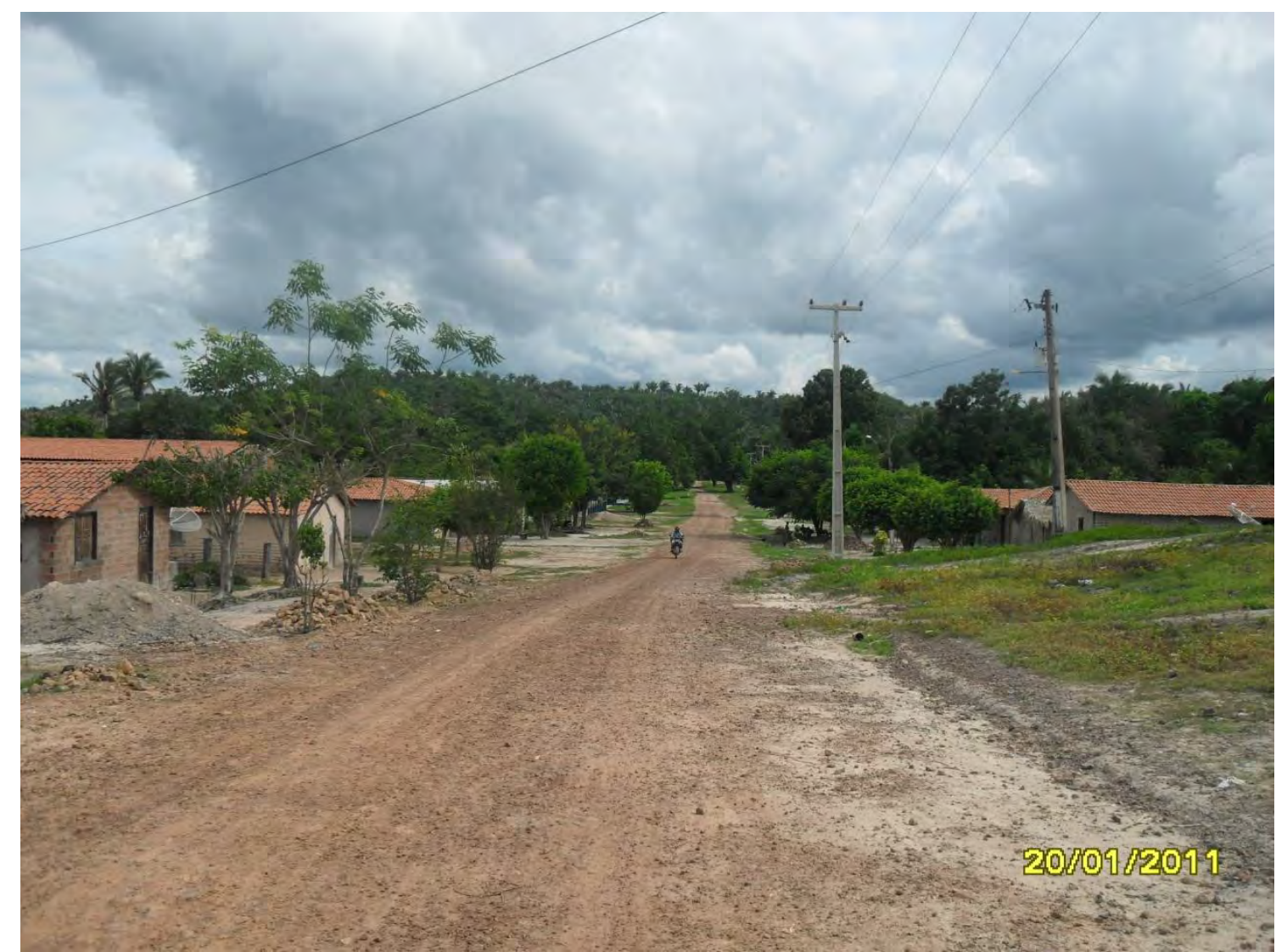

Figura 4 - Caminho pelo interior. Vista parcial da via de comunicação do povoado Flores, no município de Timbiras/MA. As motocicletas hoje realizam o importante papel de permitir o intercâmbio material e simbólico entre a cidade e os povoados e roças do interior do município de Timbiras.

Foto do autor, 20 de Janeiro de 2011.

Ainda com relação aos meios de transporte, notou-se também a existência de taxis que faziam rotineiramente o trajeto entre Timbiras e as cidades vizinhas durante várias vezes ao dia, muitas vezes embarcando uma quantidade não permitida de passageiros no automóvel, cobrando um preço bem menor ao praticado pelas empresas de ônibus que realizavam o itinerário entre os terminais rodoviários municipais. Esses taxis levavam as pessoas até o seu destino, ou próximo deles, executando várias paradas para o embarque e o desembarque de pessoas e para a arrumação de suas bagagens. Essa experiência se concretizou no decorrer da pesquisa de campo entre a cidade de Timbiras e Codó, e viceversa.

Podemos associar essas formas de transporte acima referidas a partir da precariedade do transporte público, no âmbito municipal e regional, para pensarmos o caso em tela, e dos descompromissos por parte das autoridades do 
poder público, em diferentes esferas administrativas, de refletir e pensar em estratégias e políticas públicas para reverter este quadro e garantir uma locomoção decente para a maioria da população, que diante do descaso do Estado, cria e recria mecanismos mínimos que permitem o seu transporte de um local a outro, porém em condições extremamente precárias, repleta de riscos, em razão da negação ou descaso do poder público em cumprir um direito social.

Diante do exposto, podemos relacionar tal situação às condições extremamente precárias de transporte interestadual, a partir dos ônibus clandestinos, e assim refletida por Vettorassi (2010, p. 190 ):

(...)Para a garantia de sobrevivência e melhores condições de vida, há uma necessidade muito maior de contar uns com os outros para suprir as carências de um Estado deslegitimado e impotente, que nem sequer pode contar com um comércio eficiente, como o que poderia ser feito pelas empresas de ônibus

Vettorassi (2010, p. 190) na citação acima registra que a construção de redes sociais e do espírito comunitário entre os migrantes permite o transporte de centenas de homens, mulheres, famílias, entre municípios do Piauí e o Estado de São Paulo, que em razão das condições de pobreza e de precariedade, para não dizer ausência, do poder público, minimamente organizaram estratégias para garantir o deslocamento entre uma região e outra. $O$ mesmo vale para as modalidades de transporte existentes no âmbito local em Timbiras, na qual o Estado legal não supre as necessidades de transporte digno para a maior parte da população. A importância dos ônibus clandestinos para esse deslocamento de longa distância será analisada no capítulo três.

O crescimento do número de motocicletas, dos serviços de moto-taxi e de taxi no âmbito intra e intermunicipal também pode ser relacionado com a elevação da taxa de urbanização verificada em Timbiras, que pode ser verificada por meio da Tabela 3. 
Tabela 3 - População Urbana e Rural do município de Timbiras e do Estado do Maranhão (1991, 2000 e 2010).

\begin{tabular}{|c|c|c|c|c|c|c|}
\hline Local & Censo & \multirow{2}{*}{$\begin{array}{c}\text { População Urbana } \\
\text { Demográfico }\end{array}$} & População & \multicolumn{2}{|c|}{ População Rural } \\
\cline { 3 - 7 } & Absoluta & Em \% & Absoluta & Em \% \\
\hline \multirow{3}{*}{ Timbiras } & 1991 & 22.960 & 7.815 & 34,04 & 15.145 & 65,96 \\
\cline { 2 - 7 } & 2000 & 26.401 & 13.954 & 52,85 & 12.447 & 47,15 \\
\cline { 2 - 7 } & 2010 & 28.007 & 17.471 & 62,38 & 10.536 & 37,62 \\
\hline \multirow{3}{*}{ Maranhão } & 1991 & 4.930 .253 & 1.972 .421 & 40,01 & 2.957 .832 & 59,99 \\
\cline { 2 - 7 } & 2000 & 5.651 .475 & 3.364 .070 & 59,52 & 2.287 .405 & 40,48 \\
\cline { 2 - 7 } & 2010 & 6.569 .683 & 4.143 .728 & 63,07 & 2.425 .955 & 36,93 \\
\hline
\end{tabular}

Fonte: IBGE. Censo Demográfico de 1991.

Censo Demográfico de 2000.

Censo Demográfico de 2010.

O município maranhense possuía uma expressiva população rural em 1991 $(65,96 \%)$ e em menos de uma década reverteu este quadro, apresentando $52,85 \%$ de seus habitantes residindo na cidade. Pela primeira vez em sua história, o Estado do Maranhão e o município de Timbiras exibiram, em um censo demográfico, exibiam uma taxa de população urbana superior à rural. No entanto, esses números eram inferiores a média nacional do período, que registrava uma taxa de urbanização de $75,6 \%$ no Censo de 1991 e $81 \%$ no seguinte. A partir desses números, também verificamos o acelerado crescimento da população urbana de Timbiras, entre os Censos Demográficos de 1991 e 2010, a partir da redução de $28,7 \%$ da participação da população rural, no conjunto da população total do município timbirense.

$\mathrm{Na}$ cidade também cresceu, a partir dos anos 1990, o número de habitantes, provenientes, sobretudo da área rural de Timbiras. Vivem, geralmente, em bairros da periferia urbana, que foram construídos ou expandidos neste mesmo período.

Há famílias que perderam a terra ou foram expulsas dela, mas guardam um vínculo precário com a mesma por meio da prática do arrendamento (rendeiros), e que experimentam um processo de intensificação da precarização das condições de reprodução social camponesa, uma vez que não possuem terra, trabalham em terra de dono, pagam renda, e porque também ocorreu uma separação espacial 
entre a casa de residência (a família vive na cidade) e a roça na área rural, que representa uma limitação para o trabalho da família na terra, sobretudo para aquelas nas quais os integrantes jovens da família migraram para as regiões canavieiras paulista, como podemos verificar na fala de um entrevistado:

(...) eu trabalho em terra arrendada, nós não temos terra lá não. Porque nós trabalha numa terra lá, nós não pagamos renda porque há quatro tipos de comunidade, não sabe? Lá tem um rapaz que tem uma terra, mas aí ele não tem as escrituras da terra, aí a gente trabalha na terra lá e não paga nada não. Agora, só que tem muitos que, eles passam cobrando a gente, tem muitos que pagam, mas tem outras pessoas que não pagam não, que a terra lá, eles não tem as escrituras da terra, a terra está voluntária, aí a gente está lá, não é?Aí lá no setor em que a gente trabalha, muita gente de lá, quase todo mundo já tem suas casinhas na rua, porque fazendo assim a sua segurança, porque de repente aparece uma firma e compra a terra, e aí nego fica no meio do quê, porque para lá, para nós, é o seguinte, quando aparece um fazendeiro que tem dinheiro, pode ter o tanto de morador que tem dentro daquela área, se eles entenderem, e desapropriarem, eles desapropriam rapidinho, porque aí eles fazem 0 seguinte, eles não correm com a gente, mas eles mandam roçar, fazer aquele roço, aí o cara tem que sair , porque quando põe fogo que tiver roça em redor, do barraco tudo e aí a gente tem que sair. Aí foi, como eu estou falando, o calculo que eu fiz de ter comprado essa casinha lá, na rua, já é minha segurança, por causa disso (...).

(Antônio Carlos, 44, casado. Testemunho oral colhido em 24/10/2010, na cidade de Guariba/SP. Caderno de entrevistas, p. 45)

A "casa na rua" é representada como a condição que a família expropriada tem de minimamente se reproduzir, diante da violência dos processos de expulsão e de grilagem de terras:

seja quando um rapaz que tem uma terra, mas aí ele não tem as escrituras da terra passam cobrando a gente ou quando aparece um fazendeiro que tem dinheiro, pode ter o tanto de morador que tem dentro daquela área, se eles entenderem, e desapropriarem, eles desapropriam rapidinho. 
A construção da casa na cidade é, portanto a possibilidade, que a família camponesa tem de se reproduzir socialmente, diante de um contexto marcado pela impossibilidade ou dificuldades de sua reprodução social na terra, que vêm ocorrendo no interior do município de Timbiras. Ela é também o objetivo de muitos trabalhadores migrantes, principalmente os que são casados, ou que pretendem se casar, diante do vínculo precário da família destes com a terra, ou às práticas limitantes do arrendamento, que comprometem a reprodução social camponesa, como pudemos perceber a partir do testemunho oral de Valdenir, cuja experiência migratória será contada no capítulo três.

A diferença nos estilos e visões de mundo entre a vida na cidade e nos povoados do interior municipal é assim descrito por meio do testemunho oral abaixo:

\footnotetext{
Pesquisador: $\mathrm{E}$ como que era morar num povoado e como que é morar aqui na cidade? A senhora nota alguma diferença?

Francisca: Sim. No interior é bom, por uns pontos, não é. Mas por outros, não é. Porque no interior, a gente vive de trabalhar assim de roça, a gente tem as coisas, não é, assim. Tudo fica mais melhor para a gente, não é? E na cidade, se torna mais ruim assim, porque que, por causa de que na cidade, se ficar parado, o negócio pega, não é? E aí a gente não tem emprego, não é, para trabalhar, não é, para levar a vida mais melhor. Aí, é que nem eu, por causa que está, a gente diz, não é, tem que separar mesmo não é, que é para poder, não é (...).

(Francisca, 42, casada. Testemunho oral colhido na cidade de Timbiras/MA, em 16/01/2011. Caderno de Entrevistas, p. 75).
}

A necessidade de dinheiro, a expulsão do campo, as dificuldades advindas da reprodução social na terra e a escassez de trabalho no núcleo urbano intensificam o processo de precarização das famílias que foram forçosamente obrigadas a se instalar nas cidades, nos bairros da periferia, nas chamadas" pontas de rua". A migração rural- urbana que se acirrou, desde o fim dos anos 1970, conformou o que denominamos de territorialidade de "ponta de rua".

Almeida (2005, p. 139) verifica processo semelhante nos municípios de Viana e Penalva, na Baixada Maranhense. Nas palavras do autor: 
A usurpação dos direitos não tem significado, entretanto, ausência de resistência. As precárias condições na cidade fazem com que mantenham fortes laços com as atividades agrícolas e extrativas. Elas ocorrem de diversas formas. Apesar de morarem na cidade, vivem como se estivessem no campo, trabalhando intensamente em áreas de cultivo que passam a ocupar. Mantém assim as chamadas "roças" e se dedicam às práticas extrativas.

Essa situação, portanto não elimina a origem e a condição camponesa da família, pois mesmo não possuindo terras, ou sendo pressionados a morar na cidade por motivos como saúde, estudo dos filhos e recebimento da aposentadoria, mantém mesmo que de forma cada vez mais precária a posse, propriedade ou por meio do arrendamento, parte significativa dos alimentos e do sustento da família a partir dos cultivos na roça, situadas no interior do município timbirense.

O mesmo adjetivo envolve também o trabalho da mulher e dos filhos, quando são jovens, nas lides cotidianas do trabalho na roça, e o descaso, histórico por parte do poder público, nas esferas municipal, estadual e nacional, em oferecer condições mínimas para garantir a agricultura camponesa no local, como assistência técnica, habitação e educação de qualidade, escoamento e comercialização de parcela dos cultivos alimentares da agricultura camponesa.

Apesar de impingido por sucessivos processos de precarização de sua condição camponesa, e inclusive por residir na cidade, não podemos pensar esses agentes sociais, homens, mulheres, famílias inteiras desligados de um modo de vida camponês. Neste sentido, aproximamos da posição de Silva (2009, p.30), historiador maranhense que se debruçou sobre a memória e identidade de trabalhadores rurais na região dos Cocais entre 1990 e 2008. Conforme o autor:

O camponês com $O$ qual estou lidando guarda especificidades e peculiaridades do Estado do Maranhão. É um trabalhador que mantém sua roça na zona rural, mas já reside temporária ou definitivamente na periferia das cidades de Presidente Dutra ou Dom Pedro. Interpreto-o como camponês porque ainda mantém vínculo, mesmo não estável com a terra, pois não possui um pedaço de chão para plantar e depende do proprietário de quem a arrenda para a roça. (...) Notadamente, trata-se de camponeses 
semi-urbanos, pois alguns tem "a casa da cidade" (MORAES, 2000), "situada quase sempre na periferia dos centros urbanos (SILVA, 2004) e a casa da roça, onde passam a maior parte dos dias.

O que vale destacar, por ora, foi o acirramento da precarização das condições de reprodução social do campesinato, que produziu uma intensa migração rural-urbana em Timbiras, que, contudo não representou um distanciamento do trabalho agrícola daqueles que instalaram a sua residência na cidade.

Muitas famílias de origem camponesa, expulsas dos latifúndios, converteram-se em rendeiros, pagando uma renda em produto anual, assentada em linhas de arroz, para o proprietário da terra, deslocando-se de suas casas na cidade até os roçados distantes no interior do município maranhense. Há também situações em que o rendeiro, ou pequeno proprietário de terras, possui uma casa de residência, na qual a família se aloja, e uma casa de morada, no arrendamento, e usada pelos integrantes da família em idade produtiva ou por toda ela nos períodos que demandam mais trabalho nas lides da roça, conforme pudemos constatar na pesquisa empírica, e por meio dos apontamentos de Silva (2009, p. 94) e Carneiro et al. (2007; p. 2).

A casa na cidade, na "ponta de rua", também é almejada por famílias que incentivam a educação dos filhos, em razão da proximidade com a escola, das condições de saúde, sobretudo dos mais idosos, ou do acesso a benefícios sociais como escolas e hospitais públicos além do recebimento da aposentadoria, como pudemos verificar por meio do testemunho oral abaixo:

Pesquisador: E o que fez a senhora sair do interior e vir para cá?

Raimunda: É porque minha sogra era doentinha, minha sogra era doentinha, tinha uma perna quebrada e aí meu velho não podia andar com eles para tirar o dinheiro. Era um sufoco, não é. Aí nos viemos para cá, para ficar mais fácil. Mas foi o tempo que ela morreu, e nós fiquemos mesmo aqui. Foi só por causa disso. E botar os menino para estudar, nós temos um rapaizinho, uma menina e viemos para botar eles para estudar. (Raimunda, casada. Testemunho oral colhido em 19/01/2011 na cidade de Timbiras/MA. Caderno de Entrevistas, p. 146) 
Em outras situações, a casa de morada não existe mais, e foi substituída pela casa de residência na cidade. Outrossim, existem famílias, que não encontrando condições de reprodução social na unidade camponesa foram com a família para a sede do município, na qual construíram uma casa a residência familiar, em geral, construída com paredes de adobe), mas mantém a morada em sua pequena propriedade ou posse, apesar de deslocar-se diariamente, ou até mesmo ficar um tempo distante da família no período de trabalho mais pesado no campo. Estas famílias camponesas também sofrem um processo de intensificação da precarização das condições de reprodução social camponesa, de diferente proporção, como no caso anteriormente mencionado, processo este que se avoluma com a migração de integrantes da família para o labor, sobretudo, nos canaviais paulistas.

Desse modo, a pesquisa empírica permitiu, a partir da coleta de testemunhos orais, identificar uma série de situações contraditórias entre a cidade e o campo, de famílias de trabalhadores migrantes que recriaram uma territorialidade camponesa de "ponta de rua" na periferia do núcleo urbano de Timbiras e que experimentam a construção de diferentes territórios de migração perpassados por sua resistência mediante a um processo de intensa precarização das condições de reprodução social do campesinato regional. É nesse sentido que atentamos aqui para a conformação de uma territorialidade de "ponta de rua" na sede do município de Timbiras. Ponta de rua é denominação regional que se empresta a residência familiar na cidade, longe da morada e da roça, situada no interior da área municipal.

Carneiro et al. (2008, p. 18) indica que a maior parte dos camponeses que viviam de forma subordinada no interior de latifúndios até os anos 1970 foram ou estão sendo expulsos para os bairros de Timbiras, para as "pontas de rua". Bairros que foram recém-construídos ou ressignificados nos últimos anos para abrigar famílias de origem camponesa que foram expulsas ou forçados por limitações estruturais de permanecer com a família no trabalho na terra seja ela uma posse ou uma pequena propriedade fundiária.

A intensificação de uma territorialidade de "ponta de rua" na cidade está associada aos processos de expropriação e expulsão verificados ao longo das 
quatro últimas décadas, e, sobretudo nos anos 1990 e 2000, fruto da concentração fundiária no âmbito local, que acelerou o crescimento demográfico urbano.

Por sua vez, a falta de oportunidades de emprego na sede do município, nutriram redes multifacetadas de migração que configuraram e deram significado para a construção de territorialidades migratórias em diferentes, novas e mais distantes regiões do Brasil.

A territorialidade de ponta de rua configurou e deu novo significado a bairros como Forquilha, Anjo da Guarda, Horta, São Sebastião, que concentram uma grande quantidade de agentes sociais que experimentaram a migração para o trabalho degradante em outras regiões do país, ou mesmo, aqueles que até então "viviam de roça" e apresentaram o primeiro integrante da família a se enveredar neste processo social.

No entanto, a migração dos integrantes jovens da família sobrecarrega os familiares de idade avançada, que apresentam restrições físicas as lides rotineiras da agricultura camponesa ou às mulheres que permaneceram e que que se desdobram ainda mais entre as atividades domésticas na casa da cidade, o cuidado com os filhos, e também para muitas, o trabalho na roça. A soma das tarefas que já realizava, com as funções executadas principalmente pelo marido ou filhos mais jovens, ausentes, é assim explicitada por Francisca:

Pesquisador: Quando ele está lá, a senhora e os filhos da senhora que estão aqui cuidam da roça?

Dona Francisca: Cuida. Na primeira vez que ele foi, ele deixou a roça e eles cuidaram, não é da roça. Panharam o arroz, botaram para a casa, bateram, ajeitaram ,não é? E agora ele foi mais esse meu menino, meu menino voltou, não é? Aí veio para trabalhar na roça, não é? Quando ele chegou, estava só no ponto para a plantar, não é? Ele brocou a roça todinha, e ajeitou, e esperou só ele chegar para plantar. (Francisca, 42, casada. Testemunho oral colhido na cidade de Timbiras/MA, em 16/01/2011. Caderno de Entrevistas, p. 79)

O excerto acima mostra a estratégia e a preocupação da família de pequenos proprietários rurais de Timbiras, com a organização do trabalho na roça e o sustento na ausência do chefe de família, que é compensada pelo esforço 
laboral dos filhos mais jovens, em idade produtiva nos termos indicados por Shanin (1976). O início do plantio na roça, com a vinda das primeiras chuvas concentradas no verão, coincide com o regresso dos trabalhadores migrantes para o Maranhão, após o término da safra canavieira no Centro-Sul, como foi exposto na fala da entrevistada: "Quando ele chegou, estava só no ponto para a plantar". A colheita do arroz, realizada entre os meses de maio e junho ocorre simultaneamente ao trabalho na safra da gramínea, sendo necessário delegar aos que familiares que ficaram a colheita dos cultivos da roça. No entanto, quando não há mais integrantes da família, porque todos os filhos casaram, ou porque migraram, a saúde debilitada dos membros da família em idade avançada limitam a produção da unidade camponesa. Pudemos compreender o significado desta situação por meio dos registro orais abaixo:

Eu planto maniva, eu planto arroz, planto milho, planto feijão. Agora mesmo eu tenho um filho roçando porque meu menino pediu muito para eu não fazer roça que eu já estou velho, doente, aí eu só fiz uma linha. Nessa mesma eu já enchi de manaúba e feijão, está tudo cheio dele. Manauvinha, já está grande.

(Diocleciano,70, casado. Testemunho oral colhido em Timbiras, em 19/ 01/2011. Caderno de Entrevistas, p. 234).

(...) Eu mesmo chamo ele, meu filho, eu não aguento mais trabalhar, vocês tomam de conta de vocês da roça. Eu só é pra estar administrando, por que, serviço, eu não agüento mais. Esse daqui é casado, tem a família dele. Esse também é, mas sempre vem. Alias tem dois, tem um numa loja também, empregado. Ele também está no serviço hoje. Esses que estão lá vem preparar a roça que é pro consumo de todo o mundo. (...) Agora eu recibo auxílio de doença, porque eu sou doente, eu não posso mais trabalhar. Problema de coluna, acabou. Aí, pro segundo peguei esse negócio de, problema de alérgico, eu não posso trabalhar mais não. Ainda ontem eu mexi no Codó fui regularizar o laudo pra ir pro médico. Fui na Perícia para fazer perícia para receber o benefício

(Raimundo, 56, casado. Testemunho oral colhido no povoado Pedra Preta, Timbiras/MA, em 20/01/2011. Caderno de Entrevistas, p. 198, 203). 
Tira. Tira sim. Tira mandioca, é milho, melancia, é macaxeira. Macaxeira [barulho forte da chuva] é a mandioca, que a gente come ela cozida, não é? Aí vocês conhecem, não é? $\mathrm{E}$ aí depois faz a farinha, arroz, tudo dá! Fava, feijão, tudo dá! O que você planta dá! Graças a Deus, é pouco, mas dá! Não é muitão, porque mesmo o meu velho já é velho mesmo, coitado, a força é pouca, bota uma linha, duas linha, agora, mas, de primeiro era, se botar era doze linha, era assim. Agora não, três tá bom. Já tá cansadinho o velho mesmo. É assim. Nós vive assim, meu filho. E Deus abençoa tudo o que a gente vai passando. Somos pobre sim, mas vai passando, não é? Pois é.

(Raimunda. Testemunho oral colhido na cidade de Timbiras, em 19/01/2011. Caderno de Entrevistas, p. 158)

Os entrevistados revelaram as limitações para o trabalho rotineiro nas lides da agricultura por parte de dois chefes de família. As restrições impostas pela saúde fragilizada dos testemunhos é compensada pelo trabalho dos filhos alocados no município, garantindo maiores possibilidades de rendimento dos produtos do roçado familiar, sobretudo para os camponeses sem-terra, dependentes do sistema de arrendamento. Esta prática se realiza a partir do pagamento anual em espécie, principalmente de arroz, ao proprietário da terra, comprometendo os produtos do roçado, sobretudo os obtidos a partir do labor de integrantes da família que apresentam a limitações físicas para a consecução de atividades no roçado familiar, como pudemos comprovar a partir dos excertos apresentados anteriormente.

O acirramento da precarização é percebido no sentido de que as condições de reprodução social do campesinato no município eram marcadas, pelo mandonismo dos latifundiários sobre os moradores das grandes propriedades, os posseiros e estabelecendo restrições ao arrendamento. De acordo com Carneiro et al. (2008, p. 21), as privações dos rendeiros ocorrem em decorrência da cobrança anual da renda em produto (geralmente em linhas) por parte do proprietário da terra - e que muitas vezes não condiz com o aproveitamento da mesma, seja em função da fertilidade da terra, seja em relação a diminuição do ritmo de trabalho da função na mesma, comprometido pela migração dos mais jovens e pela idade dos integrantes de idade avançada do núcleo familiar. A exploração do arrendamento é assim percebida pelos entrevistados: 
Aqui é terra de donos, quando a gente começava a produzir eles tiram a gente da terra e tive que vir para cidade. (...) Meus irmãos é que ficaram no interior, estão em propriedade alheia. Pagam em produto e quando não dá tem que pagar assim mesmo.

(Maria Cleonice, 48, casada. Testemunho oral colhido em 11/01/2010, na cidade de Timbiras/MA. Caderno de Entrevistas, p. 10).

Pesquisador: $O$ senhor tinha roça aqui perto, seu Sebastião?

Sebastião: Era pro um espaço de légua e meia.

Raimundo: Cinco quilômetros ou mais.

Pesquisador: Tá certo! E na roça que o senhor tinha, é, o senhor estava em terra de dono ou era terra própria?

Sebastião: Era terra de dono.

Pesquisador: O senhor pagava renda?

Sebastião: Pagava renda. Era uma terra fraca. Se dava um pouquinho, não era coisa de vantagem.Trabalhava muito e a produção pouca.

Pesquisador: $\mathrm{E}$ o senhor pagava mais em arroz ou outros produtos também?

Maria Cleonice: Pagava em arroz.

Sebastião: Pagava em arroz. Fui pagar em milho, uma vez, eles não aceitaram, o pouquinho de arroz que dava, que dava pra gente, precisava ir pra casa. (Sebastião, casado; Maria Cleonice, 49, casada. Testemunho oral colhido em 21/01/2011 na cidade de Timbiras/MA. Caderno de Entrevistas, p. 9)

A roça é fraca... Dá só para comer e as vezes nem dá para comer... A terra é fraca, não dá nada... A gente trabalha na roça porque é pobre mesmo, porque não dá nada... Serviço para trabalhar é difícil.

(Domingos, 59, casado. Testemunho oral colhido em Timbiras, em 11/01/2010. Caderno de Entrevistas, p. 7).

As limitações da produção do roçado não são levadas em conta pelos grandes proprietários de terra, dispostos a cobrar a renda anual em linhas de arroz, mesmo o rendimento do cultivo sendo insuficiente até mesmo para suprir as necessidades da família. Sebastião revela em seu testemunho, a incompatibilidade de compensar o pagamento da renda em arroz, por milho, 
sujeitado ainda mais o camponês sem terra, empobrecido, onde o pouquinho de arroz que dava, que dava pra gente, precisava ir pra casa. A fala de Domingos reforça os argumentos de Sebastião, ao apontar as privações da agricultura camponesa, de uma roça fraca, insuficiente para manter o provimento alimentar da família.

A intensificação da precarização camponesa, também, foi impingida por meio da violência, praticada tanto por latifundiários que expulsaram camponeses, conferindo a propriedade da terra um sentido especulativo, como atesta Carneiro (2007, p. 224). Do mesmo modo, grandes grupos econômicos extra-regionais, obrigaram os camponeses a deixar suas terras, impondo-se, por meio de ameaças pessoais ou por meio de formas de violência simbólica ou material, como a queima da morada e destruição de roças camponesas no povoado de Campestre, no município de Timbiras, em 2004, conforme aponta Silva (2008, p. 169).

No entanto, a violência material e simbólica, registrada nessa e em outras ocasiões, não é simplesmente aceita por parte daqueles que foram expulsos de suas roças, sua casa de morada, de seu modo de vida camponês no interior da área municipal de Timbiras. Há experiências de resistências, nutridas tanto do ponto de vista pessoal, materializadas por processos judiciais movidos por camponeses, como o ocorrido na fazenda Campestre (SILVA, 2010, p. 16) e também a partir de organizações camponesas de luta pela terra, que se materializaram no Projeto de Assentamento CIT/Novo Horizonte, situado entre os municípios de Timbiras e Codó, que discutiremos mais adiante.

A migração, processo social que acompanha a vida de muitos trabalhadores maranhenses também foi experimentado por outros integrantes de suas famílias de outras gerações. É importante destacar que parte dos habitantes do município de Timbiras possui ascendentes familiares originários de outras regiões do Maranhão e até mesmo de outros Estados, como Piauí e Ceará.

Ferreira (2010) propõe uma discussão sobre as linhas interpretativas acerca das migrações processadas a partir da segunda metade do século XIX de regiões que constituem atualmente a macrorregião Nordeste para a economia extrativa da Amazônia e terras devolutas do "Maranhão". A autora analisa a "invenção de tais recomeços deixando em suspenso ao longo da pesquisa a 
naturalizada e inextrincável relação da migração dos nordestinos com a seca e com a "incorporação acrítica das fronteiras oficialmente legitimadas para pensar os referentes "Maranhão", "Piauí", “Ceará”, "Paraíba”, "Rio Grande do Norte”, etc.".

Desse modo, para a autora, a partir da discussão feita em Bourdieu (2003):

faz-se necessário imputar a tais categorias a artificialidade e arbitrariedade inerentes à sua invenção, atentando para a possibilidade de pensar a partir de outras fronteiras instituídas cotidianamente nas práticas culturais de migrantes, que violam-nas, subvertem-nas, suprimem-nas e reinventam-nas. Nas artes de fazer de novos/velhos espaços, mapas abstratos e absurdos diluem-se e fundemse performando fronteiras movediças que desafiam a fala autorizada do Estado e dos saberes legítimos.

O trabalho de Ferreira (2010) é importante por considerar outras dimensões da migração experimentada no passado desses agentes sociais, tirando o peso macroestrutural da interpretação, que predominou em boa parte dos estudos sobre esta temática, além de refutar uma leitura enraizante da identidade social destes homens e mulheres ancorada em territórios políticoadministrados erigidos por forças políticas do Estado. Evita ficarmos reféns de interpretações estruturantes, apoiadas na seca e congeladas a partir de uma identidade territorial e social assenhorada pelo Estado, assim como na recriação de territórios e uma sociabilidade baseada em um regionalismo nordestino, pensado e imposto pelas elites.

Assim não percebemos uma configuração histórica de uma territorialidade cearense ou piauiense em Timbiras, na sede do município ou nos povoados do interior durante a pesquisa de campo, ou uma identidade social e territorial construída a partir de retirantes de suas ditas áreas de origem. Nas palavras de um entrevistado:

No Piauí era sempre era falado que era meio ruim , e aí eu me convenci com um irmão da minha mãe, que puxou ela aqui para o Maranhão, caçando acho que melhora, não sabe? (Raimundo, 56, casado. Testemunho oral colhido no povoado Pedra Preta morador do povoado Pedra Preta, no município de Timbiras/MA, em 20/01/2011. Caderno de Entrevistas, p. 268) 
Pensamos que esta migração, entendida como processo social está relacionada à precarização das condições de reprodução social de um campesinato, que se desloca durante parte significativa de suas vidas, "caçando melhora", de acordo com Raimundo. Nesse sentido, ressaltamos os trabalhos de vários estudiosos (GARCIA JR, 1983, 1990; HEREDIA, 1979; MENEZES, 1985, SUAREZ, 1977) que se debruçaram sobre o significado da migração como estratégia de reprodução social do campesinato, e manutenção do trabalho da família na terra.

E retomando Ferreira (2010):

Em relações de conflitos, tensões e/ou interações e imbricamentos com homens e mulheres nascidos em terras do Maranhão ou oriundos de levas anteriores de outros Estados do Nordeste, tais atores foram enredados em teias sociais pré-existentes, submetidos às regras de comportamento e representações sociais desses lugares, ao mesmo tempo em que resignificavam cotidianamente identidades e práticas culturais locais nas suas apropriações e reapropriações.

A pesquisa de Ferreira (2010) circunscrita a diversos municípios do médio Mearim e faz alusão a um período em que o Maranhão foi designado por muitos autores como a válvula de escape para os conflitos agrários que se intensificaram, sobretudo em regiões do Sertão dos Estados do Ceará e Piauí.

As migrações, portanto, não são um acontecimento recente, para parte significativa das famílias estabelecidas no município de Timbiras, em particular daqueles que se movimentam sazonalmente para as plantações de cana de açúcar no Estado de São Paulo. Parte importante da população de origem camponesa dos vales úmidos do Maranhão (Itapecuru, Mearim, Pindaré e Grajaú) e de regiões da Pré-Amazônia maranhense resultaram de fortes movimentos vindos do Ceará e do Piauí, motivadas por episódios de seca que atingiram duramente seus roçados, em seus Estados de origem e da pressão do latifúndio pecuarista sobre suas terras (Andrade, 2005, p. 60, 233). Esse processo intensificou-se no final da década de 1950, aumentando consideravelmente a 
população rural da zona do babaçu desde a calamitosa seca de 1957, ocupando os vales fluviais do centro e do oeste do Maranhão na fronteira amazônica, que na época eram esparsamente povoados (MAY, 1990, p. 62).

Igualmente, a historiografia maranhense registrou ocorrências de movimentos de migrantes de províncias, hoje localizadas na região Nordeste para o Maranhão desde a década de 1870(FERREIRA, 2010). A migração, portanto, é um componente importante no processo de reprodução do trabalho camponês na terra, mesmo em direção a regiões distantes das ocupações da família.

No entanto, Almeida (1981, p. 21) aponta um quadro de reversão do saldo migratório do Estado do Maranhão, entre 1970 e 1980. Baseado nos dados do Censo Demográfico de 1980 constata que o Estado maranhense apresentou pela primeira vez em sua história recente, uma migração líquida negativa. May (1990, p. 63), ancorado nesses dados, aponta que mais de meio milhão de pessoas migraram para outros Estados do Brasil, na década de 1970. Almeida (1981, p. 21) indica também a emigração de maranhenses para países latino americanos, de acordo com notícias jornalísticas que relatavam a expulsão de maranhenses, dos garimpos de ouro da bacia do rio Orenoco, na Venezuela, no final dos anos $1970^{9}$.

Em outras palavras, o Maranhão, um Estado que recebeu levas de famílias camponesas, expulsas pelos conflitos fundiários, e pelo processo de modernização da agricultura, nas regiões de ocupação mais antiga do do Sertão nordestino, convertia-se nos idos da década de 1970, em um grande exportador de mão-de-obra, notadamente para os grandes projetos agropecuários (sobretudo nas atividades de retirada da cobertura vegetal e formação de pastagens para o gado bovino) e de exploração mineral (com destaque, para as atividades de garimpo de ouro) na Amazônia Legal.

É também a origem de muitos trabalhadores que foram encontrados em condições análogas à de escravo ${ }^{10}$ nas áreas de expansão da fronteira agrícola

\footnotetext{
${ }^{9}$ Conforme indicado em Almeida (1981, p. 21 - 22): Os próprios pequenos produtores agrícolas maranhenses têm procurado o sul de Roraima e a região de Ciudad Bolivar na Venezuela, onde segundo estimativas oficiais há cerca de 10.000 garimpeiros em sua maioria maranhenses. Estes, periodicamente, são expulsos do território venezuelano e recambiados para o Território e Roraima. Fica, portanto, a pergunta: embarcar para onde?

${ }_{10}$ Condições análogas a de escravo, termo jurídico adotado pelos órgãos oficiais, como o Ministério do Trabalho e Emprego, Delegacias Regionais do Trabalho e Ministério Público do
} 
no Norte e Centro Oeste do país, e em condições de trabalho degradante nas terras do império do agronegócio no Centro-Sul canavieiro, para ficar nos casos mais expressivos. (MOURA, 2009, p.52).

A estrutura fundiária concentrada em nível municipal, que culminou com a intensificação dos processos de expropriação e expulsão de camponeses desde a década de 1970, no município de Timbiras é, segundo Carneiro et al. (2007, p.224) um dos determinantes estruturais da migração. O autor supracitado argumenta que:

Com o declínio do aproveitamento industrial do babaçu, a propriedade da terra passou a ser orientada para a atividade pecuária ou mantida como reserva de valor, visando à obtenção de alguma vantagem de crédito - caso dos incentivos fiscais (FINOR, FINAM e FISET) - ou sua venda em um momento de aquecimento do mercado de terras. (CARNEIRO et al., 2007, p. 224)

José de Souza Martins (1999, p. 79-80), ao discutir a política de concessão de incentivos fiscais na Amazônia brasileira durante o regime militar, afirma:

Ao contrário do que ocorria com o modelo clássico da relação entre terra e capital, em que a terra (a renda territorial, isto é, o preço da terra) é reconhecida como entrave à circulação e reprodução do capital, no modelo brasileiro o empecilho à reprodução capitalista do capital na agricultura não foi removido por uma reforma agrária, mas pelos incentivos fiscais.

As considerações de Martins (1999) apontadas acima são importantes para entender a face especulativa e rentista de muitos latifúndios situados no município de Timbiras, apoiados em uma rede de políticas de incentivos creditícios e fiscais fornecidos por instituições, promotoras da "modernização FINOR (Fundo de Investimento do Nordeste), FINAM (Fundo de Investimento da Amazônia) e FISET (Fundo de Investimentos Setoriais) como fora mencionado por Carneiro et al

Trabalho, entre outros, e está presente no artigo 149, do Código Penal Brasileiro. (MOURA, 2009, p. $27,42-43)$ 
(2007, p. 224) contribuíram para o processo de aquecimento do mercado de terras, ao permitir que os grandes proprietários fundiários apoderassem dos recursos públicos para a compra de terras, e promovendo a expulsão de camponeses do interior da grande propriedade, e de famílias de posseiros que trabalhavam na terra ocupada há gerações.

Como pudemos verificar, não houve uma diminuição da concentração fundiária em Timbiras, pelo contrário, ocorreu uma intensificação deste processo, legitimada pelo Estado ditatorial, a partir de políticas públicas que deu novas roupagens, e uma face "moderna" para o capitalismo rentista.

Nas palavras de Martins (1999, p. 40)

O modelo brasileiro inverteu o modelo clássico. Nesse sentido, reforçou politicamente a irracionalidade da propriedade fundiária no desenvolvimento capitalista, reforçando, consequentemente, o sistema oligárquico nela apoiado.

Os incentivos creditícios fomentaram diversas experiências de modernização da economia apoiada no extrativismo do coco babaçu, como a da Companhia Industrial Técnica (CIT) no município de Timbiras. De acordo com May (1990, p. 255):

Os administradores da Companhia Industrial Técnica (CIT) e da Empresa Industrial de Bacabal (EIB), que adotam ambos a técnica $P S Q$ e incluem a produção de carvão e quebra de amêndoas, investiram no raleamento das palmeiras e no estabelecimento de pastos nas suas propriedades nos municípios de Timbiras e Bacabal, respectivamente. De acordo com um informante, a produção dos 13 mil hectares da fazenda da CIT em Timbiras era, inicialmente de 1,5 toneladas por hectare. Após o raleamento e 0 estabelecimento do pasto, a produção aumentou para 2,5 toneladas.

A iniciativa da CIT, em Timbiras está associada a adoção de novos referenciais técnicos que permitiram um aproveitamento racional e intensivo dos subprodutos do fruto do babaçu. De acordo com May (1990, p. 45): 
A tecnologia PSQ [pelagem, separação e quebra] consiste no processo de descartar o fruto, separando o mesocarpo do epicarpo e quebrando o endocarpo para extrair as amêndoas foi adotado, com graus variados de sucesso, em diversos empreendimentos voltados para a industrialização do fruto na década de 1970

As iniciativas pautadas nas experiências de aproveitamento integral do fruto e de incremento na produtividade do babaçu, a partir da tecnologia PSQ, apoiavam-se na aquisição de terras com uma grande densidade de babaçuais, e constituíam empreendimentos agroindustriais, muito distintas, da maior parte das indústrias de beneficiamento do óleo de babaçu, assentadas no fornecimento das amêndoas da palmácea, por meio de comerciantes e outros intermediários (MAY, 1990, p. 254).

A experiência da CIT em Timbiras promovia a conversão das famílias quebradeiras de coco em assalariados, em um ritmo industrial e de intensa produtividade dos produtos comercializáveis da palmácea. Por mais que fosse uma experiência embrionária no universo da industrialização do óleo, no período representou a tentativa de imprimir um ritmo agroindustrial ao setor, em consonância com as políticas e o processo de modernização no campo empreendida a nível nacional e estadual, separando a economia extrativa do babaçu da importância complementar que tinha para a economia camponesa.

A experiência da CIT, para alguns camponeses representou:

Ah, como é que se diz aí que essa terra aqui foi arrendada para a CIT, aí depois disso, ela foi a falência, que ela comprava o coco, com casca mesmo e quebrava aqui em Timbiras. Fazia, como é que se diz o benefício dele, beneficiava o coco lá com eles mesmo lá. Não queria que a gente beneficiasse ele aqui, 0 coco, de qualquer maneira, de jeito nenhum.

(Antônio, 47, casado. Testemunho oral colhido no povoado Melancia, em Timbiras/MA, em 20/01/2011. Caderno de Entrevistas, p. 236).

O desinteresse econômico e social da CIT pela quebra manual do coco babaçu e a aposta na industrialização do coco integral para suprir a indústria de 
óleo, significavam a proibição por parte dos proprietários da CIT da quebra manual do coco da palmácea, já que o camponês só podia coletar o coco, oferecendo-o integralmente para ser quebrado mecanicamente na indústria, reduzindo os parcos recursos financeiros que complementavam a renda da família camponesa.

A industrialização integral do coco era apontada no discurso dos industriais de óleos vegetais como a "solução" para a crescente escassez do babaçu no período da entressafra, que tornavam as indústrias ociosas pela falta de matériaprima, oferecida pela quebra manual (INSTITUTO DE PESQUISAS ECONÔMICAS E SOCIAIS, 1981, p. 13). De acordo com Antônio Francisco da Silva, representante da CIT em fala proferida na mesa redonda intitulada "O Babaçu e suas Perspectivas", organizada pelo IPES, na capital maranhense, em 1981:

(...) não há dúvida nenhuma de que a riqueza do babaçu do Maranhão, se continuar tradicional, não chegará a canto nenhum, principalmente porque há um desinteresse manifesto cada vez maior pela quebra, quer de ordem social, quer de ordem econômica. (...) Não temos qualquer dificuldade na aquisição do coco, o adquirimos de terceiros e a oferta é maior do que a nossa procura. Temos o coco que queremos dentro da fábrica e com uma remuneração compensadora ao coletador, concorrendo com todos. Com isso queremos mostrar, não que nossa empresa está bem, queremos mostrar que o aproveitamento integral do babaçu pode remunerar bem, quer ao coletador, quer ao proprietário, e nos parece que é a única alternativa válida para manter os babaçuais e essa riqueza que é muito grande.(...) Somos da opinião de que não devemos aumentar os quebradores do Maranhão, a industrialização do coco integralmente deve suprir a indústria existente. (IPES, 1981, p. 18 - 19).

Percebe-se, por meio da fala registrada pelo representante da CIT, a desconsideração pela importância da quebra do coco babaçu na complementação dos rendimentos da família camponesa nas regiões de ocorrência da palmácea no Estado, atividade que supre as limitações da unidade doméstica, historicamente subordinada a um processo intenso de empobrecimento. 
A negação da importância destes agentes sociais na quebra do coco babaçu, sobretudo das mulheres é também uma negligência cometida contra o processo histórico de constituição do campesinato maranhense na região dos Cocais. É reduzir as quebradeiras de coco, à coletadoras ${ }^{11}$, ignorando a fonte de ganho obtida nos meses de redução da atividade do trabalho nos roçados por meio da venda das amêndoas, do azeite ou do aproveitamento do mesocarpo, para a produção de farinha, usada no consumo doméstico, entre outros.

Transpõe-se para a realidade agrária dos Cocais um modelo industrial, que impõe à família camponesa a condição exclusiva do assalariamento, da competição por ganhos, elementos que não estão imbuídos em suas relações sociais e morais com o mundo.

A racionalização da produção industrial, apoiada no histórico discurso da escassez ou da baixa qualidade da amêndoa adquirida das quebradeiras de coco, traz um arranjo orquestrado por representantes do capital industrial, de políticos que atuam na esfera local, regional e estadual, além de um corpo técnico que despreza o significado das múltiplas relações que a família camponesa sustenta por meio da coleta e quebra do coco, preservando os babaçuais e as práticas cotidianas de uso comum da terra e dos recursos naturais. O discurso modernizante da extrato-indústria do coco babaçu, traz consigo a intensificação do processo de concentração fundiária e da apropriação da renda da terra, a partir do controle, cercamento e grilagem das terras, expropriando camponeses, acirrando a migração para as cidades e acelerando o processo de reprodução do capitalismo predatório e rentista, a única alternativa válida para os representantes do capital.

Não tardou para a experiência de a CIT malograr em Timbiras, e com ela também as inovações técnicas para inserir a economia industrial do babaçu ao processo de modernização conservadora no campo maranhense. Tentativas

\footnotetext{
${ }^{11}$ Almeida (2005, p. 24 - 25) descreve as condições de trabalho exercidas pelos catadores de coco, na região tocantina maranhense e no extremo norte de Tocantins: Consistem em trabalhadores aliciados por interesses das carvoarias e indústrias guseiras e de óleos vegetais para o desempenho de tarefas remuneradas por produção. Trata-se de atividades eventuais de coletar o coco inteiro e transportá-lo para os fornos. Trata-se de atividades eventuais de coletar o coco inteiro e transportá-lo para os fornos. Tais tarefas são executadas em condições análogas ao trabalho escravo. Os trabalhadores passam dias arranchados nos cocais, sobrevivendo em condições sub-humanas e sem nenhum direito trabalhista assegurado. Imobilizados por dívidas e adiantamentos não tem como resistir a seus contratantes e acabam aceitando toda a sorte de imposições.
} 
sucessivas fracassaram e com elas os anseios de recuperação econômica dos setores ligados à industrialização dos subprodutos do coco babaçu.

As terras em que o projeto da CIT se desenvolvia eram arrendadas, e após o fracasso da iniciativa, os camponeses continuavam a pagar renda para os supostos donos da terra até certo período, ocasião em que, por pressão de uma Associação, firmada pelos moradores da referida propriedade, pressionaram o INCRA/MA a criar o Projeto de Assentamento CIT/ Novo Horizonte, entre os municípios de Timbiras e Codó.

Nas palavras de Antônio, 47:

Eu achei que esse movimento que o povo fizeram para se libertar com essa terra aqui que ninguém sabe se o INCRA ainda vem fazer uma desapropriação ou não, porque a CIT só tem a arrendar, não era dela, aí o dono, eu acho que tá vendendo os pedaços aos poucos, os poucos pedaços que tem, o dono tá vendendo, o INCRA é o dono mesmo, porque, agora só que essa terra aqui, essa parte que nós estamos ninguém sabe como é que vai ficar porque sempre aparece um dono daqui, um dono de acolá, o INCRA nunca pode entrar onde tem duas tribo. Só pode entrar onde tem uma. Não sabe quem é que vai comprar. Mas, nessa daí nós estamos se dando bem, graças a Deus, porque não estamos pagando renda, e nós quebra o coco da gente e vende onde quiser, com a broca da nossa roça pra onde quiser, também não tem cerca, nós cria animais , alguma galinha, um porco, mais no chiqueiro. É desse jeito aí! (Antônio, 47, casado. Testemunho oral obtido no povoado Melancia, Timbiras/MA, em 20/01/2011. Caderno de Entrevistas, p. 234)

O fim da experiência da CIT representou a retomada das terras arrendadas à mesma pelos grandes proprietários de terra e a mobilização camponesa para a ocupação dessas terras, contrariando à lógica rentista de apropriação fundiária no campo, a partir da cobrança anual de renda às famílias que lá moram e retiram o seu sustento.

A organização das famílias camponesas significou ampliar as possibilidades de autonomia e reprodução social da família camponesa na terra, recriando uma experiência social distinta do controle e do mandonismo exercido pelos grandes proprietários de terra no município, pois, segundo o entrevistado 
não estamos pagando renda, e nós quebra o coco da gente e vende onde quiser, com a broca da nossa roça pra onde quiser, também não tem cerca, nós cria animais.

As melhorias para o conjunto das famílias do Projeto de Assentamento CIT/ Novo Horizonte também são referidas na fala de Raimundo:

Pesquisador: E como é que é a vida aqui no Pedra Preta? Seu Raimundo: Aqui é bom. Quando nos vimos para cá, era terreno de dono, não sabe? Aí depois entrou esse negócio de comunidade, e o INCRA desapropriou e botou as família que estava aqui para trabalhar, porque eles tem casa construída, sem ser do INCRA (...)Mas quando nós chegamos aqui, a gente fazia para morar, para pagar renda. Agora ninguém paga renda. Paga um negócio de uma Associação aí, oh, um direito que a gente tem para pagar mais, e aí a terra é nossa que é aqui, para a gente trabalhar, não sabe? Num tá dividida, cada casa seu lote, mais o terreno é para nós explorar, trabalhar. Pesquisador: E o senhor viu alguma diferença de antes para agora? Teve melhora?

Seu Raimundo: Rapaz, até que por umas parte melhorou, mas, por outras, ficou quase na mesma. Mas, por umas parte melhorou. Basta dizer as casas de forno, a moradia, isso aí nós estamos pra melhor, que de primeiro, nós não tinha. A energia, que a gente não tinha também, só chegou agora. Estrada. Quando nós cheguemo para cá era só vareda, varedinha. (Raimundo, 56, casado. Testemunho oral colhido no povoado Pedra Preta, Timbiras/MA, em 20/01/2011. Caderno de Entrevistas, p. 186).

As casas de forno, moradia, energia e estrada foram expressas pelo entrevistado como melhorias criadas no povoado Pedra Preta, após a instalação da Associação dos Produtores Rurais do Povoado Pedra Preta, situada no bairro São Sebastião, em Timbiras. Fundada em 8 de agosto de 2000, hoje integra o Projeto de Assentamento CIT/Novo Horizonte.

O projeto de assentamento CIT/Novo Horizonte é composto por cinco unidades: Corujão, Alto Bonito, Tuturubá, Lagoa da CIT, São José de Pinho, Solobro, Boa Esperança da CIT, Santo Antônio e Pedra Preta, e engloba vários povoados situados entre o município de Timbiras e Codó. Envolve 369 famílias de 
trabalhadores rurais assentados em 8.252 hectares. Em Codó, além do projeto de assentamento mencionado há outros três: Monte Cristo, Raposa e Orcaisa.

Estamos diante da conformação de um processo de territorialização camponesa, em uma lógica distinta daquela experimentada por famílias camponesas sem terra, sujeitas às práticas subordinadas do arrendamento, ou de famílias que residem na cidade, e que passaram por um processo de expropriação do campo, pois ainda, de acordo com Raimundo e Domingas:

Seu Raimundo: Aqui, por em redor, daqui, Salobro, São José do Pinho, pra onde você entrar é comunidade desse tipo que nós tâmo aqui.

Dona Domingas: É Extrema do Bonfim. Do Bonfim é do Leonel, do Biné. Extrema, do Bonfim, fábrica de cimento. Pra cá tudo é comunidade.

Seu Raimundo: Comunidade daí saindo duma tá dando noutra, bem aqui em Santo Antônio, é uma comunidade. Boa Esperança é outra. Entrevero, São José de Pinho, tudo, pra cá onde você entrar é comunidade desse tipo aqui, tá as casa do INCRA desse jeito aqui.

Pesquisador: Tá certo!

Seu Raimundo: Assentado. Os assentado falaram. Terra improdutiva pra trabalhar, só não é pra vender. (Raimundo,56; Domingas 56, casados. Testemunho oral colhido no povoado Pedra Preta, Timbiras/MA, em 20/01/2011. Caderno de Entrevistas, p. 193).

As falas dos entrevistados revelam um território da comunidade, com uma organização agrária distinta de outros segmentos do campesinato regional, e dotadas de certa referência geográfica - pra onde você entrar é comunidade desse tipo que nós tamo aqui; onde saindo duma tá dando noutra - outra territorialidade camponesa.

Os lotes no povoado Pedra Preta, não se localizam junto à morada da família, conforme indicou Raimundo: "Num tá dividida, cada casa seu lote, mais o terreno é para nós explorar, trabalhar". Contudo, os roçados apresentam-se distribuídos de acordo com as necessidades edáficas da cultura agrícola, como podemos observar por meio dos lotes do entrevistado, divididos entre a plantação de arroz, em terreno de barro, mais distante da morada e os cultivos de mandioca, feijão, abóbora, quiabo e melancia plantados em um lote situado mais perto da casa da família, como podemos observar na Figura 5 : 


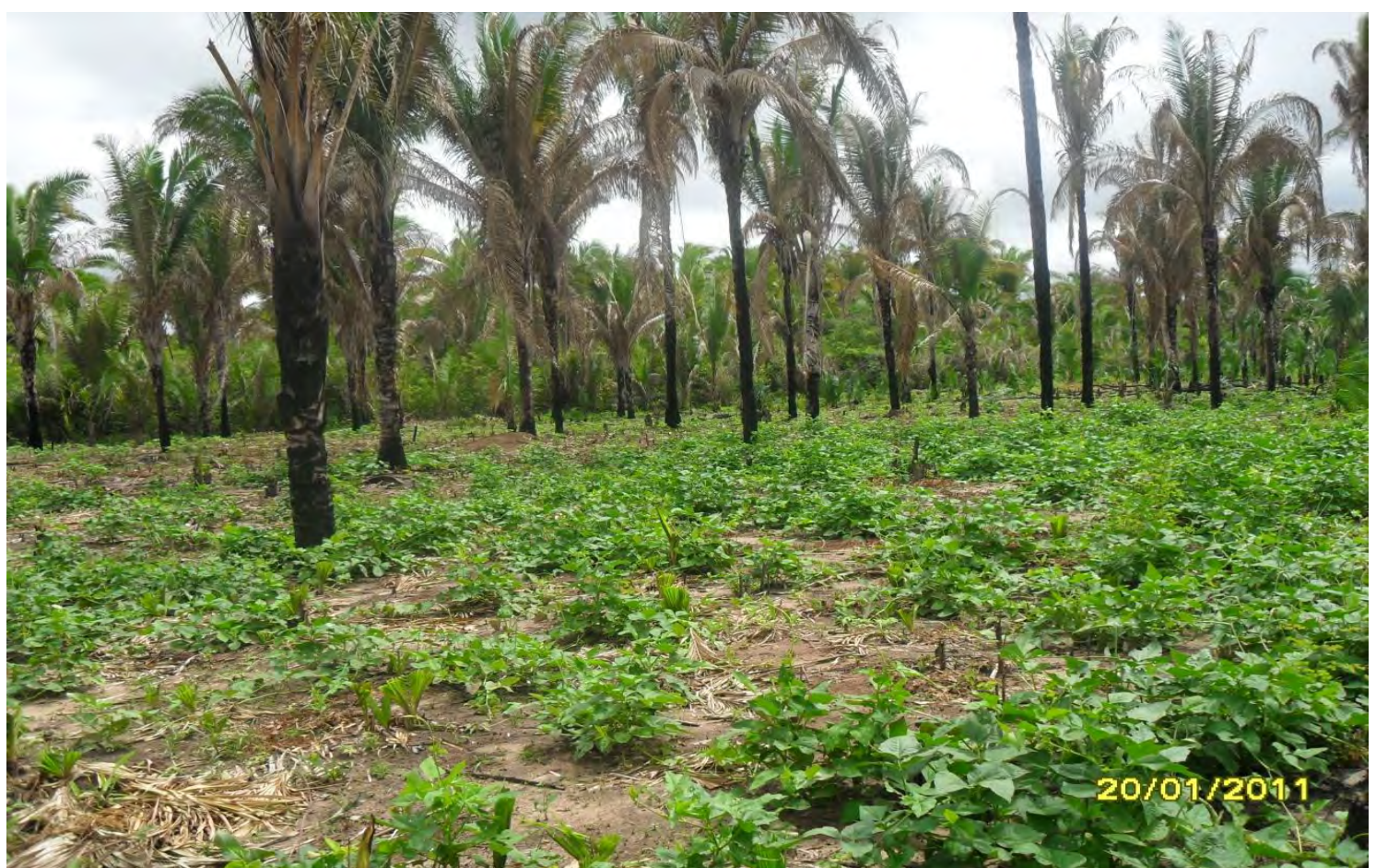

Figura 5 - Roça da família. Cultivos alimentares (feijão) no roçado da família, em meio aos babaçuais, a poucos minutos da morada da família, no povoado Pedra Preta, interior do município de Timbiras/MA.

Foto do autor, 20 de Janeiro de 2011.

A divisão dos lotes das famílias da unidade Pedra Preta do Projeto de Assentamento $\mathrm{CIT/Novo} \mathrm{Horizonte} \mathrm{também} \mathrm{não} \mathrm{reproduz} \mathrm{as} \mathrm{cercas} \mathrm{que} \mathrm{O}$ território do capital impõe ao horizonte da agricultura camponesa e da prática extrativa do coco babaçu. O limite dos lotes é demarcado por tocos e galhos da cobertura vegetal queimados para a formação do roçado, conforme expõe seu Raimundo: "Isso aqui é do bloco. É pau que a gente derruba. É da derrubada. Enfim, aqui é outra esteira, do outro vizinho da roça, tá aqui é outro vizinho. A minha é daqui para trás" . (Raimundo, 56; casado. Testemunho oral colhido no povoado Pedra Preta, Timbiras/MA, em 20/01/2011. Caderno de Entrevistas, p. 209 - 210). Podemos visualizar o testemunho de Raimundo, por meio da Figura 6 : 


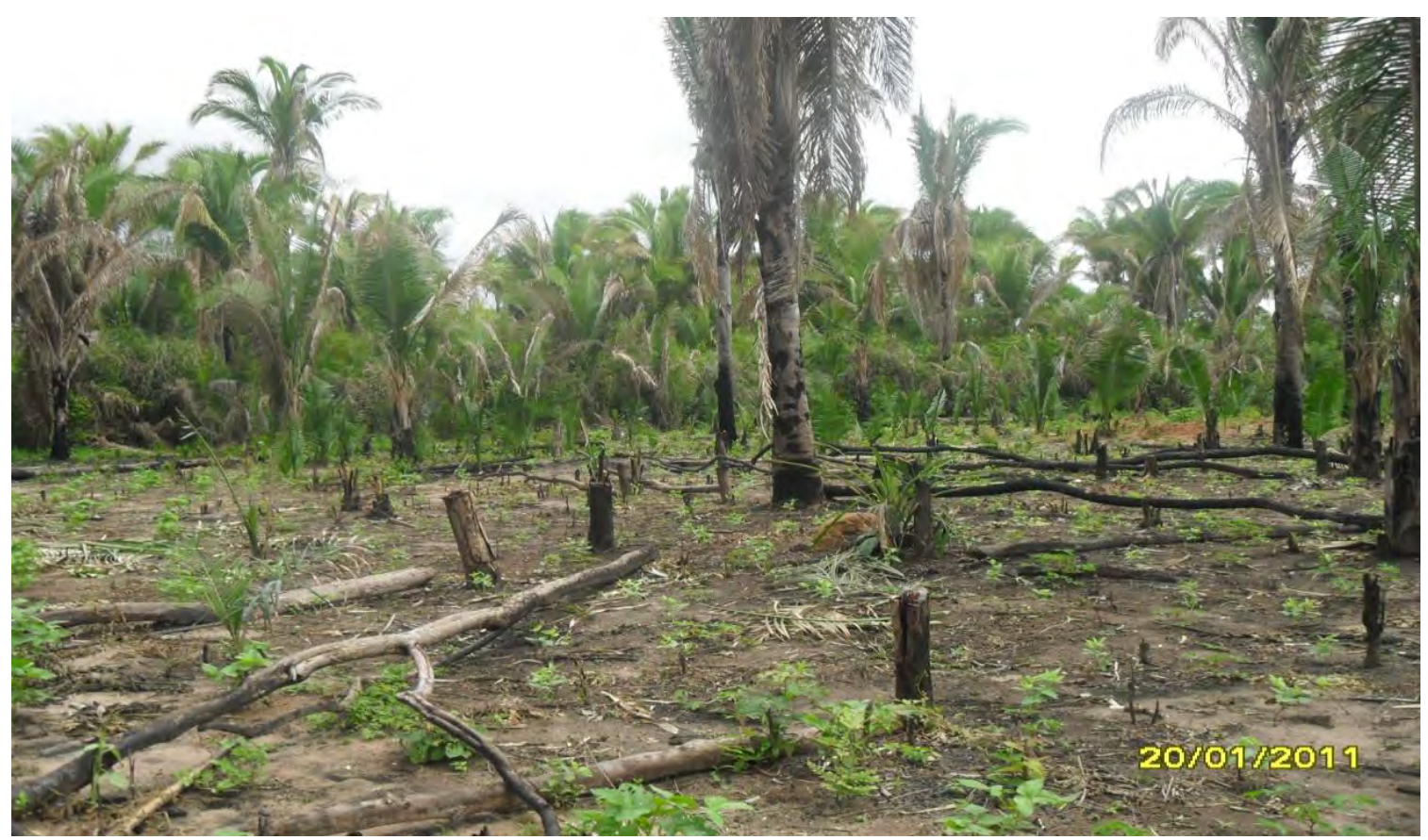

Figura 6 - Divisa. Os tocos cortados e os galhos dispostos horizontalmente são o único marco visível na delimitação dos cultivos familiares. Povoado Pedra Preta, Timbiras/MA.

Foto do autor 20 de Janeiro de 2011.

Na roça de feijão, mandioca, melancia, abóbora e quiabo da família de Raimundo e Francisca, a palmeira de babaçu se faz presente, e fornecem parte dos subprodutos do coco, que são processados, vendidos e aproveitados na própria unidade doméstica, conforme indica Domingas:

Nós trabalha direto. A gente trabalha até tirando o caroço do coco, aí a gente tira o azeite leva pra feira pra vender, a gente faz o carvão da casca pra gente cozinhar o dia a dia. Agora só que tem vez que, tem vez que fracassa, porque eu num güento muito carregar pra casa o coco. Aí eu aproveito os menino quando num tá trabalhando, eu aproveito eles vou no mato, boto em casa e eu quebro. As vezes eu compro um saco, compro dois, quando o meu tá fracassando eu compro pra não faltar. (...) Porque o gás é caro, pra gente cozinhar só no gás é muito caro pra gente cozinhar. $\mathrm{E}$ aí o azeite, a gente vende, a gente tempera com azeite, bota na panela, e aí a gente faz o carvão da casca, aí as vezes a gente leva pra feira. Agora só que se a gente vender o caroço não é muito bom não. Não é bom porque dois quilo de coco você tira um litro de azeite e vende por cinco reais, as vezes, seis, e o quilo de coco é um real e vinte, um quilo de coco.Então um quilo de coco são dois 
litros. Aí quatro litros de coco a gente tira um litro de azeite. O trabalho dobra? Droba, mas a gente tira mais vantagem, no azeite.

(Domingas, 56, casada. Testemunho oral colhido em 20/01/2011, no povoado Pedra Preta, Timbiras/MA. Caderno de Entrevistas, p. 191).

Domingas revela a importância dos subprodutos do babaçu para o consumo e complementação das necessidades da família camponesa. Indica a preferência pela venda do azeite, e não da amêndoa na feira, auferindo um ganho maior com o litro de azeite, comercializado entre cinco e seis reais, do que com a venda do caroço, da amêndoa, que em janeiro de 2011, foi vendido a um real o quilo. A idade da entrevistada, já impõe limites à atividade da quebradora de coco, que conta com o auxílio dos filhos e netos "quando num tá trabalhando, eu aproveito eles vou no mato, boto em casa e eu quebro". As restrições físicas para o exercício das funções de quebradeira de coco são compensadas pela compra ocasional, quando a extração doméstica fracassa, seguindo as orientações de uma economia moral camponesa (THOMPSON, 2005), que neste caso incide em não correr o risco da falta de coco, que de certa forma traria vergonha ${ }^{12}$ para Domingas e para a família camponesa.

A entrevistada também aponta o uso do carvão no aquecimento dos cozimentos, complementando ou substituindo a compra de botijões de gás, pois "cozinhar só no gás é muito caro pra gente cozinhar". Contexto semelhante percebemos por meio da entrevista com Raimunda, que mostrou seu fogão à gás adaptado ao consumo de carvão de coco babaçu. Veja a Figura 7:

\footnotetext{
${ }^{12}$ Vergonha, conforme situação semelhante descrita em Heredia (1979) no que tange à compra da farinha de mandioca na feira por parte da família camponesa.
} 


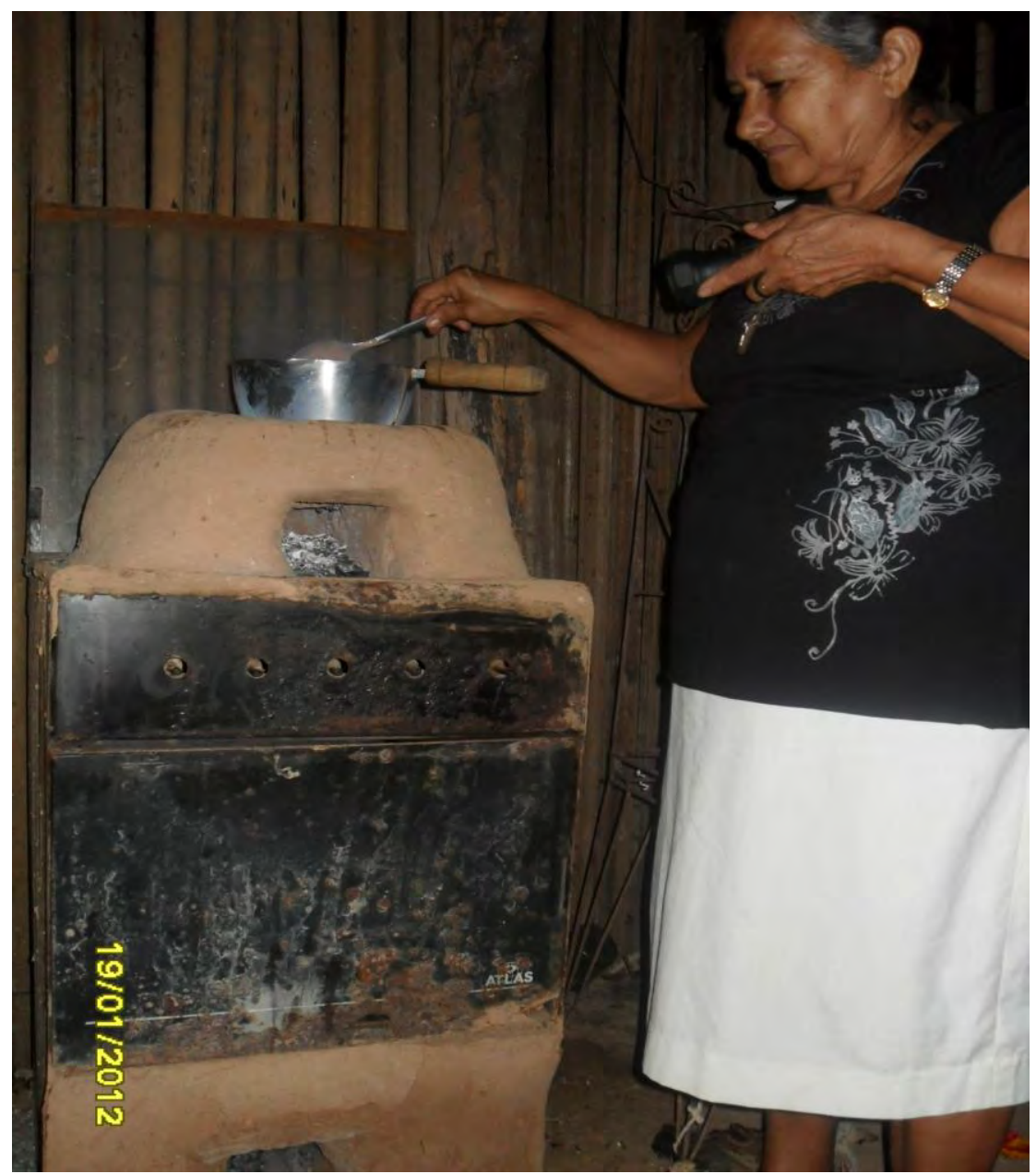

Figura 7 - Cozendo com afeto. Dona Raimunda cozinha o mingau de mesocarpo do coco babaçu, em um fogão de barro erigido sobre uma carcaça de fogão à gás. Ela faz o cozimento do alimento em um "puxado" da casa, sem luz, daí o uso de uma lanterna a pilhas. Bairro São Raimundo, Timbiras/MA.

Foto do autor, 19 de Janeiro de 2011.

O processo de aproveitamento integral do coco babaçu, capitaneado no município de Timbiras, desconsidera todo esse saber fazer e o conjunto de práticas cotidianas da família, que giram em torno da palmeira babaçu. Práticas cotidianas da família, que recriam uma associação íntima dos integrantes da família com as atividades econômicas advindas da utilização dos babaçuais desde a tenra idade, conforme apresenta o testemunho oral de Francisca:

Sim, quando ele estava para São Paulo, nós saía de casa bem cedo, não é? Ele estava lá no interior, não é? Nós saía de casa bem cedo, levando essa meninazinha aí no ombro, não é? Nós saía bem cedo, eu fazia um frito, e aí a gente botava numa marmita lá, e é tirava é para o mato, não é? Levando ela. Nós passava o dia todinho no mato, quebrando 
coco, não é? Uns ajuntava, eu quebrava, outros já botava a casca ali para queimar, no outro dia que a gente fosse, não é. E aí era assim a nossa vida. Sofri muito, você acredita, na primeira vez que ele saiu, eu sofri muito.

(Francisca, 42, casada. Testemunho oral colhido em Timbiras, em 16/01/2011. Caderno de Entrevistas, p. 81)

A migração do marido e do filho para o trabalho nos canaviais paulistas a partir de Guariba, não interrompeu as atividades de quebradeira de coco de Francisca, que preparava antecipadamente o alimento para passar o dia todinho no mato, quebrando coco, na companhia da filha caçula com poucos anos de idade. As dificuldades associadas à ausência do marido se somavam ao trabalho multiplicado de manutenção da pequena produção camponesa, quebradeira de coco e o cuidado com os filhos, causando muito sofrimento esta recém-moradora da cidade de Timbiras.

Em outra ocasião, a companhia dos filhos nas atividades de coleta e quebra do coco babaçu até certa idade, encarregando precocemente os filhos menores na realização de funções requeridas no interior da unidade camponesa, conforme uma divisão sexual do trabalho estabelecida. No excerto abaixo, a entrevistada, ainda revela a preocupação de não sobrecarregar os pais no cuidado dos filhos, comprometendo os já parcos produtos do roçado voltados à alimentação dos integrantes da família.

No coco eu trabalhava, eu quebrava, saía de manhã, seis horas. Sete hora saia pro mato. Ai deixava os cuscuz feito tudo, tudo pro meus filho comer antes de eu sair. Toda a vida eu fui uma pessoa que não esperei por ninguém. Eu nunca deixei meus filho na casa, na minha mãe. Nunca. Eu levava a comadre mais eu. A menina foi crescendo, antes de dez ano de idade, eu deixava ela em casa, ensinava para ela como era. Deixava o cuscuzinho feito, cafezinho fresquinho, porque eu pensava assim: minha mãe tem o que fazer, se eu deixar meus filhos lá, minha mãe não faz o que pra ela comer também, que eu não dava de fazer para eu não dar para ela. Toda a vida foi assim. (Raimunda, casada. Testemunho oral colhido em Timbiras, em 19/01/2011. Caderno de Entrevistas, p. 148) 
Todavia, a predominância do trabalho da mulher na quebra do coco babaçu, não representa o seu afastamento, desde criança do trabalho na roça, como apresenta Domingas:

Pesquisador: E a senhora, não é, trabalha quebrando coco desde quando?

Domingas: Muitos ano, desde menina, que eu me entendi, que eu comecei trabalhando, eu trabalhava junto com a minha mãe, que a profissão é quebrar coco e para trabalhar de roço. Bom, quando eu era mais nova, eu era mais trabalhar na roça. Eu gostava, eu gostava de trabalhar na roça, quando os menino tava desse tamanho assim, aí assim era que eu achava bom, mas aí eu fui fracassando, eu não tinha mais a resistência de trabalhar na roça, aí eu fico só em casa agora, quebrando um quilinho de coco e fazendo a comida pros menino que vão pra roça.

(Domingas, 56, casada. Testemunho oral colhido no povoado Pedra Preta, Timbiras/MA, em 20/01/2011. Caderno de Entrevistas, p. 192).

A quebra do coco babaçu foi demonstrada por Antônia como podemos visualizar na Figura 8:

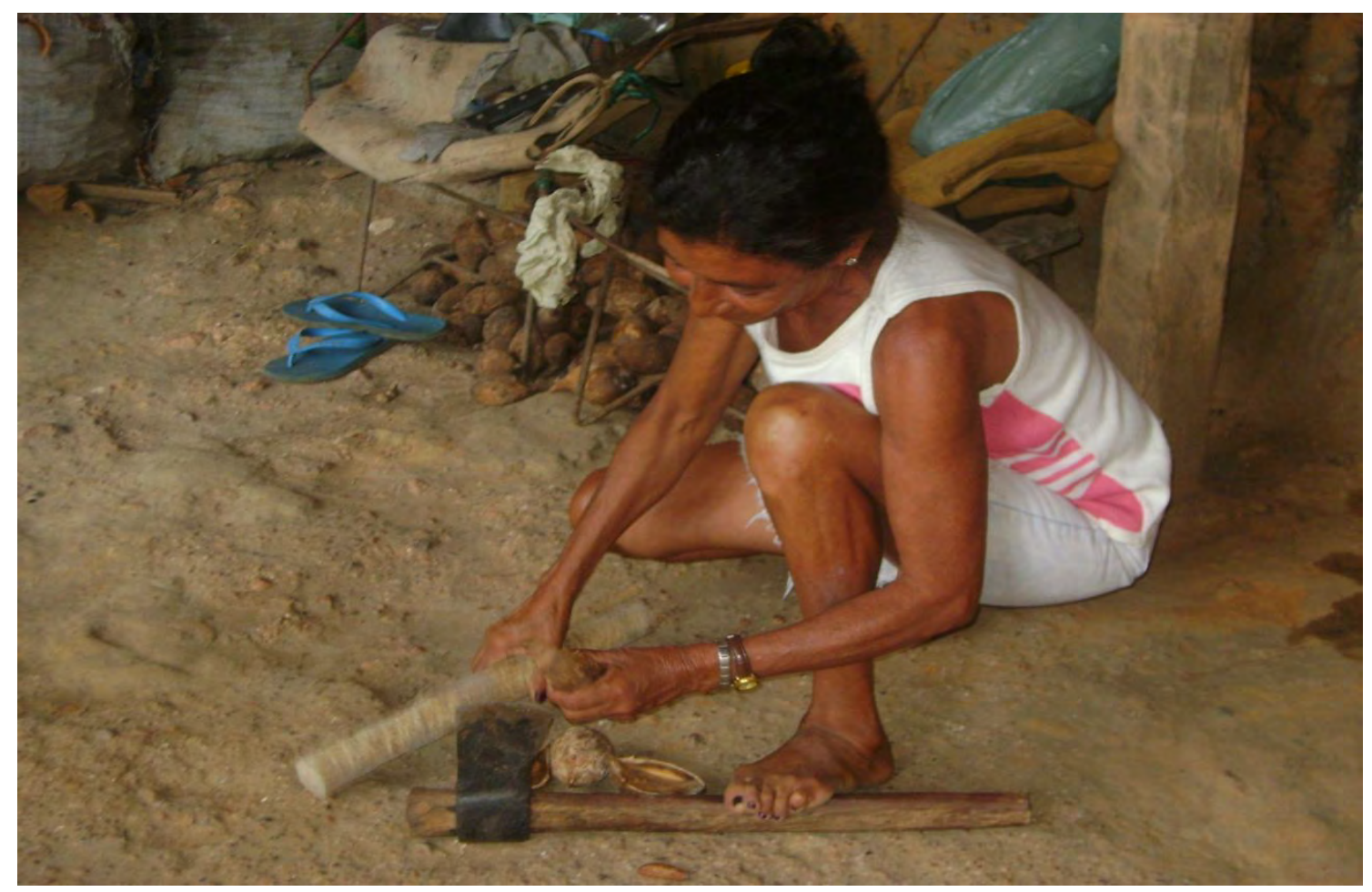

Figura 8 - Quebra do coco babaçu. Antônia, 51, mostra em um puxadinho em sua residência a atividade de quebra do coco babaçu em Codó/MA.

Foto do autor, 9 de Janeiro de 2010. 
O babaçu sustenta todo um conjunto de práticas sociais que alicerçam a constituição histórica do campesinato maranhense. Envolvem um saber fazer que abrange uma gama de produtos, cujo valor de uso reproduz concomitantemente à família camponesa. O saber fazer, nas palavras dos camponeses:

O carvão:

O carvão, a gente bota as casca ali na caieira, assim um buraco no chão, aí queima, e aí depois que ele tá bem queimadinho, a gente vai lá, abafa, bota umas palha, ou o que seja,um estofo, uma esteira, e aí bota na boca da caieira com um pouco d'água, aí é que a gente abafa o carvão e aí tira no outro dia seguinte, não pode tirar no mesmo dia, pra a gente cozinhar, o fogareiro. (Domingas, 56, casada. Testemunho oral colhido no povoado Pedra Preta, Timbiras/MA, em 20/01/2011. Caderno de Entrevistas, p. 206).

Observe a Figura 9:

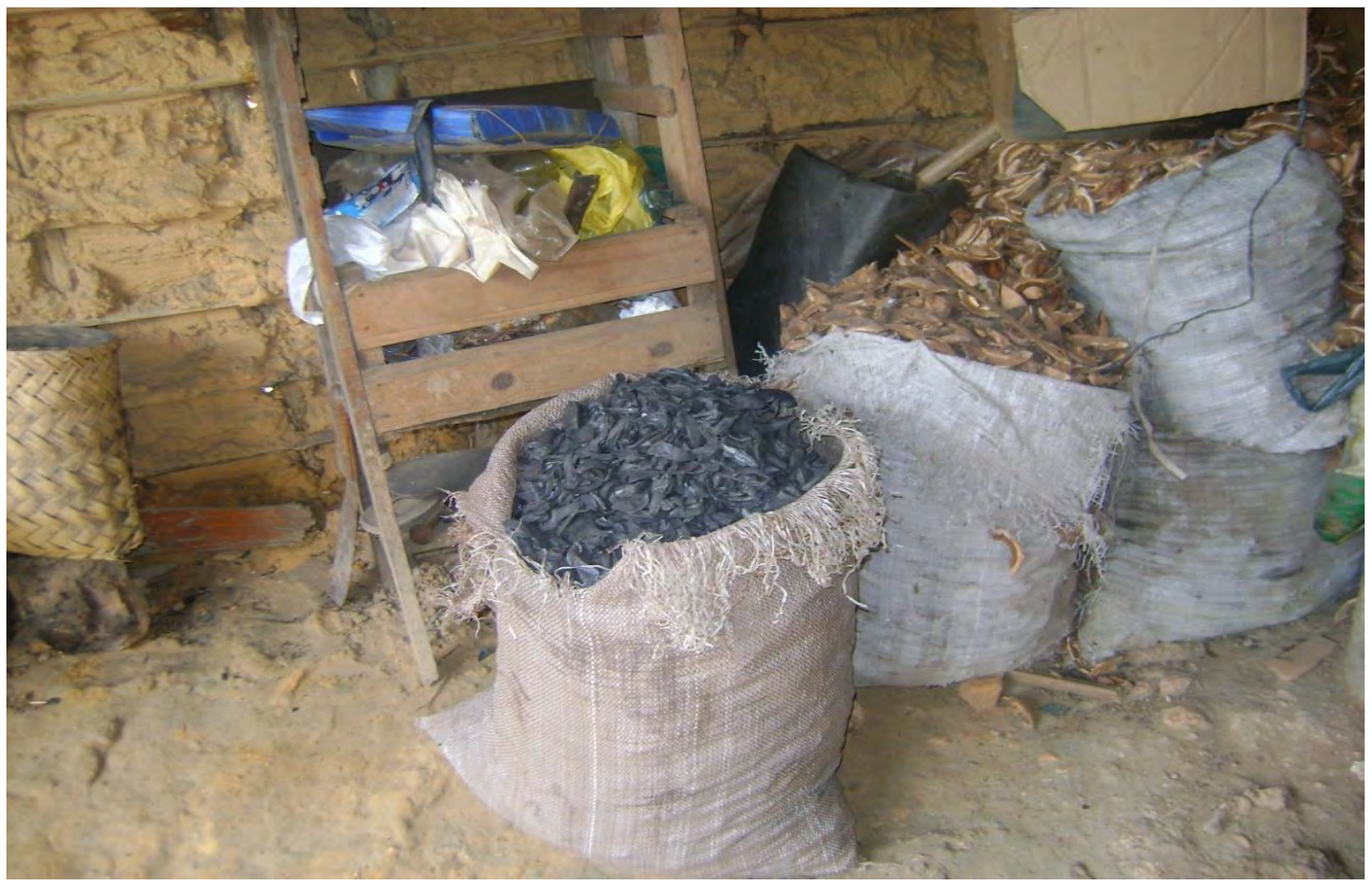

Figura 9 - Coco queimado. Carvão do coco babaçu utilizado para atividades domésticas e também comercializado em Codó/MA.

Foto do autor, 9 de Janeiro de 2010. 
Já o azeite:

A gente quebra ele, tira, tira os carocinho assim, bem limpinho, não pode ter casca, para passar nesse moinho aqui. Aí antes desse moinho, a gente bota ele no pilão, machuca, aí é que bota aqui nesse moinho para passar, para sair só aquela garapa. (...)Aí a gente bota na panela e aí bota umas trempe ali com lenha, panelona bem grande, aí ele vai ferver com água e aí subir o azeite. Quando ele tá aquela borra fica dura no fundo da panela, aí é que a gente tira do fogo, e bota noutra vasilha, que é pra apurar o azeite, que é pra vender. (Domingas, 56, casada. Testemunho oral colhido no povoado Pedra Preta, Timbiras/MA, em 20/01/2011. Caderno de Entrevistas, p. 206).

(Domingas, 56, casada. Testemunho oral colhido em 20/01/2011, no povoado Pedra Preta, Timbiras/MA. Caderno de Entrevistas, p. 206).

Por meio dos testemunhos orais colhidos na atividade de campo pudemos perceber que a territorialidade de "ponta de rua" constituída nos bairros periféricos do núcleo urbano de Timbiras não rompeu os laços e saberes pertinentes ao universo camponês. Se a intensificação da precarização foi sentida pela família de origem camponesa, por meio da expropriação ou das dificuldades advindas do sistema de arrendamento da terra, a migração forçada para a cidade e para o trabalho nos canaviais paulistas não apagou o histórico processo de empobrecimento que experimentam ao longo de suas vidas. A concentração fundiária regional é um dos elementos estruturais, que no dizer de Carneiro et al. (2007) conservam as migrações de trabalhadores maranhenses para o corte de cana em São Paulo. Trataremos desta questão no próximo subcapítulo.

\subsection{A Territorialização do capital e dos conflitos fundiários nas terras concentradas dos babaçuais do leste maranhense}

Incentivos creditícios e fiscais voltados à atividade de criação de gado bovino promoviam gradativamente um processo de pecuarização da economia na região dos Cocais. Com as fazendas de gado, intensificou a retirada da cobertura vegetal em amplas áreas e a escassez crescente das áreas próximas disponíveis para a coleta do coco babaçu. A expulsão de famílias de fazendas de gado, ou a 
apropriação de terras ocupadas por posseiros, incrementou a migração ruralurbana para a sede do município.

Com o crescimento da pecuária, assentada em grandes propriedades rurais, aumenta a procura para o trabalho no desbaste dos babaçuais e das formações de vegetação a ele associada, para a abertura de fazendas e plantio do capim, favorecendo o crescimento de uma modalidade de trabalho degradante em nível regional ou até mesmo extra-regional e interestadual: o "roço da juquira", como indica Moura (2009).

Os projetos agropecuários também foram responsáveis por um conjunto de medidas que resultaram na intensificação da precarização da prática do arrendamento como possibilidade de reprodução social para famílias sem terra, ou daquelas que vieram a perdê-las em função dos processos de expropriação e expulsão do campo.

O fortalecimento da grande propriedade assentada na criação de gado ou como reserva de valor produziu, de forma violenta uma intensa precarização das condições de reprodução social de modalidades relacionadas a um modo de vida camponês, posseiros expulsos de terras devolutas por grileiros, moradores expropriados por fazendeiros, pequenos proprietários de terra ameaçados pelas condições extremas de "precisão". A pecuarização ocorrida na zona do babaçu, na região dos Cocais, e em particular na microrregião geográfica de Codó, encontra-se hoje revestida sob a roupagem do agronegócio da carne, atividade que ganha importância no conjunto da economia regional estadual.

Carneiro (2009, p. 33), ao analisar as transformações ocorridas no campo maranhense entre os censos agropecuários de 1995-1996 e 2006, aponta nas Microrregiões Homogêneas de Codó e Presidente Dutra a "persistência do mecanismo do arrendamento como forma de acesso a terra para agricultores, que perderam suas terras e vivem nas chamadas "pontas de rua" das sedes municipais". O autor ainda argumenta:

Nessas MRHs, a concentração da propriedade da terra e a inexistência de alternativas econômicas importantes à atividade agrícola - salvo o emprego público e algumas atividades industriais de pequena monta - coloca a questão da migração para o trabalho em outros Estados (Pará, São 
Paulo, Goiás, etc.) como a principal fonte de renda para milhares de trabalhadores rurais. (CARNEIRO, 2009, p. 33)

Silva (2010, p. 12) a partir da análise de processos jurídicos levados adiante por 85 camponeses expropriados em 2004, nos municípios de Codó, Coroatá e Timbiras, constata a violência física e simbólica praticada contra famílias de moradores que pagavam a renda em produto e relata a ação violenta de empresa do grupo Maratá, que despejara cem famílias da Fazenda São Raimundo, em 2004, incendiando casas de morada e espalhando medo. Segundo a pesquisadora, o grupo econômico possui atividades relacionadas ao comércio, à agropecuária e a indústria na região Nordeste (SILVA, 2010, p. 12-13), e pudemos constatar este fato em um anúncio publicitário na cidade de Codó, em janeiro de 2000, conforme registra a Figura 10:

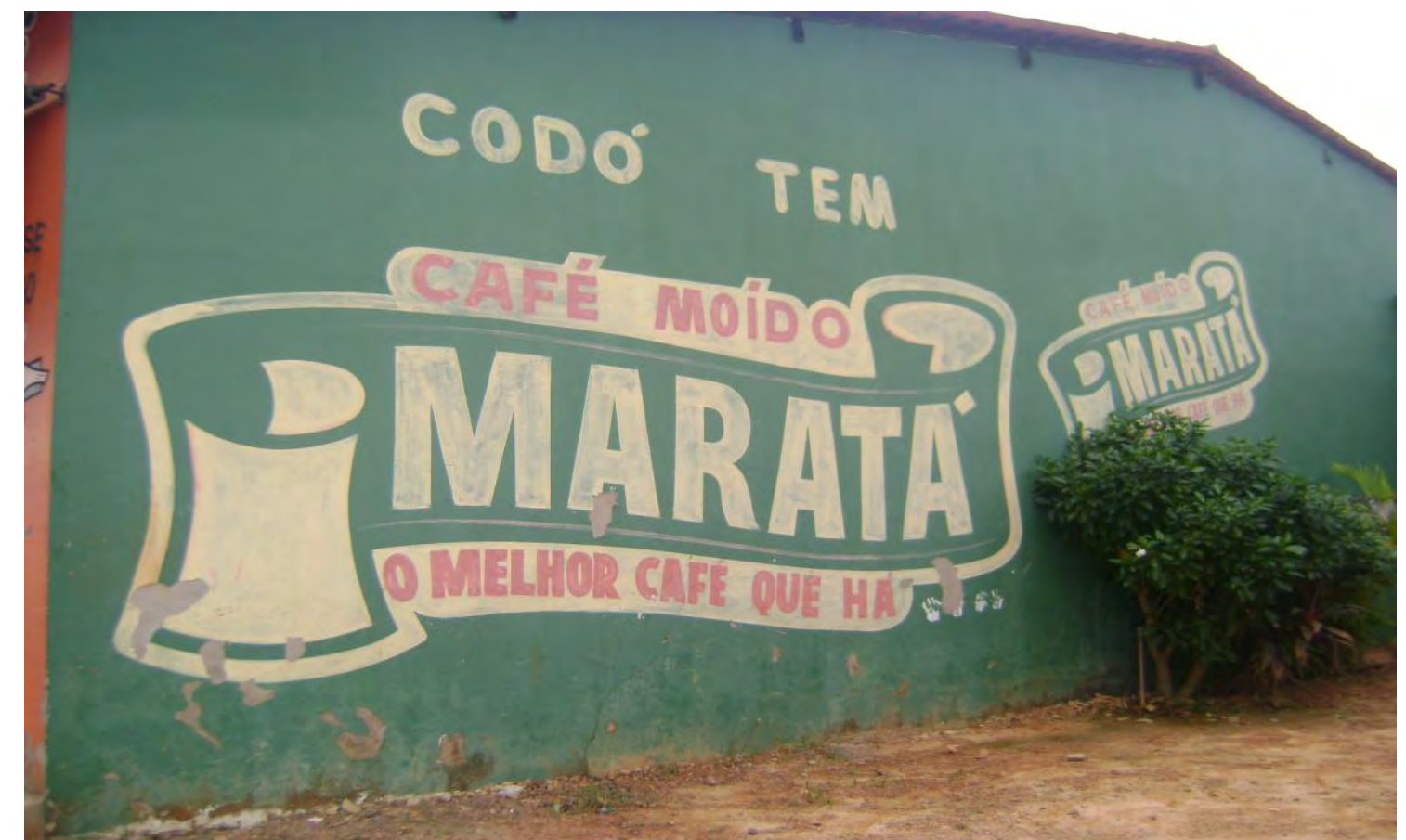

Figura 10 - Publicidade de produto do Grupo Maratá em parede externa de estabelecimento comercial no Bairro São Raimundo, em Codó/MA.

Foto do autor, 9 de janeiro de 2010.

Silva (2010) ainda traz importantes elementos de outra ação violenta perpassada na Fazenda Campestre, em razão dos mandos e desmandos cometidos pela família de proprietários rurais, que controla há gerações o poder político local e é dona de grandes extensões de terra no município de Timbiras. 
No entanto, apesar das ameaças, das práticas desrespeitosas de soltar o gado na roça dos moradores, e da disseminação do medo, a resistência dos camponeses se faz presente.

Quarenta e duas famílias de posseiros da comunidade Conceição foram ameaçadas de expulsão e proibidas de colocarem suas roças em 2009, sofrendo ameaças do proprietário dos três mil hectares de terra, que faz parte de área contínua da fazenda Campestre do Catulo. No quilômetro14, no projeto falido da Agrojaísa, implantado pela SUDENE, 58 famílias acampadas desde 2002, aguardam um novo processo de desapropriação dos 2015 hectares da propriedade, que a empresa obteve de volta a terra em 2006. A fazenda Santana, latifúndio improdutivo de quatro mil hectares foi vendida a um grupo econômico do Estado de Alagoas, que "exige a terra limpa", ou seja, sem as 43 famílias que moram a mais de 50 anos na área. O mesmo grupo econômico adquiriu 1900 hectares de ocupação antiga de posseiros, sendo a comunidade de São Francisco, composta de remanescentes de quilombos. (Fonte: www.blogger.com/feeds. Acesso em 30 Jun 2010).

Como pode se verificar os conflitos no campo não se faz ausente na realidade agrária do município de Timbiras e na microrregião de Codó, no leste maranhense, processo este, que na fala de Antônio, produziu uma intensa migração do campo para a cidade.

O que aconteceu foi assim que grandes donos de terra, não é, venderam, digamos assim as terras, que os trabalhadores trabalhavam, porque sempre trabalharam de forma arrendada as terras, não é? Porque todo mundo tem terra, não é menos os trabalhadores, digamos assim, menos favorecidos, não é, trabalhadores rurais, mas sempre tem os grandes donos de terra, não é, os grandes proprietários de terra, começaram a vender as suas terras para outras pessoas de fora, não é, e essas pessoas que vem de fora, não queriam ninguém trabalhando e nem morando nessas terras, não é, e então tiveram que expulsar essas pessoas, não é? Essas pessoas vinham para a cidade, e aí começaram o inchaço urbano, não é, e aí trabalhão o que aqui na cidade? O pessoal da cidade já não tem emprego, e vem o pessoal do interior que vem trabalhar na cidade, aí uma das formas foi: ó fulano, lá em São Paulo, tá tendo dinheiro, no corte de cana. Eu vou para o corte de cana, não é, vou trabalhar fora cortar cana, porque eu já não tenho a 
minha terra para trabalhar aqui e se trabalha é de forma escrava também, não é, aí começou então a migrarem, não é, a viajar aí para fora, para trabalhar, para comprar um terreno na próxima cidade ou na cidade para fazer a sua casa, começou assim, não é. Teve casa que tocaram até fogo nas casas do pessoal que morava no interior para expulsar mesmo das terras e a partir disso também começou a ser criadas também as associações, não é? Já tinha algumas, mas não tão fortes como se tem agora, não é, que é para justamente contrabater esta questão dos grandes donos de terra, não é? Porque o pessoal tem direito a terra para trabalhar, não é, as terras. Tem terras do governo, que é para trabalhar, mas tem pessoas que querem se apossar dessas terras, não querem deixar as pessoas trabalharem, não é? As associações foram criadas para tentar amenizar isto, não é, amenizar essas coisas, não é. (Antônio, 24, solteiro. Testemunho oral colhido em Timbiras/MA, em 18/01/2011. Caderno de Entrevistas, p. 121 - 122).

Desde o início dos anos 2000, de acordo com o relatório anual Conflitos no Campo, divulgado pela Comissão Pastoral da Terra, há o registro de conflitos por terra no município de Timbiras desde 19 de agosto de 2002, envolvendo posseiros em 14.000 hectares da fazenda Campestre Catulo e 26 famílias de posseiros dos povoados Abundância e Santa Vitória, em 17 de junho de 2002, nos 23.000 hectares em processo de desapropriação (CPT, 2003, p. 42). No que reporta aos anos de 2009 e 2010, o Maranhão concentrou parte significativa das famílias e municípios envolvidos nos conflitos por terra no Brasil, com destaque para a microrregião geográfica de Codó, conforme podemos verificar no Mapa 4. 
Mapa 4 - Brasil: Conflitos por terra (2009).

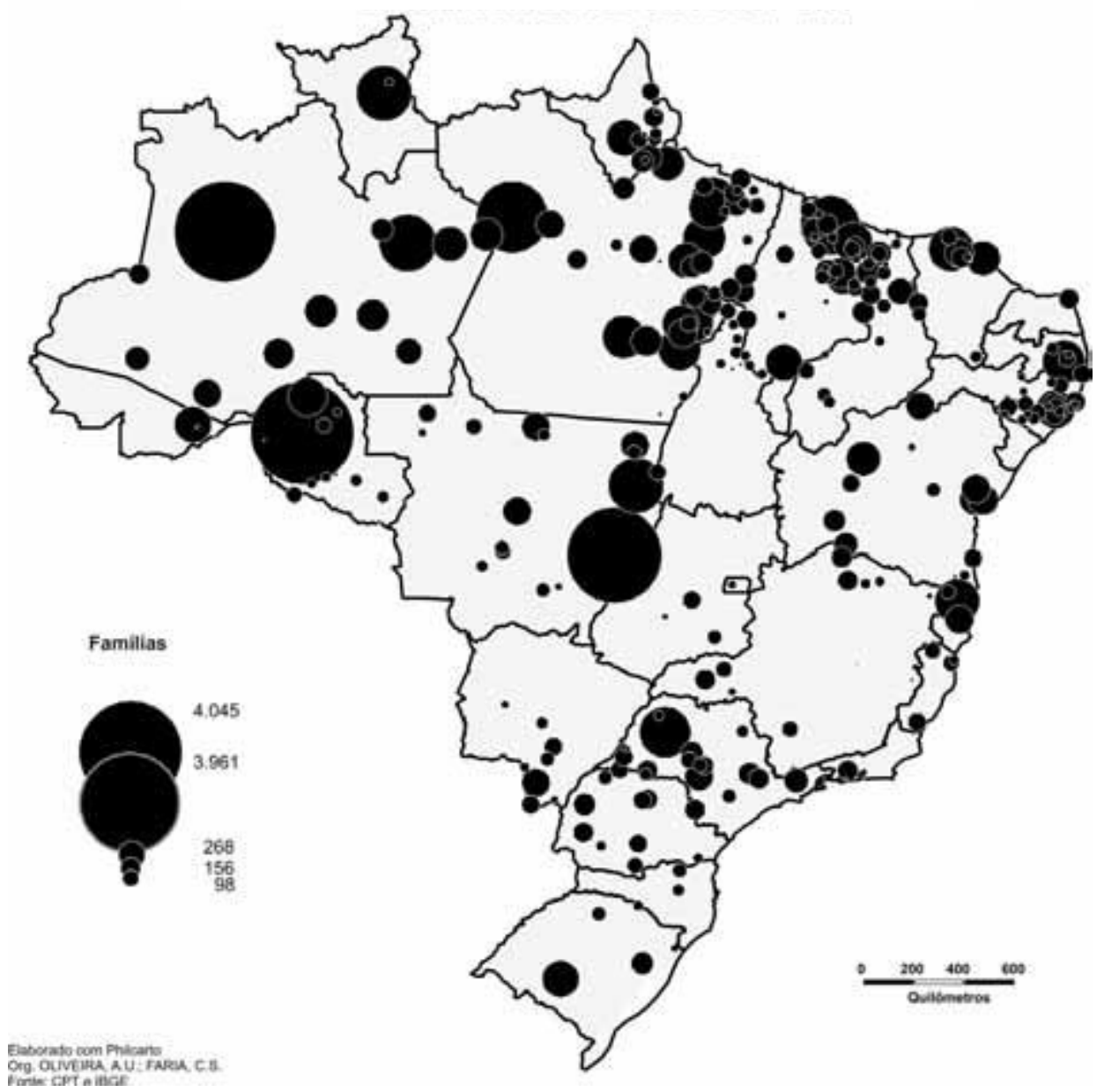

Fonte: COMISSÃO PASTORAL DA TERRA Conflitos no Campo Brasil 2010.

No Mapa 4, nota-se um predomínio do número de famílias envolvidas em conflitos fundiários no campo do Maranhão em uma região constituída pelas mesorregiões geográficas do Norte e do Leste Maranhense, com uma concentração numérica em municípios da Baixada Maranhense. Percebem-se também conflitos que delimitam a região tocantina e o município de Balsas, no sul do Estado como as áreas com o maior número de conflitos no campo maranhense, em 2009. No contexto nacional, a quantidade de famílias envolvidas em conflitos por terra é maior nos Estados de Rondônia, Amazonas, Mato Grosso e Pará. O Estado do Maranhão se destaca pela quantidade de municípios com a presença de famílias envolvidas em conflitos de terra, em 2009. No ano seguinte, o registro do número de famílias associadas à conflitos por terra se estendia a quase todo o Estado do Maranhão. Observe o Mapa 5: 
Mapa 5 - Brasil: Número de Famílias Envolvidas em Conflitos por Terra (2010).

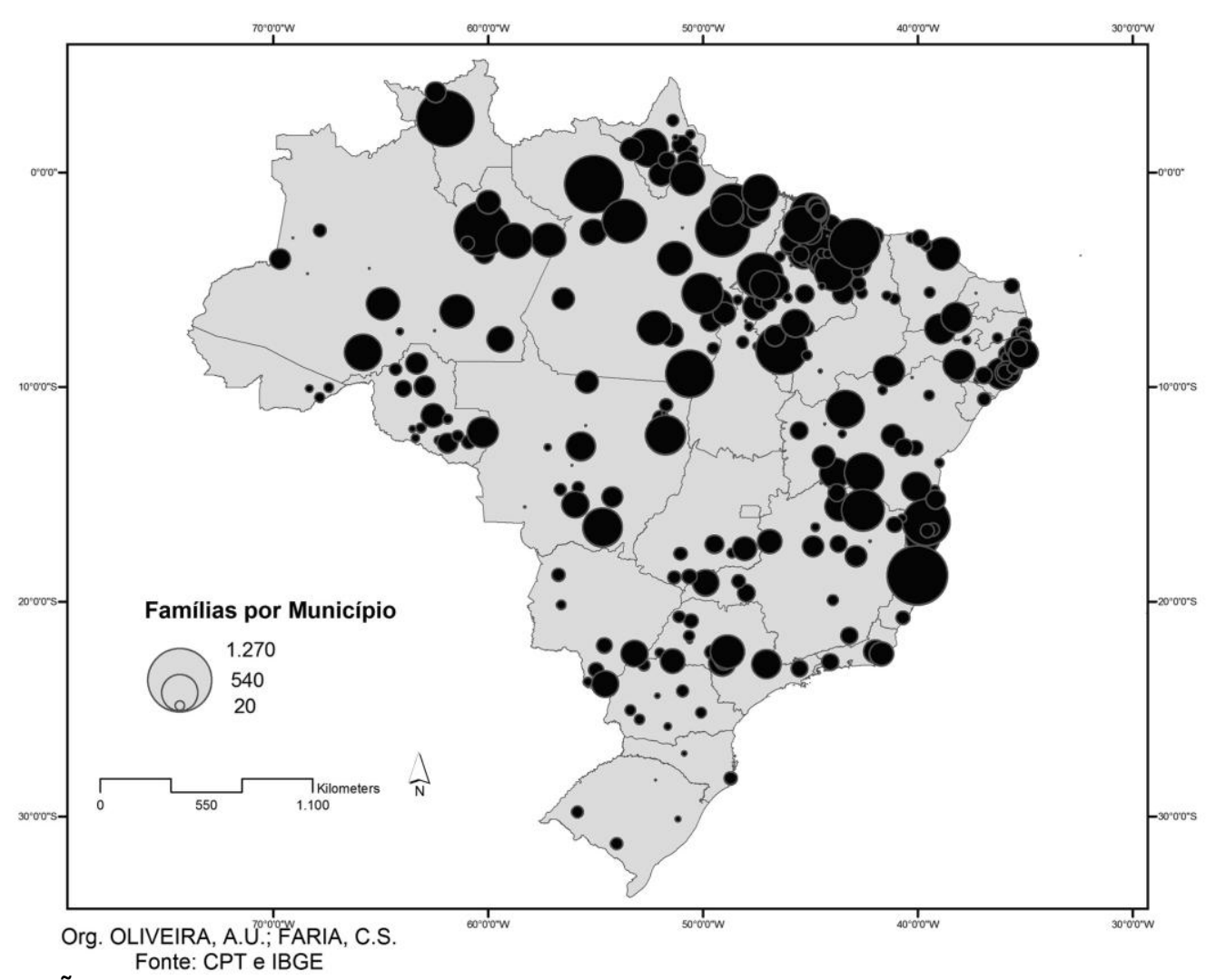

Fonte: COMISSÃO PASTORAL DA TERRA Conflitos no Campo Brasil 2011.

O Mapa 5 revela um aumento do número de famílias envolvidas em conflitos por terra em 2010 no país, apesar de alguns Estados exibirem municípios com uma concentração menor de famílias associadas a conflitos fundiários em relação ao ano anterior. No Maranhão registrou-se uma elevação do número de famílias e de municípios abarcados em conflitos por terra, com destaque para os municípios da microrregião geográfica de Imperatriz, Balsas e Baixo Parnaíba.

A microrregião geográfica de Codó também apresentou vários municípios com ocorrência de famílias envolvidas em conflitos por terra em 2010. Já no que reporta ao número de conflitos, por município, em 2010, verifica-se a concentração de municípios com uma grande concentração de conflitos por terra no Brasil em uma área que abrange o sudeste e parte do leste do Amapá, a região do Bico do Papagaio e o nordeste e quase todo o norte do Maranhão, de forma expressiva, aí incluindo a microrregião geográfica de Codó e o município de Timbiras. Observe o Mapa 6. 
Mapa 6 - Brasil: Número de ocorrências em conflitos por terra (2010).

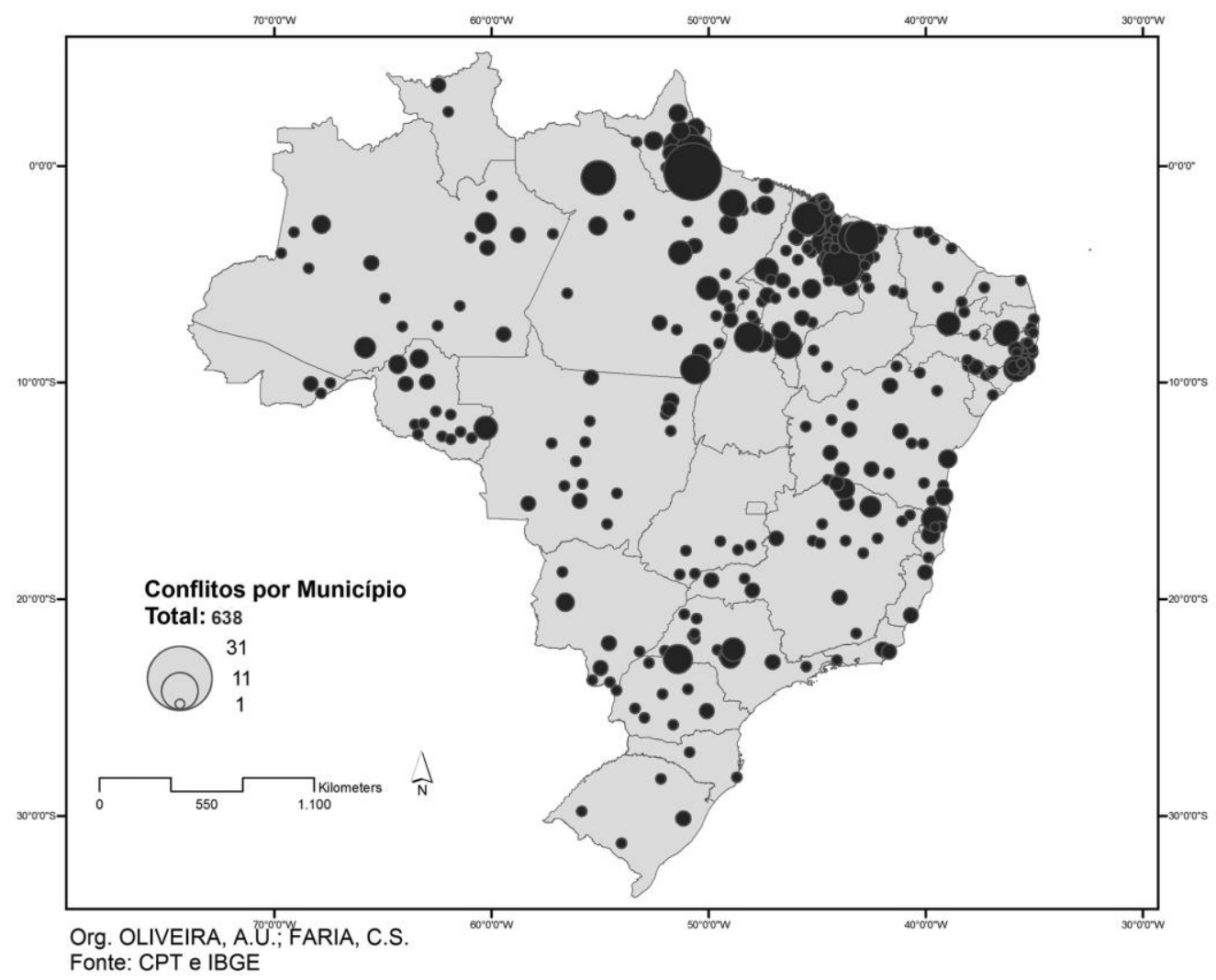

Fonte: COMISSÃO PASTORAL DA TERRA Conflitos no Campo Brasil 2011.

Segundo os Mapas 4, 5 e 6, houve um crescimento importante no número de famílias envolvidas em conflitos de terra no Estado do Maranhão entre os anos de 2009 e 2010 e na quantidade de conflitos por município no último ano. De acordo com os dados da CPT, o Estado apresentou 5.702 famílias envolvidas em conflitos por terra, em 2009, número este que se elevou de forma significativa no ano seguinte, abrangendo 13.071 famílias, um aumento de $229,2 \%$.

No ano de 2009, 954 famílias da microrregião geográfica de Codó, estavam envolvidas em 13 dos 69 conflitos por terra registrados no Estado, o que representa $16,7 \%$ das famílias envolvidas e $18,7 \%$ do número de conflitos no Estado. Neste período, nota-se a quantidade expressiva de famílias associadas a conflitos de terra no município de Timbiras. Trezentas e cinquenta famílias de posseiros estavam ligadas a um único conflito de terra no município, a fazenda Campestre do Catulo, referida anteriormente. Trata-se do conflito por terra com a maior quantidade de famílias envolvidas na microrregião geográfica de Codó, que 
representa $36,7 \%$ do número de famílias da área em tela. Observe os dados da Tabela 4:

Tabela 4 - Microrregião geográfica de Codó/MA : Conflitos por Terra (2009).

\begin{tabular}{|c|c|c|c|}
\hline Município & Localização do conflito & Famílias & Tipo de conflito \\
\hline \multirow{3}{*}{$\begin{array}{c}\text { Alto Alegre } \\
\text { do Maranhão } \\
\text { (3) }\end{array}$} & $\begin{array}{l}\text { Com. Quilombola Marmorana / } \\
\text { Boa Hora } 3\end{array}$ & 22 & $\begin{array}{l}\text { Remanescentes de } \\
\text { quilombos }\end{array}$ \\
\hline & $\begin{array}{l}\text { Gleba Campo do Bandeira / } \\
\text { Companhia Caxuxa Pastoril }\end{array}$ & 70 & Posseiros \\
\hline & Boa Hora 1 & 59 & Posseiros \\
\hline \multirow{6}{*}{$\begin{array}{l}\text { Codó } \\
(6)\end{array}$} & Mata Virgem & 25 & Posseiros \\
\hline & $\begin{array}{l}\text { Fazenda São João / Com Todos } \\
\text { os Santos }\end{array}$ & 35 & Posseiros \\
\hline & $\begin{array}{l}\text { Comunidade Quilombola Cipoal } \\
\text { dos Pretos }\end{array}$ & 30 & $\begin{array}{l}\text { Remanescentes de } \\
\text { quilombos }\end{array}$ \\
\hline & $\begin{array}{l}\text { Fazenda Salva Terra / Com. } \\
\text { Santa Rita dos Moisés }\end{array}$ & 70 & Posseiros \\
\hline & $\begin{array}{l}\text { Povoado Vergel/Vergel/Fazenda } \\
\text { Boa Esperança }\end{array}$ & 80 & Posseiros \\
\hline & $\begin{array}{l}\text { Povoado Buriti Corrente / TG } \\
\text { Agroindústria }\end{array}$ & 140 & Posseiros \\
\hline \multirow{2}{*}{$\begin{array}{l}\text { Coroatá } \\
\text { (2) }\end{array}$} & Santana & 43 & Posseiros \\
\hline & Comunidade Salgado & 30 & Posseiros \\
\hline $\begin{array}{l}\text { Timbiras } \\
\text { (1) }\end{array}$ & Fazenda Campestre Catulo & 350 & Posseiros \\
\hline MRH Codó & 12 & 954 & \\
\hline MARANHÃO & 69 & 5.702 & \\
\hline
\end{tabular}

Fonte: CPT Conflitos no Campo Brasil 2009, p. 35 - 36. Org: SILVA, A. E. R (2012).

A Tabela 4 aponta também que a maior parte dos conflitos por terra na microrregião geográfica de Codó em 2009 envolvia famílias posseiras: 5650 das 5.702 da área analisada, o que corresponde a 99,1\% do total de famílias. Havia o registro de conflitos em 4 dos 6 municípios da MRG, de Codó, sendo que o mais 
importante núcleo regional apresentou 6 dos 13 conflitos por terra no período, o que equivale a $46,1 \%$ do total de conflitos.

$\mathrm{Na}$ microrregião geográfica de Codó, em 2009, a maior parte das ocorrências e das famílias envolvidas em conflitos por terra era representado por posseiros. Em sua maioria, esses conflitos se desenvolviam no município de Codó (6 dos 13 casos registrados), enquanto que a maior parte das famílias envolvidas alocavam-se nesse município e no município de Timbiras, cada um apresentando 350 famílias envolvidas em conflitos pela posse da terra, sendo o último caso, o maior exemplo isolado.

Estes indicadores vão ao encontro das considerações de Oliveira (2011, p. 56) acerca da importância dos posseiros na luta pela terra no Brasil, em reação às Medidas Provisórias 422 (Lei $n^{\circ} .11 .763$ - 01/08/2008) e 458 (Lei $n^{0} 11.952$ 25/06/2009), pois, segundo o autor:

ampliou as possibilidades de regularização da grilagem da terra pública rural e urbana na Amazônia Legal. Como consequência, ao invés do Incra fazer o terceiro plano de reforma agrária, o MDA criou o Programa Terra Legal, para regularizar as terras públicas do Incra, griladas pelo agronegócio. (...).

Em decorrência dessa política, os conflitos por terra aumentaram, particularmente na Amazônia Legal, e com eles os posseiros foram em 2010, os principais protagonistas da luta pela terra no país, ultrapassando as ações dos SemTerra.

A partir das considerações de Oliveira (2011, p. 56) é possível compreender o predomínio dos posseiros, e também dos posseiros quilombolas entre as famílias envolvidas em conflitos por terra na microrregião geográfica de Codó, e em particular do município de Timbiras. Observe o Mapa 7. 
Mapa 7 - Brasil: Sujeitos Sociais Envolvidos em Conflitos por Terra (2010).

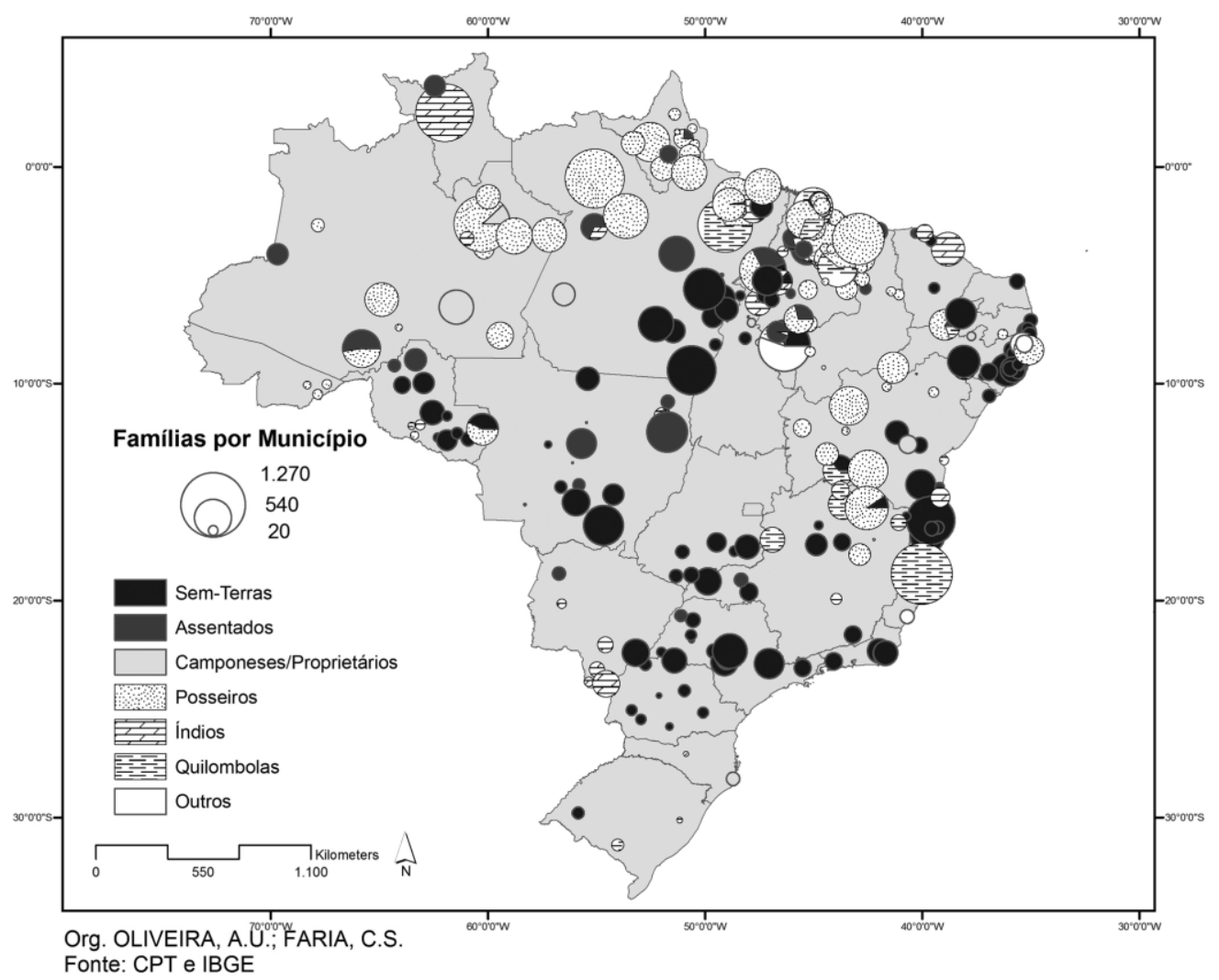

Fonte: COMISSÃO PASTORAL DA TERRA Conflitos no Campo Brasil 2011.

A partir da leitura do Mapa 7, é possível verificar a importância absoluta e relativa dos posseiros nos conflitos por terra em diversos municípios das regiões Norte (com destaque para Estados do Pará, Amazonas e Amapá), Nordeste (especialmente municípios do sudoeste, oeste e noroeste da Bahia, porções de Pernambuco, Ceará e Paraíba, e no nosso caso em particular áreas municipais do leste, sudeste, além de partes da região tocantina e da Pré-Amazônia maranhense) e também áreas do nordeste do Estado de Minas Gerais, no Sudeste.

De acordo com os dados apresentados pelo relatório da CPT, Conflitos no Campo 2010, muitos municípios da porção leste e nordeste do Estado do Maranhão apresentam um grande número e volume de famílias de posseiros envolvidas em conflitos de terra, como as que se situam em Santa Quitéria do Maranhão (10 conflitos e 786 famílias de posseiros), Urbano Santos (9 conflitos e 287 famílias de posseiros), Chapadinha (4 conflitos e 172 famílias de posseiros), 
Milagres do Maranhão (2 conflitos e 157 famílias de posseiros), Coroatá (2 conflitos e 101 famílias de posseiros) e Timbiras (1conflito e 350 famílias de posseiros). Os municípios de Santa Quitéria do Maranhão, Urbano Santos, Chapadinha e Milagres do Maranhão apresentaram também durante os anos 2000, um incremento considerável da área plantada de soja no Leste Maranhense ${ }^{13}$.No entanto, os conflitos fundiários na microrregião de Chapadinha são decorrentes da implantação, a partir da década de 1980, dos chamados projetos de manejo florestal sustentado ${ }^{14}$, destinados à plantação de eucalipto para a produção de celulose e de carvão vegetal, este último destinado ao Programa Grande Carajás. (GASPAR, 2010, p. 67). Acerca da expansão da sojicultura no Leste Maranhense, assim coloca Gaspar (2010, p. 30):

\begin{abstract}
A aceleração da produção da soja no Leste maranhense, somente aconteceu no final dos anos 1990, favorecida pela vinculação de certas condições que, em termos gerais, seriam a facilidade de compra de terras a preços irrisórios, proximidade a portos (como o Porto do Itaqui, em São Luís) para escoamento da produção a ser exportada e ambiente biofísico favorável, vista a presença de áreas do bioma cerrado.
\end{abstract}

Por razões diversas, a luta pela terra das famílias de posseiros vão de encontro à extrema concentração fundiária existente nestes municípios e nesta porção do Estado, em particular, que não foge a trágica concentração fundiária compartilhada pela esfera maranhense e brasileira, conforme pode ser observada pelo Mapa 8.

\footnotetext{
13 Os chamados gaúchos apropriaram-se das chapadas que, logo à chegada deles, foram vendidas a preços baixos. Nas chapadas, esses agentes utilizam a técnica do correntão, ou seja, tratores de esteira que carregam na parte inferior grandes correntes destinadas à derrubada da vegetação nativa por onde passam. (...). Devido à diminuição das árvores e arbustos nativos, as familias camponesas gradativamente vem se desfazendo das atividades realizadas nas chapadas e que integravam sua economia, como a quebra de coco babaçu e a coleta de bacuris, pequis e outros frutos nativos. (...). (GASPAR, 2010, p. 66)

${ }^{14}$ Os projetos de manejo florestal sustentado, na prática acabavam servindo de fachada para o açambarcamento de grandes extensões de terra nos cerrados do Leste Maranhense, marcando nessa região um processo de grilagem das chapadas com a presença maciça dos chamados latifúndios por exploração, e intenso desmatamento e destruição de recursos nativos. (...). (GASPAR, 2010, p. 68)
} 
Mapa 8 - Brasil: Índice de Gini da área total dos estabelecimentos agropecuários, por município (2006).

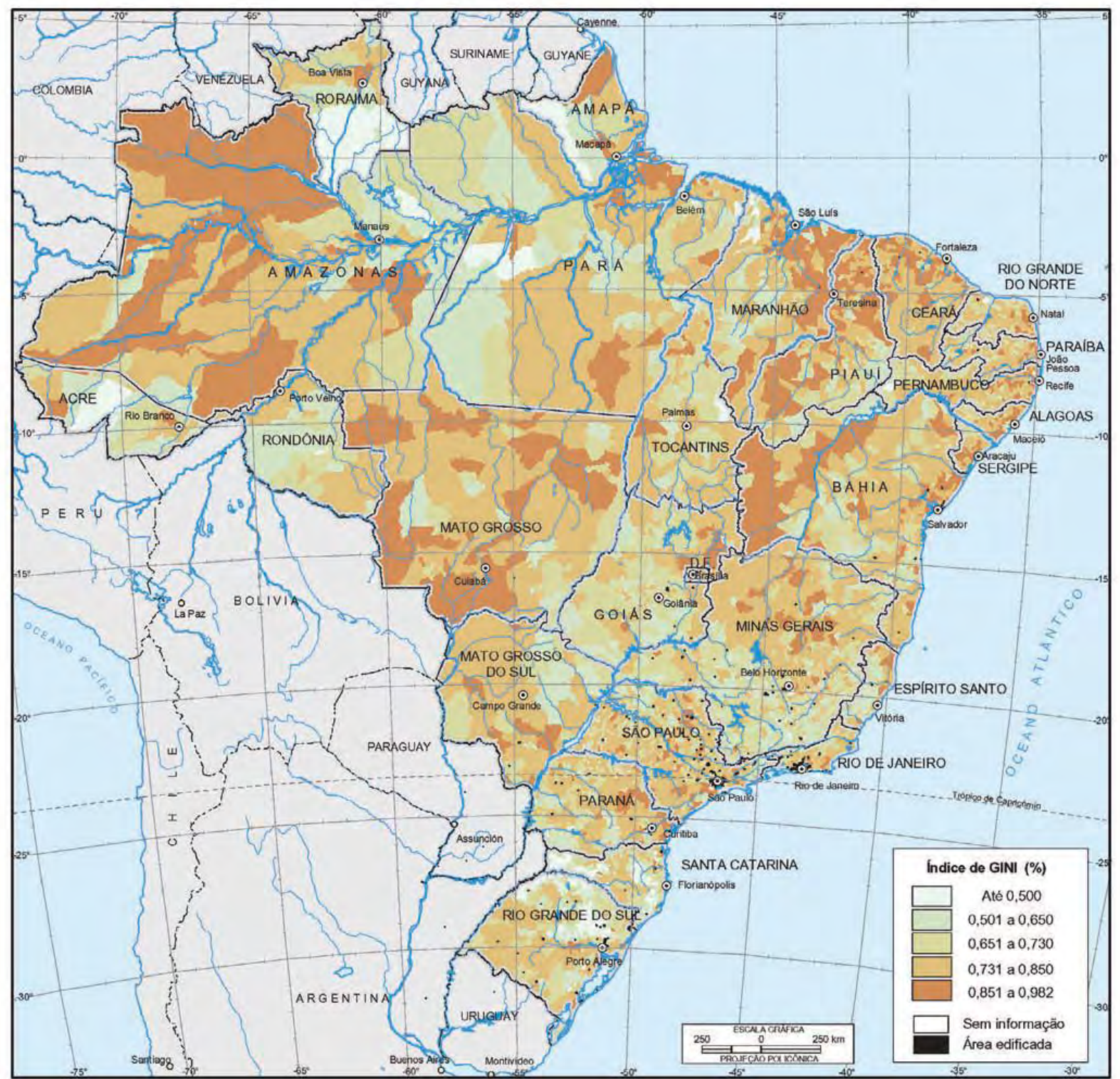

Fonte: IBGE. Censo Agropecuário 2006. Brasil, Grandes Regiões e Unidades da Federação. Rio de Janeiro: 2009. P. 113.

Por meio da observação do Mapa 8, percebe-se a grande concentração de terras no leste do Estado do Maranhão, com o predomínio do estrato entre 0,851 a 0,982, o que revela uma extrema concentração fundiária. O mesmo vale para o conjunto do Estado, o que o posiciona em terceiro lugar $(0,864)$ entre as unidades da federação, que possui a maior concentração fundiária, superada apenas pelos Estados de Alagoas $(0,871)$ e Mato Grosso $(0,865)$ (IBGE, 2009, p. 109) A concentração de terras espraia-se também para a realidade agrária da 
microrregião geográfica de Codó e para o município de Timbiras, como veremos mais adiante.

Depois de minimamente ponderar sobre os conflitos fundiários e da importância da organização dos posseiros na luta pela terra no Brasil, vamos debruçar agora sobre as tensões no campo que afetam a região na qual se encontra o município de Timbiras, a microrregião homogênea de Codó. Observe a Tabela 5:

Tabela 5 - Microrregião geográfica de Codó/MA e Estado do Maranhão: Agentes sociais, Número de Ocorrências e de Famílias Envolvidos nos Conflitos de Terra (2009).

\begin{tabular}{|c|c|c|c|c|c|}
\hline $\begin{array}{c}\text { Agentes } \\
\text { Sociais }\end{array}$ & Região & \multicolumn{2}{|c|}{ Número de Ocorrências } & \multicolumn{2}{|c|}{ Número de Famílias } \\
\cline { 4 - 7 } & & Total & \% dos conflitos na área & Total & \% das famílias na área \\
\hline Posseiros & MRG Codó & 10 & 83,3 & 902 & 94,6 \\
\cline { 2 - 6 } & Maranhão & 35 & 50,7 & 1954 & 34,3 \\
\hline Quilombolas & MRG Codó & 2 & 16,7 & 52 & 5,4 \\
\cline { 2 - 6 } & Maranhão & 20 & 29 & 532 & $9,3 \%$ \\
\hline
\end{tabular}

Fonte: CPT Conflitos no Campo Brasil 2009, p. 35 - 36. Org. SILVA, A. E. R. (2012).

Percebemos, por meio da Tabela 5 que a maior parte dos conflitos e das famílias envolvidas em conflitos por terra na MRG de Codó em 2009 era representada pelos posseiros. Dos 12 conflitos por terra que ocorriam na microrregião geográfica no período, 10 , ou seja, $83,3 \%$ do conjunto referiam-se aos agentes sociais supracitados. O mesmo vale para as 902 famílias de posseiros entre as 954 abrangidas nos conflitos por terra na microrregião geográfica.

Foi possível também conectar a participação importante dos posseiros, no total de conflitos e no de famílias em conflito por terra no Maranhão no ano de 2009. Dos 69 conflitos por terra registrados no Estado 35 envolveram posseiros, o que corresponde a $50,7 \%$ do total de conflitos. No que tange à quantidade de famílias envolvidas em conflitos por terra no Estado, 1954 de um universo de 5702 , isto é, $34,3 \%$ do conjunto de famílias eram representadas pelos posseiros. 
Esses dados revelam que a região, na qual se encontra o município estudado no Maranhão, apresenta uma grande quantidade de conflitos e de famílias envolvidas na luta pela terra, representado especialmente pelos posseiros, que na MRG de Codó, apresentaram uma participação expressiva no ano de 2009, resultado este, que conforme foi apresentado anteriormente, pode ser estendido para a realidade maranhense, onde estes mesmos agentes sociais apresentam significativa importância tanto na quantidade de conflitos, como no número de famílias envolvidas.

Já os conflitos envolvendo quilombolas na MRG de Codó apresentaram no período uma importância relativa menor, em relação aos posseiros, embora muitas das famílias de posseiros fossem constituídas por remanescentes de quilombo. Este aspecto, trataremos logo em seguida. Já no que reporta ao contexto estadual, a maior parte dos conflitos e das famílias envolvidas estão circunscritos ao município de Alcântara, com 10 ocorrências, igual número apresentado por toda a MRG de Codó, com 151 famílias quilombolas envolvidas no total, o que equivale a $28,7 \%$ dos casos.

Agora para compararmos o número e a quantidade de famílias envolvidas em conflitos por terra, na MRG de Codó e no Estado do Maranhão, tomando como base o grupo dos posseiros e quilombolas, observe a Tabela 6 :

Tabela 6 - Microrregião geográfica de Codó/MA e Estado do Maranhão: Número de ocorrências e de famílias em relação ao número total de conflitos por categoria (2009).

\begin{tabular}{|c|c|c|}
\hline \multirow{2}{*}{ Agentes Sociais } & \multicolumn{2}{|c|}{ Microrregião geográfica de Codó/MA / Estado do Maranhão } \\
\cline { 2 - 3 } & Número de Ocorrências & Número de Famílias \\
\hline Posseiros & $29,4 \%$ & $46,2 \%$ \\
\hline Quilombolas & $10 \%$ & $9,8 \%$ \\
\hline
\end{tabular}

Fonte: CPT Conflitos no Campo Brasil 2009, p. 35 - 36. Org.: SILVA, A. E. R. (2012).

Percebe-se, por meio da Tabela 6, a importância relativa da participação de famílias de posseiros da microrregião geográfica de Codó no total das famílias de posseiros envolvidas em conflitos por terra no Estado do Maranhão em 2009, o que corresponde a 46,2\% do conjunto estadual. Destacamos na MRG de Codó, o caso da Fazenda Campestre Catulo, no município de Timbiras, que abrange 350 
famílias de posseiros em conflito pela terra, sendo no período considerado, o segundo conflito com maior número de famílias de posseiros na luta pela terra no Maranhão, sendo superada apenas pela Comunidade Piquizeiro, no município de Belágua, no nordeste do Estado, com 560 famílias de posseiros em conflitos por terra. Outrossim, o número de ocorrências de conflitos envolvendo posseiros na MRG é importante, se tomado em comparação com a luta empreendida por estes agentes sociais em todo o Estado, representando $29,4 \%$ do total.

Estes fatos corroboram as considerações de Oliveira (2011) referidas anteriormente acerca do crescimento da participação e da hegemonia das famílias de posseiros na luta pela terra no Brasil, e em particular na microrregião geográfica de Codó, onde o fenômeno é expressivo, em relação à realidade maranhense, com destaque para o caso de um conflito desenrolado em nossa área de estudo, o município de Timbiras.

Os conflitos deflagrados na fazenda Campestre do Catulo tiveram como marca principal a violência física, material e simbólica, representada pelas constantes ameaças, a destruição de casas de morada de famílias de posseiros e de suas roças, como revelou anteriormente Silva (2008)

Violência esta, que se reproduziu no ano seguinte por meio de novos conflitos por terra no município, e na microrregião de Codó, como podemos perceber por meio da Tabela 7. 
Tabela 7 - Microrregião geográfica de Codó/MA: Conflitos por Terra (2010).

\begin{tabular}{|c|c|c|c|}
\hline Município & Localização do conflito & Famílias & Tipo de conflito \\
\hline \multirow{4}{*}{$\begin{array}{l}\text { Alto Alegre do } \\
\text { Maranhão } \\
\text { (4) }\end{array}$} & $\begin{array}{l}\text { Fazenda Diamantina/ Com. } \\
\text { Faveira/ Água Branca }\end{array}$ & 65 & Quilombolas \\
\hline & $\begin{array}{l}\text { Com. Quilombola Marmorana / } \\
\text { Boa Hora } 3\end{array}$ & 22 & Quilombolas \\
\hline & $\begin{array}{l}\text { Gleba Campo do Bandeira / } \\
\text { Companhia Caxuxa Pastoril }\end{array}$ & 70 & Posseiros \\
\hline & Boa Hora 1 & 59 & Posseiros \\
\hline \multirow{14}{*}{$\begin{array}{l}\text { Codó } \\
(14)\end{array}$} & Cocal & 46 & Quilombolas \\
\hline & Comunidade Queimadas & 18 & Posseiros \\
\hline & Comunidade Três Irmãos & 20 & Posseiros \\
\hline & Estiva & 15 & Quilombolas \\
\hline & $\begin{array}{l}\text { Fazenda Salva Terra / Com. } \\
\text { Santa Rita dos Moisés }\end{array}$ & 42 & Quilombolas \\
\hline & Monta Barro & 10 & Posseiros \\
\hline & Paiol de Barro & 22 & Posseiros \\
\hline & Parnaso & 12 & Posseiros \\
\hline & Povoado Cacimba de Areia & 50 & Posseiros \\
\hline & Povoado Limão & 50 & Posseiros \\
\hline & Povoado São Domingos & 12 & Posseiros \\
\hline & Mata Virgem & 25 & Quilombolas \\
\hline & $\begin{array}{l}\text { Povoado Vergel/Vergel/Fazenda } \\
\text { Boa Esperança }\end{array}$ & 80 & Quilombolas \\
\hline & $\begin{array}{l}\text { Povoado Buriti Corrente / TG } \\
\text { Agroindústria }\end{array}$ & 140 & Quilombolas \\
\hline \multirow{2}{*}{$\begin{array}{l}\text { Coroatá } \\
\text { (2) }\end{array}$} & Santana & 43 & Posseiros \\
\hline & Fazenda Agrojaísa & 58 & Posseiros \\
\hline \multirow{2}{*}{$\begin{array}{c}\text { Timbiras } \\
(2)\end{array}$} & Comunidade Conceição & 42 & Posseiros \\
\hline & Fazenda Campestre Catulo & 350 & Posseiros \\
\hline MRG Codó & 22 & 1251 & \\
\hline MARANHÃO & 170 & 13.071 & \\
\hline
\end{tabular}

Fonte: CPT Conflitos no Campo Brasil 2010, p. 31 - 32. Org.: SILVA, A. E. R. (2012). 
A Tabela 7 revela que, com exceção de Coroatá, que manteve a mesma quantidade de conflitos por terra em 2010, o número de casos elevou-se de forma significativa, em relação ao ano anterior. O município com o maior número de ocorrências na microrregião geográfica referida foi Codó, que registrou 14 casos de conflitos por terra, o que corresponde $63,6 \%$ das ocorrências regionais no período. O município de Codó apresentou 6 casos de conflitos por terra no ano anterior e 14 em 2010.

O município de Timbiras também passou a contar com outro conflito representado pelas 42 famílias de posseiros da comunidade Conceição. A MRG de Codó apresentou um acréscimo de 183,3 \% no total de conflitos em relação ao período anterior. O mesmo vale para o número de famílias relacionadas a conflitos por terra, que avançou de 954 para 1251, isto é, um acréscimo de 131,1\%. Podemos estender a mesma análise para o Estado do Maranhão no que diz respeito ao número de conflitos (69, em 2009, e 170, em 2010 , elevação de 246,4\%)e de famílias envolvidas em conflitos por terra em 2010 (abarcou 5702 famílias em 2009, e 13.071 em 2010, crescimento de 229,2\% ).

No entanto, um fenômeno chama a atenção nos conflitos por terra na MRG de Codó, em particular no município de Codó. Quatro situações de conflitos por terra, representados pela Fazenda Salva Terra / Com. Santa Rita dos Moisés Mata Virgem, Povoado Vergel/Vergel/Fazenda Boa Esperança, Povoado Buriti Corrente / TG Agroindústria, que haviam sido designados como conflitos por terra relacionados a posseiros, foram designados no ano seguinte como conflitos por terra associados a quilombolas. Pensamos que a mudança na categoria tipológica de conflito por terra das referidas localidades se deve às facilidades de assegurar a delimitação de suas terras e a resolução dos conflitos pela posse da terra, por meio da designação como comunidades remanescentes de quilombo, de fato a origem de muitos desses casos classificados anteriormente como sendo posseiros. Esse fato também aponta para o aumento no número de conflitos por terra associados a comunidades quilombolas no município em particular, e na MRG de Codó neste último ano analisado. Observe os dados da Tabela 8. 
Tabela 8 - Microrregião geográfica de Codó/MA e Estado do Maranhão: Agentes sociais envolvidos nos conflitos de terra - Número de ocorrências e de famílias (2010).

\begin{tabular}{|c|c|c|c|c|c|}
\hline Agentes & Região & \multicolumn{2}{|c|}{ Número de Ocorrências } & \multicolumn{2}{c|}{ Número de Famílias } \\
\cline { 3 - 6 } Sociais & & Absoluto $\%$ do total de conflitos & Absoluto \% do total de conflitos \\
\hline Posseiros & MRG Codó & 14 & $63,6 \%$ & 816 & $65,2 \%$ \\
\cline { 2 - 6 } & Maranhão & 54 & $25,9 \%$ & 5.406 & $31,8 \%$ \\
\hline Quilombolas & MRG Codó & 8 & $36,4 \%$ & 435 & 34,8 \\
\cline { 2 - 6 } & Maranhão & 53 & $31,2 \%$ & 4.315 & $31,2 \%$ \\
\hline
\end{tabular}

Fonte: CPT Conflitos no Campo Brasil 2009, p. 29 - 32. Org.: SILVA, A. E. R. (2012).

Um incremento considerável em todas as variáveis pode ser notado, comparando-se as Tabelas 7 e 4, com exceção, no que reporta ao valor absoluto e relativo dos posseiros no número de ocorrências e das famílias envolvidas em conflitos por terra na MRG de Codó e no Estado do Maranhão. Ao contrário, apontamos mais uma vez, no que se refere aos quilombolas, que tiveram avanços na participação no número de conflitos e de famílias envolvidas na luta pela terra no contexto microrregional e estadual.

Para estabelecer uma analogia no interior do grupo, representado pelos agentes sociais aqui destacados, observe a Tabela 9.

Tabela 9 - Microrregião geográfica de Codó/MA e Estado do Maranhão: Número de ocorrências e de famílias em relação ao número total de conflitos por categoria no Estado (2010).

\begin{tabular}{|l|c|c|}
\hline \multirow{2}{*}{ Agentes Sociais } & \multicolumn{2}{|c|}{ Microrregião geográfica de Codó/MA / Estado do Maranhão } \\
\cline { 2 - 3 } & Número de Ocorrências & Número de Famílias \\
\hline Posseiros & $25,9 \%$ & $15,1 \%$ \\
\hline Quilombolas & $15,1 \%$ & $10,1 \%$ \\
\hline
\end{tabular}

Fonte: CPT Conflitos no Campo Brasil 2009, p. 29 - 32. Org.: SILVA, A. E. R. (2012).

A microrregião geográfica de Codó representou $25,9 \%$ do total de conflitos envolvendo posseiros no Estado do Maranhão, e 15,1\% do conjunto de famílias posseiras relacionadas a conflitos por terra em todo o Estado em 2010. Já no que se refere aos quilombolas a MRG apresentou $15,1 \%$ do total de ocorrências no 
Estado e $10,1 \%$ do volume de famílias quilombolas associadas a conflitos por terra na unidade da federação no período considerado. Se compararmos os dados da Tabela 7 com a Tabela 5, verifica-se uma redução dos posseiros em relação aos quilombolas, pelas razões expostas anteriormente.

Cabe enfatizar neste trabalho que as migrações originárias no Maranhão, e em particular na MRG de Codó, na qual situa o município de Timbiras - área selecionada em nossa pesquisa - marcado por diversos autores pela precariedade, vulnerabilidade e falta de oportunidades - tem no acesso igualmente precário, vulnerável e sem incentivos, no que se reporta a terra, condicionantes estruturais que nutrem este processo social.

As formas visíveis e invisíveis dessa violência manifestam-se na quantidade de conflitos, e no número de famílias envolvidas na luta pela terra, sobretudo de agentes sociais identificados por posseiros e quilombolas. As marcas dessa violência, contudo, não impingem nos corações e mentes desses homens, mulheres, enfim, de famílias inteiras, a falta de resistência, ou a aceitação social, e individual de uma violência doce. Essas múltiplas formas de resistência, ou melhor, formas cotidianas de resistência, de acordo com o uso conferido por SCOTT se territorializam de diferentes modos, seja nas regiões de origem, por meio da organização de uma associação de moradores das terras arrendadas para a CIT, no município de Timbiras, que culminou no Projeto de Assentamento CIT, iniciado pelo INCRA/MA, seja pela recusa moral, fundada em um ethos camponês, de submeter-se aos ditames dos senhores das terras, sejam eles pertencentes a elite política local, ou outros grupos econômicos extraregionais. Migrar também guarda este sentido, pois de acordo com Martins (2003, p. 43):

Se a migração temporária acentua a exploração do cortador de cana no canavial de São Paulo ou do peão numa derrubada de mata no Pará, criando uma nova miséria que empobrece o trabalhador como pessoa, ao submetê-lo a formas coercitivas e temporárias de trabalho, por outro lado, - liberta da coerção permanente, das relações de dependência pessoal com o fazendeiro vizinho ou com o proprietário da terra. Rompe a dominação pessoal, abre alternativas ainda que de pobreza alternativa. Abre, pois um caminho de emancipação da pessoa do trabalhador. 
A territorialização camponesa e a conformação de precárias territorialidades migratórias não se constituem processos sociais opostos e isolados. A criação da Associação de Moradores do Povoado Pedra Preta, no Projeto de Assentamento CIT/Novo Horizonte, possibilitou a organização das famílias para a conquista de melhores condições de vida, como a construção de moradias dignas, de alvenaria, e espaço para a comercialização dos produtos excedentes da roça, na Feira da Agricultura Familiar, que ocorre aos sábados, duas vezes por mês nas cidades de Timbiras e Codó.

Pesquisador: $\mathrm{E}$ as feiras em que o senhor leva os produtos daqui acontecem quando?

Seu Raimundo: Rapaz, tem umas aí que é de mês, quinze em quinze dias, essa feira do Agricultor, a feira do Agricultor, de quinze em quinze dias tem uma aí em Timbiras. Mas nós tem mesmo outra feira que é sábado, é terça e sábado, que é uma feira desde quando eu cheguei do Codó pra cá, que já funcionava essa feira, até junto com o Japão, que é o Japão, é do Codó, um verdureiro grande mesmo, que abastece, compra as coisa em Teresina e vende, ele compra na Ceasa e aí inventou essa feira, pra vender tomate, essas coisas, não sabe, verdura e aí a gente acompanha, acompanha essa feira desde essa época, vendendo verdura, quiabo, maxixe, abóba, é o pepino, essas coisa, enfim, negócio de verdura, não sabe? (Raimundo, 56, casado. Testemunho oral colhido no povoado Pedra Preta, Timbiras/MA, em 20/01/2011. Caderno de Entrevistas, p. 189).

Mesmo não possuindo banca na feira semanal em Timbiras, a venda do excedente é uma possibilidade para a aquisição de outras mercadorias, para muitos agricultores, como no caso de seu Raimundo. Veja a feira semanal, realizada toda terça, na Figura 11: 


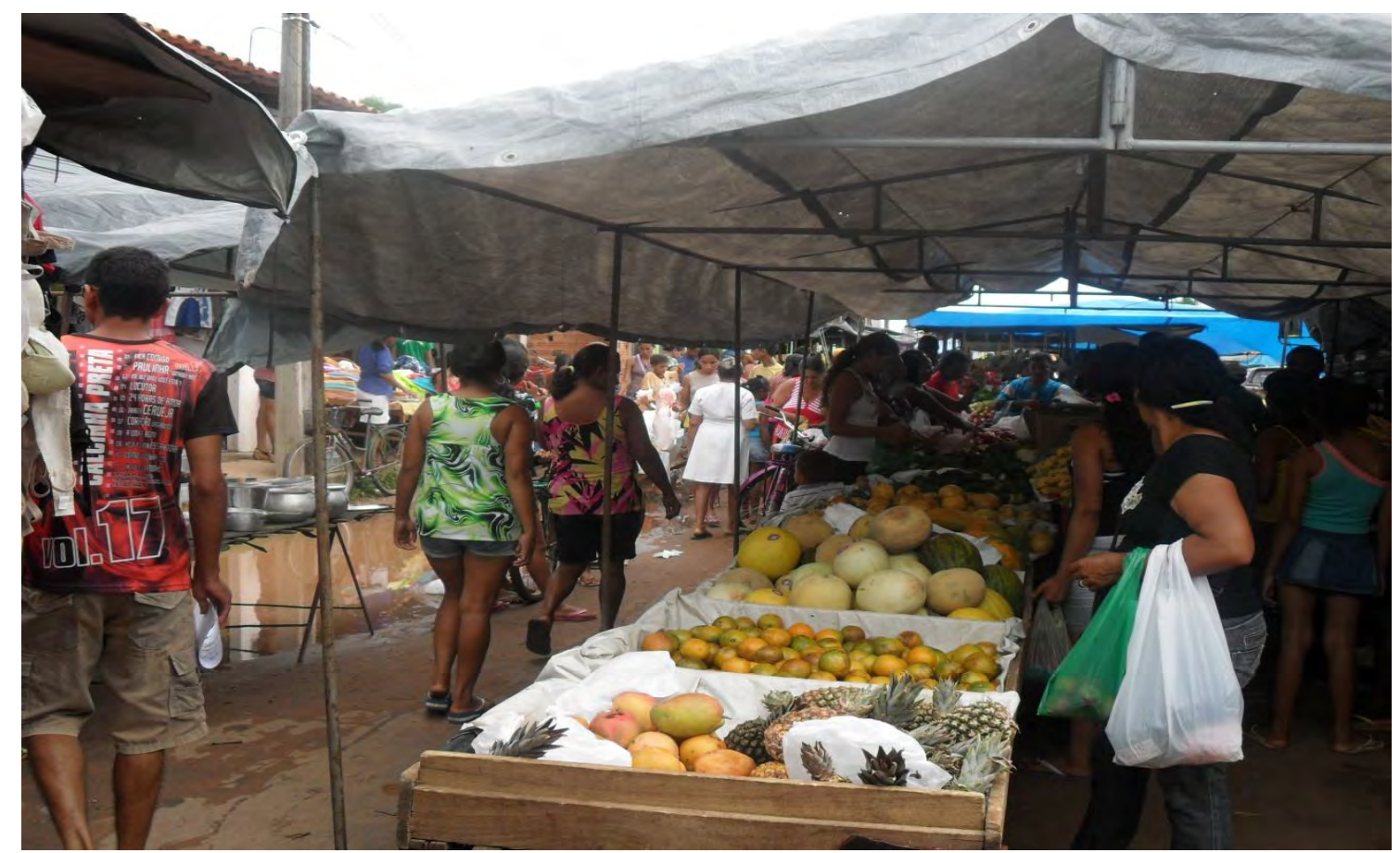

Figura 11- Feira livre. Venda de produtos na feira de terça na cidade de Timbiras/MA.

Foto do autor, 18 de Janeiro de 2011.

Além dos cultivos da roça é momento também para a compra e venda dos derivados do babaçu como carvão e o azeite. Vender significa sacrificar parte dos cultivos alimentares voltadas ao consumo familiar para aquisição de outros produtos, conforme indicam as falas de Francisca e José:

Pesquisador: E o que a senhora planta: a maior parte é para o consumo da família ou a senhora vende uma outra parte da produção?

Francisca: Oh, nós vendia muito, assim, não é, porque nós não tínhamos ainda esse Bolsa-Família, não é? E aí depois que a gente fez esse Bolsa Família, aí já melhorou. Melhorou um pouquinho, não é? Porque nós vendia muito legume, para comprar assim, as coisas para casa, até roupa, mesmo, para nós, não é? Mas depois que nós fizemos o Bolsa Família, aí melhorou cem por cento, não é? A gente já vendeu, mais poupa, as vezes em vende chega a vender né, fica mesmo só com o consumo de casa mesmo. . (Francisca, 42. Testemunho oral colhido em 16/01/2011, na cidade de Timbiras/MA. Caderno de Entrevistas. P. 77 - 78).

Não, sempre tudo o que ele consegue é só pra assumir a família, ele não vende não. Tem algumas pessoas que pega a colheita da roça, o arroz, milho, vende, e depois fica 
comprando aos poucos pra comer, que eu vejo muitas pessoas fazer isso. Meu pai não faz isso não. Sempre consegue para casa.

(José, 26, solteiro. Testemunho oral colhido em 21/01/2011, na cidade de Timbiras/MA. Caderno de Entrevistas, p. 286)

As falas registradas pelos testemunhos orais apontam a importância dos cultivos da roça para suprir as necessidades de consumo da unidade familiar. A venda na feira representa um momento complementar da economia doméstica, com a intenção para adquirir dinheiro para comprar mercadorias não produzidas na terra. O testemunho de Francisca ainda revela a importância de programas federais de transferência de renda, como o Bolsa-Família, não só para garantir a educação dos filhos, sonho almejado por muitas famílias camponesas, mas também para evitar a comercialização dos parcos e limitados excedentes da produção familiar. Debruçaremo-nos sobre os programas de transferência de renda, como o Bolsa Família, no tópico a seguir.

O dia da feira também significa a oportunidade dos moradores dos povoados do interior do município ir para a cidade, comprar alimentos e outras mercadorias na cidade. $\mathrm{O}$ transporte até o núcleo urbano, sobretudo daqueles que vivem em regiões distantes da cidade, ocorre principalmente por caminhões de "paus de arara", mais uma vez, demonstrando a forma precária de locomoção, sobretudo dos mais pobres. Veja a Figura 12: 


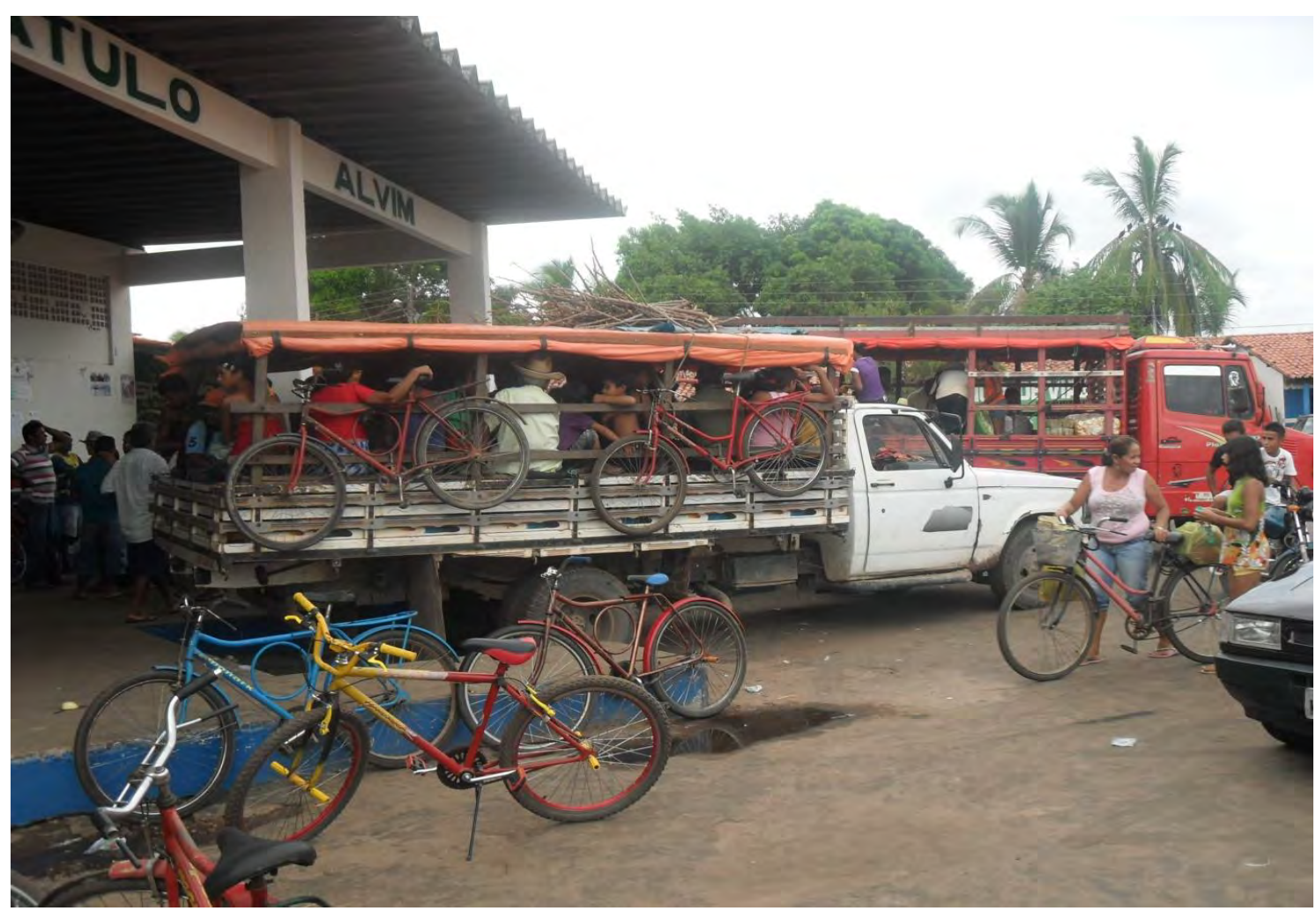

Figura 12 - De volta para o "interior". Retorno de moradores aos povoados do interior do município de Timbiras após o término da feira livre de terça na cidade. Foto do autor, 18 de Janeiro de 2011.

O transporte precário, conhecido popularmente como "pau-de-arara" permite o elo entre as dezenas de povoados do município com o núcleo urbano. $\mathrm{Na}$ Figura 12, observa-se a saída de "paus-de-arara" do terminal rodoviário municipal.

No entanto, muitos jovens partem sozinhos ou com a família para o trabalho em outras regiões, vindos de diferentes experiências sociais: de famílias que foram expropriadas e expulsas de suas unidades camponesas por latifundiários, que não possuem terra, que se submetem a prática do arrendamento, morando junto da roça, ou na "ponta de rua", ainda aqueles que não apresentam vínculo com as lides agrícolas, e se dedicam a bicos ou serviços domésticos, assim como aqueles que a família possui pouca terra, e se enquadram na condição de posseiros, pequenos proprietários e assentados. Em todas estas modalidades que podemos utilizar para classificar estes agentes sociais, a migração, sobretudo dos mais jovens se faz presente. Essa é a nossa preocupação no tópico que se segue. 


\subsection{A Migração "Temporária" para os Canaviais Paulistas}

A ausência de trabalhadores e famílias residentes em Timbiras durante a safra canavieira no Centro-Sul transformam as práticas cotidianas no município. $\mathrm{O}$ vai $\mathrm{e}$ vem constante dos ônibus que transportam pessoas e famílias de um lado para outro, a construção de uma territorialidade maranhense nas cidades paulistas, e a incorporação de hábitos alimentares e elementos construtivos, são materializações do que Silva (2008e) designa como cultura migratória.

A migração de trabalhadores e famílias do município de Timbiras, para o trabalho na cultura canavieira, a partir da residência na cidade de Pradópolis e Guariba, não pode ser compreendida a partir de um enfoque macroestrutural, que vislumbra apenas os elementos objetivos, sobretudo de natureza econômica, orquestrados pelas demandas do capital. Os determinantes estruturais existem, mas não podem ser tomados como exclusivos na compreensão do processo migratório.

Não podemos ler os deslocamentos desses agentes sociais a partir das lentes de um recorte teórico que compreende a migração como uma estratégia de sobrevivência da unidade camponesa nos seus lugares de origem, sabendo que parcela importante dos trabalhadores que residem nos bairros de "ponta de rua" da periferia de Timbiras, constituem a primeira ou a segunda geração de camponeses expropriados, que romperam seus vínculos diretos com o trabalho na terra e se se deslocam em busca de emprego para manter minimamente a reprodução da unidade familiar e não mais a camponesa, de acordo com PONTES (2011).

Para clarear essas fontes interpretativas que circunscreveram os estudos migratórios, sobretudo no âmbito da Sociologia, no século XX, Silva e Menezes (2007) apresentam um balanço dos principais autores e pesquisas.

A primeira corrente de estudos elencada pelas autoras foi designada como macroestrutural e explicava as migrações internas, a partir da força da estrutura social e do modo de produção capitalista no país, produzindo desigualdades regionais. Compõe essa linha teórica os trabalhos de Lopes (1971), Singer (1978), Durhan (1978) e Oliveira (1977). 
De acordo com Silva \& Menezes (2007, p. 2), o estudo de Juarez Brandão Lopes, intitulado "A Sociedade Industrial no Brasil", publicado em 1971 compreendia as migrações como sendo a transferência de população de regiões arcaicas para as modernas, processo gestado no interior do modo de produção capitalista, que tinham como carro-chefe no país as metrópoles industriais da região Sudeste. O economista Paul Israel Singer, em seu texto clássico "Migrações Internas: Considerações Teóricas" publicado no livro "Economia Política da Urbanização" dá relevo a produção das desigualdades regionais brasileiras tendo como fundamento as migrações massivas para as regiões de concentração industrial, a partir de dois elementos estruturantes: os fatores de mudança e os fatores de estagnação. O primeiro atua, impulsionando movimentos demográficos em virtude da incorporação de melhorias técnicas na agricultura e da territorialização do capital. Já o segundo produz deslocamentos de integrantes da família camponesa, devido às limitações fundiárias e produtivas da pequena unidade familiar, gerando força de trabalho disponível para o assalariamento e o trabalho sazonal nas grandes culturas comerciais do Brasil. Eunice Durham, em "A Caminho da Cidade" (1978) prioriza o desenvolvimento diferencial das regiões como a justificativa para a ocorrência das migrações campo-cidade no interior do país.

"A Crítica da Razão Dualista", de Francisco de Oliveira explica a existência de regiões mais e menos desenvolvidas no Brasil em função do processo de acumulação do capital. Contudo, avança em relação aos pesquisadores supracitados por evidenciar neste trabalho o significado da migração para os agentes envolvidos neste deslocamento.

Um segundo movimento de pesquisas debruçou-se sobre a problemática das migrações internas no Brasil, sobretudo as de natureza rural-urbana, a partir da sua concepção como uma estratégia de reprodução social camponesa.

Os pesquisadores, alinhados a esta recorte interpretativo atentaram suas investigações nas múltiplas dimensões do camponês, sobretudo na sua condição de trabalhador migrante, como alternativa de viabilizar a reprodução da unidade familiar, enquanto camponeses na região de origem. Daí destacarmos Garcia Jr. (1983, 1990), Heredia (1979), Menezes (1985, 2002), Woortmann (1990), Suarez (1977), entre outros, preocupados, sobretudo em compreender a expressão do 
capitalismo na agricultura e organização social camponesa, particularmente para o mundo do trabalho, sobretudo na área marginal da plantation canavieira nordestina. Tais referências se mostram importantes por explicitar o papel que os camponeses têm no local analisado, qual é a sua origem, trajetórias e se possível comparar o significado deste movimento migratório com outros períodos de recepção deste grupo de trabalhadores rurais.

Por fim, um terceiro conjunto de pesquisas reúne estudiosos que fazem uma análise da migração e dos migrantes a partir de múltiplas determinações. Busca-se compreender os roteiros dos agentes sociais a partir das determinações estruturais, objetivas, que possibilitam este processo social, assim como as suas representações sociais e simbólicas. Aqui situam os trabalhos de José de Souza Martins (1986), Maria Aparecida de Moraes Silva (1999) e Marilda Aparecida de Menezes (1985,2002), dentre outros.

A primeira linha de interpretação reduzia a migração reduzida a fluxo, volume, interligando de forma estática as "áreas de atração" às de "repulsão", as "atrasadas" às "modernas" e as de "origem" às "destino", conduzida pelos ventos do capital. Este grupo de estudos não captam os elementos subjetivos, indizíveis, simbólicos e nem permitem uma relação de intercâmbio entre a migração e o agente migratório.

Dentro do nosso universo de investigação, não podemos abreviar a compreensão da migração de trabalhadores rurais de Timbiras para o trabalho no corte de cana em São Paulo, a partir da força sobrenatural exercida pelos representantes do agronegócio canavieiro paulista. Temos que considerar também outros elementos estruturantes que marcam decisivamente estes deslocamentos como a acentuada concentração fundiária no município de Timbiras e na microrregião de Codó, assim como as precárias e incertas oportunidades de emprego geradas pela economia urbana.

Elementos subjetivos também impulsionam o processo migratório, motivado por desavenças familiares, desejo de rompimento das relações de mandonismo e dependência pessoal perante os latifundiários, ilusões que fomentam os anseios de aventura e "viagem" por regiões distantes em busca de melhores oportunidades de vida. 
A partir do exposto, compartilhamos as concepções de Silva acerca da migração e dos migrantes, como um acontecimento histórico, um processo social que atinge tanto os que partem quanto os que ficam, reunindo elementos objetivos e subjetivos. É dentro desta linha interpretativa que buscamos compreender a conformação de territorialidades precárias no município do Maranhão e nas cidades paulistas, e que tem continuidade e significado para a vida de famílias e pessoas. Um histórico processo de pobreza que impõe a migração sazonal como regra para toda uma vida.

A migração sazonal sucessiva e repetida ao longo de determinado período de vida, para diferentes destinos, é questionada por Silva (1997), que pretende a partir do conceito de permanência das migrações temporárias, compreender os múltiplos significados que este processo social implica na organização da vida familiar. Processo que não provoca de modo duro, uma ruptura sem volta, mas reproduz no plano simbólico um retorno material, embora experimentado e aproximado nos destinos, a partir das territorialidades migratórias, unindo no plano das representações o cá e o lá distantes geograficamente.

O período e a intensidade da migração para o trabalho nos canaviais de São Paulo tem duração e efeitos distintos para as pessoas e famílias. Segundo os testemunhos orais:

Pesquisador: Você pretende ir embora?

Eu quero ficar mais um ano, e quero ir embora. O trabalho é pesado, já fiz cinco safras. Acho que os rapazes novos já vieram tudo, quem não veio são os mais velhos. Duas noites e dois dias são o tempo da viagem. Não chega a três dias. A gente quer comprar a casa e se sobrar, a moto. (Valdenir, 25, casado. Testemunho oral colhido em 23/10/2010, em Guariba/SP. Caderno de Entrevistas, p. 13)

Percebe-se que o jovem timbirense prioriza a compra da casa na cidade, projeto futuro da família instalar-se na sede do município maranhense. Testemunhos de outra família mostram que migração para o trabalho na cana nutria conquistas econômicas que se distinguiam pelo estado civil dos irmãos. 
Pesquisador: (...) Você pensou em ficar definitivamente lá? Qual que foi a maior intenção sua ao ir cortar cana lá em São Paulo?

Francisco: A minha intenção mesmo é fazer uma casa. Construir uma casa na rua e trabalhar, não é?

Pesquisador: E para você Joésio?

Joécio: Eu sou solteiro, eu vou comprar uma moto, um terreno também.

Silva (2008) e Carneiro et al. (2007) apresentam os benefícios materiais advindos dos recursos economizados a duras penas à partir do trabalho extenuante na lavoura de cana. A concretização da aquisição desses objetos de consumo, que atingem os integrantes da família, e também os jovens que nutrem planos para "viajar" no futuro, é representada por meio dos trechos de registros orais abaixo:

Pesquisador: E aí no caso, o que vocês conquistaram lá financeiramente com o corte da cana, deu para melhorar a vida da família aqui?

Domingos: Dá para segurar uns dois meses sossegado. Para segurar mesmo, não dá não. Não dá para segurar. $E$ volta lá de novo, trabalhar um pouquinho, ajeitando devagarzinho, trazer mais um pouquinho, não é? (Domingos, 21, solteiro. Testemunho oral colhido em Timbiras/MA, em 19/01/2011. Caderno de Entrevistas, p. 135).

Os dois meses, referidos por Domingos, relacionam-se ao período em que o trabalhador foi contemplado pelo seguro-desemprego, recurso necessário para manter as despesas do entrevistado durante a entressafra da cana, mas que não é suficiente para segurar, tendo que deslocar-se mais uma vez para trazer mais um pouquinho, para poder prover minimamente as suas necessidades pessoais e também da família. Em outros casos, as conquistas materiais obtidas a partir do trabalho na cana só tem significado a partir do estabelecimento da esposa e dos filhos na cidade do interior paulista, conforme podemos notar no testemunho na página 93: 
Pesquisador: Quatro anos. E aí compensou?

Randerson: Compensou. Já deu pra juntar uma porção de coisa, ajuda bastante, não é? $\mathrm{E}$ também tendo com a minha família aqui perto de mim, o que mais importa pra mim é isto. Eles estando comigo, pra mim, é uma grande ajuda com eles. Eu ter eles na minha vida pra mim nada é impossível pra mim. Eu posso ter a coragem e força e a gente vai pra frente. (Randerson, 22, casado. Testemunho oral colhido em 22/07/2011, em Guariba/SP. Caderno de Entrevistas, p.300 301)

A presença da família na cidade do interior paulista sustenta a persistência e dá coragem e força para o trabalhador diante do sofrimento diário enfrentado nas lides dos canaviais, em busca de dias melhores. Também possibilita a opção de contar em casa com a mulher que realiza os serviços domésticos enquanto os que migraram sozinhos terão que depois do trabalho penoso no campo, executar as tarefas da residência.

O sofrimento decorrente da migração também se intensificou entre os dias 23 e 24 abril e 2 e 3 de maio de 2009, quando fortes chuvas provocariam uma elevação acentuada dos níveis d' água do rio Itapecuru e principais afluentes. $\mathrm{Na}$ área urbana, ruas do bairro São Sebastião, Centro, Olaria, Forquilha, Horta, Mutirão, São Raimundo, Santarém e Anjo da Guarda foram afetadas.

Os povoados de Campestre dos Alvins, Abundância, Flores, Sapucaia, Beija-Flor, Santo Antônio, Laguinho, Cachoeira, Vidal, Jaibara, Sete, Juçara, Mamorana, Marajá, Jacaré, Lagoa do São José, São José, Lagoa Preta, São Benedito, Matinha, Alegria, Axixá, Boa Hora, Boa Fé, Lagoa Grande, Fazenda Pipoca, Mil Braças, Santa Cruz, Pedra Preta, Curimatá, Bebedouro, Melancias, Morro Branco, Santaninha, São Benedito I, São Benedito II, Capoeira, Gameleira, Bom Jardim, Bacabeira, Baixão do Leite, São Domingos, Lagoa do Tufi e Mata Fome, conforme documento publicado pelo escritório regional do Sistema Nacional de Defesa Civil - SINDEC em 2009 (Pesquisa de campo, Janeiro de 2011). Observe a Figura 13 e a Figura 14. 


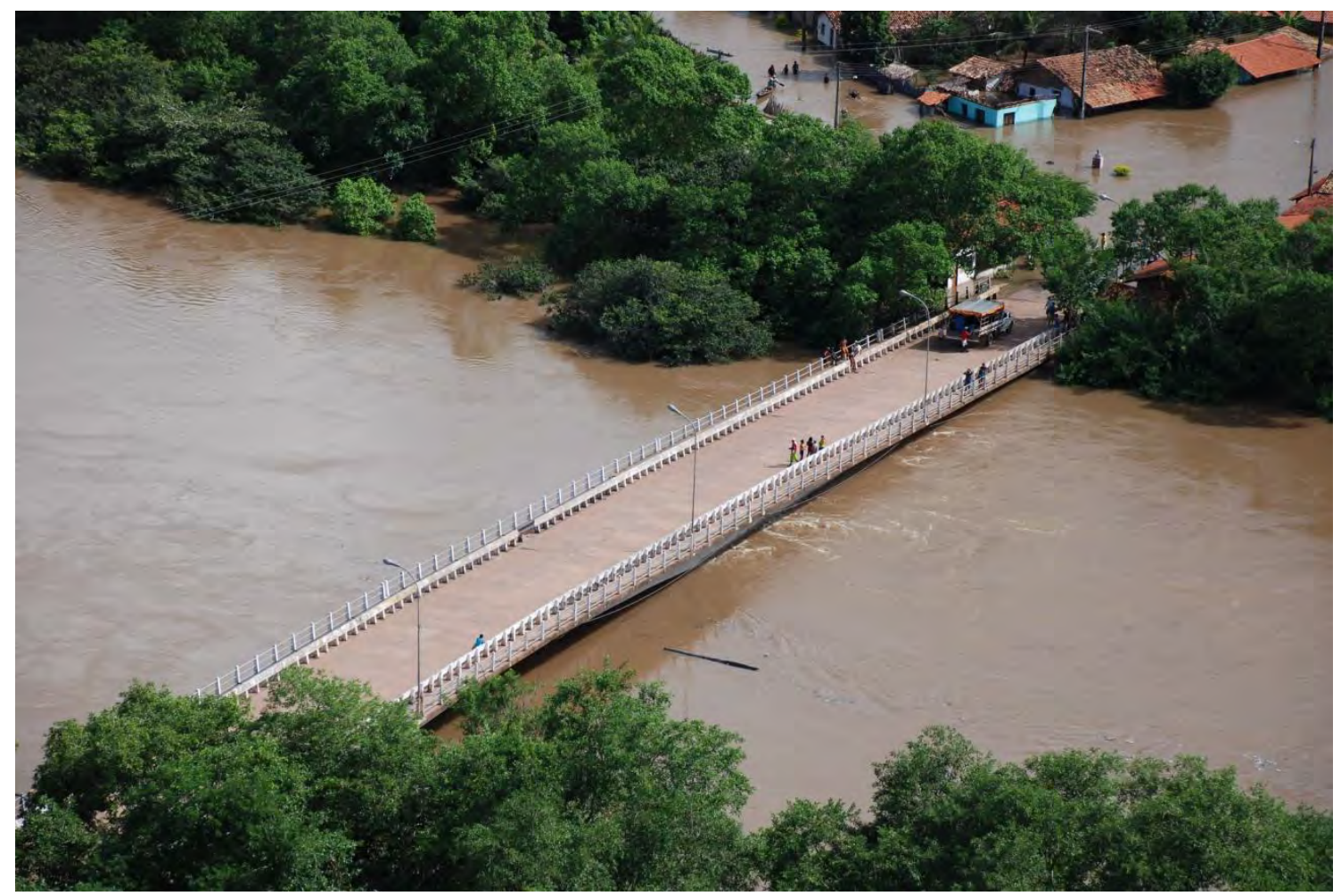

Figura 13 - Vale alagado. Vista sobre a ponte José Sarney, que liga o bairro de Olaria, à esquerda da foto, ao bairro de São Sebastião, encontrado a esquerda da imagem na cidade de Timbiras/MA.

Foto cedida pelo SINDEC. Pesquisa de campo em 18 de Janeiro de 2011.

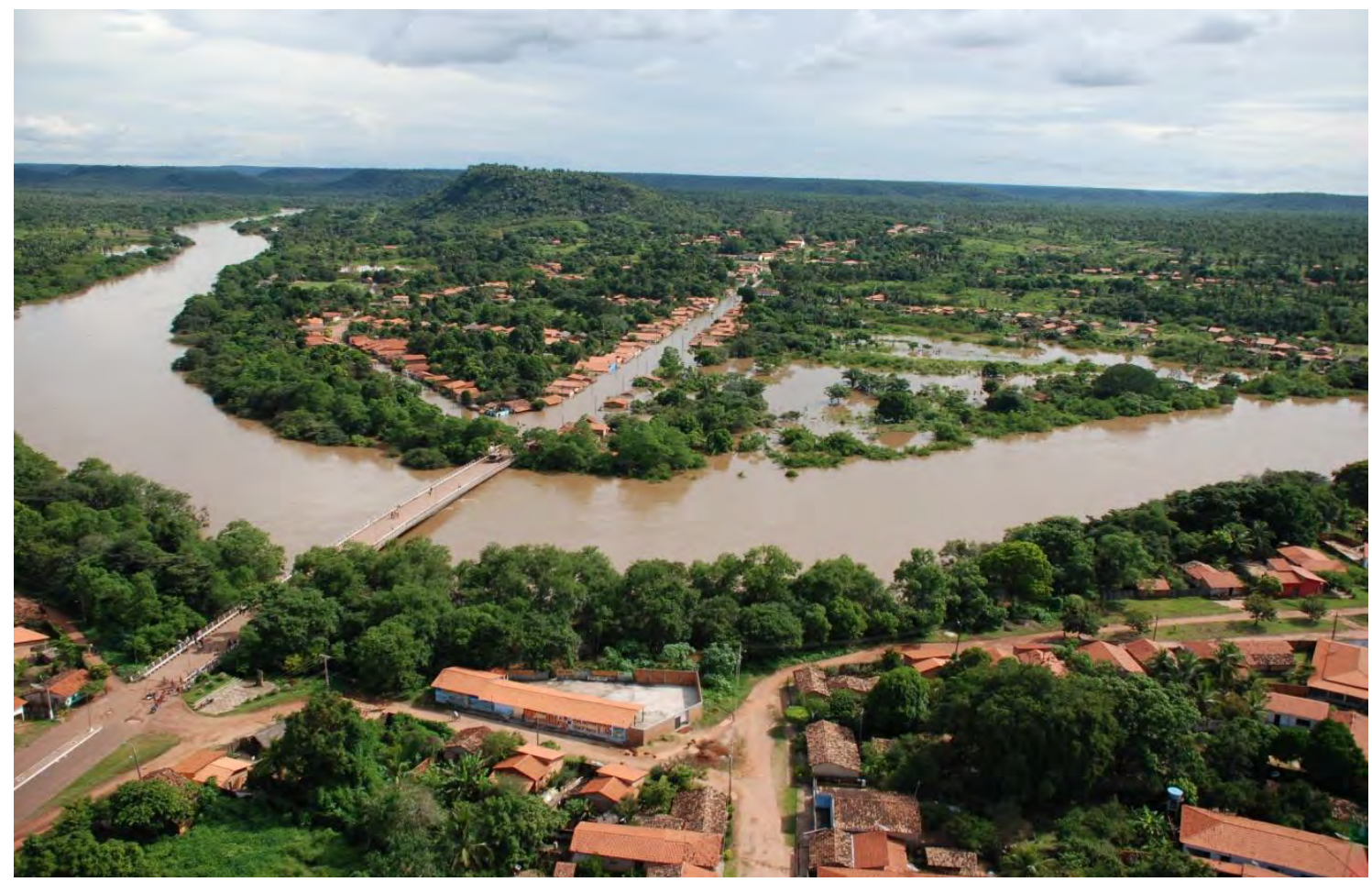

Figura 14 - Vista do Bairro São Sebastião. Na margem esquerda do rio. O bairro São Sebastião, encontrado na margem côncava de um meandro do rio Itapecuru teve extensas áreas atingidas pela cheia do curso fluvial em abril/maio de 2009. Foto cedida pelo SINDEC. Pesquisa de campo em 18 de Janeiro de 2011. 
As famílias desabrigadas foram abrigadas em igrejas e centros comunitários, como a Associação de Moradores do Bairro São Sebastião, situada em uma porção mais elevada do bairro São Sebastião, fortemente atingido pela cheia. Veja a Figura 15:

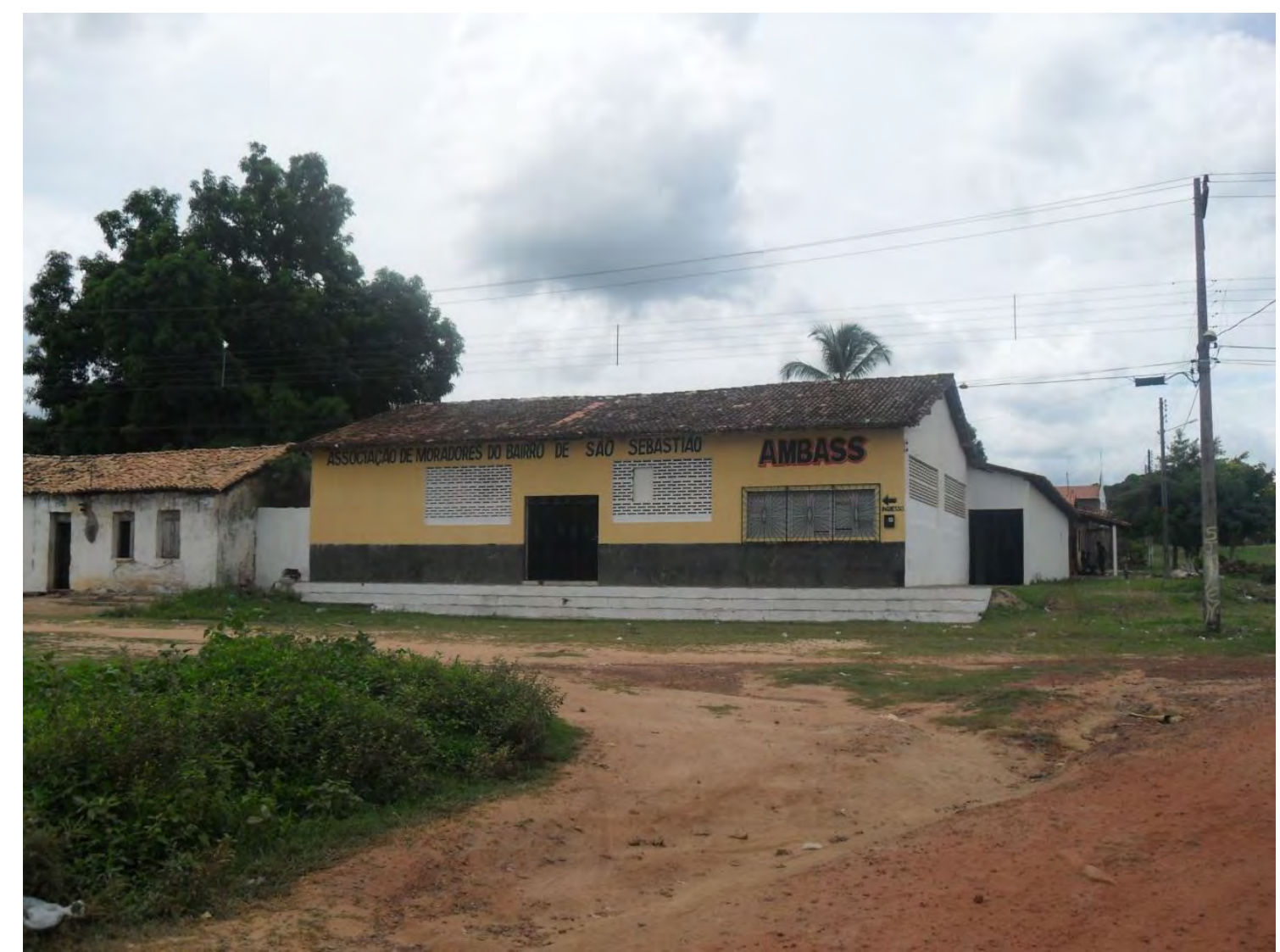

Figura 15 - Comunidade. Fachada do prédio da Associação de Moradores do Bairro São Sebastião, no núcleo urbano de Timbiras/MA.

Foto do autor, 20 de Janeiro de 2011.

As perdas materiais decorrentes da inundação acentuaram a migração de Timbiras, de acordo com o registro oral de Domingos: "E depois da enchente ônibus não teve paradeiro na rodoviária não! Era cheio de gente saindo para lá. Até medo!" (Domingos, 60, casado. Testemunho oral colhido em Timbiras/MA, em 19/01/2011. Caderno de Entrevistas, p. 137).

O agravante natural somava à falta de emprego e condições que permitissem o trabalho da família na unidade camponesa. Planos foram refeitos por migrantes e suas famílias, conforme o testemunho de um trabalhador maranhense registrado em Serviço Pastoral do Migrante $(2009$, p. 57,58$)$ em maio de 2009: "Também fiquei sabendo que as enchentes atingiram minha roça". 
O que ganhei só deu para pagar a conta do mercado de $\mathrm{R} \$ 280,00$. Estou voltando pra minha casa com ajuda dos outros".

Os projetos de consumo variam de acordo com a idade e o estado civil dos trabalhadores rurais migrantes. Veja o testemunho abaixo:

Pesquisador: $E$ aí no caso, o que a família da senhora conseguiu depois que o Jonas foi para São Paulo? Em termos materiais?

Francisca: Ah, depois que ele foi para São Paulo, aí melhorou, porque nem eu disse ainda agora, não é, melhorou porque nós não tinha, não é, nós não tinha o que nós tem hoje, não é. Nós tem nossa televisão, nós tem nossa geladeira, nós tem nosso fogão. Nada disso eu tinha, você acredita? Tinha não. $\mathrm{E}$ aí agora a gente tem. (Francisca, 42, casada. Testemunho oral colhido em Timbiras, em 16/01/2011. Caderno de Entrevistas, p. 80).

Os objetos de consumo adquiridos para a casa mostram a preocupação, e também a necessidade de utensílios indispensáveis a vida na cidade, como o fogão, que em muitos lares, conciliou ou substituiu o caro fogão à gás, apontado em um testemunho apresentado neste capítulo.

Os objetos materiais que perduram, produto das experiências migratórias de integrantes da família ficam e acompanham os deslocamentos migratórios como ressalta Mello (2007). Outras conquistas ficam no município maranhense, e esse desejo de permanecer nunca sai do horizonte esfumaçado carregado de incertezas e infortúnios que violentam a vida desses migrantes pobres. O desejo da permanência é reverenciado no testemunho oral de Antônio:

Porque o sonho de todo o mundo é morar em sua cidade, não é? Crescer, morar, em sua cidade, e não ficar se destacando daqui para outro Estado para ir em busca de novas melhoras de vida, não é, para estar se submetendo a certos trabalhos para tentar trazer um pouco para a sua cidade, para manter a sua família, ter uma melhor casa. (Antônio, 24, solteiro. Testemunho oral colhido em Timbiras/MA, em 18/01/2011. Caderno de Entrevistas, p. 125). 
A fala de Antônio destaca o sonho de morar na cidade natal, e entendemos que pode ser estendida aqueles que foram expropriados de suas roças no campo, manifestando o sentido compulsório dessa migração, como apontou Silva (2005). A presença dos familiares e amigos, das lembranças compartilhadas, das particularidades do ambiente físico, reforçam a importância do lugar para os trabalhadores migrantes: "Lá é mil vezes melhor que aqui, sente uma alegria no peito". (José, 26, solteiro. Testemunho oral colhido em Guariba/SP, em 24/10/2010. Caderno de Entrevistas, p. 52).

A ausência de tantos trabalhadores e famílias trouxeram elementos novos adquiridos nos territórios de circulação migratória, e ressignificaram outros, como o dia dos pais, os filhos criados pela avó, as festas na cidade. No que reporta a este último aspecto Domingos pronuncia:

Assim, pelo período que eu fiquei lá, na cultura, aqui em Timbiras, ficou, digamos assim um buraco, não é, na cultura aqui em Timbiras, não é, digamos assim, porque muitos participavam de quadrilha, de boi, não é, e teve uma redução, não é, do número de pessoal que participava dessas brincadeiras no mês de junho, das festas. Até o pessoal ia participar agora, não é, e tinha pouca gente, não é, para poder participar, principalmente os homens que dançam mais, não é? Aí ficou tipo um buraco assim, o pessoal: ó fulano de tal que dançava não tá mais, aí perdeu a graça, não sei o quê porque teve que ir para lá, para trabalhar, cortar cana. Então, tem essas coisas. $E$ na questão do lado social assim a gente vê a questão do lado das pessoas que ficam aqui e as vezes perdem até a comunicação com quem tá lá, não é? Fica sem se comunicar muito tempo, e as pessoas ficam preocupadas, não é, principalmente os jovens, não é, que ainda na questão da juventude quando vão para lá, que as vezes passa por esquecido quem tá aqui, não é? As vezes não quer se lembrar mais, não quer conversar nem com os pai, nem com a mãe. Tem essas coisas. Acontece também de muitos que muitos que vão daqui e quando chegam lá se envolvem com tráfico de drogas. E está presente bastante as drogas nos canaviais lá, não é? Se envolvem lá e já ficam. (Antônio, 24, solteiro. Testemunho oral colhido em Timbiras, em 18/01/2011. Caderno de entrevistas, p. 119).

No entanto, apesar dos diferentes significados que guardam a moradia e o morar, a reforma da casa, objetivo de muitos trabalhadores migrantes nos 
canaviais de São Paulo, se materializa, a partir de elementos construtivos conseguidos a partir do trabalho nos canaviais paulistas. Veja a Figura 16 e a Figura 17:

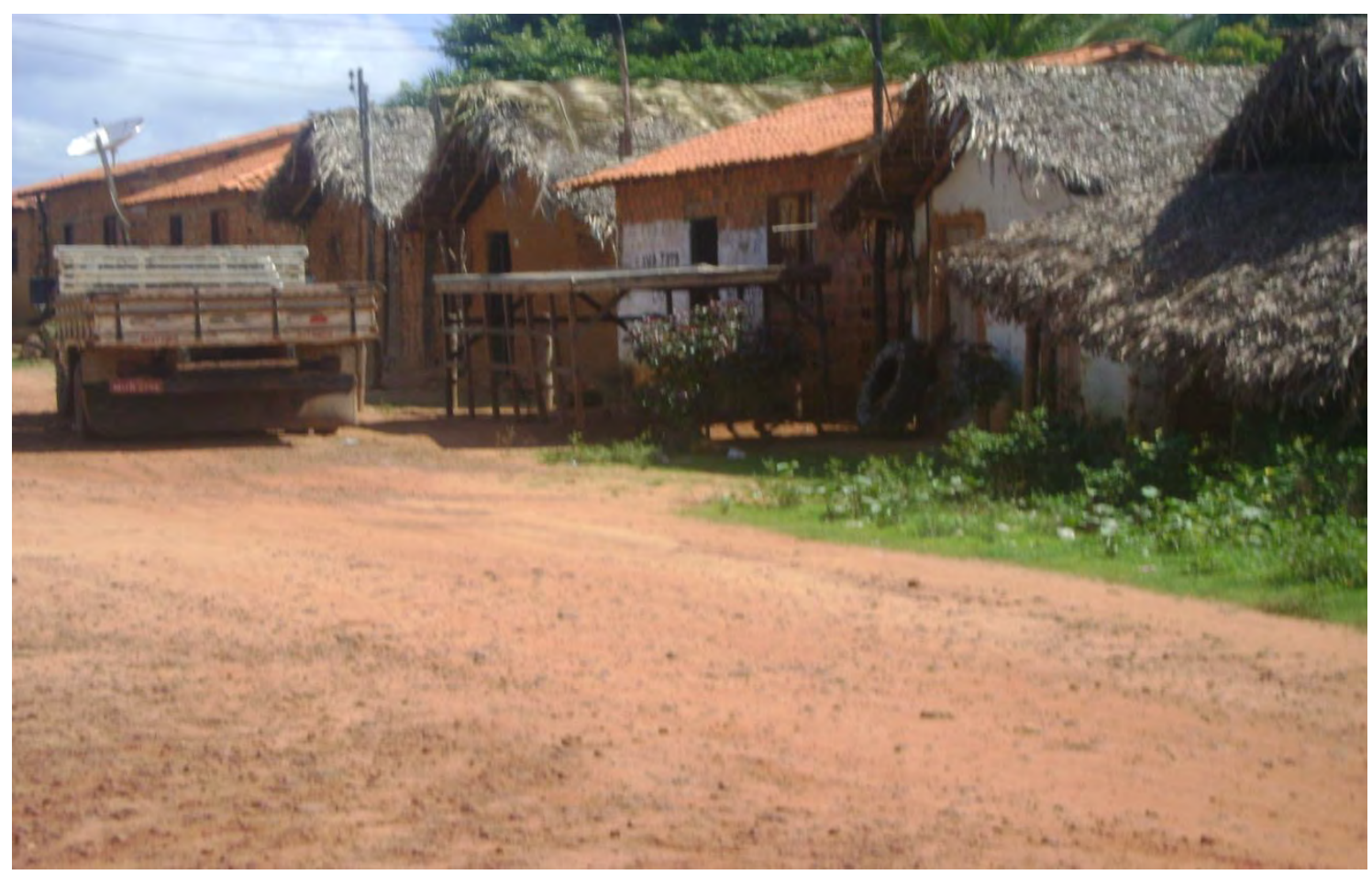

Figura 16 - Mudança nos padrões construtivos das casas do núcleo urbano de Timbiras/MA.

Foto do autor, 11 de Janeiro de 2010.

$\mathrm{Na}$ Figura 16, nota-se o contraste entre casas com parede de taipa e moradias de alvenaria com telhado. O padrão construtivo das moradias que predominava na sede municipal era a da casa erguida com paredes de taipa, coberta por folhas de babaçu. Com o ingresso de muitos trabalhadores no corte da cana, muitas moradias mais confortáveis e dignas foram reformadas ou refeitas de alvenaria com telhado. 


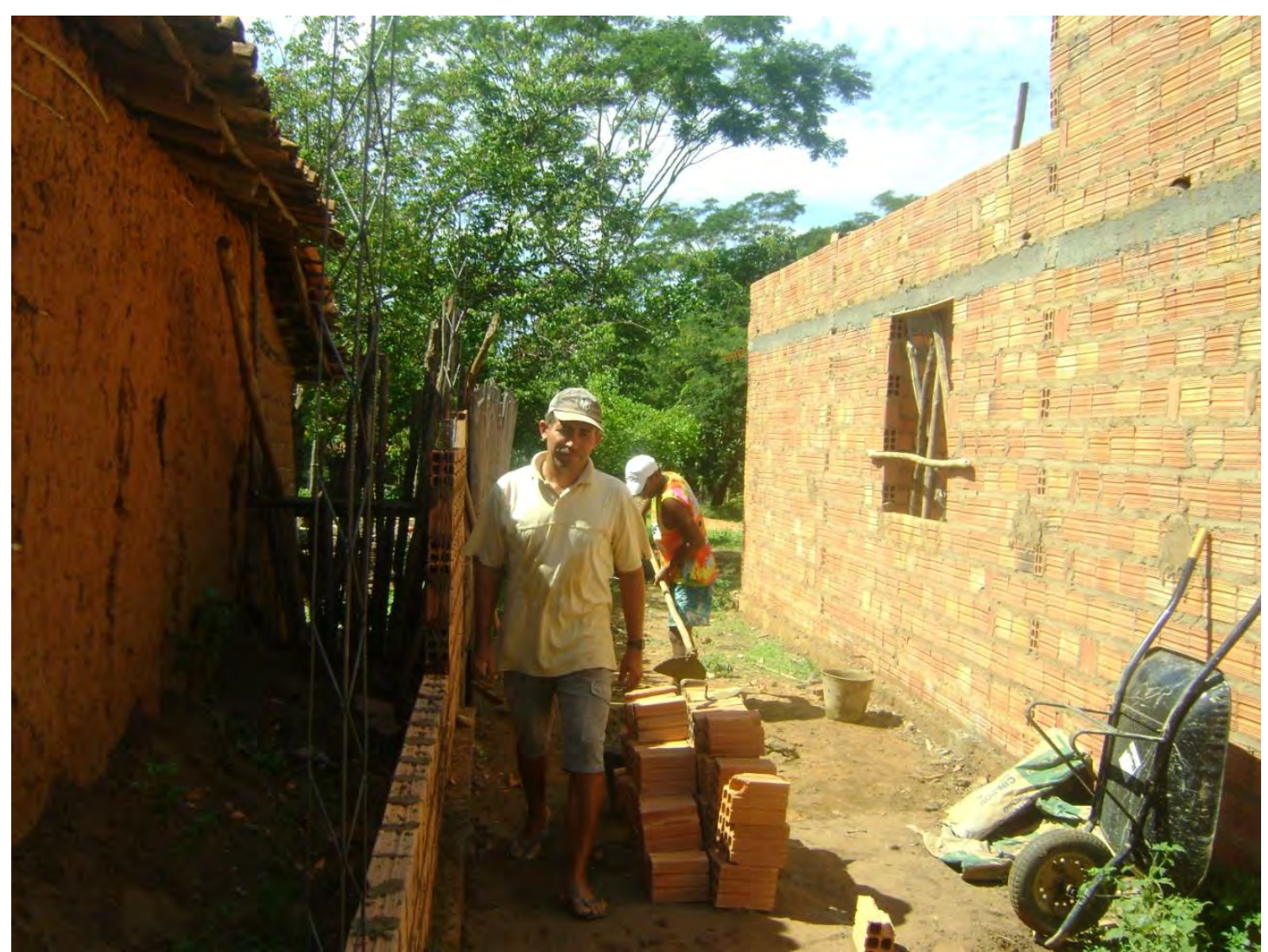

Figura 17 - Contraste. Construção de casa de alvenaria ao lado de uma moradia com paredes de adobe na cidade de Timbiras/MA.

Foto do autor, 11 de Janeiro de 2010.

Não só do ponto de vista material, a vida social na cidade se reconfigura com as migrações. Se as festas dos santos juninos e de São Raimundo Nonato, sentem a ausência dos homens e famílias que partiram, no Natal e no dia de São Sebastião, a reunião de familiares e amigos traz novos significados para as celebrações religiosas.

Durante os festejos do santo padroeiro, feriado municipal, realizam-se batizados de filhos nascidos longe do pai, durante a safra da cana,e de filhos nascidos longe dos demais parentes e amigos, nas cidades canavieiras do interior paulista

$\mathrm{Na}$ cerimônia religiosa do Natal e no dia de São Sebastião, feriado municipal, concentram-se os batizados dos recém- nascidos, crianças que nasceram na permanente migração temporária de seus familiares.Muitos nasceram no município maranhense; outros nas cidades que residem seus pais nos territórios de destino migratório. Aqueles que partem para Timbiras durante a 
entressafra aproveitam a breve permanência na cidade para introduzir o filho nos ritos cristãos, e renovar os laços de reciprocidade com parentes, amigos e familiares. Veja a igreja de São Sebastião, situada no bairro homônimo, na Figura 18:

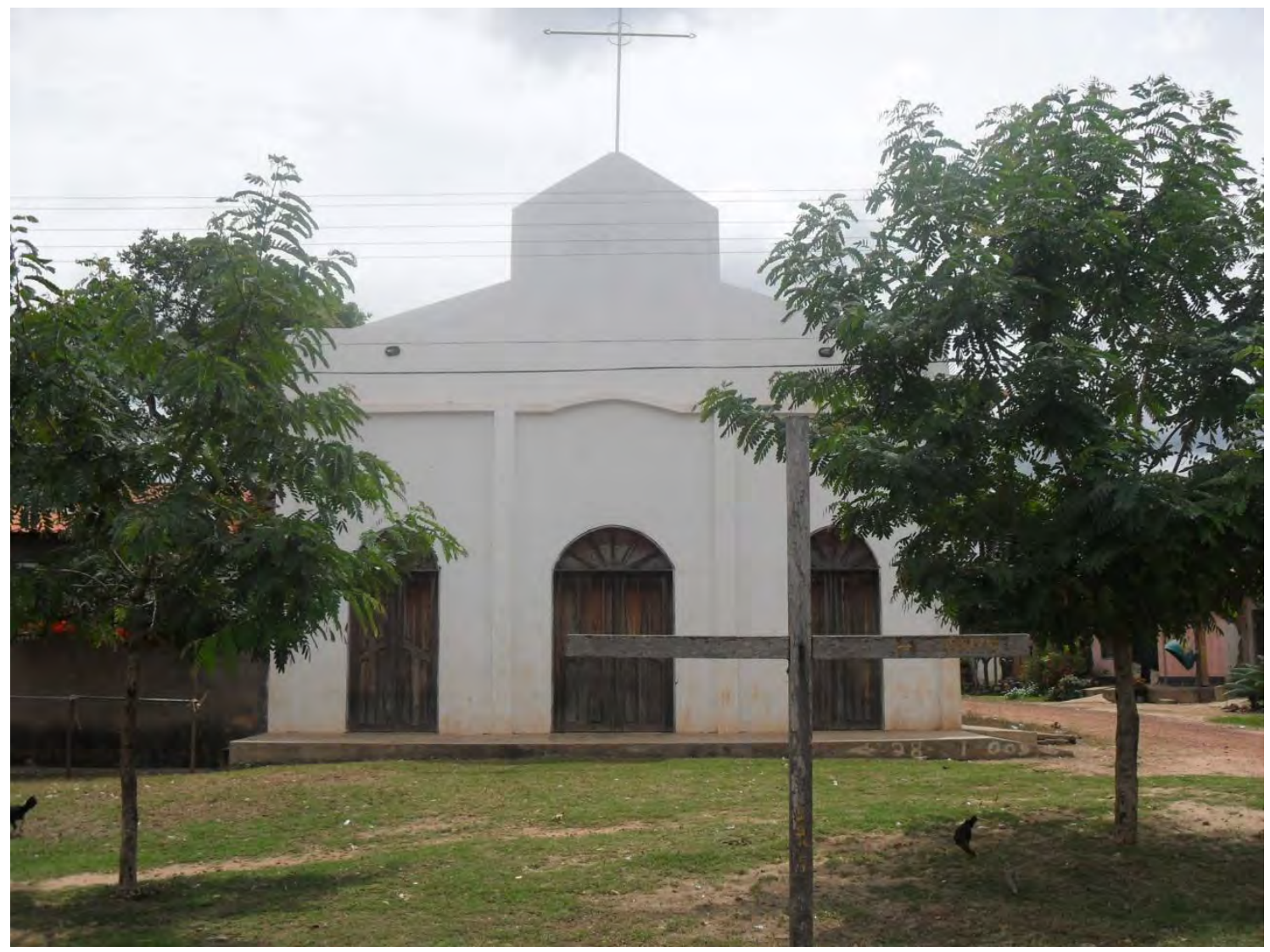

Figura 18 - Laços sagrados. Igreja de São Sebastião, no bairro do mesmo nome na cidade de Timbiras/MA.

Foto do autor, 20 de Janeiro de 2011.

Há famílias em que o nascimento dos filhos na cidade paulista, representa a oportunidade de apressar a volta da esposa para Timbiras, em razão do apoio ao cuidado maternal oferecido pelas mulheres da família, sobretudo a mãe, e pelos custos acrescentados ao já reduzido orçamento do núcleo familiar dos trabalhadores migrantes, como podemos perceber por meio do seguinte testemunho oral:

Pesquisador: Então você pensa em voltar?

Randerson: Penso em voltar. Só que dessa vez eu viajo sozinho. Ela vai ficar, porque senão vai ficar muito pesada para ela, para mim também, porque tem que deixar a criança em escola, ir buscar depois, tudo isso. E tem a família dela também, que ela não gosta muito de ficar muito longe da 
família dela, não é? Mãe dela já está meio de idade, não é? Ela não quer ficar muito longe. (Randerson, 22, casado. Testemunho oral colhido em 22/07/2011, em Guariba/SP. Caderno de Entrevistas, p. 301)

As crianças que circulam por meio das experiências migratórias dos trabalhadores e famílias maranhenses representam o próprio sentido deste processo social. As demandas por força de trabalho com elevada produtividade do trabalho requerida pelos agentes do agronegócio canavieiro, consomem a força física dos canavieiros migrantes. As maquinas agrícolas que varrem os empregos e as oportunidades de melhor ganho, empurram os trabalhadores de Timbiras para novos e velhos destinos, conhecidos ou não, da insígnia do trabalho degradante, como podemos perceber por meio do testemunho abaixo:

Tem uma observação que eu fiz, não é? Quando eu tava lá ainda, não é, conversava com uns amigos meus, não é, do barraco que a gente ficava, que a gente ficava lá alojado na cidade, eu conversava com ele, eu digo: isso vai chegar um certo tempo que vai ser que nem a febre do ouro. Agora tá sendo a febre da cana, mas vai chegar um certo tempo que também vai parar, vai ter essa redução porque já tá tendo muitas máquinas. As máquinas que cortam por cem trabalhadores num dia, não é, tem menos custo, não é, e tem maior lucratividade. Vai chegar um período em que só vai trabalhar quem já tá lá, quem tá aqui para ir para lá, eles não vão querer mais, eles vão querer pessoas que já estão lá, morando lá e já vai ter essa redução no custo da migração. A migração já não vai ser tão intensiva, não é? Aí já podem procurar outros Estados também para migrar, não é, ir procurando outras cidades como já está acontecendo agora que é o caso de Goiás, Mato Grosso que está sendo implantado bastante cana, não é? E também no próprio Maranhão, não é? Já tem bastante cidade que tem bastante cana, não é? (Antônio, 24, solteiro. Testemunho colhido em Timbiras/MA, em 18/01/2011. Caderno de Entrevistas, p.119 - 120).

As representações de suas "viagens", de sua moradia, de seu sentimento de pertença a realidade social do município maranhense revela a construção de múltiplas territorialidades migratórias em local(is) que se reproduz(em) continuamente como "destino". Múltiplas idas e vindas que não apagam, mesmo que simbolicamente, o desejo da realização territorial da permanência no território que dá sentido a sua vida e também às suas experiências migratórias. 


\section{PRADÓPOLIS E GUARIBA: O PROCESSO DE CONSTRUÇÃO DE TERRITORIALIDADES MIGRATÓRIAS DOS TRABALHADORES CANAVIEIROS}

Os deslocamentos massivos de maranhenses para o Centro-Sul do país, principalmente para as atividades da agricultura canavieira no Estado de São Paulo, ao longo dos anos 2000, possibilitaram a construção de territorialidades migratórias em diversas cidades do interior paulista, tanto em áreas mais tradicionais no cultivo da gramínea, que foram implantadas há quase um século ${ }^{15}$, como em regiões paulistas, que desde o final da década de $1970^{16}$, passavam por uma intensificação de experiências econômicas na cultura de cana-de-açúcar, motivadas pela implantação da segunda fase do Proálcool.

Mais recentemente, no final da década de 1990 e no início dos anos 2000 ocorreu uma vertiginosa expansão da cultura canavieira em municípios do noroeste e centro-oeste paulista, em especial os das regiões de governo de São José do Rio Preto, Araçatuba, Bauru e Presidente Prudente, conforme aponta Oliveira (2009, p. 120) e Thomaz Jr (2009). A ampliação das plantações da gramínea pelo país ocorreu em virtude das possibilidades de crescimento das exportações de etanol, derivada do compromisso de vários países em diminuir os lançamentos de resíduos poluentes derivados da queima do petróleo, pronunciada a partir de acordos criados em convenções internacionais, alicerçadas em torno das mudanças climáticas globais. Nesse contexto o etanol

${ }^{15} \mathrm{O}$ texto refere-se à antiga região canavieira do velho oeste paulista, que no final do século XVIII e durante o século XIX delimitou o quadrilátero do açúcar, em cujos vértices destacavam os importantes municípios produtores de Jundiaí, Mogi Mirim, Piracicaba e Sorocaba (BRAY, 1989, p. 30, 33). Nessa região surge, em 1876 o primeiro engenho-central na então província de São Paulo: a Companhia Açucareira de Porto Feliz, inaugurado em 28 de outubro de 1878 e a usina canavieira paulista mais antiga: a Usina União São Paulo, hoje Usina Rafard, pertencente ao grupo COSAN, herdeira do Engenho Central Capivari, construído em 1883, no então município de Capivari. (BRAY, 1989, p. 71, 74). CARLI (1943) aponta 38 usinas de açúcar no estado de São Paulo, no início dos anos 40, 17 delas localizadas nas proximidades do município de Piracicaba, e 10 nas cercanias de Ribeirão Preto.

16 No fim dos anos 1970 e durante a década de 1980, com a instalação da segunda fase do Programa Nacional do Álcool, regiões do país consideradas não tradicionais na plantação comercial de cana-de-açúcar foram contempladas com a instalação de destilarias autônomas, para a produção de álcool hidratado que abasteceria a maior parte dos automóveis produzidos no país no período, que circulavam a partir da queima do álcool carburante. Sobre as considerações acerca da segunda fase do Proálcool (1980 - 1985) ler BACCARIN (2005, p. 54 - 65). 
nacional despontava como "combustível alternativo" e "energia limpa" a ser fornecida ao mercado mundial.

A expansão nas vendas de automóveis bicombustíveis ${ }^{17}$ no país também contribuiu para o crescimento espantoso nas plantações da gramínea e instalação de unidades processadoras da matéria-prima, substituindo cultivos alimentares e áreas de pastagens em diversas regiões brasileiras na primeira década do século XXI (OLIVEIRA, 2009, p. 326)

Questões acerca da constituição e expansão do capital sucroenergético na primeira década dos anos 2000 e os seus reflexos direcionados ao mundo do trabalho é o que desvendaremos no início deste capítulo. Posteriormente, debruçaremos sobre a organização do agronegócio canavieiro e das condições de vida e trabalho dos canavieiros, em especial dos migrantes maranhenses, nos municípios do nordeste paulistas, tomados em tela neste trabalho: Pradópolis e Guariba.

\subsection{A Territorialização da Agroindústria Canavieira no Brasil}

\subsubsection{O contexto de expansão do agronegócio canavieiro nos anos 2000}

Nos anos 2000 ocorreu uma notável expansão da cultura canavieira no país, impulsionada pelas expectativas dos países desenvolvidos em elevar as importações do etanol nacional, devido à adoção de medidas para a redução dos lançamentos de poluentes, em correspondência com as reuniões internacionais que tinham como pauta principal a discussão dos efeitos do aquecimento global e o seu corolário: as mudanças climáticas (OLIVEIRA, 2006)

Após a divulgação e a entrada em vigor, do Protocolo de Kyoto, cresceu nos círculos governamentais, empresariais e acadêmicos o interesse pelo desenvolvimento e adoção de energias tidas como "limpa" ${ }^{18}$ com o intento de frear os lançamentos na atmosfera de gases-estufa, que contribuíam para a aceleração

\footnotetext{
17 Em 2002, as montadoras de automóveis no Brasil resolveram adotar a tecnologia Flex Fuel, ou bicombustível desenvolvida pela empresa Bosch, em sua filial na cidade de Campinas, em meados dos anos 1990. (OLIVEIRA \& VASCONCELOS, 2006, p. 70).

18 SILVA (2008, p. 10 - 12), apoiada em argumentos técnicos desmistifica a concepção da produção de etanol como "energia limpa".
} 
do aquecimento global. Dentre as principais fontes desses elementos no ar, despontava os veículos motorizados, sobretudo o automóvel, cujo consumo energético no mundo assenta-se principalmente na queima de um derivado do petróleo, a gasolina.

No plano interno, assistia-se ao desenvolvimento, e posteriormente a fabricação por parte das montadoras de modelos de automóveis bicombustíveis (flexfuel), que em poucos meses tornaram-se os mais vendidos no país, e que garantiam, assim, ao setor sucroenergético uma grande mercado para a produção de álcool hidratado, reativando as vendas de carros em função do custo inferior do etanol em relação ao derivado do hidrocarboneto.

A expectativa mundial em torno da adoção dos biocombustíveis, o crescimento das vendas de automóveis flexfuel, e posteriormente, a elevação exorbitante do barril de petróleo ${ }^{19}$ no mercado internacional gerou uma forte tendência em ampliar os mercados para o etanol brasileiro.

As plantações da gramínea estenderam-se para regiões e Estados do país, que não tinham nos cultivos de cana-de-açúcar e a produção de seus derivados, principalmente o etanol, como importante atividade agrícola e econômica.

A expansão da cultura canavieira foi mais pronunciada no noroeste do Estado de São Paulo, desalojando atividades econômicas estabelecidas firmemente desde o declínio da cafeicultura, sobretudo, a pecuária extensiva de corte, que se deslocou para a região amazônica e centro-norte do Maranhão, em busca de terras para a criação extensiva de gado, conforme colocam Oliveira (2009, p. 215), Silva (2008, p. 8) e Thomaz Jr (2009, p. 265 - 266).

A agricultura canavieira, que ganhou grande incentivo no início dos anos 1980, na segunda fase do Programa Nacional do Álcool, nas regiões administrativas de Bauru, Araçatuba, Presidente Prudente e São José do Rio Preto, cresceu de forma extraordinária, na primeira década do século XXI, a partir das unidades processadoras instaladas e dos projetos agroindustriais em implantação, que rapidamente transformavam o verde das pastagens no tom

19 Entre julho de 2007 e junho de 2008, o petróleo bruto passou de 75 dólares o barril para 140 dólares, enquanto o preço da cesta de alimentos passou de 160 dólares para 225, de acordo com o índice de Preço de Alimentos da FAO. Disponível em: http://www.fbes.org.br/index.php?option=com_content\&task=view\&id=6667\&ltemid=62. Acesso em 1 Mai 2012 
monocromático dos canaviais. A Tabela 10 mostra a quantidade moída de canade-açúcar entre as safras 2000/2001 - 2010/2011 pelo Estado de São Paulo, o maior processador nacional, pelo Centro-Sul, a região canavieira que mais esmaga a gramínea, e pelo Brasil:

Tabela 10 - Brasil, Centro-Sul Canavieiro e Estado de São Paulo. Cana moída (em toneladas) entre as safras 2000/2001 - 2010/2011.

\begin{tabular}{|c|c|c|c|}
\hline Safra & São Paulo & Centro-Sul & Brasil \\
\hline $2000 / 2001$ & 148.256 .436 & 207.099 .057 & 257.622 .017 \\
\hline $2001 / 2002$ & 176.574 .250 & 244.218 .084 & 293.050 .543 \\
\hline $2002 / 2003$ & 192.486 .643 & 270.406 .693 & 320.650 .076 \\
\hline $2003 / 2004$ & 207.810 .964 & 299.120 .591 & 359.315 .559 \\
\hline $2004 / 2005$ & 230.310 .237 & 328.727 .155 & 386.119 .910 \\
\hline $2005 / 2006$ & 242.828 .824 & 336.856 .929 & 386.584 .387 \\
\hline $2006 / 2007$ & 264.259 .457 & 372.674 .376 & 411.542 .277 \\
\hline $2007 / 2008$ & 296.242 .813 & 431.113 .603 & 495.723 .279 \\
\hline $2008 / 2009$ & 346.292 .969 & 504.962 .891 & 569.062 .629 \\
\hline $2009 / 2010$ & 400.359 .000 & 523.240 .000 & 689.895 .000 \\
\hline $2010 / 2011$ & 429.948 .709 & 556.190 .000 & 697.844 \\
\hline
\end{tabular}

Fonte: UNICA (www.unica.com.br). Acesso em 21/03/2007 / 15/07/2011

Anuário Cana 2011,

$\mathrm{Na}$ safra 2000/2001 o Estado de São Paulo foi responsável pelo esmagamento de 148.256.436 toneladas de cana-de-açúcar, o que equivaleu a $71,6 \%$ da matéria prima processada nas unidades agroindustriais da região Centro-Sul, e por $57,5 \%$ da cana moída no país. Passados dez anos, o processamento da gramínea no Estado, atingiu a marca de 429.948 .709 milhões de toneladas da matéria-prima, isto é, $77.30 \%$ das 556,19 milhões de toneladas de cana esmagada na região Centro-Sul.

Esta região produtora na safra 2010/2011 viu sua capacidade de moagem da matéria-prima ampliar 2,7 vezes, em dez anos, impulsionada também pela incorporação de novas áreas produtivas pelo agronegócio canavieiro. O Brasil, em todo o período manteve a posição de maior produtor mundial de cana-deaçúcar, processando 697.844 .000 toneladas da gramínea, crescimento 
assentado, sobretudo na capacidade de esmagamento das regiões produtoras do Centro-Sul. Podemos estender esse resultado para a produção de açúcar e de etanol (álcool anidro e hidratado) no país durante o referido período, como pode ser notado na Tabela 11 e na Tabela 12:

Tabela 11 - Brasil, Centro-Sul Canavieiro e Estado de São Paulo. Produção de açúcar (em toneladas) entre as safras 2000/2001 - 2010/2011.

\begin{tabular}{|c|c|c|c|}
\hline Safra & São Paulo & Centro-Sul & Brasil \\
\hline $2000 / 2001$ & 9.675 .481 & 12.635 .941 & 16.248 .705 \\
\hline $2001 / 2002$ & 12.350 .253 & 15.972 .162 & 19.218 .011 \\
\hline $2002 / 2003$ & 14.347 .908 & 18.778 .055 & 22.567 .260 \\
\hline $2003 / 2004$ & 15.171 .854 & 20.420 .477 & 24.925 .793 \\
\hline $2004 / 2005$ & 16.516 .346 & 22.106 .547 & 26.642 .636 \\
\hline $2005 / 2006$ & 16.762 .358 & 22.013 .573 & 25.834 .486 \\
\hline $2006 / 2007$ & 19.549 .356 & 25.830 .457 & 29.406 .520 \\
\hline $2007 / 2008$ & 19.139 .062 & 26.200 .606 & 31.026 .170 \\
\hline $2008 / 2009$ & 19.662 .436 & 26.749 .819 & 31.049 .206 \\
\hline $2009 / 2010$ & 18.800 .000 & 27.780 .000 & 33.000 .000 \\
\hline $2010 / 2011$ & 18.900 .000 & 29.000 .000 & 38.700 .000 \\
\hline
\end{tabular}

Fonte: UNICA (www.unica.com.br). Acesso em 21/03/2007 / 15/07/2011

Anuário Cana 2011.

Em dez anos a produção de açúcar no Brasil saltou de 16.248.705 toneladas para 38.700 .000 toneladas, na safra de 2010/2011. São Paulo continuou sendo a unidade da federação com a maior produção nacional, Já no que tange à produção de etanol no Brasil, o crescimento foi significativo durante as safras 2000/2001 - 2010/2011, como expõe a Tabela 12. 
Tabela 12 - Brasil, Centro-Sul Canavieiro e Estado de São Paulo. Produção de álcool anidro e hidratado $\left(\mathrm{em} \mathrm{m}^{3}\right.$ ) entre as safras 2000/2001 - 2010/2011.

\begin{tabular}{|c|c|c|c|}
\hline Safra & São Paulo & Centro-Sul & Brasil \\
\hline $2000 / 2001$ & 6.439 .113 & 9.064 .364 & 10.593 .035 \\
\hline $2001 / 2002$ & 7.134 .529 & 10.176 .290 & 11.536 .034 \\
\hline $2002 / 2003$ & 7.690 .689 & 11.152 .084 & 12.623 .225 \\
\hline $2003 / 2004$ & 8.828 .353 & 13.068 .637 & 14.808 .705 \\
\hline $2004 / 2005$ & 9.103 .940 & 13.587 .838 & 15.413 .151 \\
\hline $2005 / 2006$ & 9.951 .710 & 14.341 .430 & 15.935 .882 \\
\hline $2006 / 2007$ & 10.955 .461 & 16.053 .702 & 15.879 .424 \\
\hline $2007 / 2008$ & 13.334 .797 & 20.333 .466 & 22.526 .824 \\
\hline $2008 / 2009$ & 16.722 .478 & 25.101 .963 & 27.512 .962 \\
\hline $2009 / 2010$ & 17.0000 .000 & 23.500 .000 & 25.000 .000 \\
\hline $2010 / 2011$ & 19.000 .000 & 25.340 .000 & 27.700 .000 \\
\hline
\end{tabular}

Fonte: UNICA (www.unica.com.br). Acesso em 21/03/2007.

Anuário Cana 2001.

Na safra 2010/2011, a produção de álcool anidro e álcool hidratado do país foi 2,6 vezes superior ao total de etanol fabricado no período 2000/2001. Nestas dez safras São Paulo continuou sendo, de forma significativa, o Estado com a maior produção nacional do derivado da cana.

No que tange a produção de etanol na região Centro-Sul do país merece atenção o incremento da fabricação de novas unidades processadoras, mais modernas e com grande capacidade de esmagamento da gramínea instaladas em novas áreas em que se expandia a cultura canavieira, e que rapidamente convertia esses Estados em grandes esmagadores de cana-de-açúcar, produtores de açúcar, e principalmente de etanol no cenário brasileiro. No centrosul de Goiás, sudoeste e Triângulo Mineiro, norte do Paraná e região central sulmatogrossense, além do noroeste e do oeste paulista já referidos, as condições edafo-climáticas, logística, a infraestrutura criada, a rede de transportes além do apoio governamental contribuíram para o crescimento do agronegócio canavieiro nestas regiões. (OLIVEIRA, 2009, p. 120) 
Segundo o Jornal Cana ${ }^{20}$ na safra 2010/2011 o setor sucroenergético movimentou 60 bilhões de reais, a partir do processamento da cana, produção de açúcar e etanol, além da geração de bioeletricidade. Foram esmagadas 620 milhões de toneladas da gramínea, fabricados 38 milhões de toneladas de açúcar e 27,5 bilhões de litros de etanol. As exportações atingiram a marca de 28 milhões de toneladas de açúcar e 2 bilhões de litros de etanol, o que rendeu ao país respectivamente, 12,5 bilhões e 1bilhão de dólares. A área plantada da gramínea atingia 8,5 milhões de hectares, o que correspondeu a 3,8\% da área agricultável do país.

Do total da gramínea processada no Estado de São Paulo na safra 2010/2011, "cerca de 54\% teve como destino a produção de álcool, $43 \%$ voltou-se para a fabricação do açúcar e o restante foi para os alambiques, principalmente na regional de Guaratinguetá ${ }^{21 "}$.

A maior unidade processadora de cana-de-açúcar do país, desde a safra 2005-2006, é a Usina São Martinho ${ }^{22}$, pertencente a um dos maiores grupos do setor sucroenergético deste país. Foi instalada em 1948, em terras que compunham a Companhia Agrícola São Martinho, de propriedade da família de Martinho Prado Júnior. Dois anos depois, a unidade foi adquirida por integrantes da família Ometto, tornando-se, já na década seguinte, uma das maiores

\footnotetext{
${ }^{20}$ Fonte: Pro Cana Brasil. Disponível em< http://www.jornalcana.com.br/noticia/ProCanaBrasil/44467+Confira-nossos-numeros> Acesso em 18 Abril 201

21 De acordo com CASER, Denise Viana et al. Previsões e Estimativas das Safras Agrícolas do Estado de São Paulo, Ano Agrícola 2011/2012. Levantamento, e Levantamento Final Ano Agrícola 2010/2011, Novembro de 2011. In: Informações Econômicas V. 41, N. 12 São Paulo: Dezembro 2011. P. 51 - 52. Disponível em: ftp://ftp.sp.gov.br/ftpiea/previsao/prev-1111.pdf. Acesso em 18 Abril 2012.
}

22 O Grupo São Martinho está entre os maiores conjuntos sucroenergéticos do Brasil com três usinas em operação: São Martinho, localizada no município paulista de Pradópolis (região de Ribeirão Preto), Iracema, situada na cidade de Iracemápolis (região de Limeira, SP), e Boa Vista, em Quirinópolis, a 300 quilômetros de Goiânia, em Goiás. Além das três usinas, o Grupo possui uma unidade para produção de ácido ribonucleico, a Omtek, também localizada em Iracemápolis, e é detentor de 32,18\% da Santa Cruz - Açúcar e Álcool, localizada no município paulista de Américo Brasiliense. As usinas São Martinho e Iracema produzem açúcar e etanol enquanto a Usina Boa Vista é dedicada exclusivamente à produção de etanol. Todas elas geram energia elétrica a partir da queima do bagaço da cana, garantindo autossuficiência e venda do excedente. Já a Omtek é fabricante de derivados de levedura por meio de avançados processos biotecnológicos que atendem, principalmente, os mercados de alimentação humana e animal. Foram processados na safra 2011/2012 um total de 11,4 milhões de toneladas de cana, que resultaram em cerca de 774 mil toneladas de açúcar e 447,8 mil $\mathrm{m}^{3}$ de etanol. $O$ índice médio de mecanização da colheita do Grupo é de 85,7\%, uma referência no setor, chegando a $100 \%$ na Usina Boa Vista. Texto extraído de: http://www.saomartinho.ind.br Acesso em 18 Abr. 2012. 
unidades processadoras de cana-de-açúcar do Brasil (RAMOS, 1999, p. 132, 138).

Observe a Figura 19:

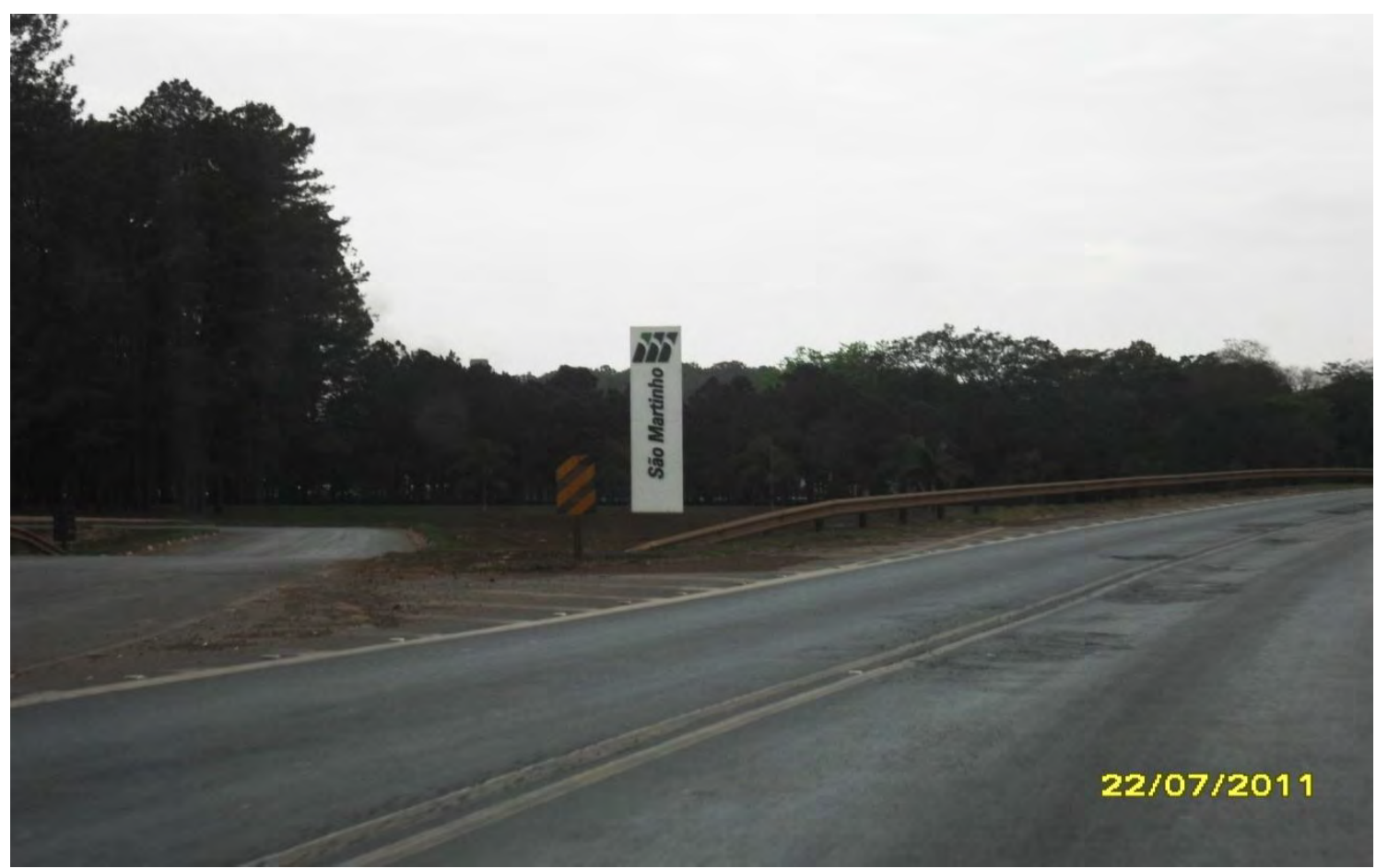

Figura 19 - Território da unidade processadora de cana-de-açúcar. Acesso da rodovia Deputado Cunha Bueno (SP 253) à Usina São Martinho, no sentido Guariba- Pradópolis.

Foto do autor, 22 de Julho de 2011.

A Usina São Martinho, situada nas proximidades da margem esquerda do rio Mogi-Guaçu, no município de Pradópolis, é também uma das unidades agroindustriais empregadoras de mão de obra migrante, procedente do Estado do Maranhão na lavoura canavieira, destacando os trabalhadores cujo núcleo familiar mora em dois municípios do leste do Estado: Timbiras e Codó. As últimas unidades processadoras que empregaram os agentes sociais entrevistados nesta pesquisa estão indicadas na Tabela 13: 
Tabela 13 - Últimas usinas empregadoras dos entrevistados.

\begin{tabular}{|l|c|}
\hline \multicolumn{1}{|c|}{ Unidade Processadora } & $\begin{array}{c}\% \text { de } \\
\text { trabalhadores }\end{array}$ \\
\hline Central Energética Moreno (SP) & $36 \%$ \\
\hline Usina Maringá (SP) & $20 \%$ \\
\hline LDC Bioenergia - São Carlos (SP) & $12 \%$ \\
\hline Usina Santa Rita (SP) & $8 \%$ \\
\hline Usina São Martinho (SP) & $4 \%$ \\
\hline Usina Albertina (SP) & $4 \%$ \\
\hline Usina Moreno - Monte Aprazível (SP) & $4 \%$ \\
\hline COPAMA (SP) & $4 \%$ \\
\hline Maity Bioenergia (MA) & $4 \%$ \\
\hline PAGRISA (PA) & $4 \%$ \\
\hline
\end{tabular}

Fonte: Pesquisa de campo.

De acordo com as informações contidas nos testemunhos orais colhidos e apontados na Tabela 13, há uma concentração de trabalhadores maranhenses em três unidades processadoras de cana-de-açúcar: a Central Energética Moreno, a Usina Maringá e a unidade São Carlos do grupo Louis Dreyfus Commodities. As unidades agroindustriais supracitadas empregaram 17 dos 25 trabalhadores migrantes, o que corresponde a $68 \%$ do total dos entrevistados.

A Central Energética Moreno, fundada em 1982, no município de Luiz Antônio, foi criada como destilaria, e posteriormente nos anos 1990 instalou também usina anexa, tornando-se uma das maiores processadoras de cana-deaçúcar do Estado de São Paulo. Compõe o grupo Moreno, que também reúne outras duas unidades agroindustriais do setor sucroenergético: a Usina Moreno, e a Usina COPLASA, erigidas nos anos 2000, impulsionada pela expansão do agronegócio canavieiro no noroeste paulista. A Usina Moreno foi instalada no município de Monte Aprazível e a Usina COPLASA, em Planalto.

A concentração de muitos empreendimentos canavieiros na região de Ribeirão Preto eleva substancialmente o preço da terra e promove a disputa entre as unidades processadoras por um incremento dos índices de produtividade agroindustriais. Esta situação oferece uma leitura ofuscante da paisagem a partir 
do domínio dos canaviais que serão esmagados por diferentes usinas, situadas nas proximidades, como podemos observar por meio da Figura 20.

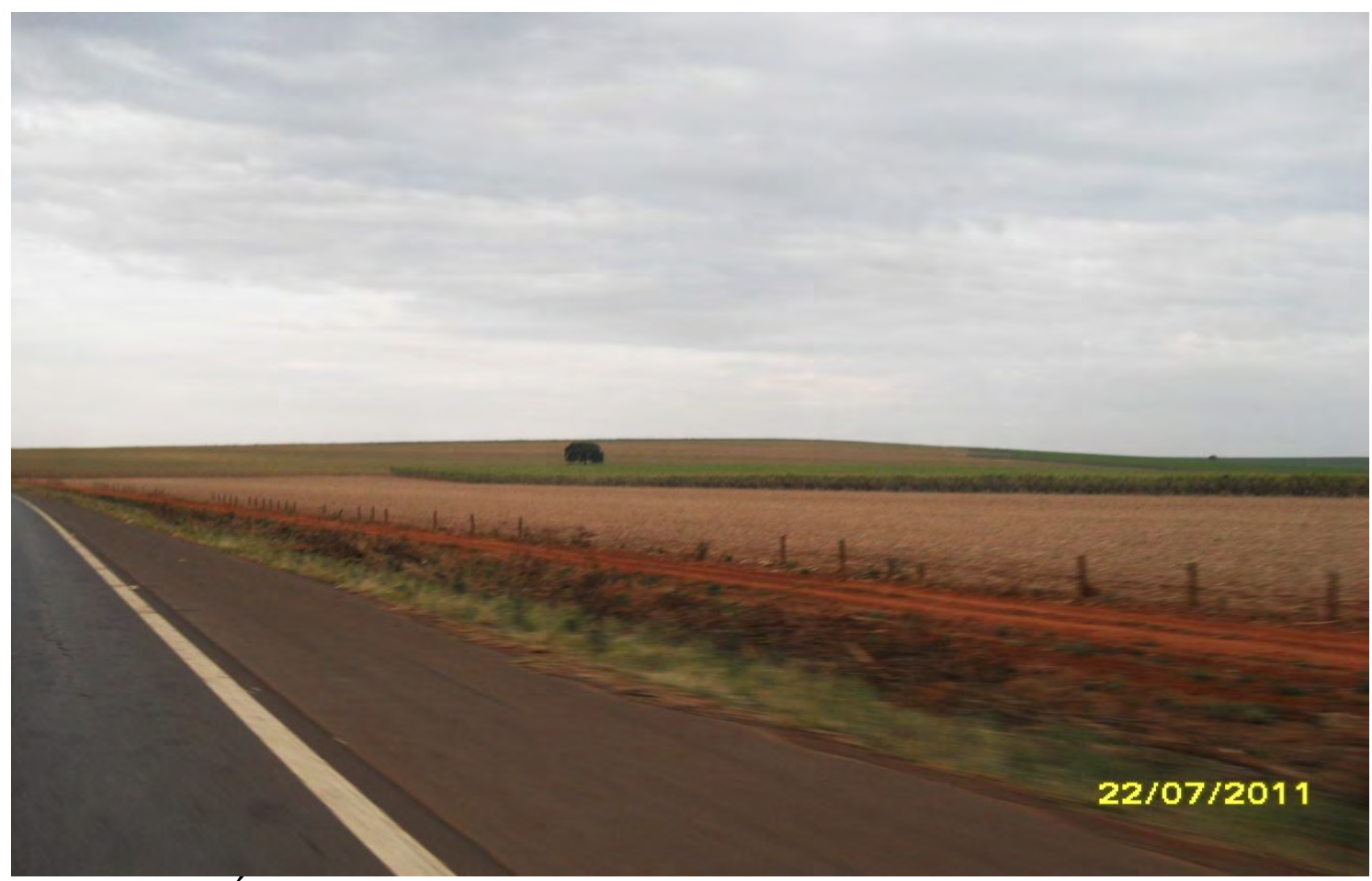

Figura 20 - Árvore solitária em meio ao mar de cana. Rodovia Deputado Cunha Bueno (SP-253), no sentido Pradópolis - Luís Antônio, no município de Guatapará/SP.

Foto do autor, 22 de Julho de 2011.

A Usina Maringá, sediada em Araraquara, e a Usina Santa Rita, instalada no município de Santa Rita do Passa Quatro, compõem o grupo Diné, que atua no setor sucroenergético, e detém além das duas usinas mencionadas, a propriedade de mais uma unidade agroindustrial canavieira, a Usina Santa Rita II, localizada no município de São Félix do Araguaia, no Estado de Mato Grosso.

A LDC Bioenergia, unidade São Carlos, situa-se no município de Jaboticabal. Foi vendida nos anos 2000 para o grupo econômico francês Louis Dreyfus $^{23}$, que nos dias de hoje é o segundo maior que atua no setor sucroenergético brasileiro, superado apenas pelo grupo Raízen ${ }^{24}$.

${ }^{23}$ O grupo Louis Dreyfus Commodities capitaneia investimentos em diversos segmentos do setor agropecuário como na produção e comercialização das produções de algodão, café, soja, citricultura, fertilizantes e sucroenergético. É o segundo maior grupo econômico que atua no Brasil no processamento de cana-de-açúcar, controlando 13 unidades agroindustriais, compondo a LDC - SEV. (Disponível em: http://www.Idcom.com.br Acesso em 2 Maio 2012) . Em outubro de 2009, a empresa francesa Louis Dreyfus Commodities anunciou a compra de cinco usinas da Santelisa 
Nos anos 2000, as unidades agroindustriais referidas também passaram por um diferenciado processo de expansão em suas capacidades de esmagamento, e produção de açúcar e etanol, como pode ser revelado, por meio da Tabela 14.

Tabela 14 - Cana-de-açúcar moída (em toneladas) pelas principais unidades processadoras que empregaram trabalhadores originários de Timbiras/MA e alocados em Guariba e Pradópolis. Safras 2001 - 2002 / 2010 - 2011.

\begin{tabular}{|l|c|c|c|c|}
\hline Unidade processadora & $2001-2002$ & $2010-2011$ & Variação absoluta & Variação (em \%) \\
\hline Central Energética Moreno & 1.696 .654 & 3.660 .567 & 1.963 .913 & $+53,7 \%$ \\
\hline Usina Maringá & 1.400 .000 & 2.348 .683 & 948.683 & $+40,4 \%$ \\
\hline LDC Bioenergia - São Carlos & 1.665 .620 & 1.775 .311 & 109.691 & $+6,2 \%$ \\
\hline Usina Santa Rita & 1.150 .000 & 2.010 .493 & 860.493 & $+42,8 \%$ \\
\hline Usina São Martinho & 5.239 .159 & 8.415 .764 & 3.176 .605 & $+37,7 \%$ \\
\hline Total produzido & 11.151 .433 & 18.810 .818 & 7.659 .385 & $+40,7 \%$ \\
\hline
\end{tabular}

Fonte: Unica (www.unica.com.br). Acesso em 29. Ago 2006. Anuário Cana 2011.

Durante a safra 2001/2002 e 2010/2011 também podemos observar, por meio da Tabela 14, a ampliação significativa da capacidade de processamento de cana-de-açúcar por parte das unidades agroindustriais referidas. $\mathrm{O}$ incremento absoluto mais marcante foi o apresentado pela Usina São Martinho, que ampliou em 3.176.605 toneladas a sua capacidade de moagem canavieira, índice apenas inferior ao total de matéria-prima esmagada pela Central Energética Moreno, na safra 2010/2011. Desta forma, a Usina São Martinho, desbancava a Usina da

Vale, na região de Ribeirão Preto (SP), para aumentar sua produção de cana no Brasil. A fusão criou o grupo LDC - SEV Bioenergia, tornando-se o segundo maior produtor mundial de açúcar e etanol. O grupo pretende produzir 40 milhões de toneladas de cana-de-açúcar por ano e tem participação acionária das famílias Biaggi e Junqueira, do Banco Nacional de Desenvolvimento Econômico e Social (BNDES) e do banco Goldman Sachs. Essa fusão aumenta para $20 \%$ a participação de empresas estrangeiras no setor. (MENDONÇA, 2010, p. 21)

${ }^{24}$ A Raízen é uma joint-venture formada entre a Shell International Petroleum Company Limited e a COSAN S/A Indústria e Comércio, aprovada pelo parecer da Secretaria de Acompanhamento Econômico do Ministério da Defesa, em 25 de novembro de 2010 (RODRIGUES, 2011, p. 12). Trata-se do maior grupo econômico do mundo no setor sucroalcooleiro, e de acordo com informações extraídas do site da joint-venture é responsável pela produção de mais de 2.2 bilhões de litros de etanol por ano para atendimento ao mercado interno e externo, 4 milhões de toneladas de açúcar e 900 MW de capacidade instalada de produção de energia elétrica a partir do bagaço da cana. Possui cerca de 4500 postos de serviço para distribuição de combustíveis espalhados pelo Brasil, mais de 500 lojas de conveniência, 53 terminais de distribuição e presente em 54 aeroportos no negócio de combustíveis de aviação. Possui 21 unidades agroindustriais no estado de São Paulo, 1 no estado do Mato Grosso do Sul e 1 em Goiás. (Fonte: http://www.raizen.com.br/pt/raizen/quem-somos.aspx Acesso em 02 Maio 2012) 
Barra, até então maior unidade do grupo Cosan, na safra 2005/2006 tornando-se a maior unidade agroindustrial em processamento de cana do país ${ }^{25}$.

Contudo, se a São Martinho convertia-se na maior usina canavieira do país, crescimentos exponenciais foram sentidos também na capacidade de moagem da gramínea da Central Energética Moreno (elevando sua capacidade produtiva em $53,7 \%$ ), da Usina Maringá (com crescimento de $40,4 \%$ no potencial de esmagamento da matéria-prima) e da Usina Santa Rita (que apresentou um aumento de $42,8 \%$ na moagem de cana). Apenas a unidade São Carlos do grupo LDC Commodities registrou uma variação menor $(6,2 \%)$ se comparado com as demais processadoras da gramínea apontadas na Tabela 14.

Contudo, no conjunto, as unidades agroindustriais canavieiras em tela ampliaram sua capacidade de moagem de cana em 40,7\%, e o total esmagado de matéria-prima por elas saltou de 11.151.433 toneladas na safra 2001/2002 para 18.810.818 de toneladas da gramínea nove safras depois.

A elevação do ritmo de processamento de cana, que trouxe como corolário o crescimento da produção de açúcar e etanol, ampliaram também o nível de produtividade agroindustrial destas empresas assenta-se em transformações de ordem técnica na lavoura canavieira que afetaram o ritmo de produção e a produtividade do trabalho nos canaviais.

A intensificação do processo de mecanização da colheita e de outras etapas do processo produtivo, apoiadas em discussões realizadas por diversos segmentos da sociedade, como empresas, sindicatos, universidades e ambientalistas, e é apoiada politicamente em acordos que sustentaram medidas para a erradicação gradual da queima da palha da cana no Estado de São Paulo. Novas plantas industriais surgiram dentro deste propósito, com a realização da colheita totalmente mecanizada.

Alves (2009, p. 161) destaca a iniciativa patronal da mecanização do corte de cana sem a criação de políticas públicas compensatórias para os trabalhadores rurais, que perderão seus precários postos de trabalho nas regiões de grande produção de cana no Estado de São Paulo.

Todavia, parte dos lucros obtidos pelas unidades processadoras decorre da exploração de uma força de trabalho migrante, cujo núcleo familiar mora em

${ }^{25}$ Fonte: Informação ÚNICA. Ano 8 Nº. 69 São Paulo: Março- Abril 2006. 
regiões empobrecidas de Estados distantes, que experimentam um histórico processo de precarização do trabalho familiar na terra, e que fora nas três últimas décadas submetidas a um violento processo de expulsão do campo e, portanto, de migração forçada para o núcleos urbanos regionais. Estes, por sua vez, ofereciam reduzidas oportunidades de emprego e garantias precárias de estabelecimento no campo, principalmente por meio da submissão à práticas limitantes de arrendamento.

Nesse sentido, foi e é a migração de milhares de trabalhadores maranhenses e de suas famílias que contribuíram, por meio de relações de superexploração do trabalho no campo para o enriquecimento das unidades processadoras e dos grupos usineiros há pouco referidos.

Conforme indica Alves (2007, p. 49):

Há forte demanda pelo CAl canavieiro paulista de trabalhadores que tenham as qualidades requeridas por seu processo de acumulação recente: elevada produtividade do trabalho; elevada capacidade física para a execução de um trabalho penoso; disponibilidade para receber baixos salários. Acredita-se também, ter demonstrado que somente as regiões onde predomina a pequena produção de subsistência e onde estão presentes os elementos do processo de expulsão dessa população que caracteriza o Processo de Acumulação Primitiva, têm condições de produzir os trabalhadores com as qualidades requeridas pelo CAI canavieiro nessa nova fase de expansão.

No discurso instrumentalizado dos empresários e agentes do agronegócio canavieiro, a expansão das plantações da gramínea é justificada pelo crescimento da lavoura de cana sobre áreas de pastagem degradada. Oliveira $(2009$, p. 326) questiona esse argumento, expondo que:

Percebe-se que apesar de certa forma, admitir que a expansão avance sobre as áreas agrícolas há sempre, por parte dos empresários e demais representantes do setor, uma preocupação em justificar o uso destas terras. Talvez como uma forma de tentar convencer a sociedade de que a cana-de-açúcar não está tomando o lugar de outras culturas, mas sim das pastagens degradadas e, assim minimizar a 
imagem negativa que paira sobre a monocultura. (OLIVEIRA, 2009, p. 326).

As considerações da autora vão ao encontro das proposições do sociólogo suíço e então relator da ONU, Jean Ziegler contidas em Silva (2008, p. 63) que declarou a produção de biocombustíveis como um "crime contra a humanidade". Segundo o autor, os cultivos de agrocombustíveis avançam sobre culturas alimentares, favorecendo a concentração de terra e renda por parte das corporações que atuam em vários segmentos do mercado financeiro e do agronegócio global.

Apoiada nesse contexto de cerceamento e controle da produção de alimentos e biocombustíveis pelas grandes corporações internacionais, Silva (2008, p. 77- 80; 2008, p. 8 - 9) sustenta o processo de reinvenção da colônia assentado na :

concentração da propriedade da terra; desnacionalização da propriedade da terra por meio da transnacionalização da apropriação da renda da terra; expropriação do campesinato existente nessas terras; insegurança alimentar nos países pobres; e esgotamento das reservas de água doce e da produtividade natural da terra em razão do volume gigantesco de agrotóxicos. (SILVA, 2008, p. 9)

Concordamos com a autora, no sentido, de que se faz primaz desmistificar a ideologia camufladora do agronegócio canavieiro e a face santificada do etanol abençoado por uma complexa rede de interesses que aglutina representantes do Estado, empresários, grande imprensa e o corpo técnico e de pesquisadores de influentes universidades e centros de pesquisa. Produz-se, portanto, um véu encobridor da realidade, que sustenta a expansão do agronegócio canavieiro como sendo a solução para questão energética mundial e a produção de divisas pelo comércio exterior do país, com o intento de suprir os compromissos financeiros do Brasil diante das organizações multilaterais e instituições do mercado financeiro internacional.

Durante os anos 2000, a expansão do setor sucroenergético pelo país também significou a junção empresarial de capitais procedentes de diferentes segmentos da economia e de outros países. 
Alves (2009, p. 159) mostra que a criação de novas unidades produtivas está associada diretamente à desnacionalização do complexo agroindustrial canavieiro. Usinas de propriedade familiar são vendidas para grandes corporações internacionais, ou seus antigos proprietários convertem-se em acionistas de organizações com capitais investidos em múltiplos segmentos do setor financeiro no mundo, capitaneando a produção de açúcar, etanol e de outros subprodutos gerados em dezenas de unidades agroindustriais no país, intensificando a concentração da produção e consequentemente o monopólio da terra, como expõe Mendonça (2010, p. 21):

Uma nova característica da indústria do etanol, se comparada ao Proálcool da década de 1970, é a aliança entre os setores do agronegócio com empresas petroleiras, automotivas, de biotecnologia, mineração, infraestrutura e fundos de investimento. Nesse cenário não existe nenhuma contradição desses setores com a oligarquia latifundista, que se beneficia da expansão do capital no campo e do abandono de um projeto de reforma agrária.

O monopólio da terra exercido pelas grandes processadoras, que também controlam o acesso aos solos de maior fertilidade natural do país, representa também a crença desmedida propagada pelos gurus do agronegócio, que procuram incutir nos corações e mentes dos mortais um sentido para justificar as atrocidades da grande produção capitalista no campo brasileiro.

Oliveira (2003, p. 122) expõe os custos dessa lógica à soberania alimentar no Brasil, sujeita à sanha agressiva do agronegócio, financiada pelo Estado em razão da produção das commodities, que garantem a geração do saldo na balança comercial destinado ao pagamento dos juros da dívida externa brasileira, recriando assim um circulo vicioso e dependente, reproduzido pela doutrina neoliberal na economia país.

Os argumentos expostos por Oliveira (2003, p. 122) são também compartilhados por Silva (2008, p. 8), que assim coloca:

No que tange ao aspecto político, o agribusiness tem sido o símbolo do desenvolvimento econômico do país, por meio do saldo positivo do comércio exterior, graças sobretudo ao aumento das exportações de produtos agrícolas que vêm 
garantindo, nos últimos anos, o pagamento dos juros da dívida externa pelo atual governo. A produção do etanol como fonte de energia tem provocado a migração de capitais internacionais tanto para a instalação de usinas como para a compra de terras. (SILVA, 2008, p. 8)

A expansão do agronegócio, defendida e difundida pelos seus fiéis escudeiros não encontram limites territoriais, desprezando ou reduzindo nas áreas incorporadas aos seus ditames "a diversidade socioambiental, assim como uma riqueza de culturas e saberes historicamente produzidos pela dinâmica social" (BEZERRA, 2009, p. 119), sepultando rapidamente a origem arcaica, violenta e excludente da grande agricultura capitalista neste país.

Converte-se tudo em terra arrasada, minimizada, ofuscada, pela sede de lucro, imposto e perpetuado a partir de múltiplas formas de violência, no que se refere à apropriação violenta da terra na microrregião de Codó, nos Cocais do Leste Maranhense.

Efeitos de uma lógica avassaladora, que avança também acelerando a movimentação e o empoderamento de grupos e agentes sociais que reivindicam a construção de uma outra territorialidade, a partir da comunhão das três concepções indissociáveis desenvolvidas por Woortmann (1990) : terra, trabalho e família. Essa territorialização materializa-se no município de Timbiras e também no de Codó, por meio do Projeto de Assentamento CIT/Novo Horizonte institucionalizado pelo INCRA e do Assentamento Horto Guarani, regulamentado em Pradópolis, pelo ITESP. Mas que também produz expulsão, pobreza e migração forçada de milhares de trabalhadores e famílias em busca de melhores condições de vida.

No que reporta a circulação dos trabalhadores migrantes de Timbiras e Codó, por diversas unidades agroindustriais da gramínea no Estado de São Paulo, 36\%, ou seja, nove dos 25 entrevistados declararam trabalhar em mais de uma usina. No entanto, 68\%, isto é, 16 maranhenses alegaram trabalhar na mesma unidade agroindustrial canavieira, residindo em Guariba ou em Pradópolis.

Em três registros orais, o trabalho na próxima safra em outro estabelecimento agroindustrial, deve-se aos desdobramentos que ocasionaram 
sucessivos boicotes ao salário dos trabalhadores rurais da extinta Central Energética Ribeirão Preto (CERP), entre os anos de 2008 e 2009.

Nem sempre safras sucessivas foram realizadas pelo trabalhador na empresa empregadora. Interrupções nestes deslocamentos para o interior paulista ocorreram, em razão da permanência no Maranhão durante 0 ano seguinte, ou até mesmo migrações intercaladas para áreas canavieiras dos estados do Maranhão e Pará, aqui representadas pelas unidades agroindustriais Maity Agroindústrial e PAGRISA (Pará Agropastoril S.A.), sediadas respectivamente nos municípios de Campestre do Maranhão, na região tocantina do Estado, e Ulianópolis, na região de influência do Grande Projeto Carajás, no Estado paraense. A quantidade de safras realizadas também varia entre os entrevistados. Observe a Tabela 15:

Tabela 15 - Período de trabalho nos canaviais, de acordo com os entrevistados.

\begin{tabular}{|l|c|c|}
\hline \multicolumn{1}{|c|}{$\begin{array}{c}\text { Período de trabalho nos } \\
\text { canaviais }\end{array}$} & $\begin{array}{c}\text { Número. de trabalhadores } \\
\text { entrevistados }\end{array}$ & Total (em \%) \\
\hline Realizando a 1 safra: & 1 & $4 \%$ \\
\hline 1 safra completa & 4 & $16 \%$ \\
\hline 1 safra incompleta & 1 & $4 \%$ \\
\hline 2 safras completas & 4 & $16 \%$ \\
\hline 2 safras incompletas & 1 & $4 \%$ \\
\hline 3 safras completas & 4 & $16 \%$ \\
\hline 4 safras completas & 2 & $8 \%$ \\
\hline 5 safras completas & 2 & $8 \%$ \\
\hline 6 safras completas & 2 & $8 \%$ \\
\hline 7safras completas & 1 & $4 \%$ \\
\hline 8 safras completas & 2 & $8 \%$ \\
\hline Sem dados & 1 & $4 \%$ \\
\hline
\end{tabular}

Fonte: Pesquisa de campo em Codó/MA e Timbiras/MA, em Janeiro de 2011. Pesquisa de campo em Guariba/SP em Outubro de 2010, Julho e Agosto de 2011. Pesquisa de campo em Pradópolis em Agosto de 2011. 
Apenas cinco trabalhadores migrantes revelaram que realizaram mais de cinco safras completas, sendo que quatro deles cumpriram as colheitas de forma sucessiva e apenas dois dentro de uma mesma usina.

A realização de sucessivas safras em uma mesma usina sinaliza a força dos agentes de aliciamento e deslocamento, que asseguram aos trabalhadores com maior produção a possibilidade se serem contratados na própria colheita. $\mathrm{O}$ contrato diferenciado dos trabalhadores migrantes, de acordo com Novaes (2007, p.93-94) determina uma segmentação entre os canavieiros. Apresentam ritmos de trabalho diferenciados, segundo a intensidade de aporte tecnológico investido na lavoura, que determina o ritmo de produtividade do trabalho, no corte manual, ou em plantações com maiores índices de mecanização nas etapas produtivas da gramínea.

São divididos também entre os "safristas", que são fichados apenas durante a colheita, e os "fixos", em menor número que exercem atividades durante a entressafra da cana, respondendo pela execução de safras sucessivas, e geralmente para uma mesma unidade processadora. Muitas vezes, o trabalhador "fixo" não "viaja" para rever a família no Maranhão durante o curto intervalo que separa o término da colheita do início do trabalho na entressafra. Noutras vezes a permanência junto à família tem duração determinada, ou é comprometida pelo adiamento do fim da safra, como ocorreu em duas unidades processadoras, de acordo com o testemunho oral dos trabalhadores migrantes, na safra 2010/2011.

A reduzida vida útil do trabalhador na atividade canavieira, em torno de quinze anos, conforme Silva (2008b, p. 13), diminui também as possibilidades da execução de dezenas de safras que acompanhavam parte significativa da vida do trabalhador rural. Nas palavras de um entrevistado:

Eu quero ficar mais um ano, e quero ir embora. 0 trabalho é pesado, já fiz cinco safras. Acho que os rapazes novos já vieram tudo, quem não veio são os mais velhos. A gente quer comprar a casa e se sobrar, a moto. (Valdenir, 25, casado. Testemunho oral colhido em 23/10/2010, na cidade de Guariba/SP. Caderno de entrevistas, p. 13) 
No entanto o esforço penoso nos canaviais, que limita a atividade dos trabalhadores com idade mais avançada, se reproduz em outras formas de trabalho degradante noutros destinos, muitos deles oferecidos pelas agências de viagem no Maranhão.

A precariedade da vida, a busca de alternativas possíveis para escapar de um permanente processo de pobreza que acompanha a história das famílias, condenam as mesmas e os seus integrantes em idade produtiva a um processo de permanente migração temporária, de acordo com as proposições de Silva (1997, p. 48). Nas palavras da autora:

Esta é a definição da migração temporária. É um eterno partir, onde parece que não se chega, porque não se pode ficar, pois migrar é preciso. O direito de ir e vir navega nas águas deste mar. O que é permanente é a migração temporária.

O consumo da força de trabalho do migrante próprio se faz dentro das determinações do capital, e não da vontade do trabalhador que foge da "precisão". O deslocamento massivo de trabalhadores migrantes de uma mesma localidade de origem para uma mesma área de destino, ao longo de certo período perfaz o que Silva (1997, p. 48) designa como corredores migratórios.

A pesquisadora percebeu o desenvolvimento destes roteiros estabelecidos ao investigar a migração de camponeses pobres de povoados de três municípios do sudoeste baiano, para o trabalho em uma mesma atividade econômica, em um mesmo polo de residência. Por meio dos testemunhos orais, pudemos confirmar as informações fornecidas pelos mediadores nos municípios maranhenses, da concentração de migrantes de Timbiras que residiam em maior número em Pradópolis, e depois em Guariba, trabalhando durante a safra, essencialmente no corte da cana. O sonho da permanência imiscui-se na permanente busca de condição, que ocasiona as migrações. De acordo com um entrevistado:

Porque aqui [Timbiras/MA] o ganho tava mais fraco, não é aí, e todo mundo ia. Eu não tinha plano de ir lá não, aí o menino, o meu primo foi primeiro do que eu, aí eu digo, eu vou experimentar lá. Eu fui em 2006, aí eu fui três anos em 
seguida, 2006, 2007 e 8, e 2009 eu não fui. Aí eu fui o ano passado, em 2010. Agora nesse ano eu não vou mais. Eu não quero ir mais não. Serviço lá é muito pesado. A gente vai assim, para melhorar, não é, pegar mais condição para ficar aqui, mas não é bom cortar cana não, eu não achei muito bom não, muito pesado. É um sol quente, eu não quero ir. (Manuel, 25, casado. Testemunho oral colhido na cidade de Timbiras/MA, em 21/01/2011. Caderno de Entrevistas, p. 275 - 276)

A migração para o trabalho nos canaviais paulistas está associada a uma organização da família na busca de melhores condições materiais, experimentando territorialidades precárias na localidade de moradia do núcleo familiar e nas cidades canavieiras paulistas, e no eito da gramínea, a partir de um acirramento da precarização das relações de trabalho.

A elevação da produtividade de trabalho durante os anos 1990 e 2000, apoiada no emprego de trabalhadores migrantes, sobretudo jovens, necessitados, sem a garantia de perspectivas de trabalho e de reprodução social na terra na região de residência de suas famílias.

A busca permanente por melhores condições de vida e de trabalho, os faz "vítimas da precisão" (Moura, 2009, p. 123), onde migrar torna-se preciso, para destinos delimitados pelas necessidades de reprodução ampliada do capital que requerem maior produtividade do trabalho, maior dispêndio de energia e força física de trabalhadores, e também de famílias inteiras, cujas vidas experimentam uma intensificação das suas já precárias condições de vida. A diminuição dos salários pagos e as degradantes relações de trabalho que marcam a vida desses trabalhadores rurais e de suas famílias é o que veremos, em seguida.

\subsubsection{O Acirramento da Precarização das Relações de Trabalho nos Canaviais do Nordeste Paulista}

Assiste-se nas duas últimas décadas nas unidades agroindustriais canavieiras do país uma elevação significativa da produtividade do trabalho nos talhões da gramínea. Alves (2007, p. 23) e Silva ( 2008b, p. 14) apontam em seus trabalhos um incremento da produtividade no corte de cana, de 5 a 8 toneladas, 
na década de 1980, que passou para 10 toneladas no decênio seguinte e índices de 12 a 15 toneladas/ cana/ homem nos anos 2000.

Desde o último quartel da década de 1990, a elevação da produtividade do trabalho está relacionada à exigência, por parte das unidades agroindustriais, de metas diárias de produção aos trabalhadores nos talhões da gramínea.

Novaes (2007, p. 110) e Silva (2008b, p. 32), porém, corroboram que esse aumento na produtividade do trabalho vem sendo incentivado por programas de treinamento, como o "Programa Cana Limpa" oferecido pelo Serviço Nacional de Aprendizagem Rural (SENAR), associado à federação patronal de agricultura paulista (FAESP), que têm por objetivo a melhoria da qualidade da matéria-prima a ser consumida no processo produtivo nas usinas e destilarias e promover o aumento do rendimento agroindustrial da cultura canavieira.

Novaes (2007, p. 110) e Silva (2008, p. 32) ainda acrescentam que iniciativas como o "Programa Cana Limpa" impõe novas prescrições e atividades no trabalho, aumentando o dispêndio físico e energético do trabalhador, mantendo inalterado, contudo os salários e as metas de produtividade diária requerida do trabalhador no eito dos canaviais.

O sentido destrutivo da lógica do capital por meio da imposição pelas usinas de médias de produtividade individual no corte manual de cana queimada resulta em deferimentos cometidos à saúde, e que põe em risco a vida do trabalhador, por meio do registro de convulsões, câimbras, paradas cardiorrespiratória e perda excessiva de nutrientes em razão das precárias condições de trabalho, e ritmo extenuantes de jornada de trabalho nos canaviais do país. Estes acontecimentos foram registrados nos estudos de Rumin (2004), Silva (2006), Alves (2006), Novaes (2007, p. 101-109) e alardearam a opinião pública a partir dos casos de 21 mortes de trabalhadores canavieiros denunciadas ao Serviço Pastoral do Migrante entre as safras de 2004 e 2009, no Estado de São Paulo.

De acordo com Alves (2006, p. 97): "O que vai ao centro da questão, que são as mortes dos trabalhadores cortadores de cana pelo excesso de trabalho, é o fim do pagamento por produção".

A exigência das metas, ou de incentivos a partir de prêmios anunciados pelas usinas acirrou a procura de cortadores de cana com elevada produtividade 
do trabalho, a partir de uma apurada seleção de trabalhadores jovens, principalmente do sexo masculino, e que dedicam desde a tenra idade nas lides da agricultura camponesa em na sua localidade de origem.

Silva (1999, p. 205) faz alusão aos "bons cortadores de cana", aos trabalhadores com elevada produção no corte de cana, reduzidos pelos agentes do capital a corpos adestrados para o trabalho duro: "Objetiva-se o aprimoramento, o perfil de um trabalhador ideal, fragmentado para tarefas fragmentadas, obediente, dócil, heterônimo".

A autora, em outro trabalho complementa:

A intensidade do trabalho, aliada ao controle de fiscais e feitores, acabam por produzir o bom cortador de cana, cujo corpo disciplinado, domesticado, repete sucessivamente movimentos de inclinar-se, levantar-se, lançar a cana, alinhá-la, limpar as impurezas ao redor dos montes, logrando assim o corte perfeito, essencial para a qualidade da matéria-prima, da diminuição dos custos de produção e aumento dos lucros da empresa. (...). (SILVA, 2008e, p. 31)

Novaes (2007, p. 97) refere-se aos trabalhadores com elevada média de produção diária no corte da cana como os "campeões de produtividade":

Nesse processo, as usinas vão formando grupos de trabalhadores selecionados, os super-homens da produção, os campeões de produtividade. Quando identificados, são muito valorizados pelas usinas e pelos empreiteiros. Podem ser contratados por tempo indeterminado ou então, terão emprego garantido nos próximos anos como trabalhadores safristas. Contudo, para entrar nesse grupo seleto é preciso cortar no mínimo dez toneladas/ dia. No novo perfil de trabalhadores para o corte manual da cana, a força e a resistência física são critérios eliminatórios. A habilidade nem tanto, visto que será adquirida no processo, logo após os primeiros meses de trabalho, caso contrário "podase". Consequentemente, idade e gênero passam a ter grande importância na seleção dos trabalhadores para o corte manual da cana. A esses dois critérios soma-se a assiduidade no trabalho.

Estes trabalhadores são requeridos pelo departamento de recursos humanos das unidades processadoras e pelos turmeiros para continuarem na 
próxima safra. Além de exibirem uma grande produção devem também ser assíduos e não se envolver em movimentos grevistas e reclamações trabalhistas na justiça. Comportamentos vigiados no território controlado pelo capital. Assim expõe um entrevistado:

É forçado, o serviço é forçado, corte de cana, para quem nunca não cortou, é se for, lá eu aguento, não é assim não! É tão tal que tem gente que vem aqui, ás vezes, passa o quê, [breve pausa] não registra a carteira, às vezes não passa um mês já vai dar baixa na carteira porque não aguenta o serviço, porque acha cansativo demais e chamam catingueiro, pois é, eu digo que é, como eu estou lhe falando, eu vou completar essas quatro safras, mas graças a Deus, dentro destas quatro safras, eu nunca fui assim um cara para faltar no serviço. (...) Mas como às vezes, o cara vem para cá, registra a carteira, aí quando chega de serviço, aí muitos, baixa na bebida, leva o domingo todo tomando, aí quando vai lembrar que trabalha é meianoite, e lá naquele dia, segunda-feira, não para em pé, e o cara, o turmeiro já vai guardando ele. Já quando chega o outro ano, ás vezes o cara procura vir, e aí aquela pessoa, o turmeiro já não quer. Esse rapaz, tem, falta muito, não serve. Porque o cara que, a usina tem a medida de todos nós tem aquela quantidade de tonelada de cana que a gente tem que cortar, todo santo dia ela já tem tudo já anotadinho. Aí aquele dia que ele não dá mais aquela quantia, ele já sabe. E só dá certo mais é dia de segunda-feira que falha. Todo dia de segunda-feira é difícil a turma ir completa, é difícil. Às vezes faltam quatro, tem vez que faltam até seis nesse local, pois é, é desse jeito aí. (Antônio Carlos, 44, casado. Testemunho oral colhido em Guariba/SP, em 24/10/2010. Caderno de entrevistas, p. 30)

O trabalhador maranhense entrevistado pode ser considerado um "bom cortador de cana", ou um "campeão de produtividade" e internaliza as medidas anunciadas pelas empresas agroindustriais no que remete às metas de produção, assiduidade e atributos negativos atribuídos aos demais trabalhadores que não seguem as recomendações da usina.

$\mathrm{Na}$ verdade, as empregadoras capturam a valorização que os trabalhadores migrantes, sobretudo os camponeses, dão ao trabalho, metamorfoseando-Ihes o sentido, dando-Ihes um conteúdo estranhado, que, no entanto, são assimilados no plano das representações, durante o trabalho no 
corte de cana, pelos trabalhadores mais produtivos. De acordo com Alves (2006, p.93):

(...) O trabalhador, quando recebe por produção, tem o seu pagamento atrelado ao que ele conseguiu produzir no dia. Como eles trabalham pela subsistência, trabalham cada vez mais para melhorar suas condições de vida; isso provoca o aumento do ritmo de trabalho. 0 pagamento por produção transfere ao trabalhador a responsabilidade pelo ritmo do trabalho, que é atribuição do capitalista. [ grifo nosso]

O autor dá relevo à transmissão de uma lógica alheia ao sentido do trabalho para o migrante no corte da cana, contribuindo para a intensificação das precárias condições de labor no eito e para abreviar o trabalhador à força de trabalho descartável, substituível, programável.

Apesar das diferentes experiências migratórias dos trabalhadores rurais, Novaes (2007, p. 111) aponta a valorização por parte destes do trabalho no corte de cana, onde a remuneração assenta-se na produção. Ainda, de acordo com o autor:

(...) Quanto mais se corta mais se ganha. Assim, os trabalhadores migrantes chegam à região com a disposição de acionar toda a sua força física, toda a sua habilidade e resistência para alcançar bons níveis de produtividade. $\mathrm{O}$ que, sem dúvida, não apenas os qualifica diante dos gestores e empresários como os justifica diante dos familiares que ficam. (NOVAES, 2007, p. 111).

A valorização dos princípios morais relativos ao trabalho, reificam a superexploração do trabalho praticada pelos agentes do capital nas unidades processadoras. A afirmação desses preceitos também se materializa com relação aos que ficam, onde o suportar um trabalho penoso nos canaviais, é estimado, ressaltando a coragem, força física, enfim valores que destacam os padrões de masculinidade, virilidade, compartilhados nas localidades de origem, que longe de se efetivarem, converte-se mais em um fardo para os trabalhadores migrantes, sobretudo dentre os camponeses pobres, que guardam uma relação de proximidade e uma ordem moral com o trabalho na terra (SILVA, 2007, p. 75). 
Vettorassi (2010, p. 194) também expõe a importância do trabalho demonstrada por migrantes piauienses, que residem em Serrana/SP, durante a colheita de cana. A autora argumenta que as redes sociais, que sustentam os deslocamentos, são mais laborais do que migratórios, pois "o projeto de migrar apenas se evidencia frente à necessidade de trabalhar", seja para onde e para qual tipo de trabalho degradante for.

A simplificação das dimensões do trabalho ao ganho, sobretudo para os trabalhadores mais competitivos, se materializam nos municípios maranhenses de maneiras distintas, dependendo do estado civil do trabalhador, ou das condições sociais de sua família. Nesse contexto, Silva (2008b, p. 15) ainda expõe outro elemento associado à produtividade do trabalho nos canaviais:

Quanto mais competitivos, mais rápidos serão os golpes de podão, capazes de lhes darem o título de "podão de ouro". Os portadores desse prêmio terão, ao final da safra, poupado o suficiente para a compra da moto, mercadoria desejada, cujo fetiche redefinirá o papel de seu possuidor na comunidade de origem. Caso seja jovem, solteiro, será visto como vitorioso, forte, destemido, valores sancionados positivamente e responsáveis pelas conquistas amorosas das jovens, cujos olhares também permanecem embaçados pelo brilho do fetiche. Caso sejam casados, o dinheiro poupado poderá ser empregado na construção da casa em alvenaria, deixando de lado a choça de adobe, coberta com folhas de babaçu ( Maranhão) ou a casinha cujas paredes são cobertas pela tabatinga (Vale do Jequitinhonha - MG). (SILVA, 2008b, p. 15)

As mudanças técnicas e organizacionais na colheita da cana também refletem uma diminuição do emprego de mulheres no trabalho nos canaviais. Apesar de muitas registrarem uma elevada média de produção diária, a exigência das metas converteu o ambiente de trabalho nos talhões da gramínea, como um espaço predominantemente masculino. Com a acentuação do processo de mecanização no corte da cana, acelera-se o processo de masculinização da força de trabalho nos canaviais. Segundo Rossini (2006, p.18):

A mudança que tem se operado em relação ao trabalho tem sido enorme. Homens e mulheres lutam pela sobrevivência 
procurando manter o trabalho durante todo $o$ ano, atividade que se torna rara a cada dia devido à mecanização intensa na agricultura. Há permanente perda de ocupação tanto para os homens como para as mulheres. Assiste-se, a cada dia, possibilidade de engajamento na força de trabalho para as pessoas mais especializadas em máquinas sofisticadas colhedeiras, tratores, caminhões e treminhões. Assim sendo, intensificam-se as masculinidades na agricultura moderna: apenas homens operam máquinas.

No que tange às trabalhadoras canavieiras, estas tiveram seus empregos significativamente reduzidos ao longo da década de 1990 e nos anos 2000, sendo hoje a minoria em várias turmas de trabalhadores rurais.

Elas foram, juntamente com os trabalhadores mais velhos, inclusive àqueles que superam a faixa dos 30 anos, os mais prejudicados por esse processo de elevação da produtividade agroindustrial que atinge os canaviais, seja por meio da intensificação do processo de mecanização, ou por meio da imposição das "médias de produção" e flexibilização dos direitos trabalhistas, negando às trabalhadoras outras dimensões de sua vida: como o direito de serem mães e o direito de se inserirem nessa outra história, contada a partir do eito dos canaviais, como comenta Silva (2004, p. 69-70):

No momento atual, esses valores do patriarcado, que imputam à mulher a condição de incapaz para o exercício de atividades pesadas voltam à tona. Protegida por esses valores, as usinas, ao não empregarem as mulheres, além de impingir-lhes o estatuto de sobrantes, apagam suas histórias enquanto trabalhadoras rurais e responsáveis em boa parte pelos níveis de acumulação de seus capitais, uma vez que sempre computaram mais de dezoito horas diárias de trabalho, em razão da dupla jornada de trabalho [...]. As mulheres são aquelas que mais foram afetadas, além dos mais velhos. Consideradas frágeis, incapazes de garantirem os níveis de produtividade no corte da cana - em torno de dez toneladas - foram relegadas às funções mais desvalorizadas e mais perigosas. A busca de outras alternativas de trabalho alia-se à consciência da situação em que vivem.

É, no entanto, na colheita da gramínea que se faz sentir, os maiores efeitos da expansão da mecanização na agroindústria canavieira. Desde a segunda 
metade da década de 1960, a maior parte da cana colhida no país, se faz a partir do corte manual da cana queimada, seguindo o sistema de "cinco ruas". O corte mecânico da gramínea seja ela crua ou queimada, adotado a partir da década de 1970, ganhou um novo salto na metade dos anos 1980, segundo Alves (1991) impelido pelas greves de trabalhadores rurais que paralisaram a produção agroindustrial de várias empresas sucroalcooleiras do Estado de São Paulo.

Nessa ocasião, a mecanização da cultura de cana-de-açúcar foi, portanto, um instrumento utilizado pelos usineiros paulistas como barganha política na contenção do movimento dos trabalhadores da agroindústria canavieira, com o fito de pressionar os mesmos, com a ameaça da perda de seus postos de trabalho para as máquinas nos talhões de cana.

Mesmo com a ameaça constante da substituição do cortador manual pelas máquinas, o custo dispendido pelas usinas, na aquisição e manutenção das mesmas, era muito superior à remuneração oferecida ao trabalhador canavieiro. Desta forma, a maior parte dos canaviais paulistas continuou sendo queimada e colhida manualmente e as máquinas, mesmo representando uma ameaça aos empregos na agricultura canavieira, permaneceram, na maior parte das unidades produtoras, conforme expressão de Graziano da Silva (1981) como "máquinas de vitrine".

Só foi, contudo, nos anos 1990, com a incorporação de novos elementos na produção sucroenergética nacional, que a mecanização foi acelerada nos canaviais do Brasil, envolvendo, primeiramente, as unidades agroindustriais mais capitalizadas que dispunham de melhores possibilidades de se adequar aos parâmetros internacionais de produção colocados para o setor econômico.

A colheita da cana-de-açúcar, realizada em sua maior parte a partir da cana queimada, colhida manualmente, passava também a ser feita por meio de três outros modos: de forma manual, a partir da cana crua; ou mecanicamente, a partir da cana queimada ou crua.

De acordo com Oliveira (2003, p.5), a principal modalidade de corte da gramínea que apresentou um notável crescimento na lavoura canavieira, em particular, na do Estado de São Paulo, foi o corte mecânico sobre a cana crua. 
A partir da segunda metade da década de 1990, as alegações de que a queima da palha da cana-de-açucar provoca efeitos maléficos sobre o meio ambiente e a sua regulamentação através do Decreto no. 42.056/97, bem como o "barateamento" das máquinas e maior aperfeiçoamento técnico, fez com que o uso da colheitadeira se ampliasse nas empresas de médio e grande porte e atingisse também as pequenas empresas. Consequentemente, houve a intensificação do corte mecanizado da cana crua.

O corte mecânico da cana crua, sobretudo nos terrenos movimentados, retira as melhores possibilidades de ganho do trabalhador, além de aumentar o dispêndio físico e energético do mesmo, principalmente por meio da curvatura acentuada da coluna vertebral nos terrenos de maior inclinação, em aclives de curvas de nível, bem como no corte da cana "pé-de-rolo", em que os vários colmos não podem ser ceifados de uma única vez.

Nota-se uma relação estreita entre as características da cana colhida e as posturas exigidas para a execução do trabalho, relação que se reflete no resultado da empreita do trabalhador e no agravamento de suas condições de trabalho, de vida e de saúde na lavoura canavieira, de acordo com Rumin (2004, p.139- 49).

O corte manual da cana crua oferece menor capacidade de produção ao trabalhador, além de acentuar os riscos de picadas de animais peçonhentos como cobras, que se abrigam nos canaviais em razão da destruição de seus habitats para o cultivo da gramínea. É preterida por vários trabalhadores entrevistados, como podemos observar por meio dos testemunhos orais registrados abaixo:

Pesquisador: E aí no caso, qual das duas você acha pior para cortar?

Domingos: Rapaz, não tem uma melhor não! Eu acho a queimada melhor, porque a crua tem pelo demais. Você é doido! Quando dava meio dia o cata tirava a roupa e tava quente de novo. Tu é doido?

(Domingos, 21, solteiro. Testemunho oral colhido em 19/01/2011, na cidade de Timbiras/MA. Caderno de Entrevistas, p. 135). 
Pesquisador: Qual que você prefere? A crua ou a queimada?

A crua ou queimada? $\mathrm{Na}$ minha opinião eu prefiro a queimada, porque a gente trabalha ali, a gente vê tudo, não é? Vê tudo na volta da gente, agora já a crua eu não gosto muito porque esse negócio de cobra, cascavel, e tudo. Porque eu mesmo já cheguei a ripar elas assim para cima, porque fica caída, as vezes a gente mete a mão assim por baixo e, a gente não vê, e a gente corre o risco de ser mordido. Eu não gosto muito de cana crua não, mas as vezes a gente corta porque é obrigação da gente, não é? A gente tá ali pra isso, mas eu não gosto muito não.

(Randerson, 22, casado. Testemunho oral colhido em 22/07/2011, na cidade de Guariba/SP. Caderno de Entrevistas, p. 308).

Pesquisador: E aí no caso, o senhor colhe cana queimada ou cana crua?

É cana queimada. Nós começamos cortando cana crua e aí um dia aí que estava proibido por fogo, porque tem um dia aí quente aí, mesmo eles proibiram e disse que a gente só ia cortar cana crua. E digo agora vai ser a vez de nós irmos embora. Porque cortar cana crua, é serviço ruim, aí graças a Deus começou, e aí eles liberaram para por fogo e aí a gente continuou cortando cana queimada. (Antônio Carlos, 44, casado. Testemunho oral colhido em 24/10/2010, na cidade de Guariba/SP. Caderno de entrevistas, p. 31)

Os pelos cortantes da palha da cana, as dificuldades para a visualização da planta a ser cortada, o risco de serem picados por animais peçonhentos e a obrigação de colher a cana crua nos talhões determinados pelos feitores e fiscais das usinas, ou por determinação dos órgãos ambientais que proíbem a queima da palha da cana nos períodos de estiagem, com baixa taxa de umidade do ar, foram alguns dos apontamentos dos entrevistados no que concerne aos problemas associados ao corte manual da cana crua.

Nas unidades agroindustriais que apresentam maiores índices de mecanização da colheita, as melhores canas são cortadas pela máquina, os piores terrenos, mais pedregosos, de maior declividade, que exigem mais esforço físico e curvatura do corpo são atribuídos aos canaviais.

A renúncia por parte dos trabalhadores entrevistados pelo trabalho no corte manual da cana crua, não torna menos penosa e isentam as dificuldades 
encontradas no corte a partir da queima da palha da cana. Silva (2008, p. 10) faz referência aos danos causados pela queima da palha de cana à saúde dos trabalhadores rurais e da população dos municípios cobertos pela monocultura canavieira:

(...) A prática das queimadas antes do corte da cana causa muitos danos à saúde dos trabalhadores e também da população urbana. Alguns desses gases vão para a atmosfera e podem reagir com a água, gerando ácidos nitrosos e sulfurosos que, com grande acumulação, podem gerar chuva ácida, prejudicial ao meio ambiente. Além desses gases há a formação de vários hidrocarbonetos ou aromáticos contendo benzeno e similares, muito prejudiciais à saúde (ZAMPERNINI, 1997; ALLEN et al., 2004; ROCHA \& FRANCO, 2003; OPPENHEIMER, et al.,2004). (...).

Os malefícios socioambientais derivados da ocorrência da queima da palha da cana, e evidenciado em estudos de diversas áreas do conhecimento, acentuaram os debates acerca do seu encerramento definitivo. Unidades processadoras, sindicatos, instâncias do poder público local, secretarias de Estado, ONGs, universidades, dentre outras instituições intensificaram as discussões, que resultaram materialmente na criação de acordos, mediados pelo governo estadual, para o estabelecimento de prazos para a cessão dessa prática agressiva adotada na colheita canavieira. Pactos foram estabelecidos, metas descumpridas, prazos ampliados, e a questão revigorada, ficando o prazo para o fim desta prática refém dos interesses dos representantes das usinas, como indica Alves (2006, p. 97):

No Brasil, a introdução do progresso técnico, mesmo quando implica a perda de milhares de postos de trabalho, não é objeto de discussão entre Capitalistas, Estado e Trabalhadores. Em geral, essa é uma decisão tomada unicamente pelos capitalistas. Embora o ônus da perda de empregos seja assumido pela sociedade como um todo, a decisão é privada. Existe, um limitante técnico à mecanização completa do corte de cana que é a declividade dos solos. A mecanização da colheita não pode ocorrer em áreas onde a declividade dos solos é maior do que $12 \%$, porque provoca riscos de tombamento das máquinas, ou a queda da produtividade do equipamento. Dada essa 
limitação técnica, difícil de ser eliminada, caso os capitalistas optem pela mecanização, terão que desocupar áreas atualmente ocupadas com a cana para ocupá-las por outras atividades que compensem as perdas de trabalho provocadas pela mecanização. Sem dúvida, apenas um processo de reforma agrária seria capaz de compensar as perdas de emprego geradas pela mecanização do corte de cana.

As metas para o fim da queima da palha de cana devem atender os interesses dos agentes envolvidos na questão, e não apenas garantir por decreto vantagens aos empresários do setor sucroenergético. $O$ autor aponta as limitações da mecanização completa em toda a área ocupada pela cultura canavieira no Estado de São Paulo, e a possibilidade de reforma agrária nas áreas não mecanizáveis como instrumento para viabilizar políticas públicas compensatórias para os cortadores de cana. Estes trabalhadores rurais terão seus empregos dizimados pela mecanização, ou suas condições de vida agravadas pelo trabalho no corte manual da cana crua, nos piores terrenos, desprezados pelas máquinas agrícolas.

Em um outro texto, o autor examina:

$\mathrm{O}$ que tem que se colocar em foco para o estabelecimento de políticas públicas compensatórias é o ritmo da mecanização que deverá se dar no mesmo ritmo da criação de novos postos de trabalho. A adequação dos ritmos entre a adoção de novas tecnologias e o estabelecimento de políticas públicas compensatórias aos empregos perdidos deve ser um dos resultados fundamentais do processo de negociação. (ALVES, 2009, p. 166)

O pesquisador apresenta a necessidade de ações que resultarão no fim da queima da cana transcender os interesses dos capitalistas do agronegócio canavieiro, que por meio da pressão política e da força econômica no Estado comprimem a direção das políticas governamentais aos seus ditames.

Alves (2009, p. 166) atenta ainda para a necessidade da criação de políticas públicas compensatórias para os cortadores de cana que perderão os 
seus empregos e não serão totalmente absorvidos com o advento total da mecanização. As ações e debates não devem centrar-se em uma iniciativa patronal (ALVES, 2009, p. 161), prescrita pelos gurus do agronegócio canavieiro, e assentado no discurso ideológico da geração de renda e riquezas ao país, discutido no início deste subcapítulo.

O autor finaliza a discussão apontando a perpetuação de uma "modernização perversa" nessas ações, "porque as novas tecnologias e de processo, ao serem implementadas, preservam e aprofundam a exploração do trabalho (ALVES,2009, p. 157). Cabe às várias instâncias e aos representantes da sociedade civil, organizar-se e impedir que as assertivas dos ideólogos do agronegócio canavieiro se tornem imperativas nas discussões que selam os rumos e as trilhas de milhares de trabalhadores rurais e de suas famílias, empobrecidos em seu município de residência, no trabalho e na passagem pelas cidades paulistas. É o que desvendaremos no subcapítulo que se segue.

\subsubsection{Os Espaços Sociais de Reprodução da Força de Trabalho Canavieira nas Cidades do Nordeste Paulista}

Os trabalhadores migrantes alocam-se, sobretudo, em residências alugadas, casas de fundo do quintal, ou pensões espalhadas pela cidade, e concentradas nos bairros periféricos das cidades. Há também alojamentos instalados em meio aos canaviais, que abrigam trabalhadores migrantes, durante a safra de cana (GEBARA, 1992; SILVA, 1999).

Segundo a coordenadora do Serviço Pastoral do Migrante em Guariba, muitos alojamentos foram desinstalados pelas usinas, e na região de abrangência da pesquisa, destaca-se apenas um deles, ocupado totalmente por trabalhadores migrantes do Vale do Jequitinhonha, no nordeste de Minas Gerais, que laboram nas plantações da gramínea moídas pela Usina Bonfim. Há, portanto, nos dias de hoje, uma concentração dos trabalhadores migrantes na sede dos principais municípios de economia fortemente vinculada à monocultura canavieira.

$O$ trabalho penoso nos talhões da gramínea negligencia do trabalhador o convívio com os demais habitantes da cidade, durante os dias da semana. A 
maioria das usinas referidas nos testemunhos orais oferece um sistema de contrato de trabalho, apoiado no descanso semanal aos domingos. Em apenas uma unidade processadora, a Central Energética Moreno, o contrato de trabalho ancora-se no sistema "cinco por um", que estabelece a folga semanal em qualquer dia da semana depois de decorridos cinco dias de trabalho. Esse sistema de trabalho foi duramente criticado nas Audiências Públicas organizadas pelo Ministério Público do Trabalho e a Delegacia Regional do Trabalho da região de Ribeirão Preto, por não permitir as práticas de sociabilidade entre os trabalhadores rurais e também no seio do núcleo familiar dos cortadores de cana já estabelecidos na cidade paulista, ou então que acompanham a migração dos trabalhadores, ao menos um dia da semana, nos domingos, com a presença e possibilidade de participação de todos.

A rotina de trabalho no eito dos canaviais inicia no alvorecer do dia, e envolve a preparação da comida que será levada no eito e o caminhar até o ponto de reunião dos trabalhadores. Os pontos de espera e os ônibus são identificados pelo nome dos turmeiros, que prestam serviços às unidades agroindustriais. Veja a Figura 21:

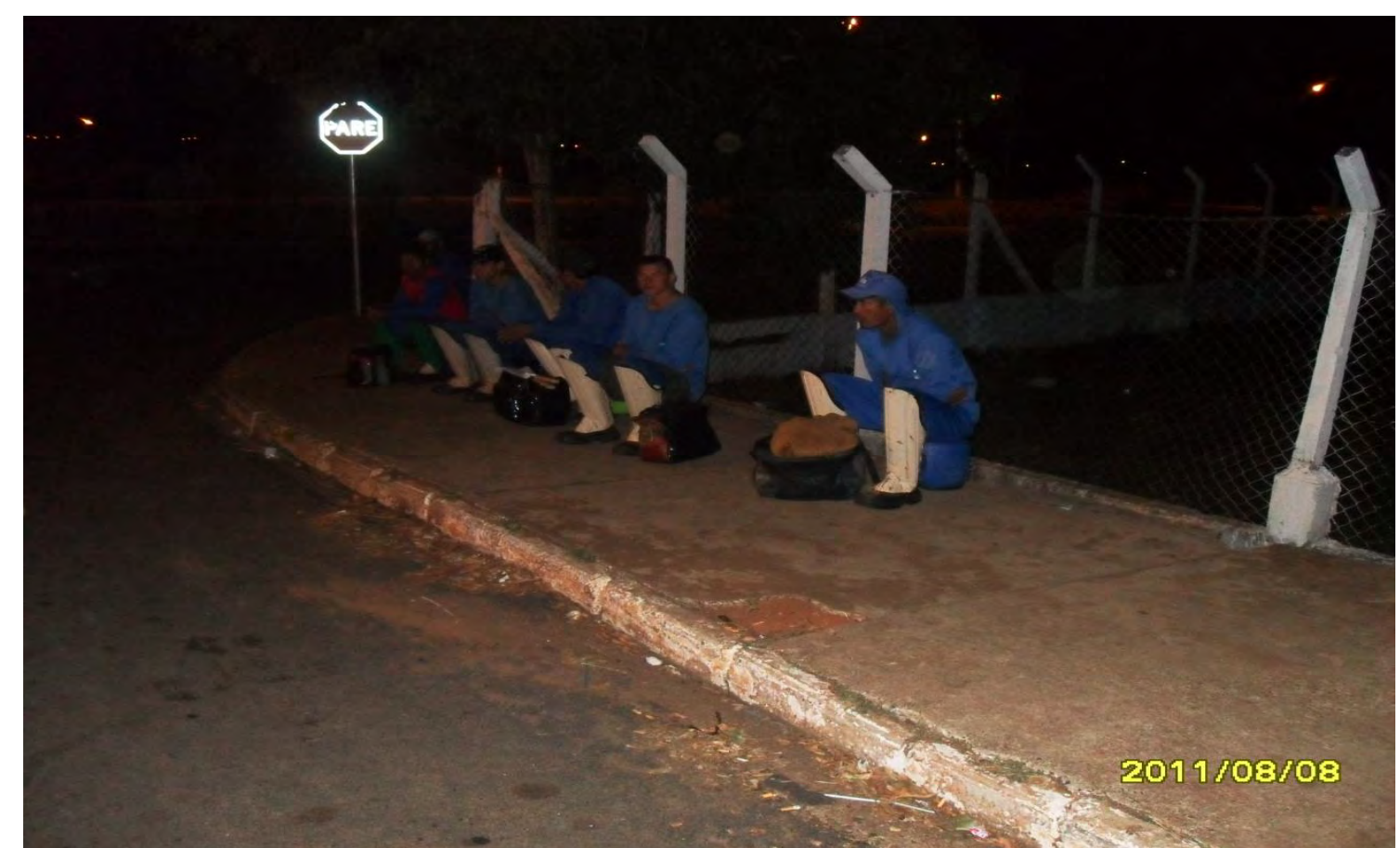

Figura 21 - Trabalho distante. Trabalhadores rurais à espera dos ônibus rurais que os conduzirão a mais um dia de labor nos canaviais e laranjais da região. Bairro Alto, Guariba/SP.

Foto do autor, 08 de agosto de 2011. 
Forma-se por volta das seis da manhã uma grande movimentação de ônibus rurais pelas ruas da cidade, cujo roteiro obedece aos pontos que congregam os trabalhadores residentes nos bairros periféricos da cidade. No interior do ônibus, homens e mulheres são conduzidos para mais uma jornada estafante de trabalho. Veja a Figura 22:

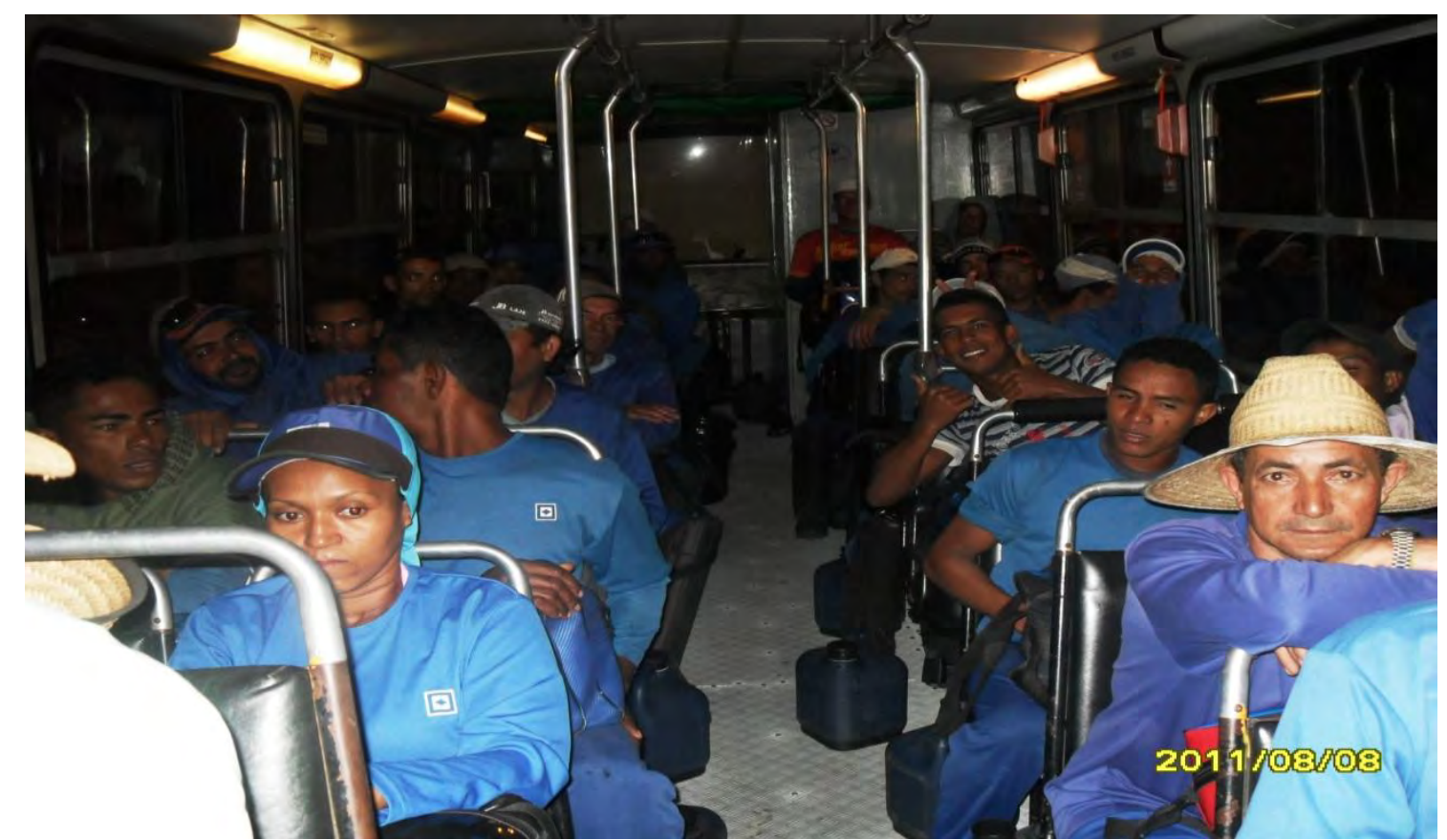

Figura 22 - Caminho para o eito. Transporte de trabalhadores canavieiros em ônibus rural, para os talhões de cana da LDC Bioenergia- unidade São Carlos. Bairro Alto, Guariba/SP.

Foto do autor, 08 de agosto de 2011.

A primeira parada no trabalho ocorre durante dez minutos, às nove da manhã para o café, e duas horas depois outra interrupção é feita para o almoço e um breve descanso que se estende durante uma hora. A terceira pausa acontece durante as duas da tarde, por dez minutos para um breve café e a última suspensão no ritmo de trabalho sucede por volta das quatro da tarde, para finalizar o serviço, anotar a produção do ganho, recolher os objetos de trabalho e partir para a casa na cidade. A sequência cotidiana no ambiente de trabalho foi registrada por meio dos testemunhos orais dos trabalhadores migrantes. Abaixo, segue o trecho da entrevista com um dos trabalhadores maranhenses: 
(...) eu acho que para mim vai ser só esse ano, eu acho que no próximo ano não venho mais para cá não, porque é sofrido demais aqui, porque a gente sofre o sofrimento da gente, a gente passa muito sono, porque todo o dia aqui nós temos que estar no ponto cinco hora da manhã, nos temos que estar no ponto, porque se a gente levanta ás vezes, faltando dez para as quatro, nós levanta para fazer a marmita, aí nós vamos para o ponto, tu vai, e o nosso ponto a gente pega bem aqui. Aí dia de chuva, rapaz! É sacrifício demais, aí quando você chega, você chega, é longe, porque as canas é longe. Tem dia que você chega aqui já são seis horas, aí a gente tem que lavar a roupa de serviço, porque a gente tem duas mudas de roupa, aí você leva uma, mas você tem que chegar e lavar aquela, que é para o outro dia, já estar no jeito. E aí eu acho muito cansativo, a gente tem muito sono, e quando dá um tempo desse, a gente, muitos não aguentam trabalhar, porque, aqui, começou a chover, muita gente diz melhorou um pouco, mas o vapor da terra sobe com aquela quenturona, que tem vez que gente que aguenta trabalhar até meio dia e de tarde já não aguenta trabalhar. (Jonas, 44, casado. Testemunho oral colhido em 24/10/2010, na cidade de Guariba/SP. Caderno de Entrevistas, p. 45)

O testemunho de Jonas revela o sofrimento da lida cotidiana do cortador de cana que levanta muito cedo para preparar a marmita para levar no eito, que tem o sono também adiado quando chega na casa e precisa realizar os serviço domésticos, como lavar a roupa que usou no trabalho, visto que é necessário ela estar enxuta no próximo dia. Jonas divide a casa alugada com outros trabalhadores maranhenses, a maioria de Codó e Timbiras. É um dos trabalhadores mais velhos da casa, e exerce uma espécie de liderança entre os moradores lá alocados. A entrevista foi realizada na tarde de um domingo, folga para a maioria dos cortadores de cana que lá residem. No seu testemunho Jonas ainda aponta a distância física dos talhões da gramínea e a demora para se deslocar dos talhões da gramínea até a casa na ligada, já no anoitecer. O calor é estafante, mesmo depois da chuva, onde as altas temperaturas e o cansaço convidam o corpo a diminuir o ritmo e a parar de trabalhar, mas a imposição das exigências do labor insiste em Ihe castigar.

Já outros trabalhadores contam com o apoio de integrantes da família, como Odair que vive com dois filhos jovens. Odair estabeleceu-se em Guariba 
desde 2003, e desde então até o encontro com o entrevistado em Codó, havia realizado oito safras completas. Ele descreve da seguinte maneira a sua rotina cotidiana para o trabalho:

Minha organização, minha filha me ajuda. Quatro e dez eu levanto. Ela não sai da cama dela também. Ela estuda pela manhã. Ela faz janta. Me ajuda. Agora, eu levanto cedo, venho na geladeira. Se tem comida, já é só aprontar. Saio para o ponto às cinco horas. Eu pego aqui pertinho também, entendeu? Chega lá bate um ranguinho cedo, nove horas, tem uns dez minutos de, nós temos, não? Nove horas parou. Volta às onze horas, fica uma hora, almoça, depois meio dia volta para o serviço, duas horas, tem mais dez minutos, e depois três e vinte, o horário de cartão, que é tudo no cartãozinho, assim. Você passa as sete horas e depois passa as onze, não é? Passa meio dia para voltar e depois passa as três para vir embora. (Odair, 37, separado. Testemunho oral colhido em 24/ 10/2010 na cidade de Guariba/SP. Caderno de Entrevistas, p. 46)

No registro oral de Odair notamos a participação da filha, contribuindo para a realização dos serviços domésticos, em especial no preparo dos alimentos. $\mathrm{O}$ entrevistado descreve a rotina de trabalho, dando realce aos momentos de interrupção para alimentar-se e ter um rápido descanso, momentos que são operacionalizados e controlados por um cartão de registro das paradas. O tempo de trabalho é o que predomina, e em uma atividade onde o ganho é por produção, faz-se o controle dos comportamentos e das necessidades físicas dos corpos maximizando-se o período de produção.

A rotina insuportável do cotidiano dos trabalhadores nos canaviais paulistas também é reproduzida por aqueles que permanecem no Maranhão. Nas palavras de uma entrevistada:

Eu ficava só com pena assim quando eu falava com ele e ele dizia assim: ei mulher mas eu tô sofrendo demais. Aquilo ali doía por dentro não é, ele dizia aquilo mulher eu to sofrendo demais aqui no São Paulo, ele dizia: esse serviço aqui é um serviço pesado, não é? Muitas vezes ele dizia assim: olha eu cheguei agorinha do serviço e ainda vou fazer de comer, eu ficava assim com pena muitas vezes até terminava eu chorando aqui não é, ele dizia : mulher você está chorando, eu digo: não ele disse está sim. Eu fico com pena assim de ver ele sofrendo mas o que tem que fazer 
não é?. (Francisca, 42, casada). Testemunho oral colhido em 16/01/2011, na cidade de Timbiras/MA. Caderno de Entrevistas, p. 82

A experiência de pobreza que acompanha a vida das famílias de trabalhadores migrantes intensifica com o sofrimento e a ausência prolongada de integrantes, que foram obrigados, pelas necessidades e dificuldades na região de origem a migrar para longe, a sujeitar-se a um serviço pesado.

A precariedade das condições de trabalho também se estende para a casa onde residem nas cidades paulistas. $\mathrm{O}$ alto preço pago pelo aluguel e as tarifas de água e energia consomem os parcos rendimentos, que também precisam ser poupados e/ou enviados aos integrantes da família que ficaram no município do leste maranhense. De acordo com Antônio:

Vou dizer assim. A coisa mais ruim lá, é o aluguel que a gente paga que ainda é muito caro. É um absurdo. $O$ aluguel mata a gente viu? Se não pagasse o aluguel lá. Oh lugarzinho bom para ganhar dinheiro!

(Francisco, 25, casado. Testemunho oral colhido em Timbiras/MA, em 19/01/2011. Caderno de Entrevistas, p. 138).

As dificuldades em pagar o aluguel comprimem o ganho dos trabalhadores migrantes, e as despesas com outras necessidades básicas dos trabalhadores como a alimentação. Todavia, a economia com a compra de alimentos pode ser compensado por produtos e alimentos originários da produção familiar na unidade camponesa, trazidos na viagem para o interior paulista, ou remetido pela família no Maranhão, por meio dos deslocamentos sazonais dos ônibus clandestinos, questão que será tratada com maior profundidade no próximo capítulo.

A precariedade, contudo não se restringe ao pagamento do aluguel e da conta de energia. A superlotação de muitas casas alugadas, reunindo muitas vezes pessoas de uma localidade de origem, ou do mesmo grupo familiar e de amigos mostram as estratégias usadas para minimizar os custos econômicos e também psicológicos do processo migratório. A precariedade das instalações e dos equipamentos na residência revela a transitoriedade, mas também a pobreza 
compartilhada pelos trabalhadores, como podemos sinalizar por meio do testemunho oral na página 140:

Pesquisador: E lá você ficava em casa alugada?

Elinaldo: Alugada.

Pesquisador: Casa alugada. Com mais quantas pessoas?

Elinaldo: Nós era oito.

Pesquisador: Oito pessoas. Você tem uma ideia do preço do aluguel que você pagava lá?

Elinaldo: Nós pagava por mês, nós pagava trezentos e setenta.

(Elinaldo, 20, solteiro. Testemunho oral colhido no povoado Pedra Preta, Timbiras/MA, em 20/01/2011. Caderno de Entrevistas, p. 198)

O preço do aluguel, em certas ocasiões cobrado individualmente, e é mencionado pelos trabalhadores como o principal obstáculo para a economia de recursos advindos pelo trabalho no corte de cana. Também indica a exploração praticada por meio de turmeiros e de agentes associados aos processos de aliciamento e deslocamento, os quais ampliam os seus rendimentos, e acirram a dependência pessoal dos trabalhadores migrantes.

No entanto, Alves (1991, p. 130), Oliveira (1984, p. 159) e Vettorassi (2006, p. 29) consideram que o preço abusivo praticado pelos supermercados ligados aos gatos, a cobrança excessiva das taxas de água e as mudanças na organização da produção "de cinco para sete ruas" eclodiram o Movimento de Guariba em maio de 1984. O somatório de carências na casa alugada em Guariba é assim retratado por um trabalhador maranhense:

Cada pessoa. Sai na faixa de noventa reais. Porque eles cobram sessenta de aluguel, aí vem a força, mais junta tudo, ás vezes dá noventa reais, certinho. Agora tem mês, não sei esse mês se vai ultrapassar porque a gente está recebendo uns talão de energia aí muito cara aí os caras dos outros barraco, o nosso ainda não chegou aqui não, mas disse que esse mês veio rachando. Não sei se este mês vai ser mais.

O aluguel e a tarifa de energia são obstáculos que se adicionam ao trabalho fatigante na lavoura, ao sono acumulado durante a semana, a dieta alimentar deficiente, a ausência dos familiares que estão distante. Quando os 
gastos na cidade de destino parecem corroer os poucos recursos economizados, a vinda da família, por mais custosa que seja para o trabalhador migrante, é ao menos desejada por muitos maranhenses que pensam em se estabelecer "definitivamente" ou passar um período mais longo labutando na lavoura de cana e residindo nas cidades do interior paulista.

Pradópolis e Guariba, na região administrativa de Ribeirão Preto, o epicentro do agronegócio canavieiro no país, estão próximas de uma grande quantidade de unidades processadoras, que exibem grande capacidade de produção agroindustrial e elevada produtividade do trabalho. Nelas residem centenas e milhares de trabalhadores migrantes, procedentes de outros Estados.

A territorialização do capital agroindustrial, o controle social, político e econômico exercido pelas usinas, não impingem marcas e contornos definitivos na história e na vida desses municípios paulistas. Guariba e Pradópolis não podem tampouco ser reduzidas à produção de territorialidades precárias para os trabalhadores. Materializam de forma significativa a territorialização da resistência, imortalizada no movimento de maio de 1984, emblemático na história e luta dos assalariados rurais do país, e na territorialização camponesa na sombra da maior processadora de cana de açúcar do mundo: a Usina São Martinho. As cidades referência para os usineiros também se tornaram modelo e converteramse em espaços sociais de exercício do contrapoder (SILVA, 1999). A complexidade e as controvérsias dessas faces dos municípios paulistas é o que debruçaremos na análise a seguir.

\subsection{Pradópolis e Guariba: o Processo de Construção de Territorialidades Migratórias dos Trabalhadores Canavieiros.}

Dentre os municípios paulistas, nos primeiros anos do século $\mathrm{XXI}$, dois chamavam a atenção pelo número de trabalhadores maranhenses abrigados em seu núcleo urbano, e que laboravam em várias usinas da região. Eles eram Pradópolis e Guariba, no nordeste do Estado de São Paulo. No último, a presença de maranhenses hoje é dominante, principalmente dos procedentes de três municípios do leste do Estado: Coroatá, Codó e Timbiras. Já na cidade de 
Pradópolis, o predomínio de maranhenses que para lá iam, partiam principalmente do município de Timbiras. É sobre o processo de construção de territórios de migração maranhense, em particular de Timbiras, nesses dois municípios do Estado de São Paulo e a importância da cana-de-açúcar em várias esferas de sua vida política, econômica e social que discutiremos com profundidade a seguir.

\subsubsection{Pradópolis}

A cidade de Pradópolis está localizada a 336 quilômetros da metrópole paulistana é o principal ponto de destino de cortadores de cana originários de Timbiras, no Maranhão. O município contava em 2010, de acordo com o último Censo Demográfico com 17.404 habitantes, 92,7\% dos quais residentes no núcleo urbano. Comunica-se com a sede do município limítrofe de Ribeirão Preto, a mais importante cidade do nordeste do Estado de São Paulo, por meio da rodovia SP 291há 36 quilômetros do núcleo urbano pradopolitano. Também tem acesso pela SP 253 à sede do município de Guariba, segundo município paulista, envolvido na pesquisa, há 17 quilômetros de Pradópolis.

A proximidade geográfica de Ribeirão Preto, a conexão com importantes eixos rodoviários que faz a ligação da cidade com outras sedes de município e unidades agroindustriais canavieiras nas cercanias, posiciona Pradópolis no coração do agronegócio canavieiro do país. Cercada por canaviais e sede da maior processadora de cana-de-açúcar do mundo, o município pradopolitano revela desde os primórdios de sua constituição econômica, uma relação estreita com a grande propriedade, a força de trabalho migrante e com as redes de transporte fundamentais para o escoamento da produção agrícola regional. Veja o Mapa 9. 
LOCALIZAÇÃo DO MUNICÍPIO DE PRADÓPOLIS

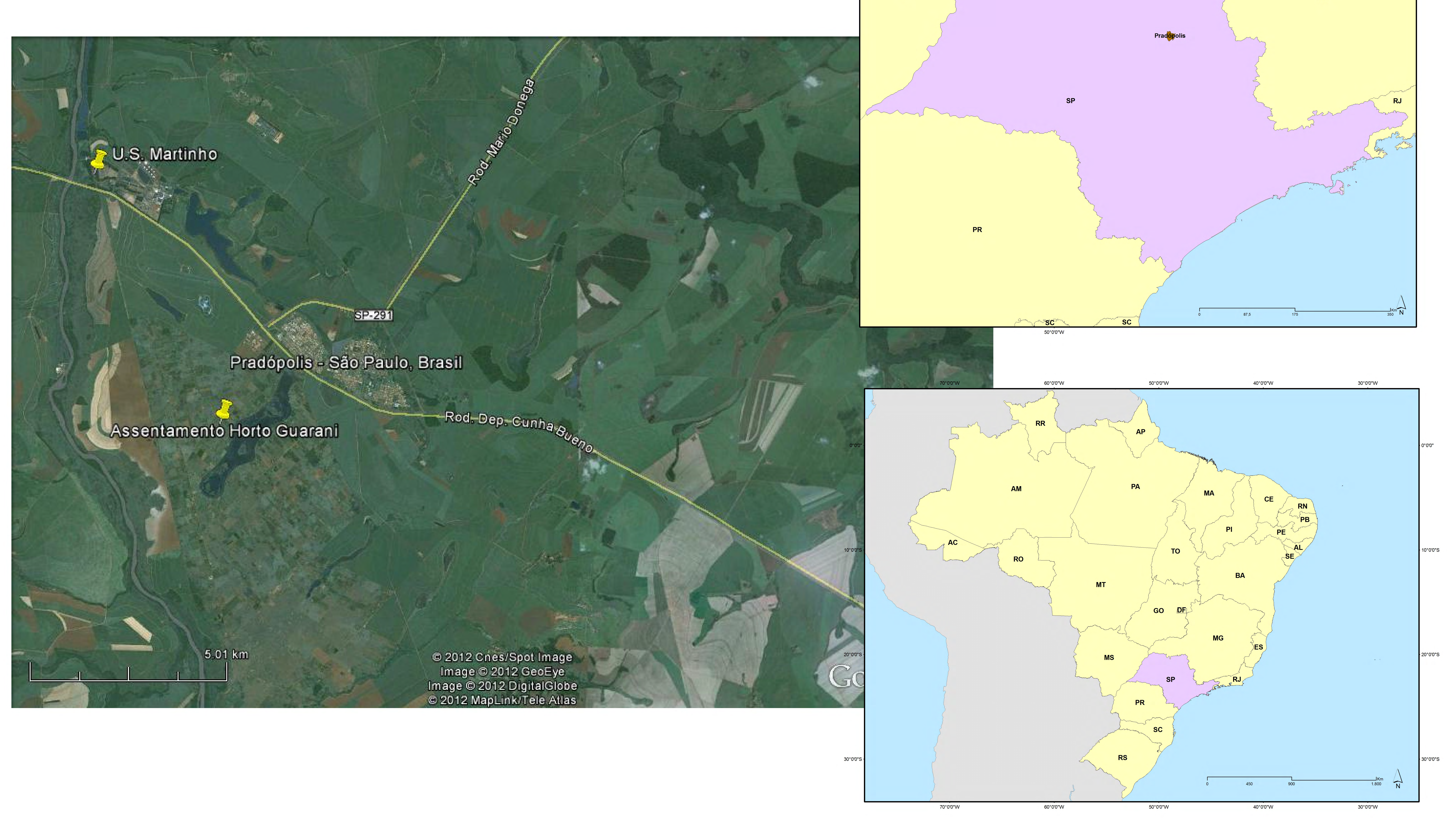


O topônimo da cidade, de certa forma, revela os elementos estruturais que marcam a história do município: a grande lavoura de café, sobretudo, no período em que foi administrada por Martinho Prado Júnior, de 1889 a 1948, a força de trabalho imigrante na colheita e tratos culturais da rubiácea, e os trilhos da companhia ferroviária Estrada de Ferro Paulista.

Contudo, a intensificação do povoamento luso-brasileiro na área que compõem hoje o município de Pradópolis se desenvolveu a partir da migração de famílias que se deslocaram do chamado Sul Mineiro, em especial da comarca do Rio das Mortes, na última década do século XVIII, á procura de novas terras e da expansão de suas atividades econômicas, notadamente a criação de gado, em razão do declínio da produção aurífera na então capitania de Minas Gerais (Brioschi, 1999, p. 59 - 60,70).

Esse deslocamento de grupos familiares representou também a requisição de sesmarias, ou a posse de grandes extensões de terra, e o maior grupo familiar de origem mineira estabelecido no nordeste paulista, na região conhecida como "Sertão do Rio Pardo" foram os Junqueira, apoderando-se das maiores glebas compradas ou apossadas na região (Brioschi, 1999, p. 67).

Dentre as terras incorporadas pela família destaca-se os 68 mil alqueires da Fazenda Lageado, ocupando uma área hoje pertencentes aos municípios de Luis Antônio, Pradópolis, Barrinha e Guatapará, compradas por Luís Antônio de Souza Diniz e sua prima e mulher Ana Claudina Diniz Junqueira. (Brioschi, 1999, p. 67). Veja o Mapa 10. 


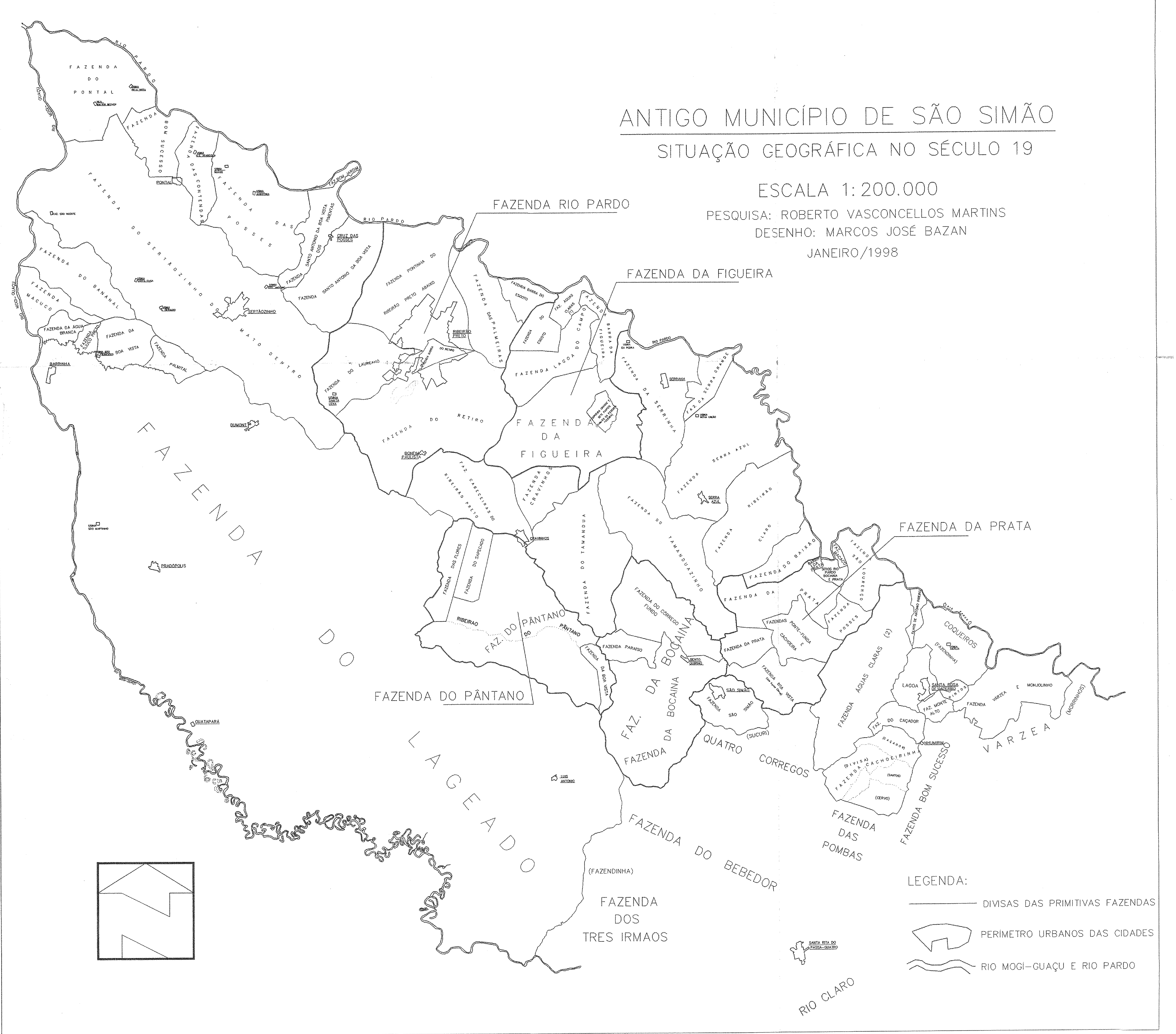


corte de cana, pelos trabalhadores mais produtivos. De acordo com Alves (2006, p.93):

(...) O trabalhador, quando recebe por produção, tem o seu pagamento atrelado ao que ele conseguiu produzir no dia. Como eles trabalham pela subsistência, trabalham cada vez mais para melhorar suas condições de vida; isso provoca o aumento do ritmo de trabalho. 0 pagamento por produção transfere ao trabalhador a responsabilidade pelo ritmo do trabalho, que é atribuição do capitalista. [ grifo nosso]

O autor dá relevo à transmissão de uma lógica alheia ao sentido do trabalho para o migrante no corte da cana, contribuindo para a intensificação das precárias condições de labor no eito e para abreviar o trabalhador à força de trabalho descartável, substituível, programável.

Apesar das diferentes experiências migratórias dos trabalhadores rurais, Novaes (2007, p. 111) aponta a valorização por parte destes do trabalho no corte de cana, onde a remuneração assenta-se na produção. Ainda, de acordo com o autor:

(...) Quanto mais se corta mais se ganha. Assim, os trabalhadores migrantes chegam à região com a disposição de acionar toda a sua força física, toda a sua habilidade e resistência para alcançar bons níveis de produtividade. $\mathrm{O}$ que, sem dúvida, não apenas os qualifica diante dos gestores e empresários como os justifica diante dos familiares que ficam. (NOVAES, 2007, p. 111).

A valorização dos princípios morais relativos ao trabalho, reificam a superexploração do trabalho praticada pelos agentes do capital nas unidades processadoras. A afirmação desses preceitos também se materializa com relação aos que ficam, onde o suportar um trabalho penoso nos canaviais, é estimado, ressaltando a coragem, força física, enfim valores que destacam os padrões de masculinidade, virilidade, compartilhados nas localidades de origem, que longe de se efetivarem, converte-se mais em um fardo para os trabalhadores migrantes, sobretudo dentre os camponeses pobres, que guardam uma relação de proximidade e uma ordem moral com o trabalho na terra (SILVA, 2007, p. 75). 
Vettorassi (2010, p. 194) também expõe a importância do trabalho demonstrada por migrantes piauienses, que residem em Serrana/SP, durante a colheita de cana. A autora argumenta que as redes sociais, que sustentam os deslocamentos, são mais laborais do que migratórios, pois "o projeto de migrar apenas se evidencia frente à necessidade de trabalhar", seja para onde e para qual tipo de trabalho degradante for.

A simplificação das dimensões do trabalho ao ganho, sobretudo para os trabalhadores mais competitivos, se materializam nos municípios maranhenses de maneiras distintas, dependendo do estado civil do trabalhador, ou das condições sociais de sua família. Nesse contexto, Silva (2008b, p. 15) ainda expõe outro elemento associado à produtividade do trabalho nos canaviais:

Quanto mais competitivos, mais rápidos serão os golpes de podão, capazes de lhes darem o título de "podão de ouro". Os portadores desse prêmio terão, ao final da safra, poupado o suficiente para a compra da moto, mercadoria desejada, cujo fetiche redefinirá o papel de seu possuidor na comunidade de origem. Caso seja jovem, solteiro, será visto como vitorioso, forte, destemido, valores sancionados positivamente e responsáveis pelas conquistas amorosas das jovens, cujos olhares também permanecem embaçados pelo brilho do fetiche. Caso sejam casados, o dinheiro poupado poderá ser empregado na construção da casa em alvenaria, deixando de lado a choça de adobe, coberta com folhas de babaçu ( Maranhão) ou a casinha cujas paredes são cobertas pela tabatinga (Vale do Jequitinhonha - MG). (SILVA, 2008b, p. 15)

As mudanças técnicas e organizacionais na colheita da cana também refletem uma diminuição do emprego de mulheres no trabalho nos canaviais. Apesar de muitas registrarem uma elevada média de produção diária, a exigência das metas converteu o ambiente de trabalho nos talhões da gramínea, como um espaço predominantemente masculino. Com a acentuação do processo de mecanização no corte da cana, acelera-se o processo de masculinização da força de trabalho nos canaviais. Segundo Rossini (2006, p.18):

A mudança que tem se operado em relação ao trabalho tem sido enorme. Homens e mulheres lutam pela sobrevivência 
procurando manter o trabalho durante todo $o$ ano, atividade que se torna rara a cada dia devido à mecanização intensa na agricultura. Há permanente perda de ocupação tanto para os homens como para as mulheres. Assiste-se, a cada dia, possibilidade de engajamento na força de trabalho para as pessoas mais especializadas em máquinas sofisticadas colhedeiras, tratores, caminhões e treminhões. Assim sendo, intensificam-se as masculinidades na agricultura moderna: apenas homens operam máquinas.

No que tange às trabalhadoras canavieiras, estas tiveram seus empregos significativamente reduzidos ao longo da década de 1990 e nos anos 2000, sendo hoje a minoria em várias turmas de trabalhadores rurais.

Elas foram, juntamente com os trabalhadores mais velhos, inclusive àqueles que superam a faixa dos 30 anos, os mais prejudicados por esse processo de elevação da produtividade agroindustrial que atinge os canaviais, seja por meio da intensificação do processo de mecanização, ou por meio da imposição das "médias de produção" e flexibilização dos direitos trabalhistas, negando às trabalhadoras outras dimensões de sua vida: como o direito de serem mães e o direito de se inserirem nessa outra história, contada a partir do eito dos canaviais, como comenta Silva (2004, p. 69-70):

No momento atual, esses valores do patriarcado, que imputam à mulher a condição de incapaz para o exercício de atividades pesadas voltam à tona. Protegida por esses valores, as usinas, ao não empregarem as mulheres, além de impingir-lhes o estatuto de sobrantes, apagam suas histórias enquanto trabalhadoras rurais e responsáveis em boa parte pelos níveis de acumulação de seus capitais, uma vez que sempre computaram mais de dezoito horas diárias de trabalho, em razão da dupla jornada de trabalho [...]. As mulheres são aquelas que mais foram afetadas, além dos mais velhos. Consideradas frágeis, incapazes de garantirem os níveis de produtividade no corte da cana - em torno de dez toneladas - foram relegadas às funções mais desvalorizadas e mais perigosas. A busca de outras alternativas de trabalho alia-se à consciência da situação em que vivem.

É, no entanto, na colheita da gramínea que se faz sentir, os maiores efeitos da expansão da mecanização na agroindústria canavieira. Desde a segunda 
metade da década de 1960, a maior parte da cana colhida no país, se faz a partir do corte manual da cana queimada, seguindo o sistema de "cinco ruas". O corte mecânico da gramínea seja ela crua ou queimada, adotado a partir da década de 1970, ganhou um novo salto na metade dos anos 1980, segundo Alves (1991) impelido pelas greves de trabalhadores rurais que paralisaram a produção agroindustrial de várias empresas sucroalcooleiras do Estado de São Paulo.

Nessa ocasião, a mecanização da cultura de cana-de-açúcar foi, portanto, um instrumento utilizado pelos usineiros paulistas como barganha política na contenção do movimento dos trabalhadores da agroindústria canavieira, com o fito de pressionar os mesmos, com a ameaça da perda de seus postos de trabalho para as máquinas nos talhões de cana.

Mesmo com a ameaça constante da substituição do cortador manual pelas máquinas, o custo dispendido pelas usinas, na aquisição e manutenção das mesmas, era muito superior à remuneração oferecida ao trabalhador canavieiro. Desta forma, a maior parte dos canaviais paulistas continuou sendo queimada e colhida manualmente e as máquinas, mesmo representando uma ameaça aos empregos na agricultura canavieira, permaneceram, na maior parte das unidades produtoras, conforme expressão de Graziano da Silva (1981) como "máquinas de vitrine".

Só foi, contudo, nos anos 1990, com a incorporação de novos elementos na produção sucroenergética nacional, que a mecanização foi acelerada nos canaviais do Brasil, envolvendo, primeiramente, as unidades agroindustriais mais capitalizadas que dispunham de melhores possibilidades de se adequar aos parâmetros internacionais de produção colocados para o setor econômico.

A colheita da cana-de-açúcar, realizada em sua maior parte a partir da cana queimada, colhida manualmente, passava também a ser feita por meio de três outros modos: de forma manual, a partir da cana crua; ou mecanicamente, a partir da cana queimada ou crua.

De acordo com Oliveira (2003, p.5), a principal modalidade de corte da gramínea que apresentou um notável crescimento na lavoura canavieira, em particular, na do Estado de São Paulo, foi o corte mecânico sobre a cana crua. 
A partir da segunda metade da década de 1990, as alegações de que a queima da palha da cana-de-açucar provoca efeitos maléficos sobre o meio ambiente e a sua regulamentação através do Decreto no. 42.056/97, bem como o "barateamento" das máquinas e maior aperfeiçoamento técnico, fez com que o uso da colheitadeira se ampliasse nas empresas de médio e grande porte e atingisse também as pequenas empresas. Consequentemente, houve a intensificação do corte mecanizado da cana crua.

O corte mecânico da cana crua, sobretudo nos terrenos movimentados, retira as melhores possibilidades de ganho do trabalhador, além de aumentar o dispêndio físico e energético do mesmo, principalmente por meio da curvatura acentuada da coluna vertebral nos terrenos de maior inclinação, em aclives de curvas de nível, bem como no corte da cana "pé-de-rolo", em que os vários colmos não podem ser ceifados de uma única vez.

Nota-se uma relação estreita entre as características da cana colhida e as posturas exigidas para a execução do trabalho, relação que se reflete no resultado da empreita do trabalhador e no agravamento de suas condições de trabalho, de vida e de saúde na lavoura canavieira, de acordo com Rumin (2004, p.139- 49).

O corte manual da cana crua oferece menor capacidade de produção ao trabalhador, além de acentuar os riscos de picadas de animais peçonhentos como cobras, que se abrigam nos canaviais em razão da destruição de seus habitats para o cultivo da gramínea. É preterida por vários trabalhadores entrevistados, como podemos observar por meio dos testemunhos orais registrados abaixo:

Pesquisador: E aí no caso, qual das duas você acha pior para cortar?

Domingos: Rapaz, não tem uma melhor não! Eu acho a queimada melhor, porque a crua tem pelo demais. Você é doido! Quando dava meio dia o cata tirava a roupa e tava quente de novo. Tu é doido?

(Domingos, 21, solteiro. Testemunho oral colhido em 19/01/2011, na cidade de Timbiras/MA. Caderno de Entrevistas, p. 135). 
Pesquisador: Qual que você prefere? A crua ou a queimada?

A crua ou queimada? $\mathrm{Na}$ minha opinião eu prefiro a queimada, porque a gente trabalha ali, a gente vê tudo, não é? Vê tudo na volta da gente, agora já a crua eu não gosto muito porque esse negócio de cobra, cascavel, e tudo. Porque eu mesmo já cheguei a ripar elas assim para cima, porque fica caída, as vezes a gente mete a mão assim por baixo e, a gente não vê, e a gente corre o risco de ser mordido. Eu não gosto muito de cana crua não, mas as vezes a gente corta porque é obrigação da gente, não é? A gente tá ali pra isso, mas eu não gosto muito não.

(Randerson, 22, casado. Testemunho oral colhido em 22/07/2011, na cidade de Guariba/SP. Caderno de Entrevistas, p. 308).

Pesquisador: E aí no caso, o senhor colhe cana queimada ou cana crua?

É cana queimada. Nós começamos cortando cana crua e aí um dia aí que estava proibido por fogo, porque tem um dia aí quente aí, mesmo eles proibiram e disse que a gente só ia cortar cana crua. E digo agora vai ser a vez de nós irmos embora. Porque cortar cana crua, é serviço ruim, aí graças a Deus começou, e aí eles liberaram para por fogo e aí a gente continuou cortando cana queimada. (Antônio Carlos, 44, casado. Testemunho oral colhido em 24/10/2010, na cidade de Guariba/SP. Caderno de entrevistas, p. 31)

Os pelos cortantes da palha da cana, as dificuldades para a visualização da planta a ser cortada, o risco de serem picados por animais peçonhentos e a obrigação de colher a cana crua nos talhões determinados pelos feitores e fiscais das usinas, ou por determinação dos órgãos ambientais que proíbem a queima da palha da cana nos períodos de estiagem, com baixa taxa de umidade do ar, foram alguns dos apontamentos dos entrevistados no que concerne aos problemas associados ao corte manual da cana crua.

Nas unidades agroindustriais que apresentam maiores índices de mecanização da colheita, as melhores canas são cortadas pela máquina, os piores terrenos, mais pedregosos, de maior declividade, que exigem mais esforço físico e curvatura do corpo são atribuídos aos canaviais.

A renúncia por parte dos trabalhadores entrevistados pelo trabalho no corte manual da cana crua, não torna menos penosa e isentam as dificuldades 
encontradas no corte a partir da queima da palha da cana. Silva (2008, p. 10) faz referência aos danos causados pela queima da palha de cana à saúde dos trabalhadores rurais e da população dos municípios cobertos pela monocultura canavieira:

(...) A prática das queimadas antes do corte da cana causa muitos danos à saúde dos trabalhadores e também da população urbana. Alguns desses gases vão para a atmosfera e podem reagir com a água, gerando ácidos nitrosos e sulfurosos que, com grande acumulação, podem gerar chuva ácida, prejudicial ao meio ambiente. Além desses gases há a formação de vários hidrocarbonetos ou aromáticos contendo benzeno e similares, muito prejudiciais à saúde (ZAMPERNINI, 1997; ALLEN et al., 2004; ROCHA \& FRANCO, 2003; OPPENHEIMER, et al.,2004). (...).

Os malefícios socioambientais derivados da ocorrência da queima da palha da cana, e evidenciado em estudos de diversas áreas do conhecimento, acentuaram os debates acerca do seu encerramento definitivo. Unidades processadoras, sindicatos, instâncias do poder público local, secretarias de Estado, ONGs, universidades, dentre outras instituições intensificaram as discussões, que resultaram materialmente na criação de acordos, mediados pelo governo estadual, para o estabelecimento de prazos para a cessão dessa prática agressiva adotada na colheita canavieira. Pactos foram estabelecidos, metas descumpridas, prazos ampliados, e a questão revigorada, ficando o prazo para o fim desta prática refém dos interesses dos representantes das usinas, como indica Alves (2006, p. 97):

No Brasil, a introdução do progresso técnico, mesmo quando implica a perda de milhares de postos de trabalho, não é objeto de discussão entre Capitalistas, Estado e Trabalhadores. Em geral, essa é uma decisão tomada unicamente pelos capitalistas. Embora o ônus da perda de empregos seja assumido pela sociedade como um todo, a decisão é privada. Existe, um limitante técnico à mecanização completa do corte de cana que é a declividade dos solos. A mecanização da colheita não pode ocorrer em áreas onde a declividade dos solos é maior do que $12 \%$, porque provoca riscos de tombamento das máquinas, ou a queda da produtividade do equipamento. Dada essa 
limitação técnica, difícil de ser eliminada, caso os capitalistas optem pela mecanização, terão que desocupar áreas atualmente ocupadas com a cana para ocupá-las por outras atividades que compensem as perdas de trabalho provocadas pela mecanização. Sem dúvida, apenas um processo de reforma agrária seria capaz de compensar as perdas de emprego geradas pela mecanização do corte de cana.

As metas para o fim da queima da palha de cana devem atender os interesses dos agentes envolvidos na questão, e não apenas garantir por decreto vantagens aos empresários do setor sucroenergético. $O$ autor aponta as limitações da mecanização completa em toda a área ocupada pela cultura canavieira no Estado de São Paulo, e a possibilidade de reforma agrária nas áreas não mecanizáveis como instrumento para viabilizar políticas públicas compensatórias para os cortadores de cana. Estes trabalhadores rurais terão seus empregos dizimados pela mecanização, ou suas condições de vida agravadas pelo trabalho no corte manual da cana crua, nos piores terrenos, desprezados pelas máquinas agrícolas.

Em um outro texto, o autor examina:

$\mathrm{O}$ que tem que se colocar em foco para o estabelecimento de políticas públicas compensatórias é o ritmo da mecanização que deverá se dar no mesmo ritmo da criação de novos postos de trabalho. A adequação dos ritmos entre a adoção de novas tecnologias e o estabelecimento de políticas públicas compensatórias aos empregos perdidos deve ser um dos resultados fundamentais do processo de negociação. (ALVES, 2009, p. 166)

O pesquisador apresenta a necessidade de ações que resultarão no fim da queima da cana transcender os interesses dos capitalistas do agronegócio canavieiro, que por meio da pressão política e da força econômica no Estado comprimem a direção das políticas governamentais aos seus ditames.

Alves (2009, p. 166) atenta ainda para a necessidade da criação de políticas públicas compensatórias para os cortadores de cana que perderão os 
seus empregos e não serão totalmente absorvidos com o advento total da mecanização. As ações e debates não devem centrar-se em uma iniciativa patronal (ALVES, 2009, p. 161), prescrita pelos gurus do agronegócio canavieiro, e assentado no discurso ideológico da geração de renda e riquezas ao país, discutido no início deste subcapítulo.

O autor finaliza a discussão apontando a perpetuação de uma "modernização perversa" nessas ações, "porque as novas tecnologias e de processo, ao serem implementadas, preservam e aprofundam a exploração do trabalho (ALVES,2009, p. 157). Cabe às várias instâncias e aos representantes da sociedade civil, organizar-se e impedir que as assertivas dos ideólogos do agronegócio canavieiro se tornem imperativas nas discussões que selam os rumos e as trilhas de milhares de trabalhadores rurais e de suas famílias, empobrecidos em seu município de residência, no trabalho e na passagem pelas cidades paulistas. É o que desvendaremos no subcapítulo que se segue.

\subsubsection{Os Espaços Sociais de Reprodução da Força de Trabalho Canavieira nas Cidades do Nordeste Paulista}

Os trabalhadores migrantes alocam-se, sobretudo, em residências alugadas, casas de fundo do quintal, ou pensões espalhadas pela cidade, e concentradas nos bairros periféricos das cidades. Há também alojamentos instalados em meio aos canaviais, que abrigam trabalhadores migrantes, durante a safra de cana (GEBARA, 1992; SILVA, 1999).

Segundo a coordenadora do Serviço Pastoral do Migrante em Guariba, muitos alojamentos foram desinstalados pelas usinas, e na região de abrangência da pesquisa, destaca-se apenas um deles, ocupado totalmente por trabalhadores migrantes do Vale do Jequitinhonha, no nordeste de Minas Gerais, que laboram nas plantações da gramínea moídas pela Usina Bonfim. Há, portanto, nos dias de hoje, uma concentração dos trabalhadores migrantes na sede dos principais municípios de economia fortemente vinculada à monocultura canavieira.

$O$ trabalho penoso nos talhões da gramínea negligencia do trabalhador o convívio com os demais habitantes da cidade, durante os dias da semana. A 
maioria das usinas referidas nos testemunhos orais oferece um sistema de contrato de trabalho, apoiado no descanso semanal aos domingos. Em apenas uma unidade processadora, a Central Energética Moreno, o contrato de trabalho ancora-se no sistema "cinco por um", que estabelece a folga semanal em qualquer dia da semana depois de decorridos cinco dias de trabalho. Esse sistema de trabalho foi duramente criticado nas Audiências Públicas organizadas pelo Ministério Público do Trabalho e a Delegacia Regional do Trabalho da região de Ribeirão Preto, por não permitir as práticas de sociabilidade entre os trabalhadores rurais e também no seio do núcleo familiar dos cortadores de cana já estabelecidos na cidade paulista, ou então que acompanham a migração dos trabalhadores, ao menos um dia da semana, nos domingos, com a presença e possibilidade de participação de todos.

A rotina de trabalho no eito dos canaviais inicia no alvorecer do dia, e envolve a preparação da comida que será levada no eito e o caminhar até o ponto de reunião dos trabalhadores. Os pontos de espera e os ônibus são identificados pelo nome dos turmeiros, que prestam serviços às unidades agroindustriais. Veja a Figura 21:

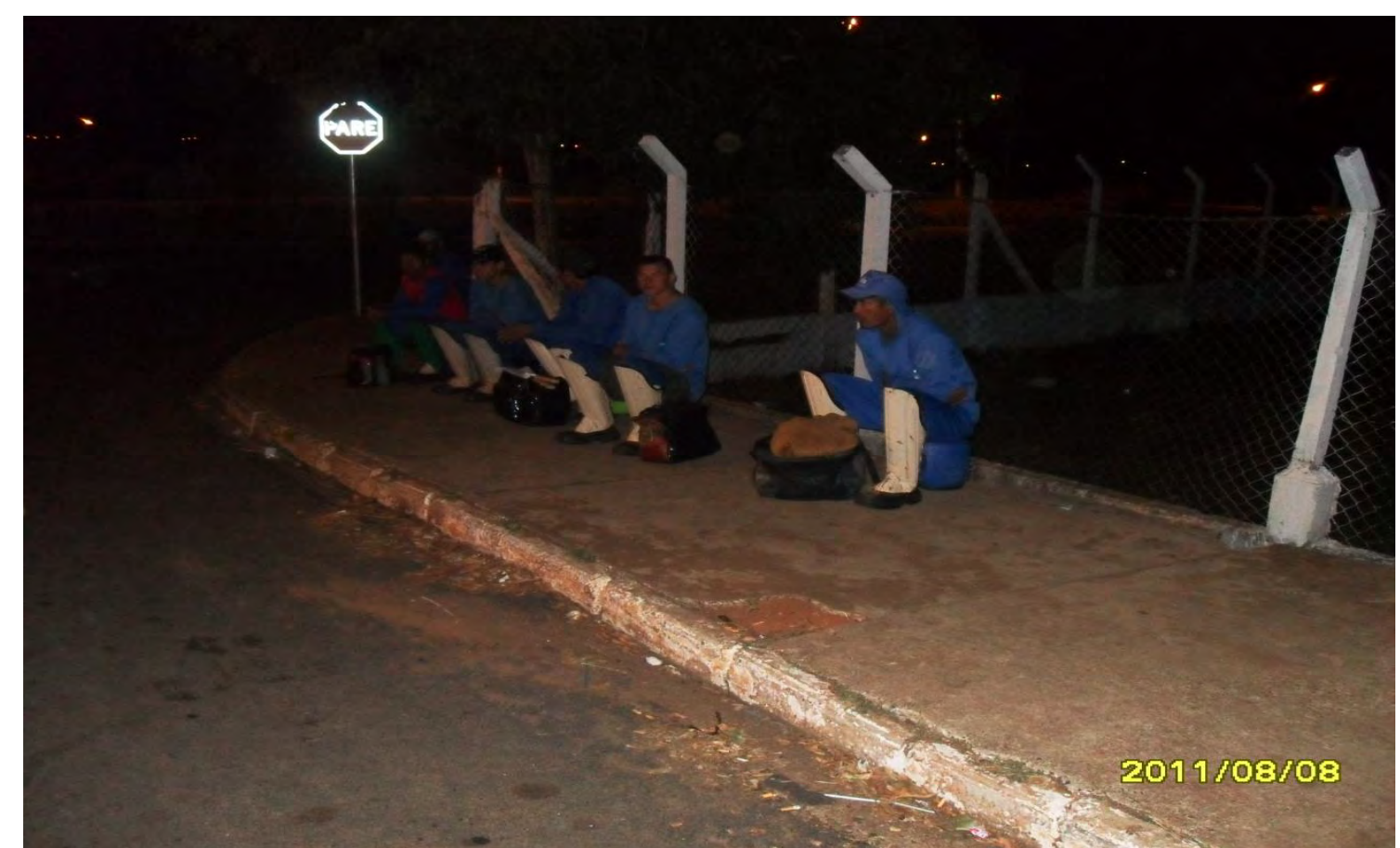

Figura 21 - Trabalho distante. Trabalhadores rurais à espera dos ônibus rurais que os conduzirão a mais um dia de labor nos canaviais e laranjais da região. Bairro Alto, Guariba/SP.

Foto do autor, 08 de agosto de 2011. 
Forma-se por volta das seis da manhã uma grande movimentação de ônibus rurais pelas ruas da cidade, cujo roteiro obedece aos pontos que congregam os trabalhadores residentes nos bairros periféricos da cidade. No interior do ônibus, homens e mulheres são conduzidos para mais uma jornada estafante de trabalho. Veja a Figura 22:

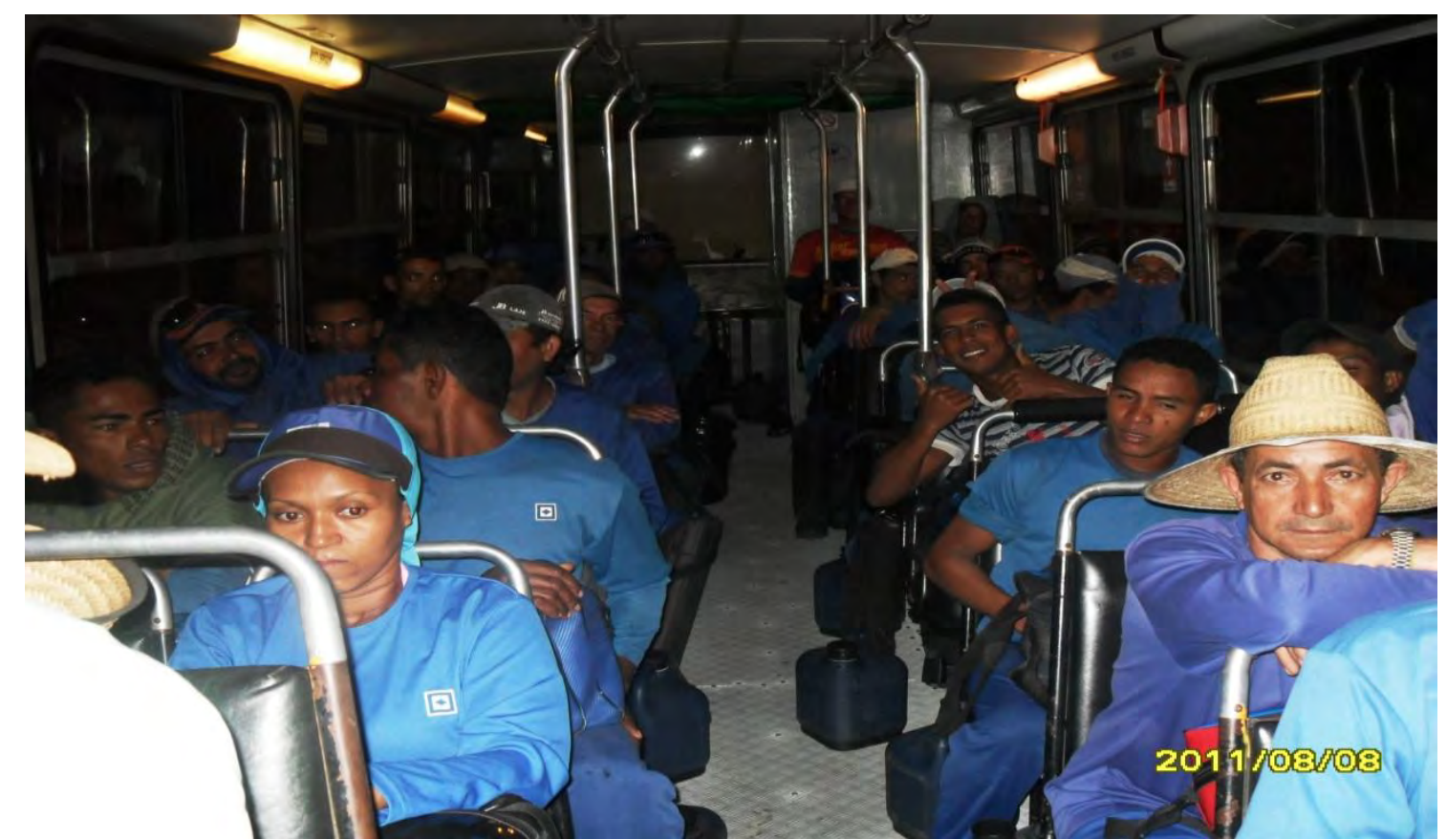

Figura 22 - Caminho para o eito. Transporte de trabalhadores canavieiros em ônibus rural, para os talhões de cana da LDC Bioenergia- unidade São Carlos. Bairro Alto, Guariba/SP.

Foto do autor, 08 de agosto de 2011.

A primeira parada no trabalho ocorre durante dez minutos, às nove da manhã para o café, e duas horas depois outra interrupção é feita para o almoço e um breve descanso que se estende durante uma hora. A terceira pausa acontece durante as duas da tarde, por dez minutos para um breve café e a última suspensão no ritmo de trabalho sucede por volta das quatro da tarde, para finalizar o serviço, anotar a produção do ganho, recolher os objetos de trabalho e partir para a casa na cidade. A sequência cotidiana no ambiente de trabalho foi registrada por meio dos testemunhos orais dos trabalhadores migrantes. Abaixo, segue o trecho da entrevista com um dos trabalhadores maranhenses: 
(...) eu acho que para mim vai ser só esse ano, eu acho que no próximo ano não venho mais para cá não, porque é sofrido demais aqui, porque a gente sofre o sofrimento da gente, a gente passa muito sono, porque todo o dia aqui nós temos que estar no ponto cinco hora da manhã, nos temos que estar no ponto, porque se a gente levanta ás vezes, faltando dez para as quatro, nós levanta para fazer a marmita, aí nós vamos para o ponto, tu vai, e o nosso ponto a gente pega bem aqui. Aí dia de chuva, rapaz! É sacrifício demais, aí quando você chega, você chega, é longe, porque as canas é longe. Tem dia que você chega aqui já são seis horas, aí a gente tem que lavar a roupa de serviço, porque a gente tem duas mudas de roupa, aí você leva uma, mas você tem que chegar e lavar aquela, que é para o outro dia, já estar no jeito. E aí eu acho muito cansativo, a gente tem muito sono, e quando dá um tempo desse, a gente, muitos não aguentam trabalhar, porque, aqui, começou a chover, muita gente diz melhorou um pouco, mas o vapor da terra sobe com aquela quenturona, que tem vez que gente que aguenta trabalhar até meio dia e de tarde já não aguenta trabalhar. (Jonas, 44, casado. Testemunho oral colhido em 24/10/2010, na cidade de Guariba/SP. Caderno de Entrevistas, p. 45)

O testemunho de Jonas revela o sofrimento da lida cotidiana do cortador de cana que levanta muito cedo para preparar a marmita para levar no eito, que tem o sono também adiado quando chega na casa e precisa realizar os serviço domésticos, como lavar a roupa que usou no trabalho, visto que é necessário ela estar enxuta no próximo dia. Jonas divide a casa alugada com outros trabalhadores maranhenses, a maioria de Codó e Timbiras. É um dos trabalhadores mais velhos da casa, e exerce uma espécie de liderança entre os moradores lá alocados. A entrevista foi realizada na tarde de um domingo, folga para a maioria dos cortadores de cana que lá residem. No seu testemunho Jonas ainda aponta a distância física dos talhões da gramínea e a demora para se deslocar dos talhões da gramínea até a casa na ligada, já no anoitecer. O calor é estafante, mesmo depois da chuva, onde as altas temperaturas e o cansaço convidam o corpo a diminuir o ritmo e a parar de trabalhar, mas a imposição das exigências do labor insiste em Ihe castigar.

Já outros trabalhadores contam com o apoio de integrantes da família, como Odair que vive com dois filhos jovens. Odair estabeleceu-se em Guariba 
desde 2003, e desde então até o encontro com o entrevistado em Codó, havia realizado oito safras completas. Ele descreve da seguinte maneira a sua rotina cotidiana para o trabalho:

Minha organização, minha filha me ajuda. Quatro e dez eu levanto. Ela não sai da cama dela também. Ela estuda pela manhã. Ela faz janta. Me ajuda. Agora, eu levanto cedo, venho na geladeira. Se tem comida, já é só aprontar. Saio para o ponto às cinco horas. Eu pego aqui pertinho também, entendeu? Chega lá bate um ranguinho cedo, nove horas, tem uns dez minutos de, nós temos, não? Nove horas parou. Volta às onze horas, fica uma hora, almoça, depois meio dia volta para o serviço, duas horas, tem mais dez minutos, e depois três e vinte, o horário de cartão, que é tudo no cartãozinho, assim. Você passa as sete horas e depois passa as onze, não é? Passa meio dia para voltar e depois passa as três para vir embora. (Odair, 37, separado. Testemunho oral colhido em 24/ 10/2010 na cidade de Guariba/SP. Caderno de Entrevistas, p. 46)

No registro oral de Odair notamos a participação da filha, contribuindo para a realização dos serviços domésticos, em especial no preparo dos alimentos. $\mathrm{O}$ entrevistado descreve a rotina de trabalho, dando realce aos momentos de interrupção para alimentar-se e ter um rápido descanso, momentos que são operacionalizados e controlados por um cartão de registro das paradas. O tempo de trabalho é o que predomina, e em uma atividade onde o ganho é por produção, faz-se o controle dos comportamentos e das necessidades físicas dos corpos maximizando-se o período de produção.

A rotina insuportável do cotidiano dos trabalhadores nos canaviais paulistas também é reproduzida por aqueles que permanecem no Maranhão. Nas palavras de uma entrevistada:

Eu ficava só com pena assim quando eu falava com ele e ele dizia assim: ei mulher mas eu tô sofrendo demais. Aquilo ali doía por dentro não é, ele dizia aquilo mulher eu to sofrendo demais aqui no São Paulo, ele dizia: esse serviço aqui é um serviço pesado, não é? Muitas vezes ele dizia assim: olha eu cheguei agorinha do serviço e ainda vou fazer de comer, eu ficava assim com pena muitas vezes até terminava eu chorando aqui não é, ele dizia : mulher você está chorando, eu digo: não ele disse está sim. Eu fico com pena assim de ver ele sofrendo mas o que tem que fazer 
não é?. (Francisca, 42, casada). Testemunho oral colhido em 16/01/2011, na cidade de Timbiras/MA. Caderno de Entrevistas, p. 82

A experiência de pobreza que acompanha a vida das famílias de trabalhadores migrantes intensifica com o sofrimento e a ausência prolongada de integrantes, que foram obrigados, pelas necessidades e dificuldades na região de origem a migrar para longe, a sujeitar-se a um serviço pesado.

A precariedade das condições de trabalho também se estende para a casa onde residem nas cidades paulistas. $\mathrm{O}$ alto preço pago pelo aluguel e as tarifas de água e energia consomem os parcos rendimentos, que também precisam ser poupados e/ou enviados aos integrantes da família que ficaram no município do leste maranhense. De acordo com Antônio:

Vou dizer assim. A coisa mais ruim lá, é o aluguel que a gente paga que ainda é muito caro. É um absurdo. $O$ aluguel mata a gente viu? Se não pagasse o aluguel lá. Oh lugarzinho bom para ganhar dinheiro!

(Francisco, 25, casado. Testemunho oral colhido em Timbiras/MA, em 19/01/2011. Caderno de Entrevistas, p. 138).

As dificuldades em pagar o aluguel comprimem o ganho dos trabalhadores migrantes, e as despesas com outras necessidades básicas dos trabalhadores como a alimentação. Todavia, a economia com a compra de alimentos pode ser compensado por produtos e alimentos originários da produção familiar na unidade camponesa, trazidos na viagem para o interior paulista, ou remetido pela família no Maranhão, por meio dos deslocamentos sazonais dos ônibus clandestinos, questão que será tratada com maior profundidade no próximo capítulo.

A precariedade, contudo não se restringe ao pagamento do aluguel e da conta de energia. A superlotação de muitas casas alugadas, reunindo muitas vezes pessoas de uma localidade de origem, ou do mesmo grupo familiar e de amigos mostram as estratégias usadas para minimizar os custos econômicos e também psicológicos do processo migratório. A precariedade das instalações e dos equipamentos na residência revela a transitoriedade, mas também a pobreza 
Vettorassi (2006, p. 23 -24) ao investigar a importância da cafeicultura para a economia do recém-criado município indica que no período entre 1918 e 1929 esta se fazia dominante, importância que decresce significativamente após a Grande Depressão, na qual a desagregação do núcleo social nas fazendas de café, com a diminuição da população rural e a reestruturação espacial da cidade e do campo. Nesse período ainda a dinâmica social, econômica, política e cultural, é ainda comandada pela cafeicultura. Na Figura26, observe o núcleo urbano delimitado pelos trilhos da ferrovia.

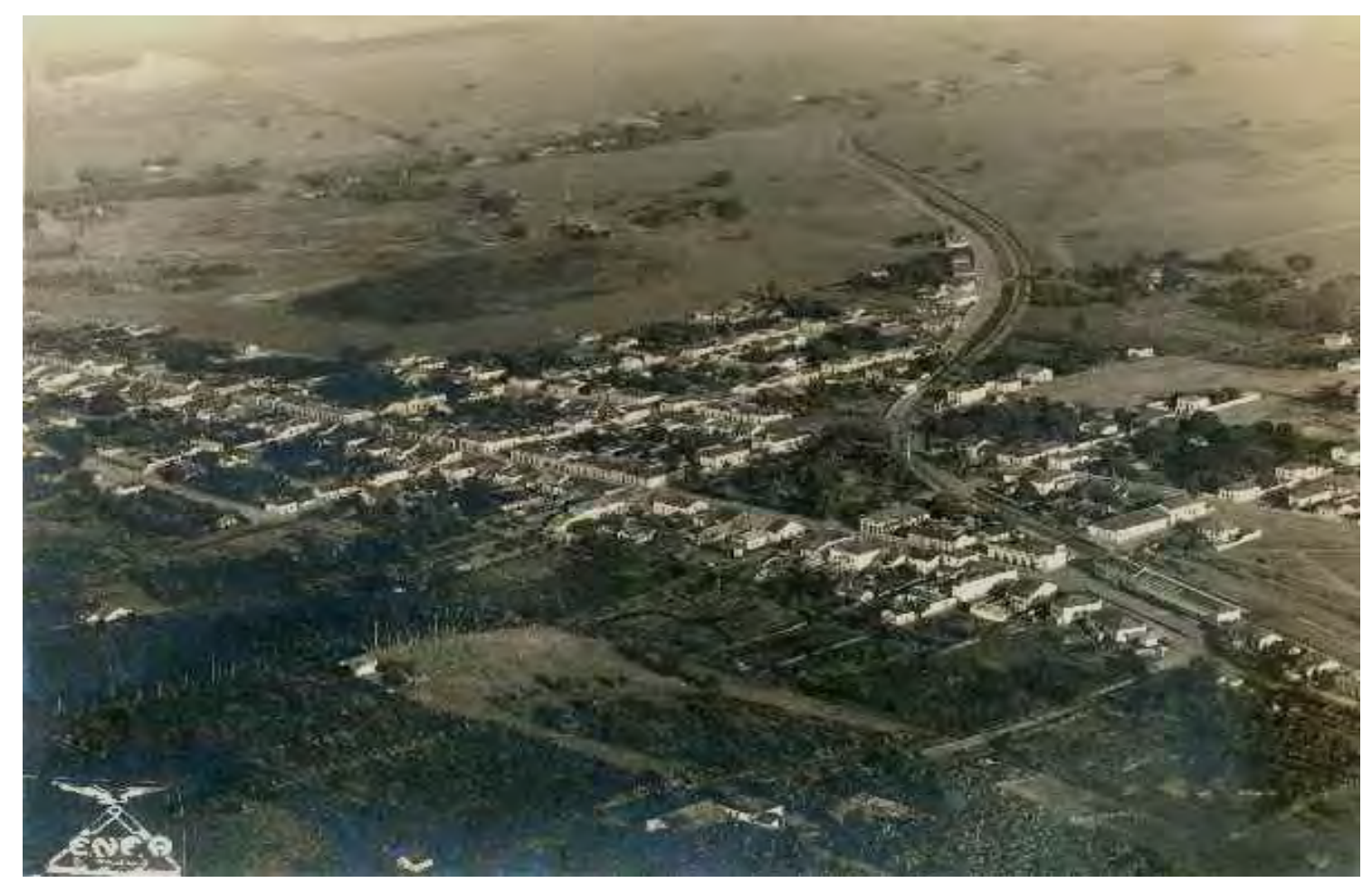

Figura 26 - Guariba do café. Vista do núcleo urbano de Guariba/SP.

Fonte: Acervo de Fotografias Aéreas Oblíquas de 1939/1940 do Instituto Geográfico e Cartográfico do Estado de São Paulo.

A venda das propriedades, sob a forma de pequenos lotes de terra a excolonos, permitiu o desenvolvimento de vários cultivos agrícolas, como o algodão e a cana-de-açúcar, esta última destinada, à produção, sobretudo, em pequena escala, de aguardente.

A conjuntura econômica internacional favorável ao mercado do açúcar nos anos trinta e quarenta, a criação das usinas São Martinho e Bonfim em 1948, bem como a adoção de políticas severas de erradicação da cultura cafeeira 
possibilitaram ao município de Guariba assentar gradativamente a sua economia na atividade canavieira.

Nesse momento Guariba, experimentava transformações estruturais que estavam em curso em diversos municípios paulistas, que tinham sua vida econômica, política e sociais fortemente dependentes da cafeicultura. Silva (1999, p. 220 - 222) referiu-se a este momento como a passagem da "civilização cafeeira" para a "civilização da usina", na qual todo o universo cultural e a divisão social do trabalho ancoradas na complementaridade entre cidade e campo e na constituição de áreas rurais densamente povoadas foi desestruturada por um processo homogeneizador que produziu uma reestruturação espacial do campo e da cidade.

A mudança da maneira de produzir no campo, com a consequente perda da importância da economia do excedente nas fazendas de café, gerou um aprofundamento da divisão social e territorial do trabalho, despovoando as áreas rurais e produzindo uma forte migração rural-urbana. Com ela "uma nova leitura do espaço" nas antigas cidades da civilização cafeeira se processou convertendo parte de seu perímetro urbano, em bairros periféricos que iriam alocar ex-colonos e outros agentes sociais integrados ás áreas produtoras da rubiácea. A passagem da civilização cafeeira para a civilização da usina, portanto significou a formação de bairros na periferia no núcleo urbano de diversos municípios do nordeste paulista.

Na cidade de Guariba, ainda na década de 1950, foi criado um loteamento, próximo ao acesso a sede do município, por Guido Garavello, empreiteiro e proprietário local, que deu origem ao Bairro Alto, conhecido popularmente como João de Barro.

Este bairro representou segundo Vettorassi (2006, p. 27) o primeiro espraiamento do perímetro urbano da cidade do café, e teve como primeiros residentes os migrantes nordestinos que foram atraídos para as atividades da lavoura canavieira na região.

A autora ancorada em Mendes (1997, p. 143) coloca que a iniciativa do loteamento, por meio da venda de terrenos a um custo, e em várias parcelas era evitar a desvalorização imobiliária da Vila Garavello, loteamento vizinho, 
construído pelo mesmo empreiteiro, próximo do bairro, por moradores nordestinos.

Nas duas décadas seguintes, novos bairros na periferia urbana foram erigidos, como o Jardim Monte Alegre, que juntamente com o Bairro Alto passaram a alocar, sobretudo migrantes, sitiantes e parceiros que foram expropriados na região em razão da expansão canavieira. De acordo com Baeninger (2009) Guariba, juntamente com o município de Sertãozinho apresentaram uma taxa de crescimento demográfico superior a $5 \%$, as maiores da região administrativa de Ribeirão Preto, cuja média encontrava-se em torno de 2,14\% ao ano na década de 1970.

Os anos 1980 marcam a produção do terceiro cinturão urbano em Guariba, produto da expansão da economia sucroalcooleira regional motivada pelo Proálcool (Programa Nacional do Álcool), dando origem a uma vila operária, um conjunto habitacional de médio padrão e um loteamento de alto padrão (VETTORASSI, 2006). Verifica-se aí o esboço de uma segmentação sócioterritorial no núcleo urbano e da (re)criação de estigmas sociais entre os considerados "nativos" e os "de fora", que Vettorassi descortina em seu trabalho.

Por meio da configuração territorial desses cinturões periféricos, podemos questionar o conceito de cidade-dormitório, que produz um olhar homogeneizador do núcleo urbano, relacionando-o diretamente a uma atividade produtiva e convertendo todos os seus habitantes em força de trabalho, camuflando as desigualdades sociais, econômicas e as representações culturais e simbólicas multifacetadas que se territorializam na cidade.

Como pudemos verificar, a organização do bairro Alto aponta para a construção de distintas e afastadas territorialidades no interior da cidade: uma territorialidade construída, sobretudo, por trabalhadores rurais, migrantes, locais, que se ocupam na lavoura canavieira e de outras culturas agrícolas na região, e uma outra organizada em torno daqueles que se consideram "do local", apoiada nas reminiscências da Guariba das fazendas de café, das primeiras décadas do século $X X$.

Dancini (1989, p. 154) assim expõe:

O João de Barro é um dos momentos de operacionalização da geógrafia da dominação. Mas é, também, um dos lugares em que se arrancha um dos rostos do contra-ponto, lugar de 
desterro forçado, transmutado em reduto pelos homens, mulheres e crianças ali acuados. (DANCINI, 1989, p. 154)

São nos bairros da periferia urbana que residem os trabalhadores canavieiros, sobretudo os migrantes, que laboram em diversas usinas sediadas nos municípios da região. Neles também encontramos a moradia de trabalhadores rurais que há muito tempo instaram na cidade de Guariba, seja com a família que deixou seus locais em seus Estados de origem, seja com aqueles que já moravam na cidade paulista.

Vindos dos Estados da Bahia, Ceará, Alagoas, Pernambuco, Paraná, e principalmente do nordeste de Minas Gerais, os trabalhadores migrantes na agricultura canavieira, tornaram-se expressivos, e já na década de 1980 representavam a maior parte dos trabalhadores rurais canavieiros, que se ocupavam em diferentes atividades agrícolas da gramínea: plantio, tratos culturais, aplicação de veneno, bituca, e principalmente o corte de cana. Homens, mulheres, jovens, idosos, casados, solteiros, brancos, pardos e negros.

Instalavam-se em casas de fundo de quintal, em pensões ou alojamentos comandados por "gatos" ou por representantes da usina, localizados na cidade ou no meio rural, em meio aos canaviais. Nas cidades em que se aloja no interior paulista, a moradia provisória ou permanentemente provisória do migrante sazonal guardava um sentido totalmente distinto da região de origem.

Gebara (1992, p. 21) aponta que o significado do morar, por mais modestas que sejam as casas dos migrantes do Vale do Jequitinhonha, significa participar da vida comunitária, diferente das representações que guardam das regiões de destino, associado ao lugar de descanso da labuta cotidiana. O morar, nas regiões de destino de camponeses migrantes envolve além da casa de morada, outros espaços sociais, que integram a territorialidade camponesa, como o quintal e o roçado, visto que parcelas expressivas dos mineiros como eram e são designados os trabalhadores rurais, originários, sobretudo da região do Médio Jequitinhonha, no nordeste de Minas Gerais, nas áreas de destino migram para atender as necessidades da unidade familiar camponesa, em seus locais de origem.

As cidades dos "boia- frias "foram também aquelas que apresentaram o mais forte crescimento demográfico entre os núcleos urbanos da região agrícola 
de Ribeirão Preto, como pudemos verificar nos casos de Pradópolis e Guariba. No que reporta ao último município, observe a Tabela 17:

Tabela 17 - Guariba/SP: População Total, Rural e Urbana (1970 - 2010).

\begin{tabular}{|c|c|c|c|c|c|}
\hline \multirow{2}{*}{$\begin{array}{c}\text { Censo } \\
\text { Demográfico }\end{array}$} & $\begin{array}{c}\text { População } \\
\text { Total } \\
\text { (em habitantes) }\end{array}$ & \multicolumn{2}{|c|}{ População Urbana } & \multicolumn{2}{|c|}{ População Rural } \\
\cline { 3 - 6 } & Absoluta & $\begin{array}{c}\text { Em habitantes) } \\
\%\end{array}$ & $\begin{array}{c}\text { Absoluta } \\
\text { (em habitantes) }\end{array}$ & Em \% \\
\hline 1970 & 11.448 & 9.144 & 79,87 & 2.304 & 20,13 \\
\hline 1980 & 18.893 & 16.234 & 85,93 & 2.659 & 14,07 \\
\hline 1991 & 28.911 & 27.615 & 95,52 & 1.296 & 4,48 \\
\hline 2000 & 31.085 & 30.223 & 97,23 & 862 & 2,77 \\
\hline 2010 & 35.491 & 34.753 & 97,92 & 738 & 2,08 \\
\hline
\end{tabular}

Fonte: Censo Demográfico de 1970, 1980,1991, 2000 e 2010.

Cidades estas, que de acordo com Silva (1993, p. 30) reuniam simultaneamente os locais de reprodução da força de trabalho, os locais de realização do mercado de trabalho, e se convertiam em locais controlados socialmente pelo poder da usina ou da grande fazenda, de forma direta ou indireta, além de abrigar espaços sociais diferenciados a partir da estrutura de classe e das diferenças entre os sexos. Cidades, enfim, que conforme apontado anteriormente, e que de acordo com a autora:

não podem ser consideradas cidades-dormitórios de bóiasfrias, uma vez que esta denominação encobre as diferenças sociais que lhe subjazem e que são responsáveis também pela reprodução de relações de dominação sobre esses trabalhadores.(SILVA, 1993, p.30)

Territorialidades conflitantes e combinadas que marcam o processo de produção do urbano na cidade de Guariba.

A década de 1980, em particular, foi sacudida por inúmeras manifestações grevistas, em parte geradas pelo contexto do movimento sindical brasileiro que vivenciava desde as greves dos metalúrgicos do $A B C$, no final da década de 1970, à possibilidade de um "novo sindicalismo", diferente do modelo proposto e 
controlado pelo Estado durante o golpe militar, bem como às lutas dos movimentos sociais pela redemocratização do país.

No movimento sindical dos trabalhadores rurais, dentre os quais figura o trabalhador canavieiro, significava romper com o modelo da Contag, ancorado em um sindicalismo assistencial e em obediência à Lei de Greve imposta pelo golpe militar (THOMAZ JR., 2002, p.298), arrefecendo as agitações políticas levadas a cabo pelos trabalhadores rurais em meados das décadas de 1950 e 1960.

O movimento de Guariba em maio de 1984, significou não apenas a luta pela conquista de direitos trabalhistas, mas a possibilidade de expor a dura vida e a dura lida de homens, mulheres e famílias abreviados na sua condição humana, que experimentaram de forma penosa a negação até o de se recomporem suas energias vitais para o açoite nos canaviais. Nesse ínterim, Dancine (1989, p. 163):

Na greve de 1984, por exemplo, o trabalhador veste ao mesmo tempo a condição de cidadão. $O$ não às sete ruas $e$ o fogo nos canaviais, vem colado ao fogo a SABESP. Tornam visíveis a insuficiência do ganho, a degradação da sua condição rural. Deixam claro que não basta ser trabalhador, honesto, direito, um sujeito que leva as contas em dia, que resiste ao suborno do feitor, que recusa a condição de olheiro do "outro", para ter direito à sobrevivência. É aí que se mostra mais deslavada a distância entre 0 ganho e 0 custo de vida na cidade. (DANCINI, 1989, p. 163)

A constituição do sindicato dos trabalhadores rurais no município foi produto dos desdobramentos do Movimento de Guariba. Veja a sede do Sindicato dos Empregados Rurais Assalariados de Guariba, na Figura 27: 


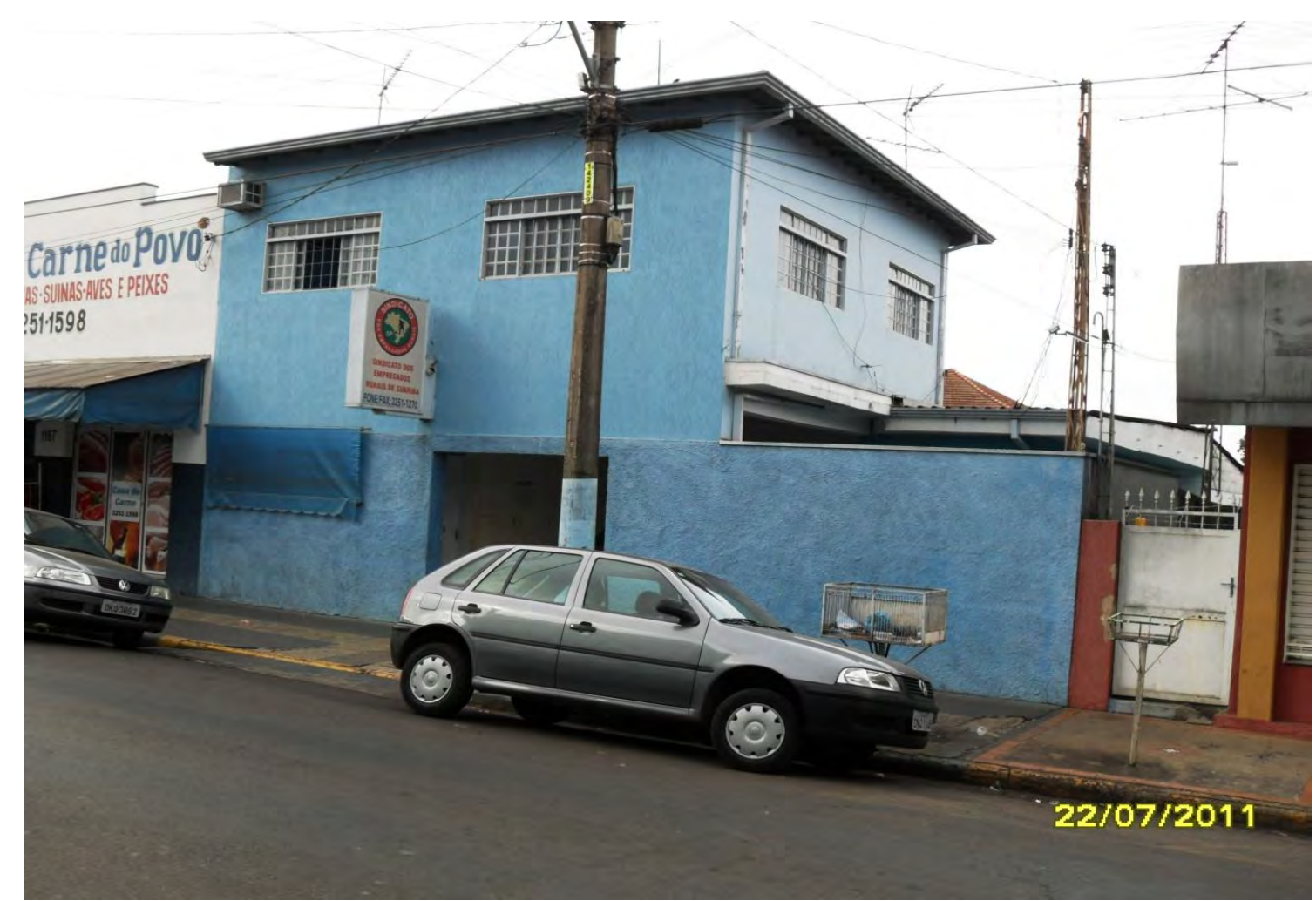

Figura 27 - Sindicato no centro. Fachada do Sindicato dos Empregados Rurais Assalariados de Guariba, no centro da cidade.

Foto do autor, 22 de Julho de 2011.

Núcleos urbanos que também constroem diversas e distintas territorialidades migratórias, materializadas em seu espaço urbano ao longo do tempo. Territorialidades migratórias cindidas, como no caso dos bairros que concentram trabalhadores migrantes na periferia urbana de Pradópolis e Guariba, e que passaram a abrigar uma quantidade expressiva de migrantes vindos principalmente dos Estados do Maranhão e Piauí, durante os anos 2000.

A designação local conferida aos trabalhadores migrantes nas cidades do interior paulistas os reduz a condição de habitantes dos seus Estados de origem, sem variação de gênero e grau: são conhecidos como maranhenses, assim como se referiam e se referem aos mineiros do Vale do Jequitinhonha.

No que diz respeito à região de origem desses trabalhadores migrantes, a maioria deles são procedentes do Maranhão, Alagoas e Paraíba, além dos oriundos do nordeste de Minas Gerais. Trata-se de uma mudança que vem ocorrendo em vários municípios produtores de cana-de-açúcar no Estado de São Paulo, e que Silva (2008, p. 100) designa como mudança da cartografia migratória: (SILVA, 2008, p. 100), expressa por meio da Tabela 18: 
Tabela 18 - Número estimado de trabalhadores migrantes do Estado do Maranhão e do Piauí para o Estado de São Paulo.

\begin{tabular}{|c|c|c|}
\hline Safras & $\begin{array}{c}\text { Número estimado de trabalhadores migrantes do } \\
\text { MA e PI para S. Paulo }\end{array}$ & Diferença \\
\hline $2000 / 2001$ & 100 & ---- \\
\hline $2001 / 2002$ & 300 & +200 \\
\hline $2002 / 2003$ & 1.000 & +700 \\
\hline $2003 / 2004$ & 3.000 & +2.000 \\
\hline $2004 / 2005$ & 5.000 & +2.000 \\
\hline $2005 / 2006$ & 6.000 & +1.000 \\
\hline
\end{tabular}

Fonte: Pastoral do Migrante (2005) apud Silva (2006, p. 116).

A presença de cortadores de cana, em sua maioria migrantes, entre os meses de maio a dezembro, assumia novas proporções, afetando as relações cotidianas até então estabelecidas no interior da cidade.

Essa foi uma das preocupações de Vettorassi (2006) ao constatar o descompasso entre a ideologia de cidade violenta atribuída a Guariba em razão da elevação dos índices de criminalidade atribuídos a trabalhadores migrantes durante o corte de cana. Ideia enganosa, conforme constata a autora, sustentada por meio de uma criminalização impingida sobre os volantes migrantes pelos "nativos", ou seja, pelos moradores mais antigos, de descendência europeia e residentes nos bairros centrais da cidade.

Acerca do controle exercido, por meio dos códigos de conduta e honra, enraizados no interior da unidade camponesa, nas áreas de migração Menezes (2002, p. 161), assim coloca:

Pensamos em comunidade de origem, em conformidade com o sentido conferido por Menezes (2002, p. 161) em sua investigação sobre os roteiros migratórios de camponeses migrantes do Agreste paraibano para o trabalho sazonal na área canavieira da Mata Norte pernambucana. De acordo com a autora:

O senso de comunidade também se expressa na forma como os migrantes interpretam a convivência dentro dos alojamentos. Consideram-se "irmãos", estendendo a noção de parentesco para abranger irmãos, primos e tios fictícios. 
A noção de irmandade, como uma referencia identitária, estimula os migrantes a formar coalizões entre pessoas do lugar de origem, e estabelecer diferenças com outros grupos.

Novas amizades maranhenses, que não se firmaram em Timbiras, mas no interior paulista, e são importantes elos de sociabilidade entre esposas de trabalhadores maranhenses, que ficam confinadas no espaço da casa, cuidando dos maridos e filhos, como podemos observar por meio do testemunho abaixo:

Pesquisador: E lá Edna, você, também, de uma certa forma também você fica lá. Tem outras colegas que são daqui e foram com o marido, ou você...

Edna: Não. Até que eu não conheci daqui não, eu fiz amizade mais, depois que eu estava lá. São as de lá mesmo. Assim, do Maranhão, mas eu conheci lá e não aqui. Não levei as minhas amizades daqui de Timbiras. Eu conheci lá.

(Edna, 23, casada. Testemunho oral colhido em Timbiras/MA, em 19/01/2011. Caderno de Entrevistas, p. 133).

Novas amizades maranhenses, que não se firmaram em Timbiras, mas no interior paulista, e são importantes elos de sociabilidade entre esposas de trabalhadores maranhenses, que ficam confinadas no espaço da casa, cuidando dos maridos e filhos, como podemos observar por meio do testemunho abaixo:

Pesquisador: E lá Edna, você, também, de uma certa forma também você fica lá. Tem outras colegas que são daqui e foram com o marido, ou você...

Edna: Não. Até que eu não conheci daqui não, eu fiz amizade mais, depois que eu estava lá. São as de lá mesmo. Assim, do Maranhão, mas eu conheci lá e não aqui. Não levei as minhas amizades daqui de Timbiras. Eu conheci lá.

(Edna, 23, casada. Testemunho oral colhido em Timbiras/MA, em 19/01/2011. Caderno de Entrevistas, p. 133).

Entre os anos de 2005, 2006 e 2007, na cidade de Guariba, migrantes maranhenses atuaram na organização da festa do Boi, com o apoio da Pastoral 
do Migrante. A festa foi incluída na programação anual da secretaria municipal de Cultura e contou com ampla participação dos guaribenses. Observe a Figura 28:

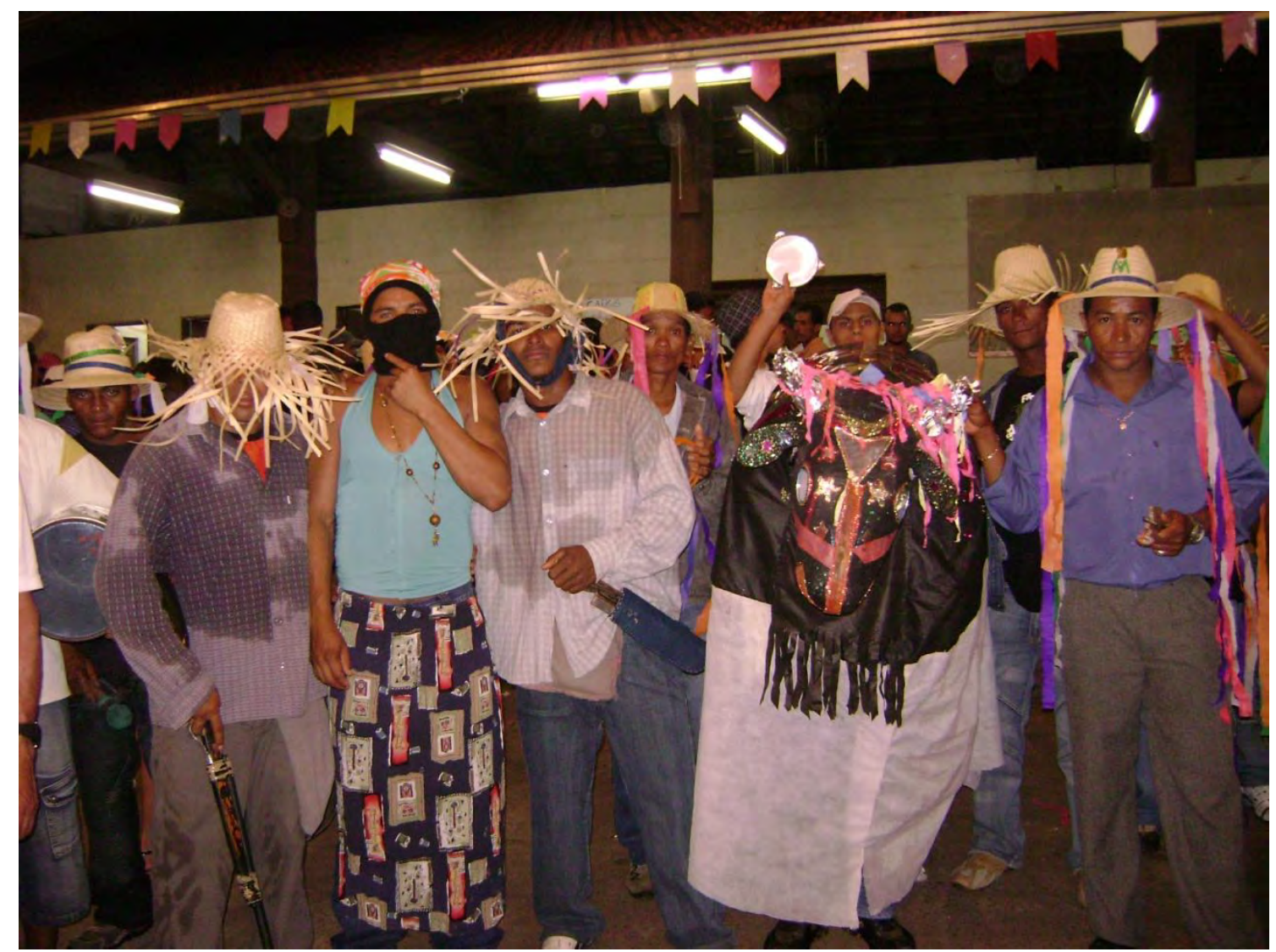

Figura 28 - Bumba meu boi maranhense em Guariba. Trabalhadores rurais reproduzem a festa do Bumba meu Boi, em Guariba/SP, em 2008.

Foto cedida pelo Serviço Pastoral do Migrante. Pesquisa de campo em 22 de Julho de 2011.

A distância da terra natal e a permanência insistente em um destino favorece a recriação material de esferas da vida, que mesmo com a ausência dos familiares, amigos e o meio físico de Timbiras, e do Maranhão, fortalecem uma territorialidade, migratória para os que sonham com o "retorno", híbrida, porque já não serão mais os mesmos. 


\section{IDAS E VINDAS: REDE DE RELAÇÕES PESSOAIS NA CONSTRUÇÃO DE TERRITORIALIDADES MIGRATÓRIAS}

\subsection{Redes de informações que sustentam o processo migratório de famílias de trabalhadores rurais maranhenses para o labor nos canaviais paulistas}

Os deslocamentos de homens, mulheres, famílias inteiras originárias do município de Timbiras/MA para o labor nas atividades da agricultura canavieira no Estado de São Paulo se desenrola por uma série de redes de relações pessoais, que abrange diversos agentes sociais, tanto no Maranhão, no município timbirense e também em municípios vizinhos, como nas cidades que os abrigam no nordeste do Estado de São Paulo, Guariba e Pradópolis.

Essas redes de relações pessoais fundamentais para alavancar a experiência migratória se costuram, se refiguram e se fortalecem a partir de múltiplas formas de trocas de informações entre os que migraram, os que não migraram e entre os possíveis migrantes e os agentes responsáveis pelo processo de deslocamento e recrutamento até a área canavieira paulista. Embora experimentada de forma distinta, entre os agentes supracitados, as informações acerca do local e das condições de trabalho e da residência na cidade do interior paulista, são essenciais na organização dos itinerários migratórios, principalmente daqueles que ingressam neste processo social.

No entanto, as informações que sustentam tanto no plano material como simbólico, as experiências e expectativas quanto ao processo migratório, carecem de confiabilidade e de legitimidade, de certa maneira para contrabalançar os custos econômicos e psicológicos da(s) experiência(s) migratória(s).

Nesse contexto, cresce a importância da troca de informações obtidas a partir dos que migraram e que são próximos no interior do núcleo familiar, ou em um conjunto mais amplo de relações sociais que abrangem parentes, vizinhos, amigos e compadres que já passaram ou que experimentam a migração para o labor nos canaviais paulistas. Essa troca de informações é importante também para aqueles que irão se deslocar para o interior paulista, na próxima safra da 
gramínea, depois de um relativo período distante do trabalho nos talhões de canade-açúcar, a partir da residência nos referidos municípios paulistas.

A importância dessas informações, obtidas por meio de redes de relações primárias sustentadas a partir do município de Timbiras foi registrado na fala de um trabalhador rural maranhense:

Rapaz, eu já tinha um amigo aqui já. Ele já tinha trabalhado aqui. Desde 2002 ele vinha para cá. Quando ele chegava lá ele me convidava: você está indo, vamos lá! ,E aí eu dizia para ele assim: rapaz, eu não vou não, porque eu sei, porque eu posso não passar no exame. A usina aí pega esse dinheiro aqui, eu vou gastar duzentos e cinquenta reais para eu ir, aí eu chego lá, eu não passo nos exames, aí eu vou ter que trabalhar no roço lá um dia para eu poder voltar. Isso nada, rapaz! Vai passar tranquilo e disse: tu vai que eu ajeito serviço para ti lá, porque ele já era acostumado. Aí, tu vai dar certeza, que eu vou na frente e ajeito o serviço para ti. E digo: vou! Aí ele veio na frente, aí eu dei um número de um telefone lá de um vizinho meu, aí quando ele ligou, ele está ali fora, para mim dizendo que era para eu vir que o serviço, ele já tinha falado com o turmeiro e já estava, era para eu vir, não demorar não que eles iam me fichar. Aí eu já estava com o dinheiro pronto, aí ele chegou. O dia que eles saem lá é, como eu lhe falei, é dia de sextafeira, e aí chegou o dia de sexta-feira eu peguei o ônibus, e nós viemos em oito de lá de pertinho, aí quando a gente chegou aqui ele já tinha ajeitado um barraco para nós. Nós chegamos aqui no dia de domingo, assim umas sete e meia do dia, aí ele já tinha ajeitado um barraco para nós, só que não tinha era cama: viu, só a minha, por hoje a gente vai depois ajeitando as camas aí para vocês. (...) Aí a gente fez os exames, aí nós passamos todo mundo, e aí quando nós fomos saber o resultado nós oito que viemos de lá passou todo mundo, e aí ele falou assim, disse: olhe menino, depois de amanhã, nós vamos pegar os material. Aí no dia certo que ele falou, a gente foi e pegou o material e aí já no outro dia a gente já começou a trabalhar. (Antonio, 44, casado. Testemunho oral colhido em Guariba/SP, em 24/10/2010. Caderno de Entrevistas. P. 30-31).

O registro oral acima do trabalhador rural maranhense indica a importância de seu amigo para o início do deslocamento do entrevistado para o trabalho nos canaviais do Estado de São Paulo. Nos períodos em que estava em Timbiras, 
estimulava o trabalhador rural a migrar, retornando anteriormente a Guariba, indo na frente e ajeitando o serviço para o amigo.

O temor do trabalhador rural maranhense não passar no exame reflete as expectativas em torno das médias de produtividade diária requeridas pela usina e grandes plantadores de cana aos trabalhadores canavieiros durante a colheita da gramínea. Demonstra também, de certo modo, as preocupações do entrevistado com a perda do dinheiro da passagem, e daí a fragilidade dos recursos monetários e do calculo arriscado das despesas com a migração, obtidos a partir da economia camponesa, e as incertezas do trabalho do entrevistado em uma atividade especializada e extremamente seletiva, no que tange à escolha etária de trabalhadores com possibilidades de maiores ganhos de produtividade nos talhões de cana-de-açúcar.

O apoio do amigo não se restringiu à busca de serviço para o migrante maranhense, mas também no fato de ter ajeitado um barraco para nós, ou seja, um grupo de trabalhadores - nós viemos em oito de lá de pertinho - que se deslocara para a realização da safra canavieira no nordeste paulista. Informações de confiança obtidas a partir de uma rede de relações primárias, assentadas no local de destino, amenizam os dramas econômicos e subjetivos da migração, principalmente para aqueles que passam pela primeira experiência migratória, ou pelo primeiro ensaio de deslocamento para o trabalho nas plantações de cana-deaçúcar, no interior paulista.

O compartilhamento de informações, fundamentais para a concretização da experiência migratória e de suas representações assenta-se em relações recíprocas, das quais emaranham fortes redes de relações sociais, que garantem - acesso a múltiplas oportunidades, possibilitando a construção de territorialidades migratórias nos locais de destino, que independe da proximidade física dos indivíduos no tempo e no espaço.

De acordo com o historiador italiano Franco Ramella (1995, p. 19):

Os pesquisadores que utilizaram o enfoque da rede demonstraram a importância fundamental do estudo analítico para compreender os processos sociais através dos quais a informação passa e se difunde. No tema que discutimos, são estes processos sociais - e não o encontro abstrato entre demanda e oferta - os que influem 
diretamente por uma relação entre demanda e oferta - os que influem diretamente por uma parte, a natureza e a composição da emigração, e por outro, a colocação dos emigrados no mercado de trabalho dos países receptores, isto é, suas posições e recompensas ${ }^{33}$.

Com isso Ramella (1995, p. 19) revela a importância das informações de confiança, nutridas a partir de fortes relações de reciprocidade, sustentadas mesmo com a distância física dos agentes sociais, para o acesso a várias oportunidades que se materializam nos locais de destino, e que alicerçam simbolicamente a migração e o incentivo a novas experiências migratórias.

O acesso a informações dotadas de certa confiabilidade podem unir agentes sociais distantes espacialmente, e não reunir grupos que compartilham o mesmo lugar de morada familiar. Nos deslocamentos migratórios para a área canavieira paulista, isso pode representar uma relativa economia e uma vitória simbólica acerca da migração para o trabalho na safra canavieira paulista, ou a enganação pela "conversa bonita" do gato, do emprego em usinas ou plantadores de cana que atrasam o pagamento de salários e os submetem a residir de forma aviltante nas periferias das cidades do interior paulista, etc.

Por isso, essas informações valiosas não se estendem a todos os trabalhadores de Timbiras, residentes em Pradópolis, Guariba, e noutras sedes de importantes municípios canavieiros do Estado de São Paulo.

Ainda, conforme Ramella (1995, p. 20):

(...) A informação não é, portanto, a mesma para todos os vizinhos ou conterrâneos do povo, nem necessariamente se transmite de vizinho a vizinho, porque os canais através dos quais passa são as relações sociais fortes que prescindem da distância e por fim a frequência dos contatos. (...) Em

\footnotetext{
${ }^{33}$ Los investigadores que han utilizado el enfoque de la rede han demostrado la importancia fundamental del estudio analítico para comprender los procesos sociales a través de los cuales la información pasa y se difunde. En el tema que nos ocupa, son estos procesos sociales - y no el encuentro abstracto entre demanda y oferta - los que influyen directamente por uma tracto entre demanda y oferta - los que influem directamente por uma parte, la naturaleza y la composición de la emigración, y por outra, la colocación de los emigrados em el mercado de trabajo de los países receptores, es decir, sus posiciones y recompensas.(...).
} 
resumo: na mesma comunidade de procedência, sobre a base da concreta articulação das redes de relações dos indivíduos, existe o que tem informação e o que se encontra desprovido dela, o que tem certas informações e o que tem outras $^{34}$.

Não há, portanto, a conformação de redes de relações primárias nos locais de destino, que sustentam de forma unívoca as migrações a partir de um determinado local, porque informações são compartilhadas de modo desigual entre os respectivos espaços sociais referidos.

Ou no dizer de Truzzi (2008, p. 209 - 210):

(...) A informação não é concebida como um bem livre: os indivíduos compartilham e dispõem de informações limitadas, sempre dependentes de sua rede de relações. Nessa perspectiva, são, portanto, as redes de relações sociais que estruturam oportunidades, tanto de partir como de se colocar no novo país.

Outras informações são trocadas e possibilitaram a construção de redes de relações pessoais tecidas durante o trajeto migratório, e que foram importantes para sustentar o ingresso de trabalhadores, sobretudo dos iniciantes, nesse deslocamento para o labor nos canaviais paulistas, como pode ser verificado no seguinte testemunho oral:

Então, no tempo que eu vim veio um amigo meu de lá. Meu amigo não veio muita gente de lá, tudo de Timbiras. Ninguém tinha tanta intimidade, quanto [trecho inaudível], a gente mora no interior. Então, eu peguei intimidade logo com um lá de Timbiras, então [trecho inaudível], ficou logo sossegado. Pode ir, se vai junto, que eu também vou .É, eu fico muito feliz que você vai junto com ele, você é uma pessoa de idade, então ele veio e nós teve um ano sossegado. Não tinha conhecimento de, com ninguém daqui.

\footnotetext{
34 (...) La información no es, por tanto, la misma para todos lós vecinos o coterráneos del pueblo, ni necessariamente se transmite de vecino a vecino, porque los canales a través de los cuales pasa son las relaciones sociales fuertes que prescinden de la distancia y por ende de la frecuencia de los contactos. (...) Em resumidas cuentas: en la misma comunidad de procedência, sobre la base de la concreta articulación de las redes de relaciones de los indivíduos, existe el que tiene información y el que se encuentra desprovido de ella; el que tiene ciertas informaciones y el que tiene otras.
} 
Conhecimento só assim, e nem de lá, porque eu morava no interior. (Jonas, 44. Testemunho oral colhido em Guariba/SP, em 24/10/2010. Caderno de Entrevistas. P. 16)

O testemunho oral do trabalhador rural maranhense acima revela a importância do apego com o amigo de Timbiras, que iniciava, assim como ele, a migração para o trabalho nos canaviais paulistas. A semelhança na postura, diante da "viagem" para São Paulo e na idade cimentaram laços de amizade, que foram fundamentais para enfrentar as dificuldades econômicas, e também psicológicas do deslocamento, porque não tinha conhecimento de, ninguém daqui, ainda mais para uma pessoa de idade, que dividia o trabalho no eito dos canaviais e o aluguel de uma casa na periferia da cidade de Guariba, com muitos rapazes solteiros do Maranhão, com outra postura, e que residiam na cidade de Timbiras. A migração inicial de Jonas para Guariba aconteceu em um período em que a família morava no povoado Santa Maria, no interior timbirense, em que o entrevistado nem conhecia gente da cidade - de lá, porque morava no interior.

As redes de relações sociais, compartilhadas durante a experiência migratória, mesmo que no trajeto entre o município de origem e as cidades paulistas são fundamentais para nutrir o tempo de residência nos locais de destino. De acordo com Truzzi (2008, p. 211): “(..) a própria experiência migratória por si só é capaz de propor e redefinir novas identidades e reconhecimentos que podem traduzir em novas redes. (...)".

Novas redes de relações sociais que foram importantes para a realização da primeira migração de Jonas para o trabalho nos canaviais paulistas, a partir de Guariba, assim como seu significado, presente fortemente na narrativa deste trabalhador de Timbiras.

No entender de Saquet; Mondardo (2008, p. 127):

Pertencer à rede social na migração implica oportunizar recursos e informações, o que permite ao migrante amenizar as dificuldades de sua trajetória, instalação e adaptação, desde sua partida até a hospedagem no local de destino, além da abertura de possibilidades e/ou a garantia do emprego. 
O acesso diferenciado às informações possibilita aos migrantes tecer relações distintas com o trabalho na área canavieira paulista e com o processo migratório da qual fazem parte, e da qual participaram em diferentes momentos de suas vidas. Desta forma, pensamos que a informação, é uma variável fundamental na sustentação da migração, enquanto processo social, pois permite, a partir do fortalecimento das relações de reciprocidade entre agentes sociais, mesmo distantes espacialmente, a garantia material e simbólica a uma gama de oportunidades, conformando nos locais de destino, territorialidades migratórias construídas e recriadas de maneiras diferentes.

Essas informações, sustentáculo dessas redes de relações pessoais também conformam no território, redes técnicas, nas quais, por intermédio direto, via telefone, de forma mais comum, ou Internet, de modo raro, ou a escrita de cartas, que predominou em outros tempos, possibilitam as trocas dessas informações em um circuito de maior confiabilidade, no que reporta às relações sociais primárias. Informações também circulam semanalmente por meio das idas e vindas dos ônibus clandestinos que deslocam semanalmente entre sedes de município do Meio-Norte do país e cidades do Centro-Sul que servem de residência sazonal, fixa ou permanentemente temporária para milhares de homens, mulheres e crianças, famílias inteiras que se põem em movimento em busca de emprego, melhores condições de vida e possibilidades de reprodução do trabalho da família na terra. É o que analisaremos no subcapítulo que se segue.

\subsection{Redes técnicas de apoio à troca de informações que sustentam o processo migratório e as conexões entre os territórios de migração e o local de origem}

Informações diferenciadas trocadas que sustentam redes de relações sociais são nutridas a partir das formas de comunicação entre aqueles que ficaram com aqueles que partiram, e vice-versa. Apoiam-se, sobretudo na difusão de redes técnicas, que possibilitam via telefonia - seja móvel, seja fixa, ou por meio de telefone público - ou por meio da Internet, em menor frequência, essas trocas valiosas de informação, de maneira direta e confiável, sustentando essas 
relações de reciprocidade alicerçadas entre as territorialidades migratórias e os locais de origem.

As redes técnicas que sustentam redes de relações primárias e a troca de informações valiosas entre Timbiras e os territórios de migração, área de estudo deste trabalho, foi amplamente contemplada nos estudos dos geógrafos brasileiros.

Deste modo, podemos mencionar reflexões de diversos geógrafos, que se preocuparam, em diferentes momentos, com a importância das redes técnicas, seja em escala local, regional e global como Claval (1987), Costa (2004, 2011), Dias (2009), Raffestin (1987, 1993), Rouge; Dupuy (1989) e Santos (2002), dentre outros, a partir da discussão de temáticas como redes de transporte, redes de comunicação e informação, rede urbana, rede global ${ }^{35}$.

Santos (2008, p. 91) ao analisar a importância das redes sociais para a migração de sul catarinenses para os Estados Unidos, revela que o uso da categoria redes sociais migratórias fica limitado às redes materiais e físicas, nos estudos geográficos, enquanto que a reflexão acerca das redes sociais são mais desenvolvidas no âmbito da Sociologia.

A autora tece críticas às abordagens da rede social de migração que ao caracterizarem a migração como "um campo de arranjo social no qual as redes de relações familiares, parentais e de amizade são valorosamente representadas" desconsideram o sentido político da migração, esvaziando-o espacialmente, e também da importância da articulação entre redes e territórios (SILVA, 2008, p. 90).

Já Saquet; Mondardo (2008, p.119) consideram que é fundamental uma análise geográfica que possibilite a identificação e a explicação do fenômeno

\footnotetext{
${ }^{35}$ Trata-se das seguintes referências: CLAVAL, P. Réseaux Teritoriaux et Enracinement. In: Cahier/ Groupe Réseaux N N . 7. Paris: 1987. P. 44 - 60. ; COSTA, R. H. Territórios, Redes e Aglomerados de Exclusão. In: O Mito da Desterritorialização. Rio de Janeiro: Bertrand Brasil, 2004. P. 279 - 311. ; COSTA, R. H. O Binômio Território-Rede e Seu Significado PolíticoCultural. In: Territórios Alternativos. 2a . Ed. São Paulo: Contexto, 2011. P. 117 - 128. ; DIAS, L. C. Redes: Emergência e Organização. In: CASTRO, I. E. ; GOMES, P. C. C; CORREAA, R. L. (Orgs.) Geografia: Conceitos e Temas. 12a . Ed. Rio de Janeiro: Bertrand Brasil, 2009. P. 141 162. ; RAFFESTIN, C. Repères Pour Une Théorie de la Territorialité Humaine. In: Cahier / Grupe Réseaux $N^{\circ} .7$ Paris: 1987, P. 2 - 22. ; RAFFESTIN, C. As Redes e o Poder. In: Por uma Geografia do Poder. Trad. Maria Cecília França. São Paulo: Ática, 1993. P. 200 - 220. ROUGE, M. F, DUPUY, G. L'Organisation de l'Éspace et lês "réseaux". In: Flux. Numeró Spécial. Paris: 1989. P. 79 - 87. ; SANTOS, M. Por Uma Geografia das Redes. In: A Natureza do Espaço. São Paulo: Edusp, 2002. P. 261 - 279.
} 
migratório por meio do entendimento de uma abordagem histórica e relacional a partir do processo de territorialização e da interação/articulação em redes. Com isto propõem, a partir de múltiplas relações entre os conceitos de território e migração, uma explicação para a importância das redes de relações sociais na manutenção e nas conexões entre os que migraram e os que não migraram nos territórios de origem e entre os migrantes e os não migrantes nos territórios de migração, nas áreas de destino

Redes territoriais e redes de relações sociais se entrecruzam em várias praticas cotidianas que marcam o processo migratório, como nas atividades de aliciamento, transporte e também de comunicação, a partir dos contatos com familiares, amigos e vizinhos que ficaram e partiram do Maranhão. Portanto em nosso trabalho, é fundamental esta relação entre os territórios conectados, seja na localidade de origem ou de destino, a partir de redes técnicas que sustentam múltiplos fios de redes de relações primárias também entre o cá e os lás que se refazem. Entendemos, que em nossa pesquisa, não é possível conceber territorialidades conformadas por bases técnicas, de forma isolada das territorialidades construídas a partir do processo migratório, até porque uma se apoia sobre outra.

É por isso que não podemos desconsiderar a difusão de equipamentos de comunicação, acionados por redes técnicas, conformando redes territoriais em um sentido mais amplo, e que se encontram instaladas nos municípios de origem e destino.

A expansão da assistência dos serviços à população e o aumento do acesso das redes de telefonia fixa e móvel sobre o território municipal de Timbiras nos anos 2000, possibilitaram os contatos e as trocas de informações entre aqueles que ficaram e aqueles que partiram para diferentes territórios migratórios. Apesar do acesso aos serviços de telefonia, sobretudo a fixa, ser ainda incipiente, no que diz respeito à sua disseminação pelos domicílios timbirenses, o crescimento do atendimento do serviço e instalação dos equipamentos técnicos, permitiu a utilização deste meio de comunicação de maneira cada vez mais crescente entre os que permaneceram e aqueles que migraram para o trabalho nos canaviais, a partir das cidades de Guariba e Pradópolis. Esse fato vale, principalmente para os aparelhos celulares, que apresentaram um aumento 
significativo no seu consumo, entre os trabalhadores canavieiros migrantes, tornando-se não só um dos principais bens materiais cobiçados por estes, a partir do ganho obtido com o labor na safra de cana, mas também possibilitando uma intensidade na frequência dos contatos entre cá e lá.

É necessário, contudo, fazer uma distinção entre o uso do celular como principal meio de comunicação entre os integrantes da família que ficaram em Timbiras e àquelas que partiram. Para o contato efetivar-se, as áreas em comunicação precisam estar cobertas pelo sinal da operadora do equipamento móvel, daí o fato, de que em muitos povoados do interior da área municipal, o telefone público ( os orelhões) constituírem-se ainda como um importante meio de conexão entre esses dois espaços sociais. O mesmo vale, agora, para aqueles que se foram, e se estabeleceram em localidades sem acesso à cobertura das empresas que executam os serviços de acesso de telefonia móvel, e o que é mesmo evitado, por parte dos agenciadores de mão-de-obra e fazendeiros, que aliciam centenas e milhares de trabalhadores migrantes para a execução de serviços no meio rural, em recantos muito distantes de qualquer instalação que permita esse tipo de contato, eliminando assim as trocas de informação, sobretudo entre os familiares, perfazendo assim mais um elemento para a classificação deste tipo de trabalho como sendo realizado em condições análogas ao trabalho escravo contemporâneo.

Retomando a relação da expansão das redes técnicas de comunicação entre Timbiras e os municípios paulistas em tela, sobretudo no que diz respeito à telefonia móvel, o crescimento da frequência dos contatos foi assim registrado por um testemunho oral:

Rapaz, eu falo até três vezes por semana. Eu tenho meu menino que eu falei com ele que eu ia embora, até ele comprou um celularzinho. Ele comprou dois celular, mandou um para a mãe dele e ficou com outro aqui. Então o que ele comprou para a mãe dele está bom, agora o que ele deixou aqui caiu aí, compremos outro, mas já falei para meus amigos aqui do barraco, nós temos dias que eles ligam de lá para mim. Quando eles ligam de lá para mim e não dá certo, eu ligo para lá e dá certo, não é? Nós conversa direto com o outro lá, de lá para cá ou daqui para lá. (Jonas, 44, casado. Testemunho oral colhido em Guariba/SP, em 24/10/2011. Caderno de Entrevistas, p. 23). 
Por meio do testemunho oral de Jonas é possível perceber a frequência dos contatos semanais via celular entre ele, em Guariba e a família, que mora na periferia do núcleo urbano de Timbiras. O filho solteiro, que também migrara para a safra canavieira, e que reside em Guariba em uma casa alugada diferente da do pai, comprara os aparelhos celulares, e enviara para a família que ficou no Maranhão, de modo a permitir a comunicação, e a intensificação da frequência destes contatos semanais, como pode ser observado na fala de Jonas. A quebra do celular do trabalhador rural maranhense foi compensada pela aquisição de outro celular, o que mostra a preocupação do entrevistado na manutenção dessa forma de comunicação com a família no Maranhão e a frequência destes contatos.

Contexto semelhante foi registrado em Timbiras no testemunho oral de Francisca, esposa de Jonas, acerca da importância do celular para a comunicação com o marido e o filho que se encontravam durante a safra canavieira em Guariba.

\begin{abstract}
Pesquisador: $\mathrm{E}$ vocês se falavam muito?
Francisca: Falava, meu menino comprou um celular e ai mandou pra mim, não é? E aí quando chegou aqui, eu mandei ajeitar, porque veio bloqueado, não é? Mandei ajeitar, botei chip pra poder ficar falando com eles. Às vezes na semana nós se falava umas três vezes, duas, era assim. (Francisca, 42, casada. Testemunho oral colhido em Timbiras/MA, em 16/01/2011,. Caderno de Entrevistas, p. 83).
\end{abstract}

As dificuldades superadas associadas ao uso do telefone celular, como o aparelho de Jonas que quebrou ou a aquisição do chip, para desbloquear o equipamento pra poder ficar falando com eles, revelam a importância que esse instrumento de comunicação possui para a manutenção da frequência dos contatos entre os integrantes da família que, durante a safra canavieira, encontram-se separados e divididos espacialmente, uns em Timbiras, outros em Guariba. No entanto, a frequência dos contatos cimentam as relações de reciprocidade familiar, distantes fisicamente, como sustenta o testemunho oral na página seguinte: 
Pesquisador: $E$, com que frequência você fala com a sua família lá em Codó?

Odair: É simples, é celular. Assim, direto eu ligo. Você vê, está bem moderno. Já conversei com a minha irmã hoje. Direto, meu pai, éh... Se eu passar dez dias sem conversar com o meu pai ele já: o que está acontecendo meu filho? Direto, conversa. Frequentemente, graças a Deus, até porque eu conheço pessoas aqui que tem pai, tem mãe, tem irmão e passa um mês, dois meses. Eu não consigo ficar sem ver minha família, é impossível. É igual, esses dias eu liguei para o meu pai, minha filha lhe disse assim: Olhe vô, guarda para mim um cabrito lá, um bode, que nós vamos comer lá. Meu pai: não é, pode vir minha filha. Isso foi em dois mil e seis. Uma vez só. Depois nós viemos de lá. Esse ano, se não for com eles lá, pelo amor de Deus, muito ansioso. Muita vontade de ir. (Odair, 37, separado. Testemunho oral colhido em Guariba/SP, em 24/10/2010. Caderno de Entrevistas, p. 42 - 43).

A necessidade da manutenção dos fios que sustentam os laços com o núcleo familiar, que permaneceu no Maranhão - como a irmã, que conversara no dia em que foi realizada a entrevista, ou com o pai, que "se passar dez dias sem conversar" com o filho em Guariba, liga perguntando: "o que está acontecendo meu filho?" - produz uma aproximação simbólica, nutrida pela permanente renovação dos vínculos de reciprocidade familiar, diferente do caso de pessoas "aqui que tem pai, tem mãe, tem irmão e passa um mês, dois meses, eu não consigo ficar sem ver minha família, é impossível". A perpetuação destes nexos fundamenta o próximo encontro, desejável pelo entrevistado, e que geralmente ocorre após o termino da safra de cana em São Paulo.

Além do emprego massivo do telefone móvel como importante forma de comunicação entre os que partiram e os que ficaram, o uso do telefone público coloca-se como um meio de comunicação fundamental, sobretudo, para os integrantes da família que moram em povoados do interior do município de Timbiras, que não dispõem de cobertura por sinal das operadoras de celular. Os "orelhões" concentrados no núcleo urbano ou nos principais povoados torna-se um centro de aglutinação de pessoas, especialmente nos domingos, para os contatos telefônicos com aqueles que estão distantes geograficamente. 
Antônio, ressalta, em seu testemunho a importância do telefone público para a efetivação do contato com a filha e com o genro, estabelecidos na cidade de Guatapará/SP, antes da disseminação da comunicação inter-familiar por meio do telefone móvel:

Pesquisador: O senhor falava sempre com eles?

Antônio: Falava.

Pesquisador: Quantas vezes, mais ou menos?

Antônio: Todo domingo quase, só quando não dava certo.

Pesquisador: Falava por...

Antônio: Orelhão.

Pesquisador: Por orelhão.

Antônio: Agora esse ano agora, em 2010. 2010, eu digo que não vou lá, mas passei três meses ainda lá. Agora ninguém usava mais orelhão não. Só celular. Daqui mesmo e de lá para cá.

(Antônio, 38, casado. Testemunho oral colhido no povoado Melancia, Timbiras/MA em 20/01/2011. Caderno de Entrevistas, p. 170 - 171)

No testemunho oral de Antônio, nota-se a substituição do uso do "orelhão" para o celular como forma de contato por telefone com os familiares na cidade paulista, a partir de 2010, ainda apontando a sua passagem durante três meses por Guatapará. Temos nesse contexto, o caso do deslocamento de Antônio, para a cidade que servia de residência para a família da filha, na qual o genro dedicava-se ao trabalho na lavoura de cana-de-açúcar.

Os movimentos de agentes sociais pelos dois espaços sociais, engendrados pelas redes de reciprocidade familiar, ocorrem semanalmente, principalmente por meio dos ônibus clandestinos que conectam diferentes sedes de município maranhenses e também piauienses, com os diversos territórios de migração maranhense construídos no Estado paulista. Encontros que se materializam a partir do compartilhamento de redes técnicas imateriais, como via telefone.

Do testemunho de Antônio ainda podemos refletir sobre o contato entre familiares que ficaram no Maranhão e filhos casados, que migraram, e neste caso da esposa que acompanhou o marido nesse processo social.

Nesse ínterim, Silva (2008, p. 5) aponta a importância da mulher para a efetivação destes contatos por telefone, ressaltando aí o seu papel para a 
continuidade dessa comunicação familiar entre os dois espaços sociais. Segundo a autora, este ato ocorre, principalmente nas tardes de domingo, momento em que as mulheres que acompanham a migração dos maridos, pais e até netos, dão notícias daqueles que ficaram no Maranhão. Já àquelas que permaneceram em Timbiras, aglomeram-se com os filhos, nos orelhões do centro da cidade, para obter informações dos que partiram. Por meio dessas considerações de Silva (2008, p. 5) podemos ressaltar o significado da mulher, nesse contexto, sobretudo a casada e/ ou mãe, para a valorização da reciprocidade familiar. Mulher que pode ter migrado, para realizar as atividades domésticas na casa alugada pelo esposo, minorando desta forma, o dispêndio físico diário do marido com as tarefas da casa, caso tivesse migrado sozinho, mas que deixara os filhos aos cuidados dos pais, avós ou irmãos, o que possivelmente explica a frequência das ligações telefônicas para familiares no Maranhão, para obter informações e conversar com os filhos, suprindo simbolicamente a ausência material da mãe, e recompondo a família que encontra separada.

Desse modo informações cá e lá são socializadas, como por exemplo, a necessidade de envio de dinheiro para o trabalho na roça, de orientações para os integrantes da família que ficaram acerca da realização dos serviços na terra, ou mesmo do envio de alimentos e produtos por meio dos ônibus clandestinos que perfazem semanalmente os contatos entre vários municípios do Maranhão, e também do Piauí, com os vários territórios de migração configurados por membros de famílias destes Estados no Centro-Sul do país, especialmente com a área canavieira paulista. É o que podemos observar neste trecho do testemunho de Antônio:

Hoje mesmo, eu fui depositar dinheiro para eles lá, porque lá é o seguinte, esse filho meu [ que está em Timbiras], ele trabalha com roça, aí eu fico mandando dinheiro, aí ele fica administrando, aí ele já tem um estudinho, ele já está fazendo a oitava série, porque quando eu botei eles para a rua, estava muito atrasado, porque até se formar, porque ele é inteligente. Aí eu sempre mando dinheiro, aí ele fica administrando meu serviço. Ele é um cara novo, mas já é bem entendido. Mandei dinheiro para roçar a roça. Quando for para colher eu já deixei lá. Mandei dinheiro para a apanha de arroz, mandei dinheiro para ele roçar a mandioca, porque aí ele tem que roçar, capinar. Aí hoje mesmo eu já 
conversei com ele, aí ele dizendo: papai, agora você tem que mandar um dinheiro para mim comprar um saco, para mim bater o arroz, porque o arroz, o arroz, eu fiz a roça bem pertinho de casa lá, o arroz está ainda na roça lá, e aí ele quer que eu mandasse logo o dinheiro para ele bater o arroz para ir logo para a casa, para a rua. Aí hoje eu fui depositar um dinheiro hoje para bater o arroz e levar para casa. (Antônio, 44, casado. Testemunho oral colhido em Guariba/SP, em 24/10/2010. Caderno de Entrevistas. P. 34)

O entrevistado ressalta em seu testemunho oral o envio de dinheiro, por meio de depósito bancário feito em caixa eletrônico e efetuado pelo mesmo no domingo, dia que foi realizada a entrevista. Falou também sobre a importância que a remessa tem para a organização do trabalho na roça da família que ficou em Timbiras. Aí destaca o papel do filho, de quinze anos, que fica administrando o seu serviço, que conta com o dinheiro mandado pelo pai para roçar a mandioca e comprar saco para bater o arroz e levar para casa. A ida ao caixa automático dos bancos para remeter dinheiro para os familiares em Timbiras, geralmente é feito aos domingos, dia de folga semanal para a maioria dos trabalhadores canavieiros que laboram nas usinas e plantações de cana na região ${ }^{36}$.

Podemos, a partir deste fato, refletir sobre a importância do dinheiro remetido via agência bancária para a organização da vida econômica e social daqueles que não partiram de Timbiras. Informação valiosa trocada via telefone, que configura redes técnicas em um território amplo, e que possibilitam não só a sedimentação dos laços familiares, como também o aporte financeiro necessário para a continuidade do trabalho da família na terra, no Maranhão.

Todavia, não podemos estender essa afirmativa e compreender a intensificação das comunicações por meio do telefone como sinônimo de agudização das relações entre os que ficaram e os que partiram. Rupturas familiares, ocorridas na região de origem, ou criadas no(s) território(s) de

\footnotetext{
36 Já os trabalhadores migrantes que laboram na Central Energética Moreno, usina sediada no município de Luis Antônio/SP, sob o sistema de trabalho conhecido como "cinco por um" não possuem um dia fixo para o descanso semanal, como o domingo, adotado pela maioria das unidades processadoras de cana na região. Por meio desta organização do tempo laboral, trabalha-se cinco dias sucessivos, e folga-se no dia seguinte, que pode incidir-se sobre qualquer dia da semana, o que afeta, sobretudo as práticas de sociabilidade no interior do núcleo familiar, tanto das famílias de trabalhadores locais e dos migrantes estabelecidos, como dos migrantes sazonais que "viajaram" com toda ou a maior parte do tronco familiar e fixaram residência temporária na sede dos municípios de economia canavieira do interior paulista.
} 
migração não se apagam, mesmo com a difusão dos meios técnicos ou a facilidade de encontrar um familiar, parente ou amigo distante ou que há tempos não se tem notícia.

Situação semelhante foi revelada por Maria Elisa ${ }^{37}$, em testemunho registrado em caderno de campo:

Tem sete anos que ele, Eric ${ }^{5}$, saiu para cortar cana. Trabalhou numa cidade paulista e saiu de lá e foi para Monte Aprazível e depois, saiu para São José do Rio Preto para essa morada em José Bonifácio.

Uma pessoa que conheceu ele em Monte falou que ele estava preso há sete meses. Ele foi preso em São José do Rio Preto e foi transferido para Bonifácio, porque lá em Bonifácio ele tinha uns amigos para visitá-lo. Ele foi preso por causa de drogas. O último contato por telefone foi em dezembro de 2008. Ele foi pela fama de ganhar dinheiro. Ele tem vinte e seis anos e ele foi para lá com dezenove anos e já tem sete anos que não vem. Ele mandou $R \$ 470,00$ no início e usamos para desmanchar a casa de palha e colocar telha. (Maria Elisa, 43, casada. Testemunho oral registrado em caderno de campo. Em Timbiras/MA, em 11/01/2010. Caderno de Entrevistas, p. 8)

A falta de informações do filho, que na ocasião da entrevista havia dois anos não ligava para a mãe, bem como a notícia de sua prisão, em função do consumo de drogas, sublinha a ruptura do vínculo familiar por parte do migrante, de cujo paradeiro a mãe não possuía nenhum dado seguro. $O$ rompimento na forma de comunicação usual indicou, neste caso, de uma ruptura nos laços familiares a partir do envolvimento de Eric no mundo das drogas, e sua posterior detenção, em presídio desconhecido, segundo o testemunho da mãe.

Contudo, informações ocasionais advindas por parte daqueles que passaram ou se encontravam no período, nas cidades paulistas que Eric migrou, trazia registros à família no Maranhão sobre o comportamento e as atitudes de Eric, em terras distantes, longe de seu controle, mas não, pelo menos do olhar de certos agentes sociais, da região de origem, que poderia ou não fazer parte de um conjunto importante de pessoas que compunham os fios que teciam suas

37 Eric, Valdomiro, Gilson e Maria Elisa são nomes fictícios. 
redes de relações sociais mais próximas no(s) território(s) migratório(s). Entretanto, a perda de comunicação e a ausência de notícias seguras sobre as andanças do trabalhador migrante, revela a fragilidade da reciprocidade familiar entre os membros que migram e os que ficam, conforme é indicado no testemunho oral de Gilson, irmão de Eric, que também se deslocou para o trabalho na safra canavieira paulista:

Pesquisador: E Gilson, você fala sempre com a sua mãe aqui?

Gilson: É difícil. Eu acho, esse ano passou, eu falei umas duas vezes com ela, durante a semana.

Pesquisador: Por telefone, não é? É complicado manter contato?

[Silêncio]

(Gilson, 21, solteiro. Testemunho oral colhido em Timbiras/MA, em 21/01/2011. Caderno de Entrevistas, p. 286).

Gilson, irmão de Eric, migrou duas vezes para o trabalho no corte de canade-açúcar em usina sediada no município de Sertãozinho, em cuja sede residiu durante as safras de 2009 e 2010, e nessa fala indica as duas vezes, que na última safra acha que falou, com a mãe durante a semana. Os parcos contatos com a mãe em Timbiras, também se reproduzem com outro irmão, estabelecido em Pradópolis:

Pesquisador: E seus irmãos, que estão lá em São Paulo, vocês falam sempre com ele ou não?

Gilson: Com uns eu falo. Daqui, de vez em quando eu ligo. Difícil ligar.

(Gilson, 21, solteiro. Testemunho oral colhido em Timbiras/MA em 21/01/201. Caderno de Entrevistas, p. 286)

A carência de comunicação, nesse caso, não se restringe apenas a mãe, remetendo a possíveis dificuldades ou conflitos entre gerações, mas também na reduzida quantidade de ligações telefônicas ao longo do ano entre os irmãos.

Contudo, as limitações no contato telefônico entre a localidade de origem e os territórios de migração, ou nos diferentes territórios de migração podem ser compensadas por outros tipos de troca de informações, nem sempre seguras e portadoras de confiabilidade, que refletem de certa maneira a influência de um 
controle social direto da comunidade de origem sobre o comportamento dos indivíduos. Informações de agentes sociais que avistaram, conversaram ou souberam de notícias dos trabalhadores migrantes em tela, por exemplo.

Com exceção da situação retratada, tendo como foco o caso da família de Eric, Gilson e Maria Elisa, aos domingos, a conversa entre os que residem durante a safra nas sedes de municípios canavieiros do Estado de São Paulo, e àqueles moradores de localidades do interior do município de Timbiras ou no núcleo urbano deste, são mais frequentes.

Desse modo, a manutenção da solidariedade familiar entre os que partiram, e deste(s) com os que ficaram pode ser fortalecida por meio de redes de relações sociais, desenvolvidas por instrumentos técnicos que possibilitam, por meio da difusão territorial de seus equipamentos correspondentes, a comunicação entre espaços sociais distantes, porém próximos no que reporta às trocas de informações e os contatos primários que amarram os vínculos de reciprocidade.

\subsection{Redes de aliciamento e recrutamento construindo redes territoriais e territórios de migração}

A migração de trabalhadores envolve uma série de agentes sociais responsáveis pelo transporte até os locais de destino, que acumulam uma série de informações sobre o percurso e a duração da "viagem", a acolhida, as possibilidades de conseguir serviço e residência, sem demora. $\mathrm{O}$ controle dessas informações foi vital para a estruturação de uma rede de deslocamento do grupo daqueles primeiros maranhenses que partiam dispunham de informações confiáveis e de um apoio nas cidades paulistas, de integrantes da família, parentes e amigos já estabelecidos nesses núcleos urbanos.

Portanto, inicialmente, na quase ausência de informações seguras e de contatos de integrantes do lugar, sobre seus locais de destino, agentes sociais locais dispunham do controle de informações requeridas por aqueles que não as possuíam, tais como percurso de longa distância da "viagem", acolhida e adequação ao serviço nas cidades receptoras. Este terreno era movediço, sobretudo para aqueles que iriam passar pela sua primeira experiência migratória, em uma região e em uma atividade econômica - corte de cana - que poucos 
tinham o que contar. $\mathrm{O}$ mesmo vale para aqueles que já haviam partido para outros locais e que labutaram nas mais diversas funções, no campo ou na cidade - no garimpo, na reforma de pasto, na construção civil, nas atividades de retirada da cobertura vegetal, no roçado da juquira - na qual a experiência do trabalho no Centro-Sul canavieiro, sobretudo, no Estado de São Paulo, ainda era uma novidade nos itinerários migratórios que perfizeram em suas vidas. Poucos tinham familiares já estabelecidos na região, vindos em outras épocas como Antônio, e que já representavam um ponto de apoio no Estado de São Paulo:

(...) eu tenho uma irmã que mora aqui em Ribeirão, e aí ela tem o que? Mais de vinte e dois anos que ela mora aqui. Agora a pouco o meu cunhado acabou de sair daqui. Todo domingo quase ele vem aqui onde nós estamos aqui e eu tenho eu e outro irmão meu que mora aqui em baixo, lá em baixo, perto do posto de gasolina, esse tá aqui desde 2005. Eu aproveito também que aqui, eu vou até aqui, já desde 2006, eu transferi o meu título para cá, pois é. (Antônio, 44, casado. Testemunho oral colhido em Guariba/SP, em 24/10/2010. Caderno de Entrevistas. P. 33).

O testemunho de Antônio faz alusão ao estabelecimento definitivo da irmã, a mais de vinte e dois anos na cidade de Ribeirão Preto. Os motivos da migração da irmã, não foram buscados, mas a sua residência em Ribeirão Preto, a 64 quilômetros de Guariba, também serviu de apoio, para suportar os desgastes, sobretudo os de cunho econômico e psicológico - advindos do deslocamento inicial para a cidade paulista. Tal base familiar sustentou vínculos de reciprocidade familiar mantidos também no local de destino, e que se fortaleceram, com a chegada do irmão, estabelecido em Guariba, desde 2005, município de votação do entrevistado após a transferência de seu título de eleitor. A partir deste registro oral, temos indicações da tendência do entrevistado de fixar-se definitivamente no núcleo urbano guaribense, após uma possível "viagem" para o Maranhão para trazer os integrantes da família que lá ficaram como foi proferido por Antônio:

Se eu vir ainda para cá, eu não vou dizer que eu saí assim, como aí muitos que saem dizendo, rapaz, eu não venho mais não. Se eu vir para cá ainda, mas eu vou trazer a 
minha família, porque pelo menos a gente trazendo a família da gente para cá, por um lado é melhor porque a gente chega em casa, ela já fez as coisas para a gente, para a gente chegar, a gente e daí cozinhar, aí é chato demais ("Tonheiro", 44. Testemunho oral colhido em 24/10/2010, em Guariba. Caderno de Entrevistas. P. 34)

As possibilidades seguras de informação, obtidas por integrantes da família estabelecidos há mais de vinte e dois anos na região de destino, com os quais mantinha ligações recíprocas, apesar da neblina, quanto ao desempenho do trabalho na cultura canavieira, não eram compartilhadas por muitas famílias maranhenses. Desse modo, foram os agentes sociais nos municípios maranhenses, ligados às redes de deslocamento e aliciamento, os principais certificadores das garantias de segurança durante a viagem, de casa, trabalho e de um "bom salário" no local de destino.

Essas pessoas, que atuavam/ atuam no município de origem dos trabalhadores migrantes são associadas a donos de empresas de ônibus - que atuam no âmbito regional nos Estados do Maranhão e do Piauí, e depois também em outros Estados, como Goiás - e ao fornecimento de trabalhadores para usinas e grandes plantadores de cana no Centro-Sul - empreiteiros ou agentes ligados diretamente às usinas - com presença ativa junto aos municípios do Maranhão e Piauí que se configuram no local de moradia destes trabalhadores, assim como nas cidades paulistas, que servirão de residência ao longo da colheita da canade-açúcar.

As informações de origem não familiar, de uma fonte não segura, era conhecida por parte de muitos trabalhadores, que experimentaram "viagens" de longa distância e duração para outras regiões do país, em outros tempos, que se traduziam em "ilusão", "enganação", principalmente por parte dos agenciadores dessa força de trabalho, os conhecidos gatos. "Conversa bonita", "sedutora", que mesmo com o desencantamento produzido no local de destino, era noutros momentos acionado, em razão da escravidão permanente da precisão, das condições cada vez mais precárias de reprodução social familiar na terra, conforme nos revelou Moura ( 2009) no capítulo 1. 
A respeito do aliciamento de trabalhadores maranhenses da região dos Cocais, Aragão (2008, p. 220), ancorado nos ensinamentos de Hannah Arendt, pondera sobre os imperativos da necessidade, forçando homens pobres a sujeição, a sua conversão em servos da necessidade e das vontades alheias dos gatos. De acordo com o autor:

Sem dúvida, a necessidade perpassa a história da humanidade, da Grécia Antiga aos nossos dias, forçando homens pobres à sujeição. No Maranhão, por exemplo, no âmbito da questão agrária, ela tem sido um dos elementos que favorecem o processo de migração de grandes contingentes de camponeses transformados em trabalhadores volantes e sazonais para diversos Estados do Brasil, assim como um forte motivador para que esses camponeses aceitem, sem muita desconfiança, promessas enganosas dos "gatos". Aragão (2008, p. 220).

O excerto acima evidencia a vulnerabilidade de camponeses pobres, sujeitos ao deslocamento compulsório e à vontade dos aliciadores, mesmo sabendo do trabalho penoso e da fala falsa dos "gatos" do lugar em razão da precariedade das condições de reprodução da vida.

Tal qual esse histórico de desconfiança diante desses recrutadores locais em muitas regiões do Maranhão ${ }^{38}$, esse sentimento, acentua-se em relação ao aliciador forasteiro, vindo de outro Estado, e diretamente da usina.

Desse modo, arregimentadores locais que se associaram aos interesses dos donos de empresas de ônibus, que atuavam inicialmente no Meio-Norte, formaram a base para a criação nas principais sedes de município de origem destes trabalhadores migrantes para a lavoura canavieira das agências de viagem.

A agência de viagem é um estabelecimento físico, onde se encontra uma pessoa responsável pela venda de passagem a diferentes destinos - locais que requeriam força de trabalho, e muitas vezes ofereciam serviços realizados em condições aviltantes e que exigiam pequena qualificação técnica. Veja a Figura 29, a Figura 30 e a Figura 31:

${ }^{38}$ Vide exemplo de Silva( 2008, p. 208) 


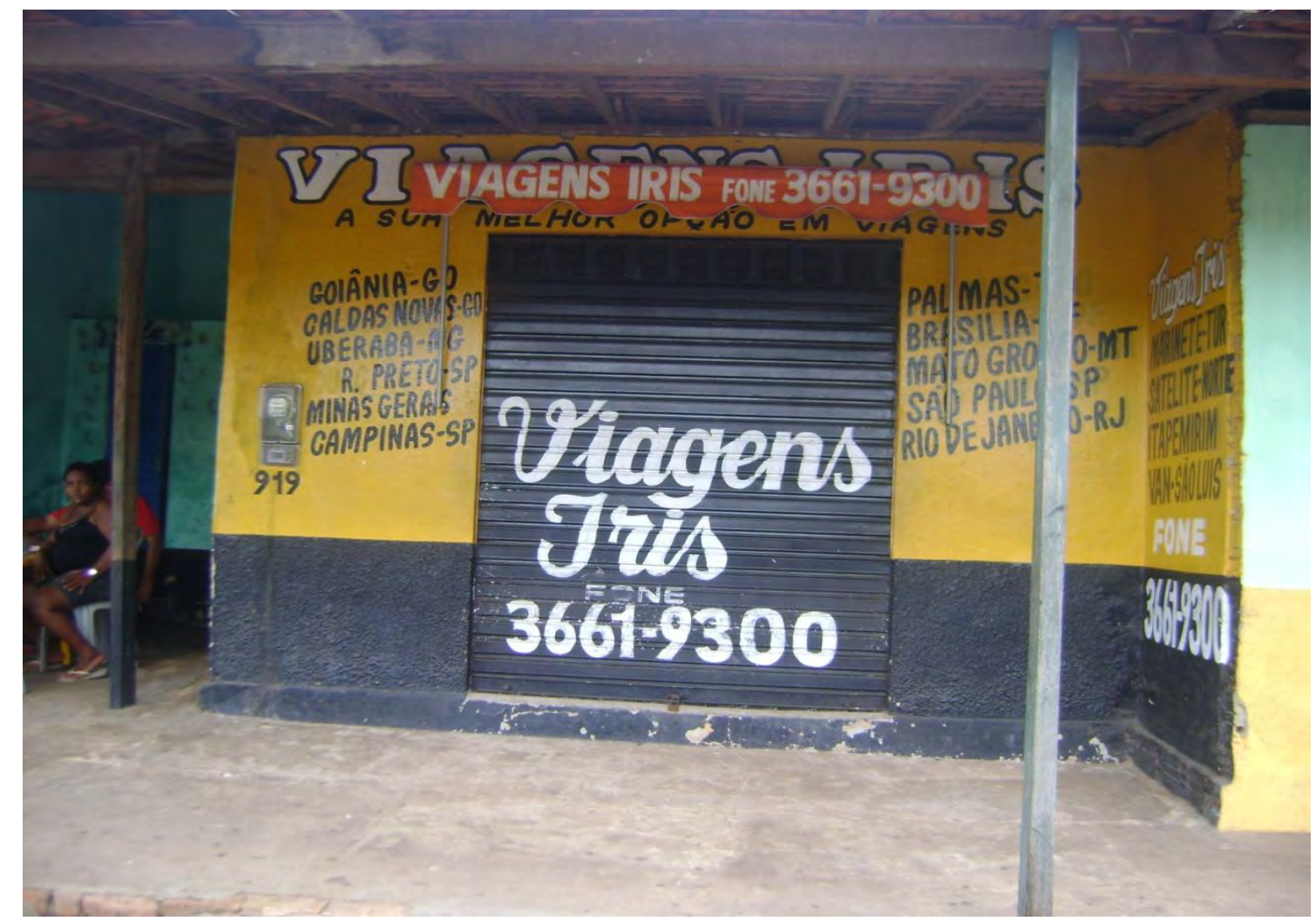

Figura 29 - Agência de viagem na cidade de Codó/MA.

Fotos do autor, 09 de janeiro de 2010.

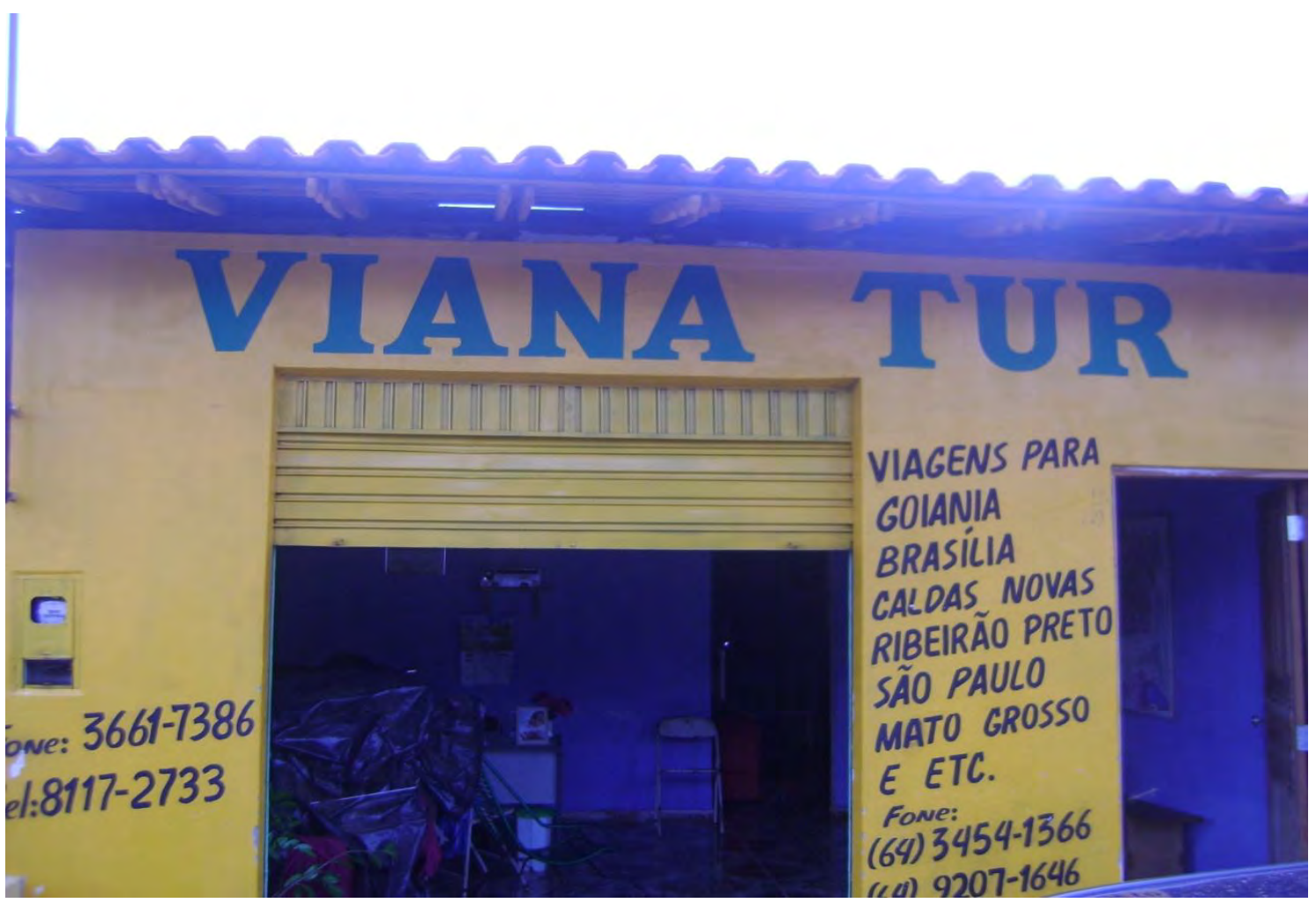

Figura 30 - Agência de viagem na cidade de Codó/MA.

Fotos do autor, 09 de janeiro de 2010. 


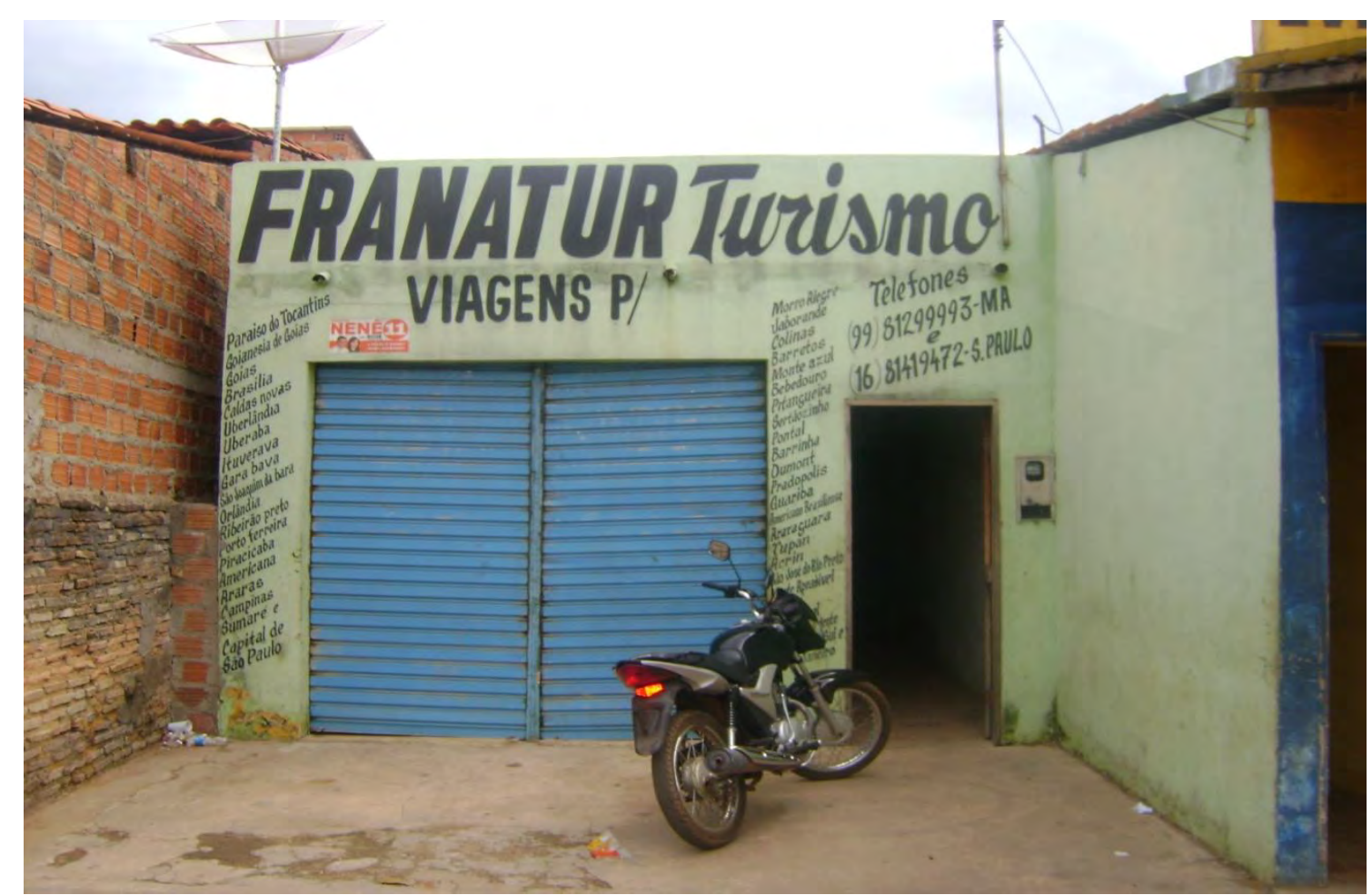

Figura 31 - Agência de viagem na cidade de Coroatá.

Fotos do autor, 09 de janeiro de 2010.

Nota-se nas figuras 29 a 31, na fachada das agências de viagem, os itinerários dos ônibus clandestinos para importantes rotas de trabalho degradante no Centro-sul do país, incluindo aí várias cidades paulistas que servem de residência para os trabalhadores durante a safra canavieira.

No que reporta a territorialização das redes de relações sociais que sustentam o deslocamento de trabalhadores maranhenses, em particular de Timbiras, Marinho (2010, p. 11) analisou como acontece o deslocamento destes agentes sociais para o trabalho na lavoura canavieira e os principais responsáveis pelo processo de intermediação, examinando seus posicionamentos e estratégias.

Nesse ínterim, a função do agente de intermediação abrangeria desde o recrutamento de trabalhadores até o seu deslocamento para áreas canavieiras, e sua operação se efetivou por meio de múltiplas redes tecidas entre empresas de ônibus clandestino, donos de agencia de viagem - que seriam os vendedores de passagens de algumas empresas de ônibus clandestino, que podem contar também com agentes móveis nesta venda de passagens em municípios vizinhos que ainda não possuíam uma agência de viagem e que apresentavam grande 
demanda por este tipo de deslocamento, como era o caso do município de Timbiras, no início dos anos 2000 - arregimentadores de força de trabalho (os chamados gatos) e os migrantes.

A partir da venda de passagem facilitada e com um menor preço em relação às empresas de ônibus, que operavam a partir de linhas convencionais e com regularização oficial, as agências de viagem proliferaram em Codó, na década de 1990 (MARINHO, 2010, p. 20), a partir da venda de passagens de empresas de ônibus clandestino, alocadas em outros municípios do Estado do Maranhão, Piauí, Goiás e São Paulo. Estas empresas de ônibus clandestino articulavam redes territoriais, a partir de nós, representados pelos principais municípios no Estado do Maranhão e também do Piauí, que apresentavam forte migração para o trabalho degradante nos canaviais do Centro-Sul, em particular para o Estado de São Paulo, mas também para outras regiões caracterizadas igualmente por condições degradantes de trabalho nos Estados do Pará, Mato Grosso e Goiás. Em muitos desses municípios havia uma "agencia de viagem". Estas ligações envolvem desde a venda de passagens, por parte das agências de viagens nos núcleos de origem, até a recepção e o transporte de retorno, feito semanalmente, e intensificado após o término da safra para os municípios de origem.

Segundo Marinho (2010, p. 20), as vendas de passagem em ônibus clandestinos no município de Timbiras se processaram a partir de agencias de viagem situadas em Codó, antes do aparecimento da primeira agência de viagem timbirense. Intermediários a partir de agencias de viagem de Codó vendiam essas passagens do clandestino na sede do município estudado.

Nessa instalação, ocorre a partida e a chegada de ônibus clandestinos, veículos que pertenciam a empresas que não possuíam a certificação das autoridades competentes, em diferentes níveis administrativos, para operar no transporte de passageiros como as empresas de ônibus convencional que atuavam no âmbito regional, estadual ou até interestadual, e que possuíam uma série de requisitos legais que tinham que cumprir para obter a concessão dos itinerários. 
Difere-se, entretanto, das empresas de linha, que possuem oficialmente esse registro, e teriam que atuar dentro de horários e itinerários preestabelecidos de origem e destino.

Muitos "ônibus de linha" oferecem roteiros cujo destino se assemelha ao oferecido pelas agencias de viagem. No entanto, o que chama a atenção do trabalhador que se desloca por estes espaços sociais é o custo da passagem de ônibus, mais em conta, com maiores facilidades de parcelamento, e com uma série de vantagens por envolver gente conhecida, e que se desloca semanalmente entre o Maranhão e São Paulo, trazendo, e também controlando informações valiosas, que vão sendo transmitidas e repassadas para lá e para cá. Informações que vão se traduzindo, em fortes relações pessoais desses trabalhadores, com os agentes associados à estas redes de deslocamento e aliciamento, que camuflam as condições de exploração exercidas por estes sobre os trabalhadores migrantes.

Notícias que vão e vem por meio dos agentes sociais associados aos percursos semanais dos ônibus clandestinos, que além do transporte dos trabalhadores migrantes, levam e trazem informações entre o município maranhense e os paulistas: da família que ficou, dos acontecimentos no Maranhão, da saúde daqueles que labutam nos canaviais:

Essas relações se estreitam, na medida em que uma territorialidade cada vez mais precária em porções dos Estados nordestinos - em especial do Maranhão e Piauí, no Meio-Norte - limitam as possibilidades de reprodução social dessa fração do campesinato, e oferecem reduzidas oportunidades de emprego no meio urbano para os seus descendentes, fortalecendo as redes de deslocamento e aliciamento, que tecem itinerários e delimitam territorialidades precárias, também noutras paragens.

É também por meio das redes de relações pessoais que criaram esses itinerários entre diversos municípios, é que se efetiva o vai e vem de produtos, sejam os originários da agricultura camponesa, vindos do município em tela, no Maranhão, sejam aqueles adquiridos a partir do ganho advindo do trabalho penoso nas atividades da gramínea no Estado paulista: 
Pesquisador: E o senhor sempre trás coisas de lá para cá? Como é que... Manda alguém trazer?

Antônio: E aqui, quando os caras maranhense traz, ela se torna muito cara aqui porque lá prá nós, o saco de cinquenta quilos, lá está cinquenta reais. Os caras que tem dinheiro aqui; aqui maranhense traz de lá compra lá na razão de cinquenta reais, chega aqui eles querem vender a base de duzentos reais o saco. Aí a gente que as vezes a gente que tem lá, aí a gente pede para a família da gente: rapaz, põe meio saco de farinha. A gente manda o dinheiro, aí eles coloca dentro do ônibus, paga aquela taxa, que é, um saco de farinha, eles estão cobrando quarenta reais num saco, eles cobram quarenta reais, se você for trazer uma quantidade, eles fazem uma diferença, mas se você trazer só um saco, eles cobram quarenta reais. Aí as vezes eu mando a mulher botar, as vezes, meio saco, bota quinze quilos para fornecer. Às vezes a gente manda pedir, às vezes pedir outras coisas, assim quando é verdura de roça. As vezes, no período da verdura de roça ela mandava para mim, mandava para mim. Só nunca mandou foi melancia, mas assim, e agora de verdura, quiabo, maxixe, essas coisas, tudo vinha de lá do Maranhão para aqui e aí a gente embala dentro de uma caixinha de isopor, aí vem tranquilo. Chega aqui [trecho inaudível] na hora. Limão, essas coisa tudo, às vezes quando eu peço assim eles mandam.

(Antônio, 44, casado. Testemunho oral colhido em Guariba/SP, em 24/10/2010. Caderno de Entrevistas. P. 35)

O envio de produtos entre os municípios do Maranhão e os núcleos urbanos receptores, no Estado de São Paulo, por meio de ônibus clandestino, se realiza mediante a cobrança de uma taxa, que no caso do saco de farinha de mandioca é de quarenta reais, custeado pelo trabalhador maranhense, valor que se aproxima ao preço de venda, em Timbiras, que segundo, o entrevistado encontra-se na faixa dos cinquenta reais. Mesmo assim, é cobrado dos migrantes, um preço superior ao praticado por comercializarem o saco de mandioca em um valor até quatro vezes maior ao praticado no município maranhense. Outros produtos obtidos da roça da família, como verdura, quiabo, maxixe, limão é remetido de Timbiras para Guariba pelos ônibus clandestinos, minorando deste modo os custos com alimentação realizados na cidade paulista, que comprometem já os seus parcos rendimentos.

Marinho (2010, p. 11) fez um levantamento acerca dos intermediários que articulam o deslocamento sazonal de trabalhadores do município de Timbiras 
para o trabalho na lavoura de cana-de-açúcar do Estado de São Paulo, verificando como se posicionam e quais estratégias são utilizadas para viabilizar a mobilidade desses trabalhadores migrantes. Apontou a frequência das viagens semanais ao longo do ano, o preparo da família e do trabalhador rural para o deslocamento de longa distância, os agentes sociais envolvidos no transporte e no recrutamento desta força de trabalho até as cidades paulistas que servirão de residência durante a safra de cana-de-açúcar.

A autora coloca que os clandestinos partem do núcleo urbano de Timbiras na sexta-feira, e chegam ao seu local de destino, no domingo, portanto, antes do início dos dias uteis na semana, período de arranjar trabalho na atividade canavieira. Esse registro foi lembrado em muitos testemunhos orais:

A atenção que foi dada a este problema da migração também foi a partir de 2005 que a gente passou a ver mais a chegada de ônibus mais, cada vez mais saindo, 2005,2006, e aí foi aumentando, não é? Aí em 2007, pelo menos foi aquele a cada sexta-feira saindo cinco ônibus, não é, meu amigo, era coisa de... Era muita gente saindo demais, a cidade ficava pequena, não é?

(Domingos, 24, agente da Pastoral da Juventude em Timbiras. Testemunho colhido em 18/01/2011, na cidade de Timbiras/MA. Caderno de Entrevistas, p. 119).

A intensificação da migração para o trabalho nos canaviais do Centro-Sul, especialmente para o Estado de São Paulo, na segunda metade dos anos 2000, é percebida pela rápida chegada e saída de ônibus na cidade, transportando centenas de trabalhadores migrantes, toda sexta-feira, em que cada semana, a cidade ficava pequena. Esse período coincide com a elevação do processamento de cana-de-açúcar e fabricação de açúcar e etanol pelas principais unidades agroindustriais canavieiras, empregadoras de mão de obra migrante, em particular do Estado do Maranhão, como foi observado no capítulo dois, isto é, a intensificação do processo migratório coincide com a intensificação do ritmo do processo produtivo na área canavieira paulista. Na partida, momento de despedirse dos que ficam, de renovar as esperanças para um tempo que passa "logo", de fazer as malas, levando objetos e lembranças da terra de origem, para suportar a ausência e a saudade da família que continua em Timbiras. Vide a Figura 32: 


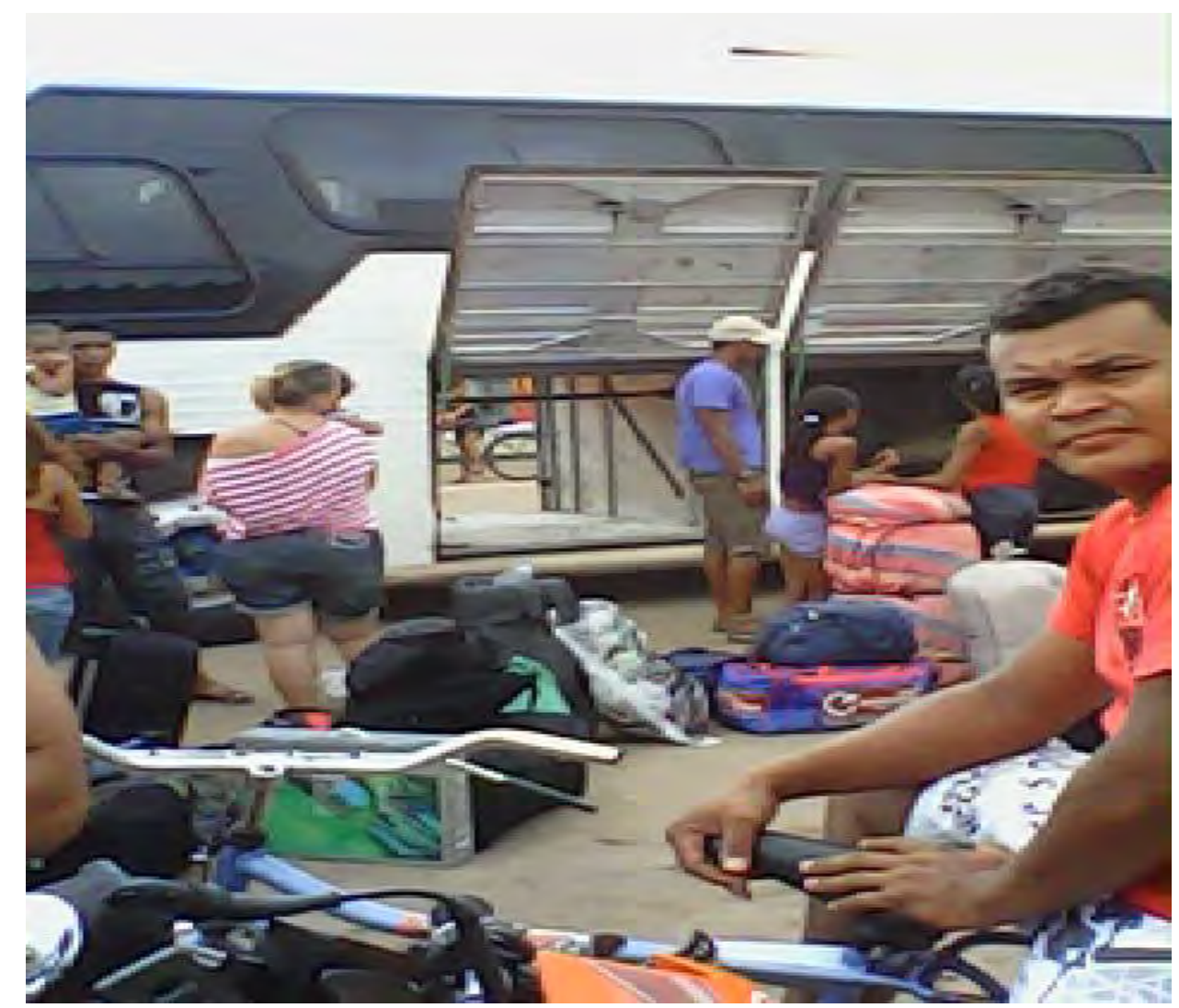

Figura 32 - É hora de partir. Arrumação das malas e pertences pessoais no bagageiro de ônibus clandestino em Timbiras/MA.

Foto de Domingos Roberto Feitosa Tavares, 28 de Janeiro de 2011.

A presença de familiares, amigos, vizinhos e de pessoas que já experimentaram essas andanças, ou que se preparam para fazê-la, nas partidas dos ônibus clandestinos rumo aos destinos de trabalho degradante dão força para uma frágil condição de reprodução social marcada pela pobreza, pelas incertezas econômicas e pela vulnerabilidade da oferta de trabalho no município de Timbiras. Tem se agora, o inicio de parte de outro percurso repleto de expectativas e muitos desafios: os três dias de viagem até as cidades canavieiras do Estado de São Paulo.

A partir da pesquisa desenvolvida por Carneiro et al. (2007, p. 216 - 217), a ocorrência das viagens para a área canavieira paulista concentra-se nos quatro primeiros meses do ano, período que antecede o início da safra na maior parte das unidades processadoras do Centro-Sul canavieiro. Das 114 famílias entrevistadas pelos pesquisadores, 13,95\% afirmaram que o deslocamento de seus integrantes realizou-se no mês de janeiro, 17,44\% afirmaram que ocorreram em fevereiro, $32,55 \%$ em março e $11,62 \%$, em abril, ou seja, $75,56 \%$ do total das 
viagens realizadas durante $o$ ano. A concentração do número de viagens no mês de março indica o retorno de trabalhadores contratados principalmente para 0 corte de cana, e que durante o período da entressafra ficaram com o tronco familiar no município de Timbiras, e também dos que vão se deslocar pela primeira vez para a labuta na colheita da gramínea, e que antecedem sua chegada às cidades do interior paulista, com o objetivo de procurar casa e trabalho, apoiado nas redes de relações sociais aí estabelecidas.

Os dados obtidos por Carneiro et al. (2007) constataram a continuidade dos deslocamentos de trabalhadores maranhenses do município de Timbiras para o trabalho nas lides dos canaviais nas cidades do Centro-Sul, especialmente no interior paulista, ao longo dos demais meses do ano. Esse resultado vai ao encontro das considerações de Alves (2006, p. 92 ) a respeito da forte demanda das unidades processadoras de cana-de-açúcar de trabalhadores canavieiros que apresentam elevada produtividade diária de trabalho no corte manual da gramínea, aumentando o ritmo da produtividade agrícola, e consequentemente o rendimento agroindustrial, e os lucros dos empresários do setor sucroenergético. Os trabalhadores migrantes que se sujeitam e suportam essas metas permanecem em seus empregos, e tem posto garantido na próxima safra. Os que não atingem os objetivos estipulados pelas empresas, são demitidos no decorrer da safra pela usina, desistem e regressam para o Maranhão nos ônibus clandestinos.

A migração para o trabalho nos canaviais nas cidades do Centro-Sul nos primeiros meses do ano é indicada no testemunho abaixo:

Pesquisador: E como o senhor foi daqui para lá?

Antônio: Nos ônibus clandestino. Foi por conta mesmo. Foi levado assim.

Pesquisador: Em que época o senhor foi para lá? Em que mês do ano?

Antônio: É no mês de março.

Pesquisador: No mês de março?

Antônio: Mês de março. Eu fui no dia 10 de março.

(Antônio, 38, casado. Testemunho oral colhido no povoado Melancia, Timbiras/MA, em 20/01/2011. Caderno de Entrevistas, p. 168). 
A lembrança da data de partida para o interior paulista foi lembrada com precisão por parte do entrevistado, o que revela a importância dessa experiência migratória para a sua vida e de sua família. Aliás, este fato ocorreu em outros testemunhos orais colhidos em Timbiras, Codó, Pradópolis e Guariba.

Segundo, Francisco, 36, casado, proprietário de bar em Pradópolis, a viagem de Timbiras a Pradópolis foi feita por um ônibus clandestino, por meio de uma agência de viagem em Codó. Disse que houve troca de ônibus umas três vezes durante a viagem (Testemunho colhido em 08/08/2011, na cidade de Pradópolis/SP. Registro em caderno de campo. Caderno de entrevistas, P. 316).

$\mathrm{O}$ trajeto de Timbiras para várias cidades do interior paulista abrange a passagem por rodovias sob a administração do governo estadual e federal em vários Estados, e fiscalizada por parte das autoridades competentes. A ilegalidade da viagem em clandestinos e as péssimas condições de manutenção do veículo tornam as paradas frequentes, para o conserto do ônibus ou pendências com o aparato policial nas rodovias, condição que faz com que os clandestinos se aventurem por estradas pouco vigiadas, nem sempre trafegáveis, o que implica severamente no estado de conservação do veículo e na duração da viagem.

Vettorassi (2010, p. 190), elenca os riscos, as incertezas e a ilegalidade da operação das viagens realizadas pelos ônibus clandestinos: possibilidades de roubo na estrada, de problemas mecânicos e a apreensão do veículo por fiscais nas rodovias, devido a precariedade das condições de viagem, de problemas de acidentes de trânsito, em razão da não permuta de motoristas durante o percurso, causando ferimentos, danos materiais e até mesmo a morte.

Esta travessia por vários Estados do país faz lembrar a saga e os dilemas do percurso arriscado de migrantes ilegais no espaço internacional. Guardadas as especificidades e as devidas proporções dessas rotas ilegais, a ausência de passaporte, no caso brasileiro, não subtrai a situação vulnerável, precária e degradante da viagem destes homens, mulheres e famílias pobres, que assumem os riscos de um itinerário repleto de incertezas em procura de trabalho, realizado em condições desumanas.

Roteiro perigoso que também se faz na "volta" para os Estados de origem, no término da safra, que estremece o coração de quem há muitos meses aguarda o abraço apertado e o convívio roubado da família. É tempo de levar para o 
Maranhão, o pouco que conseguiu juntar, e assim, comprar o terreno e construir uma casa para efetivar o casamento, reformar a casa, levantar a parede de alvenaria e colocar as telhas de cerâmica, comprar móveis e eletrodomésticos, roupas e calçado para as crianças, dinheiro para iniciar a plantação e tocar os serviços do roçado, adquirir uma moto, para facilitar a locomoção até o interior do município e cidades próximas ou para ganhar a vida realizando serviços de mototaxi, montar um comércio na cidade e viver do seu ganho, e assim ficar de vez na" terra da gente". Como e até quando, é o que perceberão quando chegarem nas suas localidades de origem. Para outros, a "viagem" tem prazo de validade:

Pesquisador: E você chegou quando Raimundo?

Raimundo: Aqui?

Pesquisador: É.

Raimundo: Foi anteontem, foi dia dezenove. Ontem foi vinte, hoje é vinte e um. Dezenove.

Pesquisador: E você volta quando pra lá?

Raimundo: Eu estou pensando, depois do dia doze. Acredito que sim.

(Raimundo, 27, casado. Testemunho oral colhido em 21/01/2011 na cidade de Timbiras/MA. Caderno de Entrevistas, p. 260 - 261).

A partida de Raimundo, próximo da metade de fevereiro, revela as estratégias do entrevistado de realizar pequenos serviços durante a entressafra em Pradópolis, e preparar-se para a colheita da lavoura da gramínea que inicia-se em maio. Ao contrário de muitos testemunhos colhidos, Raimundo procura qualificar-se profissionalmente em Pradópolis, para posteriormente trabalhar no núcleo urbano de Timbiras, dedicando-se não apenas a agricultura camponesa. De certa forma, as expectativas de Raimundo quanto ao futuro assentam-se nas incertezas de reprodução social da família na terra, enquanto camponeses intensamente subordinados às práticas de arrendamento, e da idade avançada dos pais, que fixaram residência definitiva em um bairro na periferia de Timbiras.

No início da pesquisa de campo, centrada no município de Timbiras, tivemos a oportunidade de acompanhar o desembarque ${ }^{39}$ de um grupo de

\footnotetext{
${ }^{39} \mathrm{Em} 10$ janeiro de 2010, assim que chegamos na cidade de Timbiras, na metade da manhã de domingo, uma agitação tomou conta da hospedagem onde nos estabelecemos. Uma senhora, proveniente de Pradópolis, e alocada na mesma hospedagem, notou que não éramos do local e
} 
trabalhadores migrantes, que residiram durante a safra canavieira na cidade de Santa Rosa de Viterbo, nas cidades de Timbiras e Coroatá. Durante o percurso de trinta e seis quilômetros pela rodovia MA 235, percebe-se na paisagem, a destruição dos babaçuais, como podemos observar por meio da Figura 33.

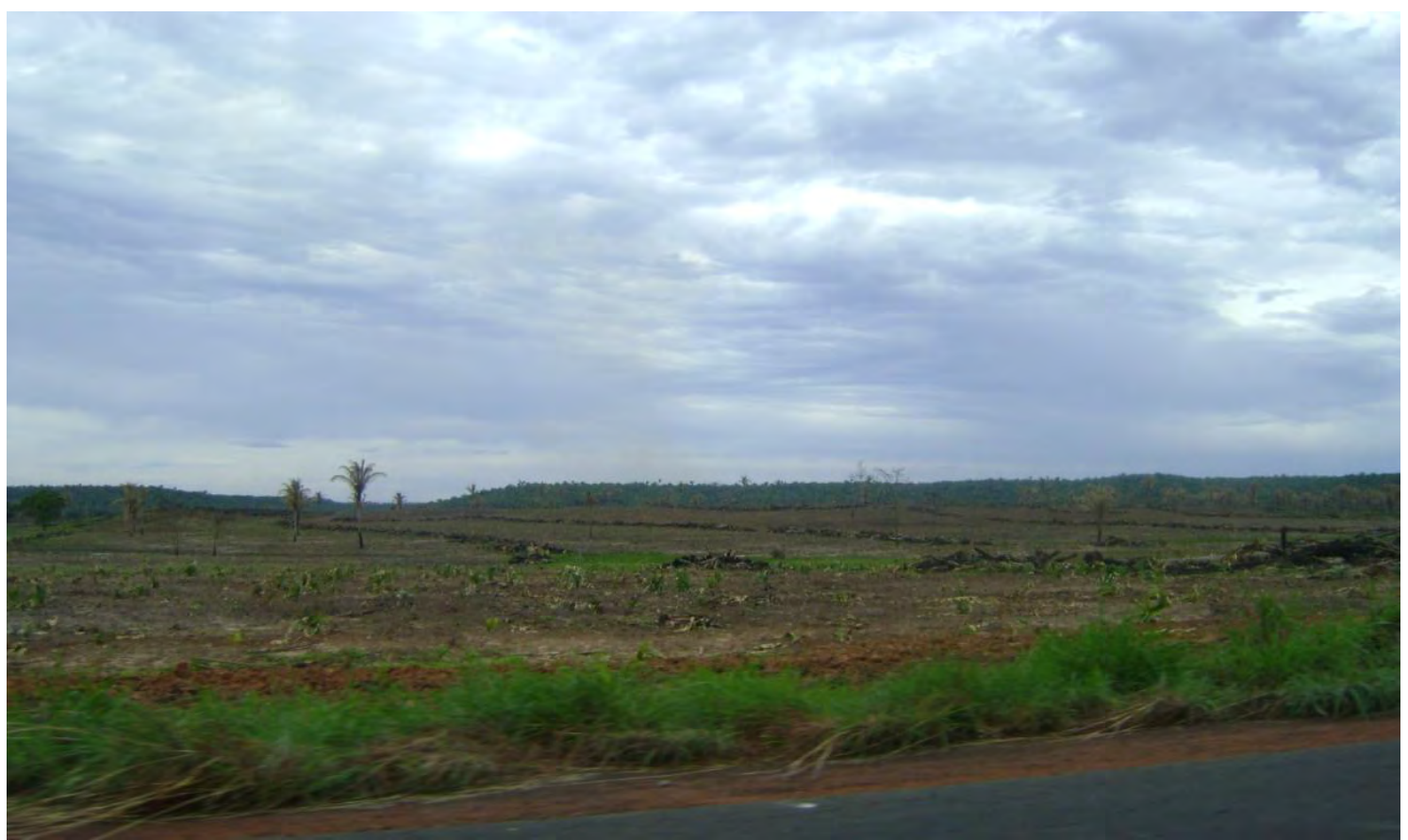

Figura 33 - Terra arrasada. Destruição dos babaçuais em faixa de terras próxima à rodovia MA 235, sentido Coroatá -Timbiras.

Foto do autor, 10 de Janeiro de 2011.

A destruição das áreas ocupadas pelo babaçu reflete o processo de pecuarização em curso nos estabelecimentos rurais no Estado do Maranhão, e também na microrregião geográfica de Codó, como pudemos analisar de forma mais detida no capítulo um. À margem do roteiro realizado pelos trabalhadores migrantes encontra-se a atividade econômica que predominou no oeste e

perguntou sobre o que fazíamos ali. Apresentamos-nos como pesquisadores paulistanos que estudam a migração de maranhenses para o trabalho no corte de cana em São Paulo, e ela se identificou como intermediária na venda de passagem entre o interior paulista e os estados do Maranhão e Piauí. Disse se gostaríamos que os acompanhassem em uma viagem de automóvel de Timbiras para Coroatá, a fim de recepcionar a chegada de um ônibus de trabalhadores rurais de Timbiras e Coroatá, que partiram três dias antes da cidade de Santa Rosa de Viterbo, município paulista que serviu de área de estudo em nossa pesquisa de Mestrado. Seguimos com a intermediária nesta ação até o início da tarde. Foi registrada a chegada destes trabalhadores, e por meio de conversas informais, obtidas algumas informações sobre o trabalho nos canaviais, a usina em que trabalhavam e a cidade na qual residiam temporariamente. Também foi buscado o contato com o informante timbirense que encontrei na sede do STR em Santa Rosa de Viterbo, no início de 2008, sem sucesso. (Pesquisa de campo, janeiro de 2010). 
noroeste paulista, região de grande expansão da área ocupada com a lavoura canavieira durante os anos 2000.

$O$ desembarque de trabalhadores e familiares, que retornaram das atividades na lavoura canavieira da Usina Santa Rita e Central Energética Moreno e alocados na cidade de Santa Rosa de Viterbo/SP. A longa espera é aguardada por todos: trabalhadores, familiares e amigos, como pode ser verificado por meio da Figura 34 e da Figura 35.

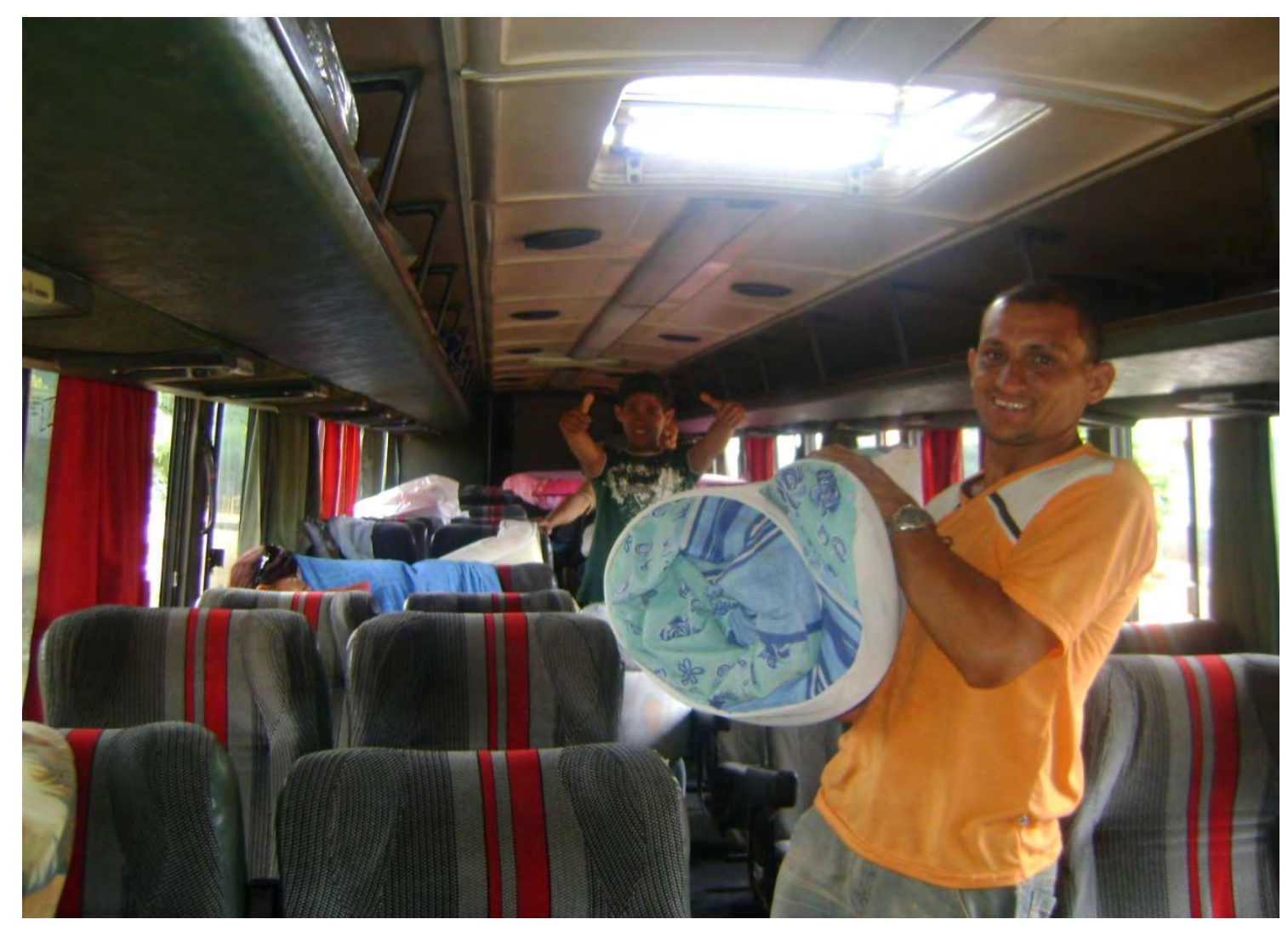

Figura 34 - Chegada dos filhos da terra (1). Coroatá/MA. Foto do autor, 10 de Janeiro de 2011. 


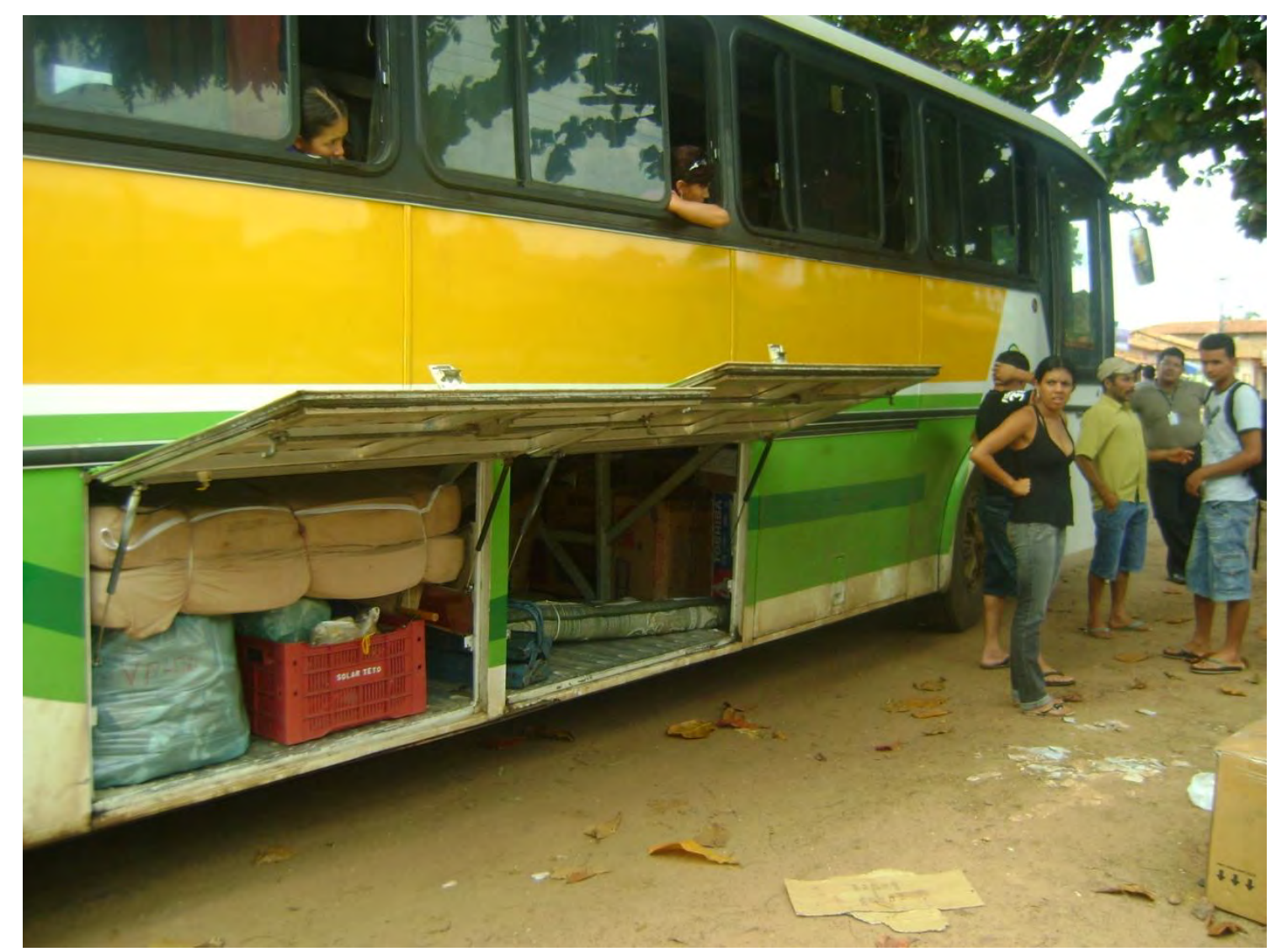

Figura 35 - Chegada dos filhos da terra (2). Coroatá/MA. Foto do autor, 10 de Janeiro de 2011.

$\mathrm{Na}$ bagagem do ônibus, notam-se os pertences pessoais, os produtos e equipamentos que custaram o trabalho penoso no eito dos canaviais.

Para outro grupo de trabalhadores maranhenses, a "viagem" para o Maranhão após o término da safra pode não ter volta, pelo menos durante o tempo desejado pelo trabalhador maranhense. Quando o período de colheita é estendido para outras semanas, além do período previsto da safra, em algumas unidades processadoras, efetua-se o adiamento da viagem do trabalhador para o município de morada da família. Percebemos este acontecimento, por meio do testemunho oral de José, que foi o último trabalhador maranhense a deixar a casa alugada na qual residiam os entrevistados em nossa pesquisa de campo, em outubro de 2010, na cidade de Guariba para "viajar" para Timbiras. O adiamento da viagem para Timbiras, conforme o registro do entrevistado deveu-se ao adiamento do término da safra 2010, concluída em vinte e sete de dezembro, e cujo acerto salarial só se realizou no início de janeiro do ano seguinte, conforme aponta o entrevistado: 
Pesquisador: José, você chegou quando aqui em Timbiras? José: Eu cheguei no dia sete de janeiro, a partir da uma hora da tarde.

Pesquisador: E como é que você saiu de lá?Você veio, como é que foi a viagem?

José: Foi bom, viu! Graças a Deus, o que importa é a viagem, com confiança, e não tem acidente, não tem outros tipos de coisa. É bom para a gente, chegar em paz, e ver a família da gente.

Pesquisador : Quantos dias você demorou? José: Três dias.

Pesquisador: Três dias de lá pra cá. E aí, os colegas que moravam com você lá, na casa, em Guariba, também alguns vieram para cá, e outros ficaram lá?

José: Vieram tudinho. O último quem ficou foi só eu.

(José, 26, solteiro. Testemunho oral colhido em 21/01/2011 na cidade de Timbiras/MA. Caderno de Entrevistas, p. 265).

O atraso da conclusão da safra na Central Energética Moreno representou a ausência do entrevistado nas comemorações festivas de fim de ano, junto aos seus familiares no Maranhão: "Vieram tudinho. O último quem ficou foi só eu". Representou também a espera nos seus planos de conhecer a filha, nascida em outubro de 2010. (Caderno de Entrevistas, p. 279). Ao contrário de Raimundo, e outros entrevistados, José, não tinha pretensões de voltar para São Paulo na próxima safra: "Vou ficar um ano aqui, eu fico, que a partir do outro ano, eu acho que talvez eu volto lá. Acho que em 2012, não é, que agora eu não quero ir lá não". (Caderno de Entrevistas, p. 266).

A migração para o trabalho nos talhões de cana da mesma unidade agroindustrial, a partir da residência na mesma casa e cidade em São Paulo na safra passada não é garantida no próximo ano. As estratégias da família podem associar períodos intercalados de permanência do trabalhador maranhense no local de origem, o trabalho na unidade camponesa, e o deslocamento para o assalariamento na mesma atividade econômica exercida no município paulista ou em outras noutros municípios e Estados do país. Neste último caso, José, também expressa tal situação com relação aos companheiros timbirenses com quem dividiu o aluguel da casa em Guariba, no ano de 2010, a partir da exibição da imagem fotográfica tirada na pesquisa de campo em outubro, na cidade paulista: Esse daqui, eu acho que está no Mato Grosso, esse baixinho aqui. 
Deste modo, não podemos pensar na migração, como processo social que invoca as mesmas áreas de origem e destino. Como foi exposto anteriormente, origem, destino, trajeto, se metamorfoseiam, experimentam novas relações e significados.

Apesar de ter distância e duração aproximadas, o deslocamento de municípios do Maranhão para o Estado de São Paulo, não tem o mesmo significado no movimento inverso do percurso. Com exceção dos perigos da "viagem", Raimundo pronuncia:

(...) Deu até um problema agora, nós chegamos, nós saímos lá em Pradópolis, às seis horas, mais ou menos, por aí, chegamos em Goiânia, quase seis horas da tarde, bom, quase seis horas do dia, ainda estava amanhecendo, aí, nós paramos lá de cinco horas do dia, até três horas da tarde, para poder dar continuidade na viagem. Problema do ônibus lá. É isso aí. E a vida continua, entendeu?

(Raimundo, 27 Testemunho oral colhido em 21/01/2011 na cidade de Timbiras/MA. Caderno de Entrevistas, p. 263).

As expectativas quanto ao reencontro com os integrantes da família que ficaram no Maranhão, são antecedidas por momentos de angústia no trajeto, de espera nas longas paradas e sofrimento com o tempo de viagem que acompanham "o percurso da precisão", conforme associa Pontes (2010), destes agentes sociais, do Maranhão para São Paulo, de São Paulo para o Maranhão.

O custo financeiro, a duração e as paradas para desembarque de passageiros no Estado maranhense foi assim posta por Domingos:

Pesquisador: Domingos, você acabou de chegar de lá. Você veio de ônibus?

Domingos: Foi.

Pesquisador: Ônibus de linha, ou ônibus, que chamam aqui, de agência?

Domingos: Clandestino.

Pesquisador: Foram quantos dias de viagem?

Domingos: Três dias.

Pesquisador: Três dias de viagem. Vocês saíram de lá então...

Domingos: Segunda-feira.

Pesquisador: E, só para eu ter uma ideia, qual é o preço, mais ou menos, da passagem? 
Domingos: Rapaz, eu paguei cento e cinquenta.

Pesquisador: Três dias de viagem. E a maior parte do pessoal desce todo mundo aqui em Timbiras, ou vai parando?

Domingos: Uns param em Peritoró, em Coroatá, Timbiras e Codó.

(Domingos, 21, solteiro. Testemunho oral colhido em 19/01/2011 em Timbiras/MA. Caderno de Entrevistas, p. 134).

O desembarque dos migrantes e dos integrantes de sua família que o acompanharam durante o seu período de trabalho no eito dos canaviais, grafam o trajeto e as cidades que constituem o nó desta multifacetada rede de relações pessoais que interpõem agentes sociais cá e lá, aproximando, de forma contraditória territorialidades distintas experimentadas e que impigem marcas na vida destes homens, mulheres, crianças e famílias.

Para driblar as dificuldades deste percurso, que se refazem no futuro, e da vida familiar marcada pela precariedade e por tantas incertezas, Vettorassi (2010, p.190-191), em seu trabalho acerca das dimensões objetivas e subjetivas presentes em redes sociais e grupos de migrantes de Serrana e Guariba, no interior paulista, assim coloca:

(...) Para a garantia de sobrevivência e melhores condições de vida, há uma necessidade muito maior de contar uns com os outros para suprir as carências de um Estado deslegitimado e impotente, que nem sequer pode contar com um comércio eficiente, como o que poderia ser feito pelas empresas de ônibus. As relações simbólicas, comunitárias e muitas vezes ilegais são mais eficazes do que as regras e normas institucionais que estão muito pouco presentes em seus locais de origem.

Desta forma, a construção de redes de relações sociais a partir do espaço comunitário, mesmo operando de forma ilícita, como demonstra a viagem por ônibus clandestino, supre, a partir de estratégias precárias, arriscadas e transitórias, as necessidades mais fundamentais da vida social, de agentes sociais imersos em um prolongado processo de empobrecimento, diante de um 
Estado legal que não garante e muito menos supre essas necessidades essenciais no local de origem.

A experiência internalizada por homens, mulheres, crianças, famílias inteiras que se fazem migrantes, se apoiam nestas práticas cotidianas como estratégias para viabilizar a vida, ainda que de uma forma precária, degradante, desumana.

Assim como Silva (2008, p. 6), o pesquisador pensava que a circulação de ônibus entre o município de moradia da família dos trabalhadores no Maranhão e as cidades no Estado de São Paulo restringia-se ao início e ao término da safra canavieira. Também pensava que o deslocamento destes agentes sociais limitava-se ao setor sucroalcooleiro no Estado de São Paulo.

Por meio deste veículo, processa-se o vaivém de informações, produtos, objetos e lembranças, contudo, revela também a face perversa do agronegócio canavieiro paulista, que descarta todos aqueles que não se enquadram em seus ritmos de produtividade de trabalho na agricultura canavieira: agentes sociais que não atingem as metas de produtividade diária (quantidade pré-estabelecida para o corte de cana, a partir da relação tonelada de cana/ homem/ dia requerida pelas unidades processadoras da gramínea) e são dispensados pelos turmeiros e representantes das usinas, trabalhadores que não suportam as condições degradantes de trabalho, e temendo contrair ou agravar problemas de saúde voltam para as suas regiões de origem, sem sequer fazer o acerto com a usina, como lembra Francisco, morador timbirense que migrou sucessivas vezes para o trabalho nos canaviais paulistas:

Francisco: ... (...) Aí, mas eu tava muito era doente, não podia mais fazer nada. Aí eu tomei, não quis dizer pra ela, senão elas se apavoravam aqui, não é? Era eu falar, eu tava doente, ela tava ouvindo, o que é que faz? Nessa na última hora, não é, eu é quem ficava. Eles ficava aperreado aqui, não é, aí eu, eles me deram alta e aí eu fui, tornei ir pra cana, quando eu olhei eu fiquei lá. Rapaz, tornei, rodou, rodou, rodou, e eu fiquei, sem saber mais, do mundo. Quando eu me acordei, eu tava lá no hospital, lá na usina. $E$ aí o médico falou: rapaz isso aí não tem jeito, e aí, e aí eu digo: doutor como é que eu vou me embora? Eu não tenho carro, não tenho ticket, nem dinheiro aqui, não tenho parente nenhum aqui, só tenho conhecido meu aqui, como é 
que eu vou me embora? Ele disse, não tem jeito [breve pausa]. Pode esfriar a cabeça, não esquenta não, agora eu já sei que você está bem melhor, você está já conversando, então tá bom!

Domingos $^{40}$ : : E o que o senhor fez?

Francisco: Chama o rapaz lá, o gerente lá da usina, da Maringá, só pra pagar o rapaz aí que não pode mais trabalhar, ele tem que ir embora. Doutor, e... Ele precisa. Se o rapaz não pode, tá com três vezes que ele caiu, como é que ele pode ficar? Muitos deles já morreram aqui, gente lá de Codó já morreu com esses mesmos sintomas, [barulho de moto] e aí foi obrigado a pagar os direitos, que não queriam pagar, e aí tava ruim desse jeito. Disse ele, que ele é o seguinte, que eu não tava pedindo pra ir embora, o que, que ele podia fazer? Ele não pode trabalhar. Vamos embora aqui mais eu. Saí com meu camarada, quase sem saber do tempo, você pode assinar aqui?

Domingos: Sem nem ler o que tinha.

Francisco: (...) Eu tava ruim, mas, botei no bolso, digo aí, amanhã eu vou me embora. O menino lá não tava sabendo ainda que eu ia embora quando eu cheguei: menino,amanhã eu vou embora! Eh, rapaz, se eu não posso trabalhar, tá com três vezes que eu caio aqui, da última vez pode ser que eu não acorde, pois eu vou me embora. Rapaz, eu digo, éh, é digo, olha aí meu contrato lá eu já risquei lá e pronto. Não vou mais não. Rapaz, eu quero que você diga desse jeito: eu comprei minha passagem, e nesse mesmo dia, comprei minha passagem, rapaz, eu saí lá pra Pradópolis, saí mais cedo, três horas da manhã, pra gente estar viajando lá pra Pradópolis, lá nos pega o buso correndo, cheguemos lá, aí perguntou dois aqui de Timbiras: rapaz, eu vou embora lá pra minha terra, e o cara não deu baixa na minha carteira, (...)

Francisco: Ele disse: eu vou dar baixa em carteira nada rapaz, eu tô indo embora pra minha terra, eu não vou ficar mais aqui não, depois fosse desse jeito. Aí depois, nós vimos todo mundo junto, faltava cinco passageiros. Aí nessa hora, nós chegamos em quatro. O outro rapaz era de lá, de Pradópolis mesmo, e aí nós fizemos por dentro do bolso e... viemos embora, desse jeito.

(Francisco, 57, casado. Testemunho oral colhido em 20/01/2011, no povoado Flores, Timbiras/MA. Caderno de Entrevistas, p. 242 - 244).

${ }^{40}$ Domingos de Feitosa Carvalho foi o principal interlocutor nesta atividade de campo para os povoados do interior do município de Timbiras. Felix foi o condutor do moto-taxi, na referida pesquisa de campo. 
Por meio de seu testemunho oral, Francisco expõe o temor de contrair problemas graves de saúde que comprometam sua atividade produtiva, o sustento e a execução de seu trabalho no interior da unidade camponesa, a partir da roça da família, ou até mesmo perder a vida, diante de um ritmo de trabalho extenuante no eito dos canaviais, longe de casa, da família, da terra, em um local estranho. Segundo o entrevistado, que "tava muito era doente, não podia mais fazer nada, e não queria apavorar" a família em Timbiras, a ida ao médico, não solucionou seu problema de saúde, pelo contrário, o profissional de saúde, a serviço da usina, liberou o trabalhador rural, recomendando o seu retorno ao trabalho, até porque não poderia contrariar a diretriz de seu empregador, que é o de maximizar a produtividade agroindustrial do processamento de cana, determinação que envolvia o ritmo intenso de trabalho exigido dos canavieiros, principalmente no corte da gramínea. Como foi esboçado, no capítulo anterior, a morte de 21 trabalhadores rurais na lavoura canavieira paulista, no local de trabalho, entre os anos de 2004 e 2009, aumentaram a pressão de instituições fiscalizadoras, como o Ministério Público do Trabalho e a Delegacia Regional do Trabalho da região de Ribeirão Preto, determinações que foram sequer levadas adiante pelas unidades agroindustriais, como comprovam diversas blitz realizadas pelas instituições públicas mencionadas. . O medo de perder a vida no local de

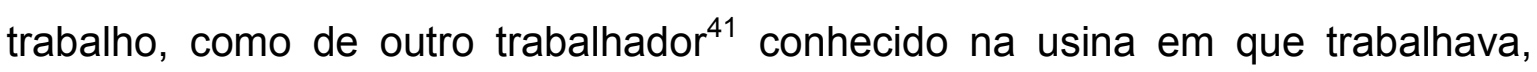
acelerou a partida de Francisco para junto da família, em Timbiras e partindo com mais quatro trabalhadores migrantes de Pradópolis para o Maranhão, a partir do ônibus clandestino, na mesma semana que viu tudo rodar no eito dos canaviais.

Outrossim, em outubro de 2010, na semana em que foi realizado a pesquisa de campo em Guariba, pelo ônibus clandestino chegou Francisco, 28, casado, pai de dois filhos, e de um próximo no ano vindouro. O que levava Francisco até Guariba, outra vez, agora nos meses finais da safra, não era obviamente, o "fichamento" para o trabalho no corte no corte de cana. O que trazia Francisco até a cidade paulista foi mais uma tentativa de fazer a perícia,

\footnotetext{
41 Trata-se de Valdecy de Paiva Lima, 38 anos, natural de Codó/MA, falecido no hospital São Francisco de Ribeirão Preto, em julho de 2005, devido a um acidente cerebral hemorrágico, e sepultado em Codó/MA.

(Fonte: http://www.pastoraldomigrante.org.br/index.php?view=article\&catid=47\%3Amemoria...) Acesso em 30 Jun. 2010
} 
para conseguir o benefício da aposentadoria por invalidez, situação que o afastou do trabalho, desde 2004, quando trabalhava na então Usina São Carlos, onde adoeceu e que depois de seis meses foi afastado. Distrofia muscular: "Fiquei três anos sem ir para o Maranhão, a usina não deixava. (...). A usina não deu nenhuma assistência". (Testemunho colhido em Guariba/SP, em 24/10/2011. Registro em caderno de campo. Caderno de entrevistas, p. 55)

Francisco ${ }^{42}$ viajava de São Paulo para o Maranhão, do Maranhão para São Paulo, fazendo perícia cá e lá, sem garantir um direito que é seu: "Mandam eu ir para lá e fazer a perícia lá, depois mandam eu fazer aqui,e não resolvem nada. Não consegue aposentar." (Testemunho colhido em Guariba/SP, em 24/10/2011. Registro em caderno de campo. Caderno de entrevistas, p. 56)

Seis anos em busca dos direitos. Viaja com recursos próprios, em ônibus clandestino; já foi assaltado nesses ônibus. "Eu queria resolver isso logo para não ficar viajando. É difícil" (Testemunho colhido em Guariba/SP, em 24/10/2011. Registro em caderno de campo. Caderno de entrevistas, p. 56)

\footnotetext{
${ }^{42}$ Na pesquisa de campo, realizada em janeiro de 2011, no município timbirense, tentamos entrar em contato com a família de Francisco, que mora no povoado de Axixá, situado na porção centronorte da área municipal de Timbiras, a pelo menos sessenta quilômetros do núcleo urbano. Em virtude das chuvas frequentes no verão, e das dificuldades de locomoção, até por motocicleta, no período que foi realizado a pesquisa, seguimos as recomendações de nossos informantes locais a não avançar até o referido povoado. Segundo José, trabalhador timbirense que estava presente no momento do registro do testemunho de Francisco em Guariba/SP:

Pesquisador: E ele conseguiu?

José: Ele não conseguiu a perícia, mas a usina fez um tipo de acordo com ele, que quando ele tava doente, a usina deu baixa na carteira dele, aí ele não tava recebendo. Ele pôs na justiça, e tá correndo atrás. Tá o quê? Tá com cinco anos, esse negócio aqui. Desde 2005. E ele é deficiente, sei que ele não faz nada.

Pesquisador: Então chegou a acordo nenhum lá?

José: Chegou não. Ele falou pra mim que ia ganhar alguma coisa, mas só que ele não conseguiu. Pesquisador: E aquele acerto com a usina?

José: Isso é mais com a usina e o sindicato, porque a usina São Carlos, ela afasta os caras, os trabalhadores rurais e aí com o tempo, elas despacha eles, não aposenta. Que o direito dele era se aposentar pela usina, e não foi aposentado. Que o direito era de aposentar mesmo, porque tá recebendo o salariozinho de cortador de cana, não dá, e não dá para ele sustentar a família dele.

Pesquisador: Ele mora longe, ele mora em Axixa, não é?

José: Axixá. Nem eu sei onde é. Só ouvi falar o nome. Até ele falou de modo pra eu ir lá, mas eu nunca fui.

Pesquisador: A gente tentou ir lá de mototaxi, mas disseram que a estrada estava ruim, e que dava sessenta quilômetros.

José: É longe.

(José, 26, solteiro. Testemunho oral colhido em 21/01/2011 na cidade de Timbiras/MA. Caderno de Entrevistas, p. 271).
} 
A morte lenta, produzida no consumo da força física e da saúde do trabalhador rural ao longo da sua vida nas lides nos canaviais, se materializa na vida abreviada de inúmeros mutilados que vivem escondidos nas periferias das cidades canavieiras da região de Ribeirão Preto, como coloca Silva (2008, p. 8 10), condenados e abandonados pelo labor nos canaviais, sem poderem trabalhar e assim garantir o sustento de suas famílias, sem acesso aos direitos sociais e trabalhistas resultantes de suas vidas dilaceradas, ceifadas e reduzidas no eito dos canaviais.

As territorialidades precárias da família cá e lá são experimentadas também no percurso, durante a viagem dos trabalhadores migrantes nos ônibus clandestinos.

Seu Sebastião, 70, pai de um trabalhador canavieiro maranhense, em Pradópolis, ficou quase todo o primeiro semestre de 2011 para tratar-se de uma doença, tendo como apoio o polo médico hospitalar de Ribeirão Preto. Ficamos surpresos em reencontrá-lo, em Pradópolis, pois registramos o testemunho oral de Seu Sebastião e sua esposa, em janeiro de 2010, falas que destacavam o drama e as perdas ocasionadas pela enchente na bacia hidrográfica do rio Itapecuru, em maio de 2009, que atingiu a casa da família, além do descaso do poder público em relação a real recuperação das famílias diretamente atingidas na inundação. Um ano depois, em janeiro de 2011, tivemos a oportunidade de colher o testemunho deles, agora em um outro contexto, com a presença do filho, Raimundo, que há quatro anos não os visitava em Timbiras em razão do trabalho na atividade canavieira, a partir de Pradópolis. Agora, em agosto de 2011, quem nos recebia no portão da casa alugada de Raimundo, no final da tarde na cidade paulista, era dona Maria Cleonice, que acompanhava Seu Sebastião, no tratamento do problema de saúde em Ribeirão Preto. No dia em que realizamos a pesquisa de campo, em Pradópolis, Seu Sebastião e dona Maria Cleonice também iriam "viajar" para Timbiras, e aguardavam ansiosamente a passagem por lá do ônibus clandestino.

Durante o encontro, Seu Sebastião falava da proximidade da chegada ao Maranhão, depois de tanto tempo longe de casa. $O$ estranhamento experimentado em relação à Pradópolis favorecia tais expectativas. Mas era chegado o momento da partida, de enfrentar os riscos dessa travessia: a 
despedida da família do filho que fica, mas os descaminhos de um percurso, que está longe para ser desconsiderado, e reduzido a passagem. Partir, para a família pobre de trabalhadores rurais maranhenses significa "viajar" de ônibus clandestino. Depois de uma longa espera, que se estendeu durante boa parte da noite, a chegada repentina e rápida do meio de transporte, refletia também as dificuldades e a demora na volta para Timbiras. Veja a Figura 36 e a Figura 37:

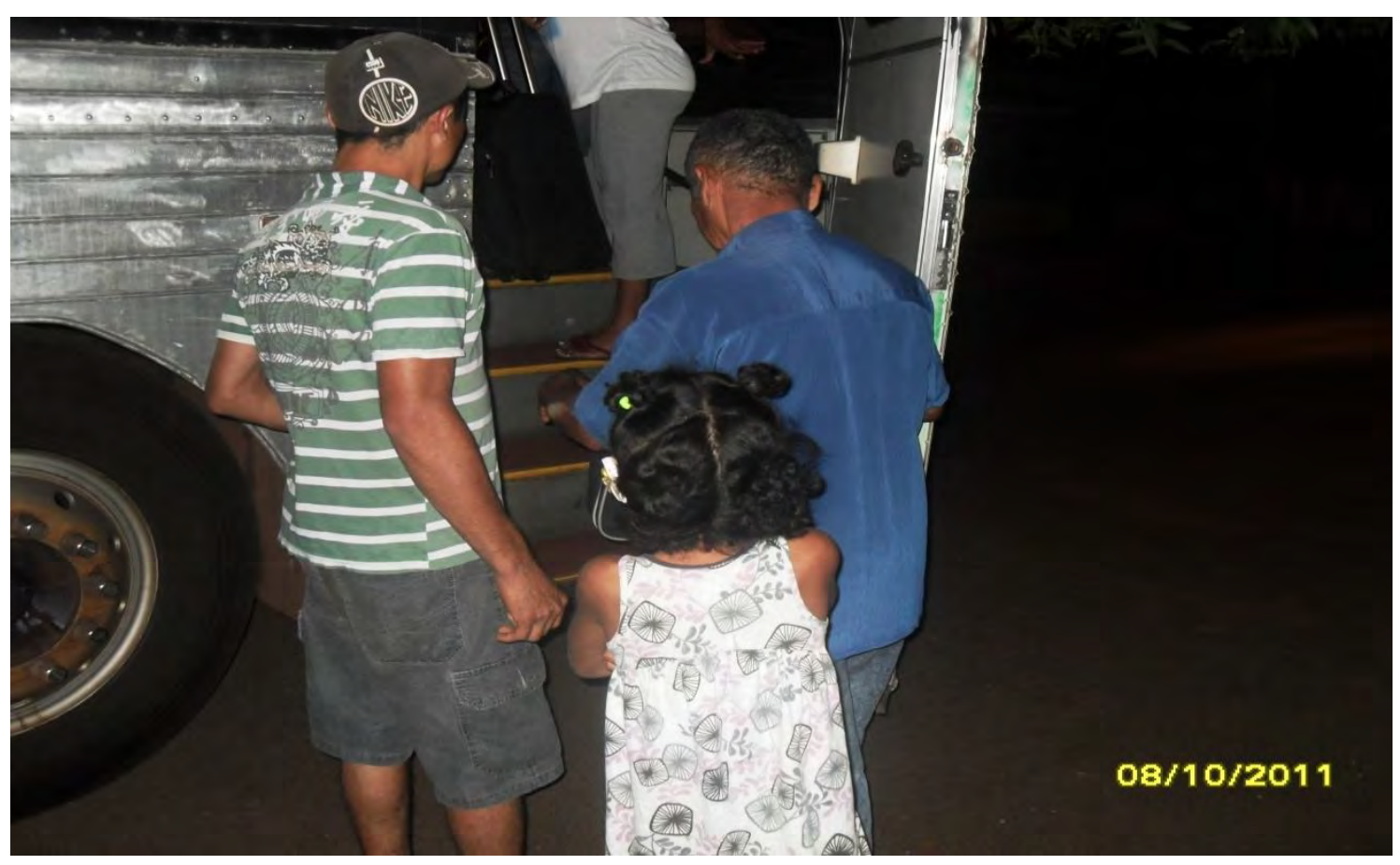

Figura 36 - Despedida da família em Pradópolis/SP. Raimundo auxilia o pai a instalar-se no ônibus clandestino, rumo a Timbiras, no Maranhão. Era próximo das 22 horas e seriam mais três dias de viagem até os pais desembarcarem no município maranhense. Pradópolis/SP.

Foto do autor, 8 de agosto de 2011. 


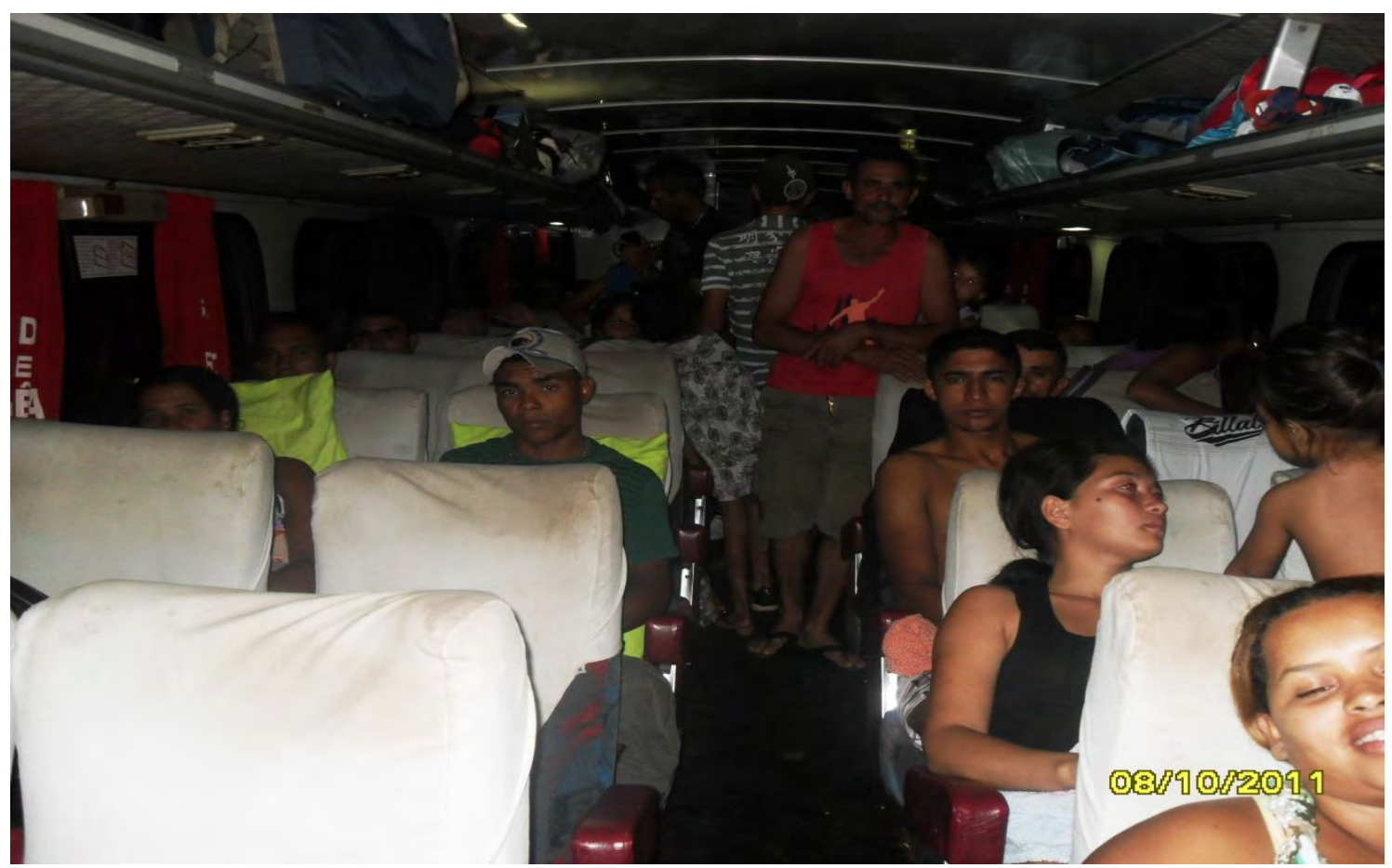

Figura 37 - No interior do ônibus clandestino. Após passar por várias sedes de municípios canavieiros do nordeste paulista, o ônibus parte lotado para os locais de origem das famílias dos trabalhadores migrantes. Pradópolis/SP. Foto do autor, 8 de agosto de 2011.

O contexto da realização da pesquisa de campo em Pradópolis revelou que a aproximação do entendimento da realidade social não se dá por esquemas interpretativos pré-estabelecidos, atividades pré-elaboradas e situações sob o controle do pesquisador. Estávamos diante de fragmentos da vida social que não eram inesperados como o vaivém dos ônibus clandestinos durante o período de safra.

Esse itinerário se reproduz na sede de municípios maranhenses conhecidas na pesquisa de campo, como Timbiras, Coroatá e Codó, que se situam próximas das rodovias utilizadas no transporte destes agentes sociais até o Estado de São Paulo. Percebemos, também, por meio dos testemunhos orais que muitas pessoas deslocam-se de municípios vizinhos e de outros ainda mais distantes no Maranhão, para cidades que se constituíram em nós, desta intrincada rede de deslocamento de trabalhadores migrantes e, de parte de suas famílias, para as atividades associadas a agricultura canavieira. Este foi o caso de Daiane, 18, casada, cuja família, residia na cidade Santa Luzia, na porção centrooeste do Estado do Maranhão, distante a 237 quilômetros de Timbiras, município em que embarcou, por meio de ônibus clandestino para Guariba: 
Pesquisador: Como é que vocês saíram de lá e vieram pra cá? Vocês vieram em ônibus?

Daiane: Nós viemos de ônibus até em .... Porque nós havíamos perdido o ônibus, saímos de lá era uma hora já. Aí nós viemos até em Santa Inês de taxi, de taxi, de Peritoró de ônibus, aí pegamos uma van para Coroatá, de Coroatá nos fomos de taxi para Timbiras. Aí de Timbiras, no outro dia, nós pegamos o ônibus até aqui.

Pesquisador: Então vocês saíram de ônibus de Timbiras e foram até aqui, em ônibus clandestino?

Daiane: Foi.

Pesquisador: Quantas horas de viagem?

Daiane: Três. Saímos de lá sexta-feira, umas dez horas. Chegamos aqui, domingo, sete horas da manhã.

(Daiane, 18, casada. Testemunho oral colhido em 22/07/2011 na cidade de Guariba/SP. Caderno de Entrevistas, p. 293).

O testemunho de Daiane revela as artimanhas que sua família realizou, em razão da perda do ônibus de linha no município de origem do núcleo familiarSanta Luzia - até a sua chegada em Timbiras, cidade na qual os ônibus clandestinos iriam partir no dia seguinte. Os gastos advindos do transporte da entrevistada, que estava grávida e de seu marido, por ônibus, van e taxi, foram feitos para otimizar a chegada deles até Timbiras, para no dia seguinte, partirem para Guariba. Lá já estavam seus pais e a família de dois irmãos (Caderno de entrevistas, p. 291- 292).

Codó, Timbiras e Coroatá constituem-se em pontos nodais dessa densa rede de deslocamento, não só em virtude do número de trabalhadores que se deslocam dos municípios para as cidades paulistas, mas também pela infraestrutura aí estabelecida - associação de empresas de ônibus, agências de viagem e vendedores de passagem - e pelo controle de informações dos integrantes dessa rede de deslocamento no que tange a colocação do migrante em um trabalho, geralmente no corte de cana e seu estabelecimento em uma residência no local de destino. Portanto, as redes de deslocamento de migrantes estão intimamente associadas às redes de aliciamento destes trabalhadores para o labor nos canaviais paulistas, como propõe Marinho (2010, p.18):

Percebe-se através do conceito de rede como essas regiões se conectam através dos fluxos de informações que circulam através das redes familiares e pessoais e do contato com os agentes que realizam a chamada viagem bem sucedida. 
Assim, as redes sociais de migração são tidas como instrumentos para entender as relações estabelecidas entre os agentes do movimento migratório.

As considerações de Marinho (2010, p. 18) validam a conexão entre redes de deslocamento, viabilizada por meio da malha rodoviária nacional que articulam os principais municípios de origem destes trabalhadores migrantes, reunindo redes territoriais materiais - rodovias - e redes de relações pessoais, aqui materializadas pelo papel das agencias de viagem como ambiente aglutinador de informações sobre as condições de trabalho e de residência nas cidades de destino.

Entretanto, essa rede de deslocamento abrange vários agentes sociais: proprietários de empresas de ônibus, donos de "agencias de viagem" e vendedores de passagem de ônibus em cidades e povoados distantes em outros municípios. Ela se desenvolveu, à medida que os deslocamentos de migrantes desta região do Maranhão foram se intensificando no decorrer dos anos 2000.

A experiência migratória dos primeiros trabalhadores maranhenses permitiu que alguns destes acumulassem uma série de informações essenciais, fortalecendo contatos importantes e inter-relações com agentes sociais que nutriam uma rede de relações pessoais que serviam de apoio para o transporte e o aliciamento de milhares de trabalhadores, e integrantes de sua família.

Alguns desses primeiros migrantes tornaram-se, com o tempo, agentes sociais de referência para o crescente deslocamento de maranhenses para vários municípios do país, e no caso em tela, para a área canavieira paulista.

Marinho (2010, p. 67 - 68) aponta a intensificação desse processo migratório a partir do município de Timbiras, principalmente depois da criação de uma agência de viagens no núcleo urbano timbirense, em local privilegiado no terminal rodoviário da cidade, em 2001.

As considerações de Marinho (2010) são importantes porque permitem compreender as múltiplas relações entre o município de Timbiras e as cidades em que irão se alocar "sazonalmente" homens, mulheres, ou famílias inteiras no interior paulista ou em outras unidades da federação, e as processadoras canavieiras, que constituem os empregadores destes agentes sociais, de forma 
direta, via representações da usina, ou, na maior parte das vezes, indiretamente, por meio da figura do aliciador.

Redes de deslocamento construídas a partir do aliciamento promovido por representantes diretos das usinas e de "gatos", originários de cidades do interior paulista e também de intermediários maranhenses, residentes em Timbiras.

Organizam-se redes de deslocamento a partir de itinerários oferecidos por empresas de ônibus - de origem regional ou de outros Estados do país -, agências de viagem - que se firmam tanto nas "cidades de origem" como nas principais "cidades de destino', e que se fortalecem com a venda indireta de passagens, por meio de intermediários que atuam em pequenas cidades e povoados do interior da área municipal que não contam com a presença material de uma agência de viagem.

Redes de relações pessoais que se consolidam a partir de anúncios em rádios locais, com alcance regional, ou com as práticas advindas da sociabilidade familiar, e dos grupos de amizade e vizinhança experimentados no Estado de origem.

Percebe-se que os itinerários construídos a partir das práticas de aliciamento e transporte vão organizando redes territoriais, que vão se sedimentando a partir de redes de relações pessoais, aproximando geograficamente territorialidades precárias alicerçadas de modo distinto e que podem reproduzir-se durante toda a vida ou parte significativa da vida dessas famílias de migrantes permanentemente temporários, conforme as considerações de Silva (2008, p. 179 - 180): Dessa sorte, homens e mulheres de lá e de cá vivem a dialética do transitório e sonham com o permanente. É essa engrenagem que os move nesses territórios permanentemente temporários.

\subsection{Itinerários migratórios de trabalhadores maranhenses: os roteiros da "precisão"}

$\mathrm{Na}$ pesquisa de campo foram entrevistados 57 agentes sociais nos municípios de Timbiras e Codó, no Estado do Maranhão e Guariba e Pradópolis no Estado de São Paulo. Destes, 25 corresponderam a trabalhadores migrantes, nos quais o núcleo familiar apresentava moradia nos municípios de Codó, e principalmente Timbiras. Recolhemos o registro oral de 24 integrantes das 
famílias de migrantes maranhenses que trabalharam nos canaviais paulistas entre os anos de 2000 e 2011, sendo 8 mães, 7 esposas, 5 pais, 1 filha, 1 padrasto, 1 sogra e 1 irmã. Foram ouvidos também 3 religiosos, 1 agente pastoral, 2 comerciantes e 2 dirigentes sindicais. Mais da metade $(58,4 \%)$ dos integrantes das famílias dos trabalhadores migrantes possuíam entre 40 e 60 anos de idade, sendo a maioria constituída pelos pais dos referido trabalhadores rurais. Observe a Tabela 19.

Tabela 19 - Faixa etária dos integrantes da família de trabalhadores maranhenses entrevistados.

\begin{tabular}{|c|c|c|}
\hline Faixa etária (anos) & Total de entrevistados & Em \% \\
\hline Menos de 20 & 2 & 8,3 \\
\hline $20-30$ & 4 & 16,7 \\
\hline $30-40$ & 1 & 4,2 \\
\hline $40-50$ & 7 & 29,2 \\
\hline $50-60$ & 7 & 29,2 \\
\hline 60 ou mais & 3 & 12,4 \\
\hline
\end{tabular}

Fonte: Pesquisa de campo (Janeiro de 2010/ Janeiro de 2011/ Julho de 2011/ Agosto de 2011). Organização: SILVA, A. E. R. (2012).

No conjunto, treze famílias foram entrevistadas, sendo que em sete delas contávamos com a presença no local dos trabalhadores migrantes e em seis os trabalhadores rurais estavam ausentes. Pudemos então acompanhar os integrantes dessas seis famílias maranhenses entre o espaço social das cidades paulistas e a sede do município de Timbiras e Codó, que serviam de residência para o núcleo de seus familiares no leste maranhense. Das treze famílias mencionadas, dez eram originárias ou residentes no município de Timbiras e três no de Codó. A pesquisa de campo foi realizada em dois momentos nos municípios de Timbiras e Codó (Janeiro de 2010 e Janeiro de 2011) e em três períodos nas cidades de Pradópolis e Guariba (Outubro de 2010, Julho e Agosto de 2011), envolvendo a coleta de testemunhos orais de 57 pessoas: 36 homens e 21 mulheres. A faixa etária dos integrantes das famílias dos trabalhadores rurais entrevistados pode ser observada por meio da Tabela 20. 
Tabela 20 - Faixa de idade dos maranhenses entrevistados que trabalharam na safra canavieira paulista (2000 - 2011).

\begin{tabular}{|c|c|c|}
\hline Faixa etária (anos) & Total de entrevistados & Em \% \\
\hline $20-30$ & 17 & $68 \%$ \\
\hline $30-40$ & 4 & $16 \%$ \\
\hline $40-50$ & 3 & $12 \%$ \\
\hline $50-60$ & 1 & $4 \%$ \\
\hline
\end{tabular}

Fonte: Pesquisa de campo (Janeiro de 2010/ Janeiro de 2011/ Julho de 2011/ Agosto de 2011). Organização: SILVA, A. E. R. (2012).

Por meio da Tabela 20, percebe-se que a maior parte dos trabalhadores rurais maranhenses entrevistados encontravam-se na faixa entre os 20 e 30 anos de idade, envolvendo, portanto, trabalhadores com elevado potencial produtivo nas lides da colheita da gramínea, como requerem as unidades processadoras instaladas no Centro Sul do país, como atestam as pesquisas de Alves ( 2006, p. 96; 2007, p. 40), Novaes ( 2007, p. 97), Silva ( 2006, p. 128; 2007; 2008). Este processo seletivo apurado, realizado pela seção de recursos humanos das unidades sucroalcooleiras, objetiva elevar os índices de produtividade a partir do aproveitamento máximo da matéria-prima e do consumo da força de trabalho dos mais jovens, estimulados a aumentarem o seu rendimento pelo ganho por produção. Trata-se de um artifício das empresas canavieiras de maximizarem a exploração da força de trabalho no corte manual da gramínea, em um contexto em que o custo dessa força de trabalho é menos dispendioso do que a implantação de colheitadeiras e a substituição da queima da palha da cana durante a safra, em razão das limitações da planta para o corte mecanizado e também da exploração dos terrenos pela máquina agrícola. A busca pelos "campeões de produtividade" (NOVAES, 2007, p. 97), pelos portadores do prêmio "podão de ouro" (SILVA, 2006, p. 128) ou executores do "bingo da morte", no dizer de Thomaz Jr. (2002) significam a abreviação da vida de trabalhadores, sobretudo do sexo masculino, reduzidos ao consumo de força física e energia nos talhões da gramínea. Representou também uma diminuição drástica do emprego de trabalhadoras na atividade do corte da cana em razão da alta produtividade requerida por parte das usinas e aí associadas à força física, em uma atividade 
laboral que comporta um período útil de trabalho, situado em torno dos quinze anos (SILVA, 2008, p. 13).

No que remete ao estado civil, a maior parte dos testemunhos orais colhidos, ou seja, 56\% referem-se a trabalhadores casados. Os solteiros representam $40 \%$ dos entrevistados e somente um migrante maranhense era separado. Veja a Tabela 21 :

Tabela 21 - Estado civil dos maranhenses entrevistados que trabalharam na safra canavieira paulista (2000 - 2011).

\begin{tabular}{|c|c|c|}
\hline Estado civil & Total de entrevistados & Em \% \\
\hline Casado & 14 & 56 \\
\hline Solteiro & 10 & 40 \\
\hline Separado & 1 & 4 \\
\hline
\end{tabular}

Fonte: Pesquisa de campo (Janeiro de 2010/ Janeiro de 2011/ Julho de 2011/ Agosto de 2011) Organização: SILVA, A. E. R. (2012).

Embora premidos pelas necessidades materiais, os objetivos da migração e a aplicação dos recursos poupados durante o trabalho na lavoura canavieira são distintos entre solteiros e casados. Ainda no que se refere aos primeiros, o deslocamento sazonal para o labor nos talhões da gramínea pode estar associado à busca de rendimentos para a compra do terreno e a construção da casa na cidade.

A maior parte dos trabalhadores rurais entrevistados apresenta o núcleo familiar residindo no município de Timbiras (80\%), sendo que 11 deles, ou seja, $44 \%$ possui integrantes da família residindo na cidade e 9 migrantes maranhenses têm familiares que moram nos povoados do interior do município. Cinco trabalhadores entrevistados residem no município de Codó, todos eles habitando o núcleo urbano da sede municipal. Observe a Tabela 22: 
Tabela 22 - Localização da residência do núcleo familiar dos entrevistados que trabalharam na safra canavieira paulista (2000 - 2011).

\begin{tabular}{|l|l|c|c|}
\hline \multicolumn{2}{|c|}{ Município } & Total de entrevistados & Em \% \\
\hline Codó & Sede do município & 5 & $20 \%$ \\
\hline \multirow{3}{*}{ Timbiras } & Sede do município & 11 & $44 \%$ \\
\cline { 2 - 4 } & Povoados & 9 & $36 \%$ \\
\hline
\end{tabular}

Fonte: Pesquisa de campo (Janeiro de 2010/ Janeiro de 2011/ Julho de 2011/ Agosto de 2011) Organização: SILVA, A. E. R. (2012).

A fronteira entre o urbano e o rural é muito tênue nos dois municípios do leste maranhense, visto que os processos de expropriação camponesa e o despejo de famílias das grandes propriedades rurais, intensificados desde a década de 1970, gerou um rápido crescimento da população urbana, contudo com uma parcela significativa da população residente na cidade, dedicando-se às lides agrícolas, em virtude do pequeno volume de empregos disponíveis na sede municipal (Carneiro et al., 2008)

Constituiu-se, portanto uma "territorialidade de ponta de rua" conformada na periferia da sede municipal, com expressiva parcela de famílias com integrantes que migraram para o trabalho no corte da cana, ou em outras atividades econômicas no Centro-Sul do país ou para a região amazônica, e que lidam com a atividade agrícola nos municípios maranhenses, a partir da prática do arrendamento, como pudemos ressaltar no capítulo 1.

Dentro desse contexto, 4 trabalhadores rurais que residem na sede do município de Timbiras, na qual a família apresenta integrantes trabalhando na terra, na condição de pequeno proprietário, posseiro ou foreiro afirmaram ainda possuir uma morada na unidade camponesa.

A migração rural-urbana municipal e a de longa distância apresenta vários significados para as famílias e para o trabalhadores migrantes, demonstrando que este processo social atinge todos os seus integrantes: os que partiram, os que partem, os que permanecem e os que irão partir. No que reporta a essas considerações atentaremos no próximo subcapítulo, a uma análise mais detida sobre as implicações do processo migratório no histórico das famílias dos trabalhadores migrantes. 


\subsection{Itinerário migratório das famílias dos trabalhadores migrantes}

Das seis experiências migratórias de famílias de trabalhadores migrantes que acompanhamos no Maranhão e em São Paulo, escolhemos os testemunhos orais de quatro famílias pela relevância de seu significado de resistência contra um histórico processo de empobrecimento. Itinerários migratórios de duas outras famílias de trabalhadores maranhenses foram selecionadas por apresentarem desdobramentos destoantes das primeiras famílias elencadas: em um caso trata-se de uma migração realizada ao longo da vida familiar de cidade para cidade, na condição de expropriado, e aproximandose do que Silva (2004) indica como "sobrante" e que Pontes (2010) destaca em seu estudo. No outra situação acompanharemos os itinerários de uma família, que fugindo sempre da precisão, encontrou em um projeto de assentamento de reforma agrária melhores condições para promover a sua reprodução social e a sua resistência no mundo por meio do trabalho dos integrantes da família na terra.

\subsubsection{Família de Odair (Codó/MA)}

"É bom, lá é bom, mas existe o outro lado, se eu não conseguir emprego, serviço lá para ficar, para manter meus filhos, eu não posso ficar lá, então tem que voltar e pronto" 43

Odair tem 37 anos de idade, é natural do município de Codó, do povoado Queimados. Tem três filhos e é separado. Os integrantes de seu núcleo familiar entrevistados foram sua irmã, Deusuída, professora, com 40 anos de idade, casada e com três filhos casada e seu irmão caçula Antônio Nilton, comerciário, 29 anos e solteiro. Por meio dos testemunhos orais colhidos obtemos informações sobre as experiências migratórias da família.

O trabalhador maranhense estudou até o sétimo ano do Ensino Fundamental. Os deslocamentos que realizara até 2001, se restringiam aos limites do município de Codó, como atesta o registro oral do entrevistado:

\footnotetext{
${ }^{43}$ Fala proferida por Odair ao ser indagado pelo pesquisador sobre as possibilidades de voltar a morar e trabalhar no Maranhão. (Odair, 37, separado. Testemunho oral colhido em 24/10/2010, na cidade de Guariba/SP. Caderno de Entrevistas, p. 48),
} 
Meus pais vieram da roça. Eu nasci também lá, na zona rural. Mas como assim, meu pai? Meu pai tinha um comércio, tinha um comercinho lá na zona rural e eu também trabalhei lá. Depois veio o estudo, eu vim para a rua, estudei. Depois tive que voltar de novo para lá, minha mãe faleceu, meu pai teve problemas no comércio, não estava andando. Voltei, tomei conta. Casei e depois voltei de novo para a rua. Na rua, eu trabalhava numa fábrica de plástico, papel, tudo. (Odair, 37, separado. Testemunho oral colhido em 24/10/2010 na cidade de Guariba/SP. Caderno de Entrevistas, p. 41)

A testemunha foi o primeiro integrante da família a realizar uma migração de longa distância, deslocando-se em 2001 para trabalhar na capital paulista como ajudante na construção civil, na qual residiu no distrito de Guaianases. No ano seguinte voltou para Codó, advertido pela irmã que o alertara a respeito da saúde da mãe, que veio a falecer. Estabeleceu-se durante o período na casa de sua irmã Deusuída, no bairro de São Raimundo.

Segundo o entrevistado, em 5 de janeiro de 2003, deslocou-se para Guariba para trabalhar durante a safra de cana, em razão da falta de emprego em Codó.O trabalhador maranhense fez parte de um dos primeiros grupos de trabalhadores maranhenses, e em particular de Codó a migrar para a referida cidade paulista.

Trabalhou uma safra na Usina Maringá, e na Central Energético Moreno, desde 2004, nas funções de cortador de cana, e em tempos recentes, de auxiliar de fiscal. Na ocasião da entrevista, realizada em outubro de 2010, afirmou que não ia para Codó, desde 2008. Mora com dois, dos dois filhos, e um deles vive com a ex-sogra.

Nos anos de 2006, 2007 e 2008, organizou em conjunto com o Serviço Pastoral do Migrante a festa maranhense do Boi Bumbá em Guariba, contando com ampla participação dos maranhenses e também de trabalhadores migrantes procedentes de outros Estados do país que estavam alocados em Guariba (Veja a Figura 28).

Deusuída $^{44}$, é professora do Ensino Fundamental 1 da rede municipal de Codó. Tem três filhos, que possuem a idade de 17, 15 e 11 anos. É casada com

\footnotetext{
${ }^{44}$ Colhemos os testemunhos orais de Deusuída e Antônio Nilton, em 9 de Janeiro de 2010, com a intermediação do padre responsável pela Comissão Pastoral da Terra, no município de Codó.
} 
Aldemar, 43, que há cinco anos migra para os canaviais do Estado de São Paulo, em busca de trabalho. A professora contou-nos que o filho mais novo estava "passando por problemas" e que gostaria que o marido estivesse mais próximo do filho para auxiliá-la nestas questões (Testemunho oral colhido em 09/01/2010, na cidade de Codó/MA. Caderno de Entrevistas, p. 3.) Na pesquisa de campo, em janeiro de 2011, a entrevistada disse que em 2010 o marido permaneceu junto da família em Codó. Comentou sobre a grande quantidade de crianças criadas com a avó, distante do pai e da família que migrou para regiões distantes, em busca de melhores oportunidades de trabalho (Testemunho oral colhido em 09/01/2010, na cidade de Codó/MA. Caderno de Entrevistas, p. 2.)

Ela nasceu no povoado de Queimadas, município de Codó, na qual o deixou para estudar e trabalhar na sede do município. Segundo a entrevistada, faz vinte anos que mora na cidade de Codó. Trabalhou inicialmente em casa de família, até formar-se.

Veja no Mapa 12 os itinerários migratórios de integrantes da família de Odair entrevistados durante a pesquisa de campo.

Pouco mais de um ano depois, em 15 de janeiro de 2011, voltamos a encontrar os dois entrevistados, na residência deles, no bairro São Raimundo, sem a presença de mediadores locais. Lemos a transcrição do registro feito no ano anterior anotado em caderno de campo e deixamos a foto obtida no mesmo período. Esclarecemos pendências referentes a coleta do primeiro registro oral, como a idade do filhos e de Antônio Nilton, assim como da autorização dos entrevistados para o uso de seus prenomes na tese. O marido de Deusuída, não se encontrava na residência, nas duas ocasiões em que realizamos as entrevistas. No último testemunho Deusuída afirmou que Odair já tinha chegado em Codó, mas que estava há alguns dias no interior de Codó. Também relatou que o marido não partira para a safra canavieira no ano anterior (2010). Durante a atividade de campo em janeiro de 2011 encontramos Odair com o pai, na atividade comercial deste na praça, onde se concentram os taxis com destino a cidade de Timbiras e Coroatá. 


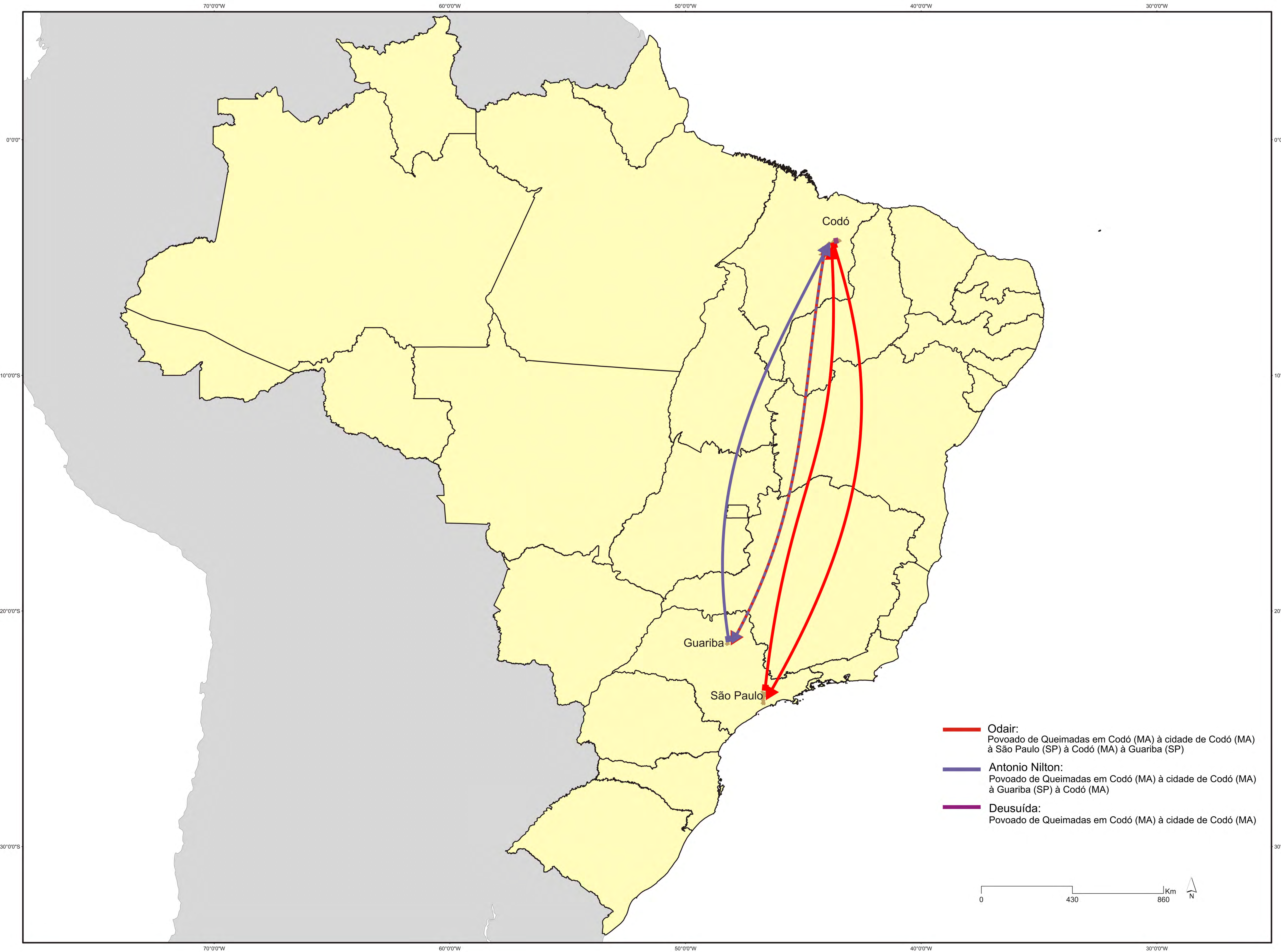


De acordo com Deusuída, seu marido trabalhou inicialmente na roça, alugando pequenas extensões de terra da área que pertencia a empresa Costa Pinto, e que depois da retomada da terra pela mesma empresa, os cultivos que realizava, na condição de rendeiro, foram impossibilitados. Para compensar a perda da produção de cultivos alimentares, na experiência supracitada, e a falta de trabalho com melhores rendimentos em Codó, o esposo decidiu migrar para o Estado de São Paulo, na atividade do corte da cana-de-açúcar.

Antônio Nilton é o irmão mais novo do tronco familiar de Deusuída e Odair. Disse que trabalhava inicialmente no comércio, na cidade de Codó, e que acompanhou os colegas que dirigiam-se para os canaviais paulistas em 2006. Fez uma safra e voltou para Codó, recuperou o antigo trabalho e permanece na cidade (Testemunho oral colhido em 09/01/2010, na cidade de Codó/MA. Caderno de Entrevistas, p. 3 - 4).

As experiências migratórias dos integrantes entrevistados da família do trabalhador migrante Odair mostram o processo de territorialização de "ponta de rua" que se materializou a partir do processo de modernização no Maranhão, iniciado no final da década de 1990. Dos testemunhos orais colhidos foi o único cujo itinerário dos deslocamentos passou pela metrópole paulistana nos anos 2000.

\subsubsection{Família de Francisco e Domingos (Timbiras/MA)}

"Toda a vida esse corre-corre" 45

Os irmãos Francisco e Domingos são trabalhadores rurais de Timbiras alocados em Pradópolis.

Seu avô materno nasceu no povoado de Bananal, no município de Codó e a sua mãe, dona Maria do Socorro, 56 anos, casada, em Chapadinha. Sempre foram trabalhadores rurais. Dona Maria do Socorro quebrou coco e trabalhou na roça. Veio para o município de Timbiras, já casada. A família morou dezesseis

45 Fala proferida por dona Maria do Socorro, 56, após o seu filho Domingos, ter respondido a pergunta sobre as conquistas materiais da família com a migração dos filhos para o corte de cana, no interior paulista. (Testemunho oral colhido em Timbiras/MA, em 19/01/2001. Caderno de Entrevistas, p. 138). 
anos na roça e residem na atual casa na cidade há sete anos. Não frequentou a escola, afirmando que "a escola era muito longe e nós chegávamos lá cansados e com fome. Meu pai pagava, mas não tinha como". (Maria do Socorro, 55, casada. Testemunho oral colhido em Timbiras, em 11/01/2010. Caderno de Entrevistas, p. 7).

Tem uma filha que mora em outra cidade, e o resto mora em Timbiras. $\mathrm{Na}$ ocasião da anotação do registro oral, apenas seu filho Francisco encontrava-se no interior paulista. Francisco, 25 anos, casado, realizou a primeira safra canavieira em 2007, pela Central Energética Ribeirão Preto, em 2007, usina sediada no município de Ribeirão Preto e que foi a falência em novembro de 2011, a partir da sua residência na sede do município de Pradópolis. No ano seguinte, não migrou para o trabalho no corte da cana em São Paulo, ficou em Timbiras, trabalhando no roçado da família em terra arrendada:

Pesquisador: E o ano em que você ficou aqui, você exerceu qual atividade?

Francisco: Só na roça, mesmo para a gente trabalhar mesmo, para comer mesmo.

(Francisco, 25, casado. Testemunho oral colhido em Timbiras/MA, em 19/01/2011. Caderno de Entrevistas, p. 129).

Nas outras duas vezes que migrou para o interior paulista para o trabalho na agricultura canavieira laborou nos talhões da gramínea que foram colhidos e processados pela Usina Santa Rita, unidade processadora instalada no município de Santa Rita do Passa Quatro, a partir da residência no núcleo urbano pradopolitano (Caderno de entrevistas, p. 129).

No momento da entrevista, disse que não faria a safra de 2011: "Vou ficar aqui, para ver o que é que eu faço, não é? Se não der a gente vai voltar de novo" (Caderno de Entrevistas, p. 131).

Acompanhe no Mapa 13 os itinerários migratórios de integrantes da família de Francisco e Domingos entrevistados durante a pesquisa de campo. 
Sua esposa, Edna, 23, acompanhou o marido em sua migração para o interior paulista em dois períodos, no ano de 2007 e em 2010. Ficou distante do marido durante a colheita da gramínea no ano de 2009. No vaivém das migrações da família para o interior paulista vieram também três filhos, que possuíam no registro da entrevista, respectivamente, dois anos, um ano, e o último, três meses de idade:

Pesquisador: E as crianças ficaram?

Edna: Levei tudo.

Pesquisador : Você levou tudo. Quantos filhos você tem?

Edna: Essa já nasceu lá, olha! Ela nasceu lá em Guariba. (...) É. Esse aqui, eu engravidei lá em 2007, e tive aqui. Esta aqui engravidei aqui e tive lá. E essa aqui engravidei lá e tive aqui. Foi um vai e vem.

Pesquisador: São três filhos que vocês têm?

Edna: É.

(Edna, 23, casada. Testemunho oral colhido em Timbiras/MA, em 19/01/2011. Caderno de Entrevistas, p. 132).

Francisco não concluiu o sexto ano do Ensino Fundamental e Edna estudou até o quinto ano do EF1. A família de Edna é procedente de Coroatá, e depois de casada estabeleceu-se com o marido na cidade de Timbiras.

Pesquisador: Você, o seu pai e a sua mãe, sua família são de Timbiras?

Edna: De Coroatá. Eu vim para Timbiras para morar com ele. Na verdade eu morava mais a avó dele. E aí eu conheci ele, se ajuntou,mas eu sou mesmo de Coroatá.

(Edna, 23, casada. Testemunho oral colhido em Timbiras/MA, em 19/01/2011. Caderno de Entrevistas, p. 133).

Domingos, 21, solteiro, participou da sua primeira safra de cana em 2010. Era o seu primeiro deslocamento de longa distância, e trabalhava na cidade de Timbiras, como ajudante de pedreiro, das sete às doze, de uma às quatro (Caderno de Entrevistas, p. 128). O entrevistado disse que não tinha pretensões em trabalhar na próxima colheita da gramínea em São Paulo, a mesma opinião sustentada pelo irmão, que foi o seu apoio familiar na cidade de Pradópolis. 
Rosana: E você pretende voltar também?

Domingos: Rapaz, esse ano, eu acho que volto não. Tem seguro.

Rosana: Também vai dar uma pausa agora?

Domingos: Recebi seguro.Três parcelas, não é?

(Domingos, 21, solteiro. Testemunho oral colhido em Timbiras/MA, em 19/01/2011. Caderno de Entrevistas, p. 134).

Os irmãos Francisco e Domingos foram os primeiros integrantes do tronco familiar a realizar uma migração de longa distância, demonstrando que a intensificação das precárias condições de reprodução social camponesa e a territorialização na "ponta de rua" acompanham a história da família há duas gerações. Revela também que as migrações para as cidades paulistas não precisam ser sucessivas e ininterruptas nos roteiros dos migrantes.

\subsubsection{Família de Raimundo (Timbiras/MA)}

"Aqui é quase tipo cativeiro, é um trabalho escravo, muito sofrido" ${ }^{46}$

Dona Maria Cleonice, tem quarenta e oito anos de idade, é casada e tem cinco filhos. É natural do povoado Capinal, localizado no extremo oeste do município de Timbiras, na divisa com Coroatá. Seu marido, Seu Sebastião, tem sessenta anos, e é natural de um povoado na área municipal de Chapadinha. Dois dos cinco filhos do casal de entrevistados já passaram por experiências migratórias de longa distância. Uma filha já migrou, acompanhando o marido para o trabalho na safra canavieira no Estado de São Paulo, a partir de Pradópolis, mas retornou ao município maranhense. O genro desloca-se para a labuta nos canaviais desde 2000, constituindo um dos primeiros timbirenses a se deslocar para o trabalho na safra da gramínea. em Segundo Dona Maria Cleonice,os filhos crescem sem a presença do pai, muito sofrimento, só a mãe cuidando das crianças (Caderno de Entrevistas, p. 10). irmã que foi acompanhando o marido já

\footnotetext{
${ }^{46}$ Fala proferida por dona Maria Cleonice, 48, ao testemunhar o descaso das autoridades diante do apoio material às famílias vitimadas pela forte inundação da bacia do Itapecuru, que atingiu o município em maio de 2009 e dos ônibus que semanalmente partem de Timbiras, levando centenas de trabalhadores e famílias para o labor nas atividades da lavoura de cana no estado de São Paulo. (Testemunho oral colhido em Timbiras/MA, em 11/01/2010. Caderno de Entrevistas, p. 11).
} 
há três anos e desde então não veio mais para o município timbirense. Têm irmãos, primos, sobrinhos, tem muita gente da família lá. O primeiro a migrar para São Paulo foi o genro há dez anos e os outros foram depois (Caderno de Entrevistas, p. 10).

Seu filho, Raimundo, 27 anos, é casado e está em Pradópolis desde 2006 e só voltou para visitar os pais, em janeiro de 2011, após o término da safra, no momento em que realizávamos a segunda entrevista com a família. Ele levou a esposa, Sandra, 27 anos para morarem em uma casa alugada na cidade paulista: "É, eu tava lá, depois ela foi, uns dez, onze meses, por aí" (Raimundo, 27, casado. Testemunho oral colhido em Timbiras, em 21/01/2011. Caderno de Entrevistas, p. 256). Sempre liga uma vez ou duas vezes por mês para os pais no Maranhão. $O$ casal tem uma filha, nascida em Timbiras.

Dona Maria Cleonice e Seu Sebastião estabeleceram-se no núcleo urbano de Timbiras há vinte e três anos e estão alocados na casa onde foi feita a entrevista desde setembro de 2009, quatro meses antes da realização da primeira entrevista. A outra casa alagou devido às chuvas intensas no início de maio de 2009 que provocaram grandes inundações na bacia hidrográfica do Itapecuru, atingindo vários municípios drenados pelo rio e seus tributários no leste maranhense. Graças a ajuda financeira de um filho que está no seminário no Estado do Paraná conseguiu doações de ordens religiosas depois da forte enchente. $\mathrm{O}$ filho que mora em Pradópolis também remeteu auxílio financeiro para os pais, que haviam perdido a casa com o fenômeno natural. Do governo, nas esferas local, estadual e federal não recebeu apoio substancial. Segundo a entrevistada, a restauração da vida social após os prejuízos materiais advindos com as fortes cheias, se deu mais pela colaboração das pessoas e das pastorais sociais atuantes no município (Caderno de entrevistas, p. 11).

Os itinerários de Raimundo não se restringem á área canavieira paulista. Apoiado na família de uma tia que reside no município de Campestre do Maranhão, onde foi instalada uma unidade agroindustrial da Maity Bioenergia S/A. O excerto da entrevista na página 245 aponta a primeira experiência de Raimundo com o trabalho na lavoura de cana, a partir de uma unidade processadora instalada na região tocantina do Estado do Maranhão: 
Pesquisador: Antes de ir pra São Paulo, você tinha passado por outro lugar? Trabalhado em outra cidade?

Raimundo: Já. Trabalhei no Campestre. Próximo a Imperatriz.

Pesquisador: Também usina de cana de açúcar?

Raimundo: Exatamente.

(...)

Pesquisador: Tá certo! E o que fez você ir para Campestre? Você tinha algum conhecido lá?

Raimundo: Não. Campestre eu tinha amigos, entendeu? Tinha a minha tia, e ainda hoje ela mora lá ainda. (Raimundo, 27, casado. Testemunho oral colhido em Timbiras, em 21/01/2011. Caderno de Entrevistas, p. $251,252)$.

A fala do entrevistado expõe a importância das redes de relações familiares, no caso, representadas pela família dos tios, os quais já moravam no município onde se encontrava instalada a usina, dispondo de informações e também de acomodações que aliviaram os temores econômicos e subjetivos resultantes dessa primeira experiência migratória de Raimundo. No entanto, esse apoio existente não foi suficiente para garantir o retorno do trabalhador rural de Timbiras para a realização das atividades do corte de cana. O entrevistado voltou para o município do leste maranhense e só depois migrou para o interior paulista, na busca de oportunidades de trabalho na colheita da gramínea. Nas palavras de Raimundo:

Raimundo: Não, isso foi em 2004. 2004, 2005, por aí.

Pesquisador: Depois de Campestre, você retornou pra cá ou foi direto para São Paulo?

Raimundo: Retornei pra cá.

Pesquisador: Retornou pra cá. Ficou um ano aqui?

Raimundo: Não, não fiquei um ano não.

Pesquisador: Menos de um ano?

Raimundo: De quarenta a cento e vinte dias, assim, mais ou menos nessa base.

Pesquisador: E você voltou a trabalhar em que aqui?

Raimundo: Aqui, nessa época já retornei, e fui ajudar meu pai mesmo. Depois eu viajei para São Paulo, pro Estado de São Paulo, na verdade, entendeu?Pro interior de São Paulo. (Raimundo, 27, casado. Testemunho oral colhido em Timbiras, em 21/01/2011. Caderno de Entrevistas, p. 254). 
A rápida passagem por Timbiras após o termino da colheita de cana na região tocantina revelam a escassez de emprego e as dificuldades de garantir a continuidade do trabalho de todos os integrantes da família na terra, como apontam Carneiro et al. $(2007,2008)$. As limitações na idade do pai de Raimundo $\mathrm{e}$ as restrições do sistema do arrendamento reduzem ainda mais as possibilidades da reprodução da jovem família de Raimundo na terra em seu município de origem. Desse modo, o retorno é pensado pelo entrevistado, de forma a viabilizar a melhora das condições de vida da família na cidade de Timbiras, a partir do investimento poupado com o trabalho nos canaviais, em uma atividade autônoma, assentada em conhecimentos técnicos que pretende adquirir na região onde se situa Pradópolis, para depois instalar o empreendimento no núcleo urbano timbirense. $O$ trecho da entrevista abaixo indica os elementos supracitados:

Pesquisador: E você pretende continuar lá no corte da cana?

Raimundo: Eu pretendo continuar lá, só que eu pretendo não só ir pra São Paulo para cortar cana, entendeu? Eu pretendo investir em mim próprio, ou seja, fazendo cursos, etc, para mim me aperfeiçoar numa outra área de serviço, de trabalho. Não pretendo sempre trabalhar no corte de cana, entendeu?

(...)

Pesquisador: Voltar pra cá [Timbiras] vocês não pensam também?

Raimundo: O meu plano entendeu, é conseguir algo, mas olhando aqui. Trabalhar aqui entendeu? É isso aí.

Pesquisador: Trabalhar aqui.

Raimundo: São Paulo é o terceiro país do mundo, mais rico, não é verdade? Ou seja, tudo lá é caro, se você não trabalha numa área que ganha um salário bom, um salário digno mesmo, fica difícil pra você conseguir as coisas, cem por cento lá, entendeu? São Paulo é um Estado muito rico, tudo lá se transforma em dinheiro, ou seja, tudo lá também é caro, entendeu? Ou seja lá, se você tem, tem, se você não tem, não tem. (Raimundo, 27 , casado. Testemunho oral colhido em Timbiras, em 21/01/2011. Caderno de Entrevistas, p. 262).

A referência à realidade socioeconômica paulista, experimentada a partir do trabalho penoso nos canaviais e da residência em Pradópolis, reproduz-se 
simbolicamente na fala de Raimundo, como o terceiro país do mundo mais rico, em contraposição ao que Silva (1999) designou como sendo os países do Norte, a região de origem dos trabalhadores migrantes dos canaviais paulistas. A riqueza associada ao país São Paulo está associada à disseminação dos valores de troca, em contraste com o compartilhamento dos valores de uso, ainda presentes na terra natal, às artimanhas tentadas para conseguir viver em um lugar "onde tudo lá é caro, se você não trabalha em uma área que ganha um salário bom, um salário digno mesmo". Reconhece, por outro lado, as condições aviltantes e os parcos rendimentos oriundos do trabalho nos canaviais, um salário que não é bom, nem digno, visto que não permite minimamente a reprodução da vida da família, sem dificuldades, cem por cento, que produz materialmente também nas sedes de municípios dependentes economicamente da cultura de cana-de-açúcar territorialidades precárias, em razão do alto custo, e, portanto, da negação dos elementos e bens indispensáveis à vida e a melhoria das condições sociais da família, desde uma alimentação limitada pela carência de dinheiro até uma formação educacional decente, autônoma e livre que lhes garanta ascensão social e a possibilidade de novas construções e leituras do mundo.

O testemunho oral de Raimundo aponta para as práticas cotidianas de resistência, aqui pensada no sentido conferido por SCOTT de milhares de agentes sociais que lutam diariamente para se perceberem e sentirem ampliados para além da condição de cortadores de cana, migrantes, camponeses pobres, sobrantes, etc. É uma luta de gerações para fugir de um histórico processo de empobrecimento, que os condena e impinge em seus corações e mentes de forma violenta as chagas da sujeição e da miséria. Migrar para a realização de trabalhos degradantes como nos eito dos canaviais representa as possibilidades de continuar existindo com "precisão", resistindo ao mesmo simbolicamente do cativeiro, de um trabalho escravo, muito sofrido.

Observe no Mapa 14 os itinerários migratórios de integrantes da família de Raimundo entrevistados durante a pesquisa de campo. 


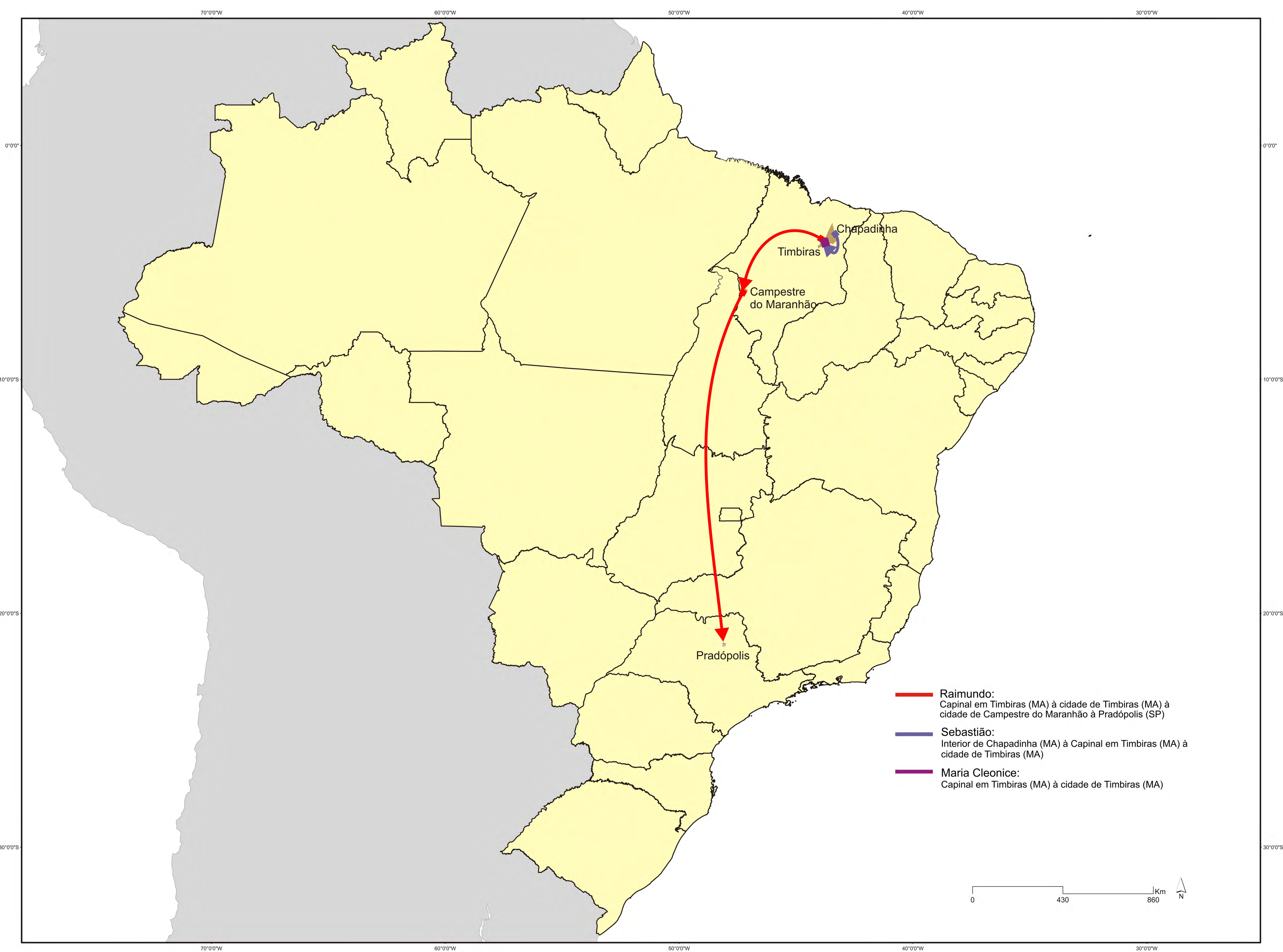




\subsubsection{Família de Jonas (Timbiras/MA)}

"Nossas condiçãozinha é pouca mesmo, não é, e foi preciso sair." 47

Jonas, 44, casado, é natural do município de Matias Olímpio, no Estado do Piauí, aí nós vem para cá para arrumar algum pouquinho, então, melhorar um pouquinho. ( Caderno de entrevistas, p. 20)

Têm cinco filhos, três adultos e dois menores, uma de 7 e outro de 15 anos de idade.

O primeiro integrante da família a deslocar-se para o trabalho nos canaviais a partir de Guariba foi seu filho João, em 2006. No ano seguinte ele "viajou” para a cidade paulista, acompanhado de um outro filho, que veio mais eu e voltou, não conseguiu trabalhar: trabalho aqui é pesado (Caderno de entrevistas, p. 17). João, o filho que trabalha nos talhões da gramínea e reside em Guariba em outra casa alugada, mas próximo de onde está instalado o pai. Jonas, contudo, concluiu as safras de 2007 e 2010, regressando para Timbiras, nesse intervalo, e dedicandose ao trabalho na roça da família em terras, que recebeu de herança e são compartilhadas por dez irmãos (Caderno de entrevistas, p. 18).

Apesar das terras e os cultivos da família encontrar-se em um contexto distinto daqueles que pagam renda ao proprietário da terra ou a seu preposto e não possui uma maior segurança jurídica da mesma, essa condição não isenta a recorrência à migração, como forma de melhorar as garantias de reprodução social da família, de preferência na terra. Um irmão de Jonas, há catorze anos está rodado para Boa Vista, em Roraima, e não entra em contato com a família.

Francisca, 42, sua esposa não acompanhou o marido na migração para o interior paulista. Permaneceu com os filhos em Timbiras, na casa da cidade e trabalhando, com os filhos maiores na unidade camponesa, e cuidando dos filhos menores, que frequentam a escola na sede do município. É natural de Lagoa do

\footnotetext{
${ }^{47}$ Fala de Francisca, 42, casada, após o pesquisador perguntar sobre os deslocamentos de Jonas para as atividades de garimpo. (Testemunho oral colhido em Guariba, em 16/01/2012. Caderno de Entrevistas, p. 74)
} 
Açúde ${ }^{48}$, localidade que a entrevistada situa na região da Baixada Maranhense, onde até hoje vive os seus nove irmãos e nasceram seus cinco filhos. De lá saiu, acompanhando a migração de integrantes do tronco familiar do esposo, e assim coloca:

Pesquisador: E a senhora saiu da região onde a senhora morava por quê?

Dona Francisca: Eu saí de lá, assim, por causa de que o velho meu sogro comprou um terreno aqui,não é?, Nos morava lá, mas tinha um terreno aqui. Tinha um terrenozinho pequeno, ele vendeu, comprou um aqui, não é? E aí nós viemos embora para cá, não é? E agora mesmo ele morreu e nós ficamos não é? (Francisca, 42, casada. Testemunho oral colhido em Timbiras, em 16/01/2011. Caderno de Entrevistas, p. 74)

Aqui Francisca, expõe a origem do deslocamento de sua família para Timbiras que acompanhava a migração de integrantes do núcleo familiar do marido. A entrevistada também fornece informações importantes que não foram referidas pelo esposo em seu testemunho oral registrado há quase três meses atrás em Guariba. Momentos difíceis que acompanharam a história da família, como o suicídio do filho, de dezenove anos, em 2009, quando Jonas encontravase junto a família em Timbiras, os deslocamentos do marido para a atividade do garimpo, deixando-a grávida, em Lagoa do Açude, como lembra Francisca:

Pesquisador: E aí, no caso, o seu Jonas, não é, ele há muito tempo sai de Timbiras para trabalhar em outros lugares, ou ele ficou a maior parte das vezes aqui?

Dona Francisca: Depois que nós chegamos aqui, ele já saiu duas vezes para São Paulo, não é? Quando nós morava na Baixada ele saiu três vezes, não é? Agora aqui no Timbiras, faz duas vezes que ele sai.

Pesquisador: E destas vezes que ele saiu da Baixada para trabalhar fora, foi para outros lugares?

Dona Francisca: Foi nesse tempo ele foi para o garimpo, é. Pesquisador: Para o garimpo?

Dona Francisca: Me deixou grávida, eu estava no mês de ganhar nenê, e aí ele foi para lá, não é. Nossas

\footnotetext{
${ }^{48} \mathrm{O}$ entrevistado deve referir-se a uma localidade situada na região da Baixada Maranhense, já que não existe nos dias de hoje, nenhum município do estado com esta denominação, e de acordo com a Enciclopédia dos Municípios Brasileiros) e pesquisa feita $\mathrm{n}$ o sítio do IBGE no histórico de todos os municípios do Maranhão, na referida região, não encontramos o local designado por dona Francisca.
} 
condiçãozinha é pouca mesmo, não é, e foi preciso sair. Mas nunca, assim, ele pôde de arrumar, adoeceu para lá, chegou doente. $O$ dinheiro que trouxe só deu para comprar remédio, é mesmo. (Francisca, 42, casada. Testemunho oral colhido em Timbiras/MA, em 16/01/2011. Caderno de Entrevistas, p. 74).

Jonas não se referiu às três vezes que "viajou" para o garimpo, quando inquirido na pesquisa de campo, em Guariba. Não queria esquecer, esses episódios que foram marcantes na vida da família, como lembra Francisca.

Deixar a família, os filhos pequenos, a mulher "no mês de ganhar nenê", voltar doente para casa, com o dinheiro suficiente apenas para comprar os remédios que necessitava, ações que de certa forma ferem o código de honra camponês e os objetivos materiais e simbólicos que sustentam a migração assentados na valorização da virilidade, do provimento da família, e do sucesso nas "viagens", (Silva, 2007) - foram justificadas pela esposa de Jonas, mesmo com o sofrimento daí decorrente, que lembrou, porém justificou, evitando as repercussões negativas no interior da memória coletiva : "nossas condiçãozinha é pouca mesmo, não é, e foi preciso sair".

O deslocamento de Jonas para a cidade de Guariba, para o trabalho na Usina Maringá, foi acompanhado da migração da família, que deixou a morada no povoado Santa Maria, no município de Timbiras, e se transferiu para uma casa no bairro da Horta, na periferia da cidade, pois, de acordo com o entrevistado:

Então para não vir para cá deixei a minha família na cidade e vim para cá para ver se eu sustento eles lá, não sei se eu vou garantir não, mas deixei eles na cidade, não é? Não sei se eu vou garantir o tempo todo, mas enquanto eu estou aqui eles estão lá na cidade. (“João", 44. Testemunho oral colhido em 24/10/2010, em Guariba. Caderno de Entrevistas. P. 16)

De acordo com Francisca, o estabelecimento da residência da família, na cidade se deve a outros motivos, a conclusão da educação formal (Ensino Fundamental) dos filhos:

Nós deixamos lá e viemos para cá, assim, por causa de que, nós temos um filho, e ele precisava estudar, estudar não é. 
E aí lá, os professores dele não ensinavam mais ele, não é? Por que lá, só ensina só, eu acho que até a quinta. Aí tem que vir para cá, não é? E aí lá não tinha mais como ele estudar, e foi preciso ele sair para cá, para botar ele no colégio, não é? Prá estudar. (Francisca, 42. Testemunho oral colhido em 16/01/2011. Caderno de Entrevistas. P. 76)

Seja em razão da migração de João, ou para botar o filho prá estudar, segundo o testemunho de Francisca, a vinda para a cidade, expõe as dificuldades da família em garantir o sustento e o trabalho dos seus integrantes na unidade camponesa. Por meio dos testemunhos orais de Jonas e Francisca pudemos analisar os danos materiais e simbólicos resultantes do processo migratório para terras distantes, experimentados por todos os integrantes da família, e não somente pelo agente social que se desloca. Francisca e os filhos que permaneceram em Timbiras lembram-se de outras histórias, de outras mutilações: ficar longe dos irmãos e da localidade onde nasceu na Baixada, longe do marido quando ganhou nenê, sem a presença que se matou com as próprias mãos, de outras práticas cotidianas de resistência, de outras formas de libertar-se dos conflitos e contradições que experimenta com o marido.

Acompanhe no Mapa 15 os itinerários migratórios de integrantes da família de Jonas que foram entrevistados durante a pesquisa de campo. 


\section{ITINERÁRIOS MIGRATÓRIOS DE INTEGRANTES ENTREVISTADOS DA FAMÍLIA DE JONAS}

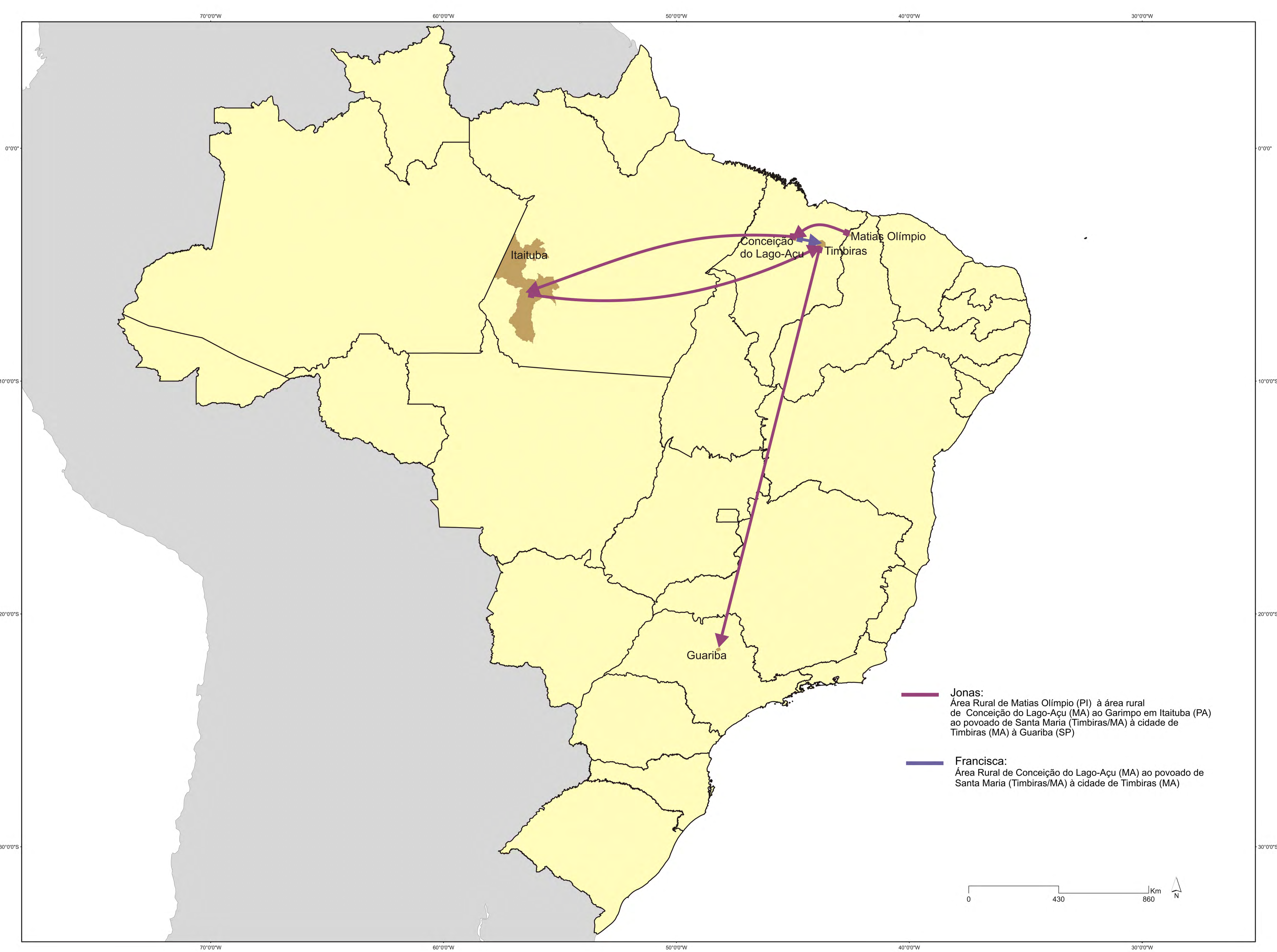




\subsubsection{Família de Elinaldo (Timbiras/MA)}

"Mas quando nós chegamos aqui, a gente fazia para morar, para pagar renda. Agora ninguém paga renda ${ }^{49,}$

Raimundo, 56, casado, nasceu no Estado do Piauí, o Estado de origem também de seus pais:

(...) que nós morava num lugar com nome Berdilongá ${ }^{50}$, e de lá a gente veio para o Maranhão, Coelho Neto, um bom tempo. Aí eu vim pra Codó, e Codó to aqui” . (...) No Piauí era sempre era falado que era meio ruim, e aí um irmão da minha mãe, que puxou ela aqui para o Maranhão, caçando acho que melhora, não sabe? (Testemunho oral colhido no povoado Pedra Preta, Timbiras/MA, em 20/01/2011. Caderno de Entrevistas, p. 185).

Do Piauí, a família de Raimundo estabeleceu no município maranhense de Coelho Neto, e lá conheceu dona Domingas, 56 , aposentada, com quem se casou e constituiu família. No ano de 1975, estabeleceram residência no bairro Trizidela, na cidade de Codó, e lá a família permaneceu por dezesseis anos, período em que dona Domingas assim testemunha:

Até que, porque, porque no tempo que nós morava em Codó, as coisas não eram muito fácil, aí ele vivia trabalhando, era fora de casa, passava mês, passava dois, passava seis meses. Teve uma vez que ele foi pra Itaituba [município situado a oeste do Pará] passou um bocado de mês pra lá, quando veio foi doente, aí não aguentou mais trabalhar $e$ aí trabalhou uns tempo empregado, aí desempregou, as criança, tudo pequenininha, eu digo, como é que nós vamos viver? Viver só nas porta das casa pedindo, é o que não há de acontecer. Então, enquanto a gente tá com essas criança pequena, a gente procura um lugarzinho no interior e vamo morar pra criar os filho, e aí foi a vinda nossa pra cá foi isso. (Domingas, 56, casada. Testemunho oral colhido no povoado Pedra Preta, Timbiras/MA, em 20/01/2011. Caderno de Entrevistas, p. 194).

\footnotetext{
${ }^{49}$ Trecho da fala de seu Raimundo, 56, casado, camponês, ao ser inquirido pelo pesquisador sobre as práticas cotidianas no povoado Pedra Preta, no município de Timbiras/MA. (Testemunho oral colhido no povoado Pedra Preta, Timbiras/MA, em 20/01/2011. Caderno de Entrevistas, p. 186).

50 O entrevistado deve referir-se a um povoado, situado no interior de um município piauiense, já que não existe nos dias de hoje, nenhum município do estado com esta denominação, e de acordo com a Enciclopédia dos Municípios Brasileiros e pesquisa feita $\mathrm{n}$ o sítio do IBGEno histórico de todos os municípios do Piauí não encontramos essa referência.
} 
O registro de dona Domingas revela a falta de oportunidades de trabalho no meio urbano, que proporcionou a migração do marido para o oeste do Pará, em um momento em que a atividade do garimpo no Pará, atraia milhares de trabalhadores, em busca de melhores condições de vida e de reprodução da unidade familiar. Um trabalho degradante, como muitos que acompanham a vida desses homens, mulheres e famílias em um histórico processo de empobrecimento. $\mathrm{O}$ consumo da força de trabalho do marido no Pará deixou o doente, aí não aguentou mais trabalhar, o desemprego, a procura de melhora, para livrar a família de uma condição limite, como a da mendicância, e pensando no futuro dos filhos, era preciso migrar novamente, desta vez para um lugarzinho no interior (...) pra criar os filho, já que residir na cidade, naquele contexto, não representava a possibilidade mínima de suprimento das necessidades alimentares mínimas da família e de um futuro sem horizontes. A territorialização camponesa significava simbolicamente e materialmente a única maneira de se deslumbrar uma perspectiva de reprodução social para os integrantes da família, para além dos limites da sobrevivência.

Todos os seis filhos de dona Domingas e seu Raimundo moram no município de Timbiras: três no povoado Pedra Preta, dois na cidade, e um no povoado Santo Antônio (Caderno de Entrevistas, p. 199).

Apenas dois netos partiram para o trabalho da safra da cana no Estado de São Paulo. Elinaldo, 20, solteiro,o neto caçula, migrou para o trabalho na safra canavieira paulista, no ano de 2010, a partir da cidade de Monte Aprazível, noroeste do Estado. Foi apoiado por um irmão, que passou por esta experiência um ano antes, e que naquele momento "viajava" pelo Estado de Minas Gerais (Caderno de Entrevistas, p. 197). Na ocasião da entrevista, Elinaldo, aguardava a opinião de outro irmão, que residia em Timbiras, sobre o deslocamento para o trabalho na safra da gramínea em São Paulo. Como se percebe, a possibilidade de reprodução social dos netos na terra, e próximo dos integrantes do tronco familiar, em Timbiras, apresenta dificuldades, jovens em idade produtiva e prestes a organizarem novos núcleos familiares.

Veja no Mapa 16 os itinerários migratórios de integrantes da família de Elinaldo entrevistados durante a pesquisa de campo. 


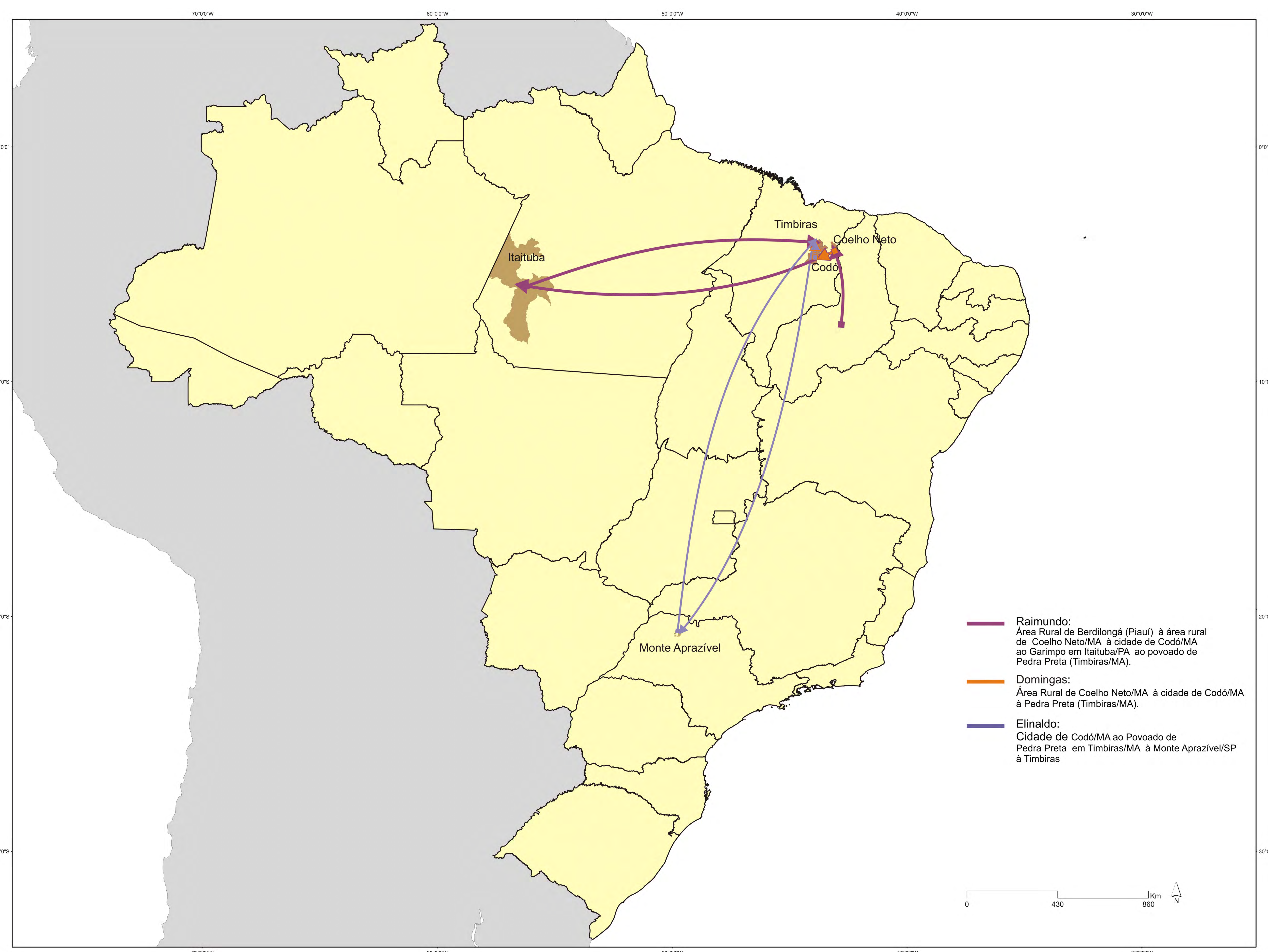


A criação de uma territorialidade camponesa no povoado Pedra Preta, no interior de Timbiras, permitiu materialmente o sonho de reprodução do trabalho da família na terra, mesmo que as limitações produtivas das roças, a falta de terras, a pouca presença do Estado em relação à promoção e atuação de políticas públicas substanciais para a reprodução social dessas famílias no campo, levem periodicamente muitos de seus integrantes a "viajar" para conseguir trabalho em terras distantes.

\subsubsection{Família de Randerson (Codó/MA)}

"Pra construir a casa, aí depois você vem pra cá, com o ganho pra ajudar ela mais a casa, e depois você volta de vez só quando tiver tudo ok, lá".

Randerson, 22, casado, nasceu na sede do município de Codó. Aos sete anos de idade, mudou-se com a mãe para a casa da avó na cidade de Timbiras, "porque nossa casa lá pegou fogo, minha mãe também se separou do meu pai, e a gente foi morar em Timbiras para cuidar da minha avó. Morava junto com a minha avó, que morava lá" (Caderno de Entrevistas, p. 299). Seu pai, já falecido trabalhava como varredor de rua e a mãe trabalhava na feira, vendendo verdura, ou seja, a família já residia no núcleo urbano e não possuíam roçados, mesmo cultivado em terras alheias. Somente, por meio do padrasto, a quem Randerson se refere como pai, que a família passou a ter um vínculo estreito com a terra, esta localizada no interior do município de Timbiras, no povoado das Mangueiras (Caderno de Entrevistas, p. 304).

Em Timbiras, Randerson trabalhava em várias atividades no núcleo urbano, diferente do ofício exercido por muitos trabalhadores maranhenses, que sob diversas modalidades de produção na terra, trabalhavam principalmente com a família, na unidade camponesa, vivendo de roça, como podemos perceber por meio do testemunho do entrevistado:

Pesquisador: Randerson, qual era a sua profissão em Timbiras?

Randerson: Eu trabalhava quase que gari lá, mexendo com serviço, caçamba, carregando pedra, areia, essas coisa. O serviço, mais era isso aí. Algumas vezes eu trabalhava de 
roça, eu mais meu pai, mas era raramente. Era difícil. Nesse serviço, foi o que eu trabalhei mais. (Randerson, 22, casado. Testemunho oral colhido em Guariba, em 22/07/2011. Caderno de Entrevistas, p. 298).

No registro oral de Randerson, fica exposto a pequena participação do trabalho do entrevistado na roça da família. A vida, desde a tenra infância na cidade, a separação dos pais, e a execução de diversos serviços urbanos reforçam essa experiência pessoal, mesmo apresentando um nível de escolaridade superior ao registrado pelos trabalhadores canavieiros das famílias entrevistadas:

A experiência de Randerson,nos remete às considerações de Pontes (2010, p. $8-9)$ :

ao mostrar que a migração de maranhenses constitui-se na ausência de alternativas, ou seja, não é uma migração pensada como forma de resistir, de se assalariar para manter a condição de pequeno agricultor como ressaltam diversos autores que estudam a problemática das migrações (....), mas a migração de maranhenses se dá pela questão da sobrevivência. Desta forma, não se trata de pensar a migração como processo complementar a renda familiar ou, principalmente, a migração como meio de manter a unidade de produção agrícola familiar ou, a estrutura de agricultor familiar: a sobrevivência da família, tornando-os ainda mais vulneráveis às normas de sujeição.

No excerto acima, a autora expõe a falta de alternativas de trabalho e melhoria das condições de vida, que marcam um contexto social que se espraia para amplas áreas empobrecidas deste país, incluindo aí o município de Timbiras, no leste maranhense. Territórios marcados por uma intensificação da precarização das condições de reprodução social do campesinato e pela escassez de empregos no meio urbano, lócus de residência da maior parte da população das unidades da federação deste país.

Redução da condição humana, no dizer de escravos da necessidade, a condição de mão-de-obra descartável. Migração forçada que converte decisão em "precisão"; viagem em deslocamento para roteiros conhecidos pelo trabalho degradante; embarque e desembarque, em carga e descarga; passageiro em 
"cabeça", trabalhador em "sobrante", condição de vida, em questão de sobrevivência.

Contexto diferente é o apresentado pela família de Francinalva, esposa de Randerson, que mesmo com o abandono do pai, manteve-se na terra, pertencente a família materna:

Pesquisador: Então, a sua família, a sua mãe ela tem a terra porque a família dela tinha?

Francinalva: Tinha.

Pesquisador: Certo! Então vocês desde pequenos então, cuidaram da terra?

Francinalva: Da terra.

Pesquisador: E lá a terra dela em Timbiras, é da família ou ela paga renda para alguém?

Francinalva: É da família.

(Francinalva, 28, casada. Testemunho oral colhido em em 22/07/2011, em Guariba/SP. Caderno de Entrevistas, 309 310)

O abandono da família pelo pai de Francinalva, não corresponde a fragmentação da unidade camponesa, pelo contrário, a migração dos irmãos não se processou diretamente para a cidade de Timbiras, mas a partir do ciclo de vida (SHANIN, 1976) produtivo em que este processo social se fazia imperante.

Pesquisador: E os seus irmãos Francinava, e depois os seus também, Randerson, vocês são os primeiros a sair de Timbiras e vir para cá, ou outros já passaram por experiências de sair de Timbiras e trabalhar fora?

Ah, os outros irmãos já. Saíram. Tem um que já está com oito anos em União Paulista, tem um que já passou dois anos e retornou de novo pra lá. (...).

Pesquisador: E você tem quantos irmãos?

Francinalva: São sete. Alias, tem mais dois em São Luis.

(Francinalva, 28, casada. Testemunho oral colhido em 22/07/2011, em Guariba/SP. Caderno de Entrevistas, 310)

A experiência migratória de três dos sete irmãos de Francinalva, para o trabalho nos canaviais em São Paulo, ou para a capital maranhense, é acrescida da sua, quando decide acompanhar o marido que laborava na safra de cana paulista. 
Guariba foi o primeiro município que o trabalhador maranhense viajou em busca de melhores condições de vida, como podemos observar no testemunho oral abaixo:

Pesquisador: E Guariba, aqui, no interior de São Paulo, é o primeiro lugar que você viaja?

Randerson: É o primeiro lugar, aqui em Guariba. Fiquei a maior parte do tempo em Timbiras.

Pesquisador: Você sempre ficou lá, então, não é? Não passou por outros lugares?

Randerson: Não. Sempre em Timbiras. Depois que eu vim pra cá, pra Guariba. (Randerson,22, casado. Testemunho oral colhido em 22/07/2011, em Guariba/SP. Caderno de Entrevistas, 304 - 305)

Para tanto, a concretização da migração de Randerson, contou com o apoio do primo, que já trabalhava na cultura da cana e que conseguiu-lhe um emprego e uma casa para residir na cidade paulista.

Desde então, há quatro anos seguidos Randerson migra para o trabalho na lavoura de cana-de-açúcar no Estado de São Paulo. Francinalva, 28, esposa do trabalhador maranhense veio para Guariba quatro meses depois da chegada do marido (Caderno de Entrevistas, p. 301). O casal tem dois filhos (com cinco anos, e dois anos e quatro meses, respectivamente) e estava na ocasião das entrevistas, aguardando a vinda do próximo filho e fazia planos para voltar para o Maranhão, ensaiada pelas ídas ocasionais em razão da parada nas atividades agrícolas da cultura da gramínea, no período da entressafra:

Pesquisador: Voltaram lá depois disso?

Randerson: Já, a gente voltou. Voltou no começo desse ano. A gente foi lá, no período que eu fiquei de férias, a gente foi lá. Agora a gente tá querendo ir embora agora para construir a nossa casa, mas vai depender do parto dela, como é que vai ser, para ver como é que a gente vai. (Randerson,22, casado. Testemunho oral colhido em 22/07/2011, em Guariba/SP. Caderno de Entrevistas, 302)

Os planos para a construção da casa dependem do contexto do nascimento do terceiro filho. A vinda inicial da esposa, para cuidar do bebê, e da mãe, que estava com a saúde fragilizada, aponta para esta tendência. Contudo, a 
volta de Randerson, desejada simbolicamente, materialmente se imiscui em incertezas.

A migração para o local de destino inicia-se, sobretudo, a partir de um deslocamento do integrante masculino da família em idade produtiva para o trabalho e o sustento da unidade doméstica. Depois de certo tempo, vem a esposa, mãe ou até avó, como indicou (Silva, 2008), irmãos, parentes, amigos e novas famílias maranhenses. Os planos de volta, após sucessivos ou ininterruptos períodos de trabalho nos canaviais, é antecipado por viagens com o intento para aquisição do terreno e construção da casa na cidade. Nesse contexto, geralmente o primeiro a "regressar" é a mulher, que no caso da família de Randerson, se alia aos interesses da maternidade e do cuidado com a saúde dos pais da esposa.

Randerson partira sozinho, solteiro, e a chegada de Francinalva, quatro meses depois, representa o desejo do casal de formar uma família e de Randerson preparar-se para tal empreitada, tentando reunir condições materiais para a concretização do regresso para Timbiras, apoiado pela esposa, que migra também para aliviar a peleja laboral do marido, realizando as tarefas domésticas da casa. A preocupação em preparar o terreno da volta para os filhos e para o tronco familiar, é assim expresso por Randerson, e complementado por Francinalva:

Randerson: Penso em voltar. Só que dessa vez eu viajo sozinho. Ela vai ficar, porque senão vai ficar muito pesada para ela, para mim também, porque tem que deixar a criança em escola, ir buscar depois, tudo isso. E tem a família dela também, que ela não gosta muito de ficar muito longe da família dela, não é? Mãe dela já está meio de idade, não é? Ela não quer ficar muito longe.

Randerson: Agora eu vou de vez agora. De vez.

Pesquisador: Então no caso, a Francinalva vai antes, pra ficar com a família, não é?

Francinalva: Vai junto.

Randerson: A gente vai junto. Vai junto e aí eu volto.

Pesquisador: Ah, certo!

Randerson: Só que eu vou passar um ano lá, depois é que eu venho.

Pesquisador: Vocês já tem casa lá ou vocês vão construir? 
Randerson: A gente vai construir primeiro.

Francinalva: A gente vai pra isso.

Randerson: Pra construir a casa, não é? Aí depois você vem pra cá, não é, com o ganho pra ajudar ela mais a casa, e depois você volta de vez só quando tiver tudo ok, lá.

Pesquisador: Como você pensa em continuar, indo e vindo todo ano?

Francinalva: Mais duas safra aqui.

(Caderno de entrevistas, p. 302 e 306)

O trecho selecionado da fala do casal revela o desejo da construção da casa e da fixação da família na cidade de Timbiras. Os preparativos para a concretização deste objetivo envolvem a permanência do casal durante um ano na sede do município maranhense, para construir a casa, iniciativa, que, porém, não cessa o deslocamento de Randerson para o trabalho na agricultura canavieira paulista, pois "pra ajudar ela mais a casa, e depois você volta de vez só quando tiver tudo ok, lá", é preciso migrar,segundo Francinalva, pelo menos, "mais duas safras aqui".

Temos aqui o desejo simbólico da fixação definitiva no município timbirense, que no plano material se dissolve no turbilhão de incertezas decorrentes dessa possibilidade, já que a volta de vez só será possível quando tiver tudo ok lá.

Com base nas discussões de Silva (1997), pode-se mencionar a existência de um corredor migratório, nesse caso, representado pelos deslocamentos entre o município do leste maranhense e as cidades do nordeste paulista. O referido corredor migratório pode desfazer-se ou recompor-se temporalmente. Novos locais de destino podem ser acrescidos ou extintos dos itinerários migratórios desses trabalhadores. Contudo, as incertezas decorrentes, tanto da falta de oportunidades de emprego na cidade de Timbiras quanto das limitações da unidade camponesa podem criar novos arranjos da experiência migratória. Estas incertezas alteram permanentemente os lás (e a construção de múltiplos territórios de migração), mas mantendo simbolicamente o cá, a "terra da gente", por meio de uma permanente migração temporária, como expõe Silva (1997).

A pesquisadora Maria Aparecida de Moraes Silva, ainda discute o significado e as ressignificações deste processo social a partir da construção permanente de "territórios permanentemente temporários": 
Tais situações definem os contornos da mobilidade desses múltiplos territórios migratórios que são permanentemente temporários. São vidas marcadas pela incerteza, transitoriedade e também pelo desejo de conseguirem realizar o projeto de distinção social, quer seja por meio da compra de algumas mercadorias do mundo capitalista, quer seja pelo cumprimento dos padrões comportamentais relativos aos gêneros. Os homens jovens desejam 0 sucesso, "subir na vida", por meio do trabalho; aqueles que possuem filhos, querem dar-lhes condições para que possam estudar e ter melhores oportunidades laborais futuras. Cumprem, assim, os papéis de provedores responsáveis e de chefes de família, As mulheres, enquanto mães ou avós, ao cuidarem da prole, ratificam seus papéis reprodutivos, enquanto muitas outras da região de destino se transformam em prostitutas, para atender ao mercado sexual criado pela migração. Dessa sorte homens e mulheres de lá e de cá vivem a dialética do transitório e sonham com o permanente. É essa engrenagem que os move nesses territórios permanentemente temporários. (Silva, 2008, p. 179 - 180)

Territórios permanentemente temporários (Silva, 2008), territórios precários (Oliveira, 2005), territorialidades construídas pela intensificação da precarização das condições de reprodução da vida, que inpingem nas famílias desses trabalhadores rurais marcas significativas - materiais e simbólicas - de um histórico processo de empobrecimento, experimentado nas múltiplas idas e vindas que se reproduzem no tempo e no espaço.

Veja no Mapa 17 os itinerários migratórios de integrantes da família de Randerson entrevistados durante a pesquisa de campo. 
ITINERÁRIOS MIGRATÓRIOS DE INTEGRANTES ENTREVISTADOS DA FAMÍLIA DA RANDERSON

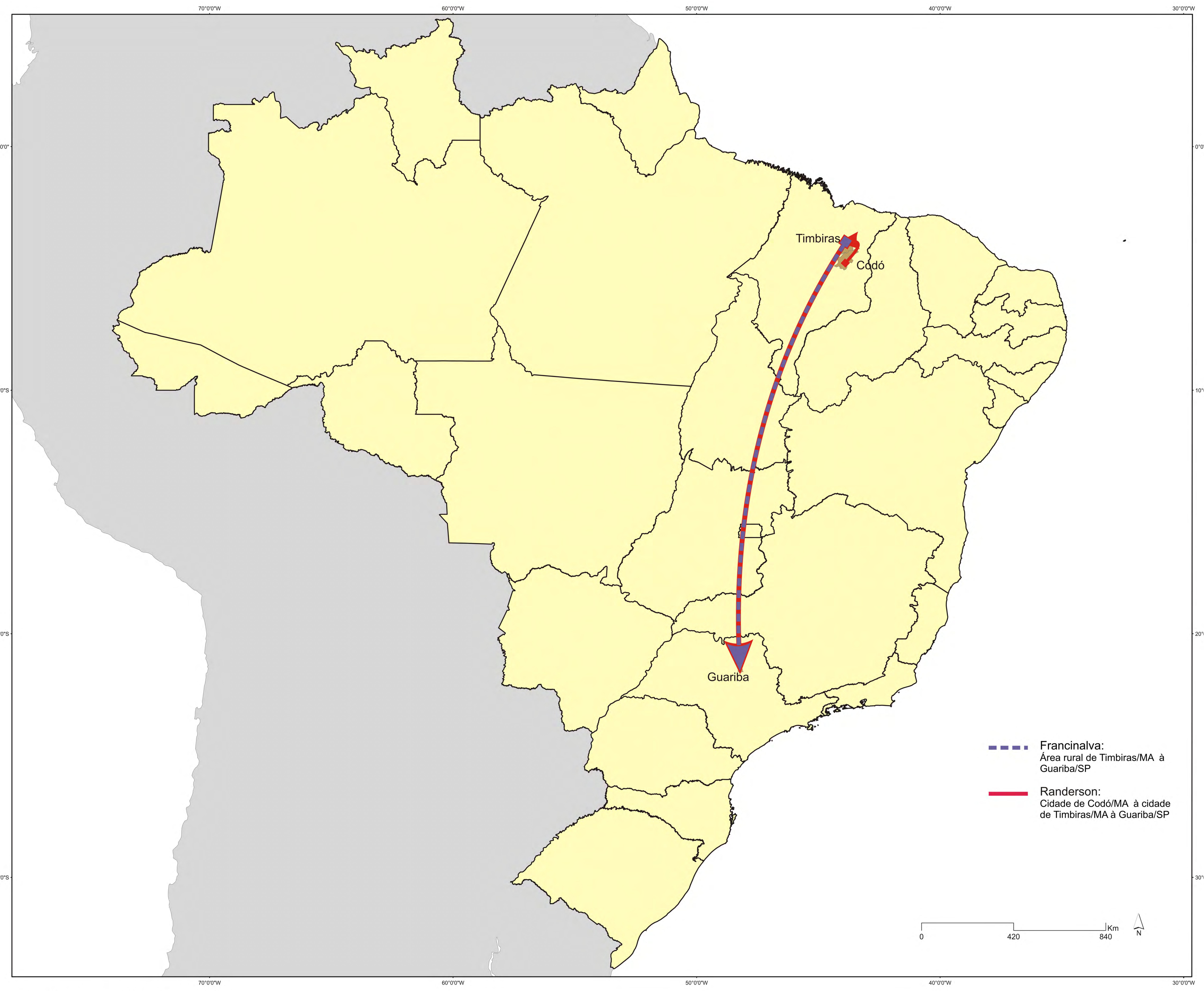




\section{CONSIDERAÇÕES FINAIS}

A migração maranhense para o trabalho nos canaviais paulistas pode ser explicada a partir de determinantes estruturais que atingem tanto o município de moradia do núcleo ou tronco familiar do trabalhador rural no Maranhão como na região onde situa a cidade paulista que ficará alocado durante o período desse deslocamento.

No Maranhão, a estrutura fundiária, concentrada nas mãos de famílias que detém o controle do poder político local ou de grupos econômicos extrarregionais, garante a exploração rentista da terra. Tal concentração fundiária assenta-se também nos projetos agropecuários que possibilitaram a grande criação de gado, ancorada em um movimento agressivo e massivo de despejo e expropriação de famílias que há gerações moravam no interior dos latifúndios, na condição de moradores, posseiros e foreiros, dispersos pelo interior da área municipal de Timbiras. As famílias camponesas, que foram expulsas, complementavam a produção familiar dos roçados com a venda da amêndoa, azeite ou carvão do coco da palmeira babaçu coletado e quebrado pelas mulheres camponesas e seus filhos menores. $\mathrm{O}$ ganho auferido pela prática agroextrativista é importante na segunda metade do ano, período em que se encerram as colheitas de arroz e de legumes, e que diminuem as chuvas que abundam no inverno de dezembro a maio.

Por meio deste processo, incentivado pelo Estado ditatorial, apoiado no âmbito estadual e municipal por correligionários e prepostos do governo Sarney, foi apropriada parte significativa das terras devolutas para por em ação o processo de modernização da agricultura, firmada na cessão de grandes extensões de terra para empresas agropecuárias com o fito de apoderarem especulativamente da renda da terra. $O$ processo em tela, também representou $O$ esvaziamento camponês das terras que tinham "dono", em razão dos interesses dos grandes proprietários rurais e grileiros, desejosos de obter vantagens e créditos decorrentes da política de incentivos fiscais preconizada por instituições estatais, principalmente durante o período da ditadura militar.

Segmentos do campesinato expropriado instalaram-se nos bairros periféricos de Timbiras, a partir da construção de suas rudimentares choças de 
adobe, perfazendo o que se conhece localmente por morar na "ponta de rua". Dessa forma, tem-se a origem do que denominamos de "territorialidade de ponta de rua", ou seja, uma experiência de vida na qual a família de origem camponesa, ameaçada e expulsa do campo, possui uma casa na cidade, embora continue mantendo o seu vínculo com a terra a partir da prática do arrendamento.

Esse sistema de exploração da terra consiste na entrega anual de braças de arroz para o dono da terra, como o pagamento pelo seu uso. O capitalismo rentista e os interesses de grupos econômicos associados ao agronegócio da carne apoderaram-se das melhores terras, restringindo o acesso massivo das famílias camponesas expulsas à esta modalidade de unidade camponesa.

As limitações temporais para o plantio e para a colheita do roçado, no caso dos rendeiros, representada aqui pelas privações no plantio da mandioca, produz uma intensificação da já precária condição de reprodução dos integrantes da família na terra, a partir dos três princípios indissociáveis que Woortmann (1990) apresenta: terra, trabalho e família. Outras famílias vivem nos povoados do interior timbirense e pagam anualmente o aluguel da terra em produto, mas se reproduzindo precariamente na condição de foreiros. A casa na "rua" é muitas vezes pensada como a alternativa possível de estabelecimento da unidade familiar, diante das ameaças de expulsão feitas pelo proprietário ou pelo novo dono das terras, caso seja vendida.

Para os jovens de origem camponesa que moram na "ponta de rua" ou nos povoados, as possibilidades de reprodução social sem "precisão" no foro ou arrendamento é bastante reduzida. Na cidade, há pouca criação de empregos estáveis. Com exceção dos aposentados e dos funcionários públicos, os trabalhadores permanentes são bastante escassos. Nesse sentido, como vimos em Carneiro et al. (2007), os programas de transferência de renda do governo federal como Bolsa Família e Bolsa Escola contribuem para a atenuação da condição de pobreza que atinge parte significativa das famílias do município. Os filhos menores crescem, repassam o benefício social, atingem a idade para trabalhar e, diante da construção de territorialidades precárias que acompanham a história da família, precisam migrar. Mas para onde?

A migração prossegue e se avoluma para as regiões onde os capitais demandam força de trabalho abundante e barata. Força física e energia passam a 
ser consumidas na movimentação das engrenagens de reprodução do padrão de acumulação capitalista. Alves (2007), Novaes (2007), Rumin (2004), Silva (2007) e Vettorassi (2006) fornecem nuances dessa face perversa do trabalho de migrantes maranhenses em canaviais paulistas: metas de produção diária, "cinco por um", birola, cãimbras, febres, dores no corpo, mutilações, mortes lentas, mortes súbitas, mortes!

O Estado mais rico do país, que exibe os maiores índices de produtividade agroindustrial e de trabalho no setor sucroenergético, que estampa na publicidade mundial o emblema do etanol como "energia limpa", é também o que esconde as condições degradantes de trabalho e as privações territorializadas em Timbiras, em Guariba e em Pradópolis.

Constatamos, portanto, a existência de uma migração forçada, direcionada para áreas com oferta de trabalho que, muitas vezes, apresentam condições análogas à do trabalho escravo contemporâneo. Destinos comuns em um passado recente, como regiões da Amazônia Legal, metrópoles industriais do Sudeste, assim como Brasília, cederam posição para cidades localizadas no epicentro do agronegócio canavieiro do país: o Estado de São Paulo. Perfaz o que Silva (2008) designa como mudança da cartografia migratória, ou seja, a modificação da origem dos trabalhadores migrantes para o labor nos canaviais paulistas. Constroem-se novas territorialidades migratórias, precárias, instáveis, indefinidas, conectadas igualmente à territorialidade precária das famílias que permanecem em Timbiras, seja nas "pontas de rua" ou nos povoados.

A territorialização precária atinge os que permanecem, os que partem e os que irão "viajar". Daí a importância da escolha da família do trabalhador migrante como unidade de referência deste estudo, pois por meio dos testemunhos orais percebemos que muitas delas apresentam uma longeva experiência migratória que acompanha a luta permanente destes agentes para escapar das amarras da pobreza e da miséria absolutas.

Pensamos a territorialidade no sentido conferido por Raffestin (1993) e Saquet (2008), conformada nas práticas cotidianas e envolta de relações de poder. Outrossim, aproximamos do conceito de território migratório pensado por Silva (2008) por incorporar os roteiros dos deslocamentos que permanentemente 
marcam a vida da família dos trabalhadores migrantes por meio de significações que são constantemente refeitas.

Para isso, propusemos neste trabalho um recorte que associasse 0 processo migratório em marcha na história da família ao processo de empobrecimento que sombreia suas trajetórias, territorializadas nestas idas e vindas.

Se há determinantes objetivos que permeiam esse processo social, há também os determinantes subjetivos, simbólicos, que na impossibilidade de se fazerem reais, nutrem os desejos de uma permanência estável, mesmo quando isso não é possível, pelo menos naquelas condições.

Suzuki (2007, p. 93) convida-nos a realizar uma leitura distinta do processo de modernização, ao valorizar a permanência dos conflitos no e a criação de outros no contexto de reprodução capitalista capital. Tal abordagem ancora-se em uma compreensão profunda deste processo para a história da agricultura, e não em um viés superficial, centrado no progresso técnico vislumbrado, sobretudo, na segunda metade do século passado.

O processo de modernização da agricultura no leste do Maranhão e na área ocupada pela agricultura canavieira em São Paulo reproduz outras formas de territorialização conflitantes com a lógica do capital. Podemos aqui mencionar os Projetos de Assentamento CIT/Novo Horizonte nos municípios de Timbiras e Codó, assim como o Assentamento Horto Guarani, entre Pradópolis e Guatapará, em São Paulo. Contudo, no que reporta às discussões e decisões acerca do fim da queima da palha da cana, os empresários agroindustriais tomaram a dianteira do processo. Cabe aos distintos segmentos da sociedade, tais como os sindicatos de trabalhadores rurais, o poder público local, dentre outros, defender o caráter público da questão.

Não queremos emprestar uma visão ou identidade regional à migração de timbirenses ou codoenses circunscrevendo territórios étnicos ou regionais. Ramella (1995) nos chama a atenção sobre o papel das informações confiáveis cambiadas entre familiares e amigos em São Paulo e no Maranhão. Na ausência ou falta dessas informações, os aliciadores, agenciadores, donos de agencias de viagem, intermediárias entram em cena, e com os contatos frequentes entre os que partiram e ficaram compõem uma multifacetada rede de relações pessoais 
que permitem a construção de territorialidades conflitantes e convergentes entre Timbiras, no Maranhão e Pradópolis e Guariba, em São Paulo.

Da mesma forma, verifica-se a intensificação do histórico processo de empobrecimento que acompanha a vida dos integrantes das famílias que migram e que se constituem por meio de redes de relações concretizadas no aliciamento, no deslocamento e no trabalho em São Paulo, perpetuando as redes de pobreza. Conflagra-se a formação de territorialidades precárias, as quais denominamos "territorialidade de ponta de rua" na sede do município de Timbiras e de "territorialidades migratórias" nas cidades que servem de residência aos migrantes no interior paulista.

A migração é um instrumento usado por pessoas e famílias para escapar das limitações e precariedades que marcam a reprodução social da família, a partir do trabalho na terra, e das condições estruturais de escassez de empregos no ambiente urbano no leste maranhense.

Com a expropriação promovida pelos latifundiários e a aquisição de terras por parte de empresas agropecuárias, as quais se apropriaram de grandes extensões de terra no município, famílias foram expulsas das fazendas e compulsoriamente instaladas nos bairros periféricos, que se avolumaram, conformando a territorialidade de "ponta de rua". O processo de expropriação camponesa supracitado ocorreu também em outras regiões do Estado do Maranhão, unidade da federação que a partir da Contagem da População, realizada em 1996 pelo IBGE, apresentou uma população urbana superior à rural.

O deslocamento massivo dos primeiros grupos de maranhenses ocorreu no final da década de 1990 e intensificou-se no decorrer dos anos 2000, aliado aos determinantes estruturais na região de moradia do tronco familiar dos trabalhadores migrantes e à demanda por força de trabalho requerida pelas unidades agroindustriais canavieiras no Centro-Sul do país.

O grande desafio de nossas reflexões é estabelecer um diálogo fecundo que permita desvendar, nessas idas e vindas, o significado e a continuidade destas territorialidades migratórias. 


\section{REFERÊNCIAS}

ALMEIDA, Alfredo Wagner Berno de. As secas do Nordeste e o Maranhão. São Luís: CPT, 1981.

ALVES, Francisco. Políticas Públicas Compensatórias para a Mecanização do Corte de Cana Crua: Indo Direto ao Ponto. In: Ruris . Revista do Centro de

Estudos Rurais. V. 3 No. 1 Campinas: Ceres /IFCH- Unicamp, 2009. P. $153-178$

Migração de Trabalhadores Rurais do Maranhão e Piauí

para o Corte de Cana em São Paulo. Será esse um fenômeno casual ou recorrente da estratégia empresarial do Complexo Agroindustrial Canavieiro? In: NOVAES, José Roberto; ALVES, Francisco. Migrantes. Trabalho e Trabalhadores no Complexo Agroindustrial Canavieiro. (os heróis do agronegócio brasileiro). São Carlos: EdUFScar, 2007. P. 21 - 49.

. Por que Morrem os Cortadores de Cana? In: Saúde e Sociedade Vol. $15 \mathrm{~N}^{\circ}$. 3 São Paulo: Faculdade de Saúde Pública/USP, setembro - dezembro 2006. P. 90 - 98.

ANDRADE, Arlete Fonseca de. Cana e Crack: Sintoma ou Problema? Um Estudo Sobre os Trabalhadores no Corte de Cana e o Consumo do Crack. Dissertação (Mestrado em Psicologia Social). São Paulo: PUC, 2003.

ANDRADE, Manuel Correia de. A Terra e o homem no Nordeste. Contribuição ao estudo da questão agrária no Nordeste. $7^{\mathrm{a}}$. Ed. revista e aumentada. São Paulo: Cortez Editora, 2005.

- Modernização e Pobreza: A expansão da

agroindústria canavieira e seu impacto ecológico e social. São Paulo:UNESP, 1994.

ARENDT, Hannah. A Condição Humana. 10 $10^{\mathrm{a}}$. Ed. Rio de Janeiro: Forense, 2009.

BACCARIN, José Giacomo; GEBARA, José Jorge. Mineiros no Corte da Cana na Região de Ribeirão Preto (SP) In: Travessia. Ano I N ${ }^{\circ}$. 1. São Paulo: Centro de Estudos Migratórios, 1988. P. $16-20$. 
BAENINGER, Rosana et al.. Regiões Metropolitanas e Polos Econômicos do Estado de São Paulo: Desigualdades e Indicadores para Políticas Sociais. Estudos Regionais: Pólo de Ribeirão Preto. Campinas: INEP/NEPP/NEPO/IE UNICAMP, 2009.

BACELLAR, Carlos de Almeida Prado. \& BRIOSCHI, Lucila Reis (Orgs.). Na Estrada do Anhanguera: uma visão regional da história paulista. São Paulo: Humanitas FFLCH/USP, 1999.

BEZERRA, Juscelino Eudâmidas. Agronegócio e ideologia: contribuições teóricas. In: Revista NERA. Ano $12 \mathrm{~N}^{\circ}$. 14 Presidente Prudente: Jan - Jun/2009. P. $112-124$.

BRIOSCHI, Lucila Reis. Caminhos do Ouro. In: Na Estrada do Anhanguera: uma visão regional da história paulista. São Paulo: Humanitas FFLCH/USP, 1999.

CARNEIRO, Marcelo Sampaio. A Evolução Recente da Economia Maranhense e suas Repercussões sobre a Agricultura Familiar. In: CARNEIRO, Marcelo Sampaio ; COSTA, Marcelo Sampaio Costa (Orgs.) A Terceira Margem do Rio: Ensaios Sobre a Realidade do Maranhão no Novo Milênio. São Luís: EDUFMA, 2009. P. 29-36.

CARNEIRO, Marcelo Sampaio; SOUZA, Andréa Joana; MARINHO, Karlene. O deslocamento temporário dos trabalhadores de Timbiras para a lavoura canavieira no Sudeste brasileiro. In: CARNEIRO, Marcelo Sampaio; MOURA, Flávia de Almeida (Orgs.) Migrações no Maranhão Contemporâneo. Uma análise do deslocamento de trabalhadores maranhenses rumo à lavoura canavieira de São Paulo. São Luís: UFMA- CPT/MA, 2008. P. 9 - 26.

CARNEIRO, Marcelo Sampaio; SOUSA, Andréa; MARINHO, Karlene. Migração, estrutura Agrária e Redes Sociais: Uma Análise do deslocamento de Trabalhadores Maranhenses Rumo à Lavoura da Cana em São Paulo. In: NOVAES, José Roberto; ALVES, Francisco. Migrantes. Trabalho e Trabalhadores no Complexo Agroindustrial Canavieiro. (os heróis do agronegócio brasileiro). São Carlos: EdUFScar, 2007. P. 215 - 232.

COMISSÃO PASTORAL DA TERRA. Conflitos no Campo Brasil 2010. São Paulo: Expressão Popular, 2011

Paulo: Expressão Popular, 2010. .Conflitos no Campo Brasil 2009. São 
COMISSÃO PASTORAL DA TERRA. Conflitos no Campo Brasil 2002. Goiânia: CPT, 2003.

COMISSÃO PASTORAL DA TERRA; REDE SOCIAL DE JUSTIÇA E DIREITOS HUMANOS. Agroenergia: Mitos e Impactos na América Latina. In: Cadernos de Formação. 2007.

COSTA, Rogério Haesbaert. Territórios Alternativos. 2a ${ }^{\mathrm{a}}$. Ed. São Paulo: Contexto, 2011.

. O Mito da Desterritorialização. Do "fim dos

territórios" à Multipolaridade. Rio de Janeiro: Bertrand Brasil, 2004.

FERREIRA, Antônio José de Araújo. Políticas Territoriais e a Reorganização do Espaço Maranhense. Tese (Doutorado em Geografia Humana). São Paulo: FFLCH/USP, 2008.

FERREIRA, Márcia Milena Galdez. Práticas Culturais de Migrantes Nordestinos no Maranhão (1930 - 2010) In: X Encontro Nacional de História Oral. Recife: abril de 2010. $6 \mathrm{f}$

FIGUEIRA, Ricardo Rezende. Pisando Fora da Própria Sombra. A Escravidão por Dívida no Brasil Contemporâneo. Rio de Janeiro: Civilização Brasileira, 2004.

FRAZÃO FILHO, Francisco Alves. Migração Temporária e PRONAF. Uma Combinação Estratégica na Trajetória Social de Populações Camponesas em Francinópolis-PI. Dissertação( Mestrado em Políticas Públicas). Teresina: UFPI, 2009.

GARCIA JÚNIOR, Afrânio Raul. O Sul: Caminho do Roçado. Brasília: Editora UnB, 1990.

GARCIA JÚNIOR, Afrânio Raul. Terra de Trabalho. Trabalho familiar de Pequenos Produtores. Rio de Janeiro: Paz e Terra, 1983.

GORDINHO, Margarida Cintra. Luiz Ometto: o Legado. São Paulo: Escrita Serviços, 2005. 
HEREDIA, Beatriz Maria Alsácia de. A Morada da Vida. Trabalho Familiar de Pequenos Produtores do Nordeste do Brasil. Rio de Janeiro: Paz e Terra, 1979.

IBGE. Censo Agropecuário 2006. Brasil.Grandes Regiões e Unidades da Federação. Rio de Janeiro: 2009.

IBGE. Enciclopédia dos Municípios Brasileiros. XV Volume Rio de Janeiro: 1959. P. 363- 366.

MARINHO, Karlene Carvalho. Viagem Toda Sexta: Análise do Processo de Intermediação do Deslocamento de Trabalhadores Migrantes de Timbiras-MA para a lavoura canavieira do sudeste brasileiro. Dissertação (Mestrado em Ciências Sociais). São Luís: UFMA, 2010.

MARTINS, José de Souza Martins. Migrações Temporárias, problema para quem? In: Exclusão social e a nova desigualdade. $2^{\mathrm{a}}$. Ed. São Paulo: Paulus, 2003. P. $39-47$.

História Lenta. 2a . Ed. São Paulo: Hucitec,1999.

O Poder do Atraso: Ensaios de Sociologia da O vôo das andorinhas: migrações temporárias no Brasil. In: Não há terra para plantar neste verão: O cerco das terras indígenas e das terras de trabalho no renascimento político do campo. $2^{a}$. Ed. Petrópolis: Vozes,1988. P. 44-61.

MAY, Peter H.. Palmeiras em Chamas. Transformação Agrária e Justiça Social na Zona do Babaçu. São Luís: EMAPA/FINEP/Fundação Ford, 1990.

MELO, Beatriz Medeiros de. Migração, Memória e Território. O Trabalhador Rural nordestino na Ibaté paulista. Dissertação (Mestrado em Geografia) Presidente Prudente: Faculdade de Ciências e Tecnologia de Presidente Prudente/ UNESP, 2007.

MENEZES, Marilda Aparecida de. Redes e Enredos nas Trilhas dos Migrantes. Rio de Janeiro: Relume Dumará, 2002. 
MENEZES, Marilda Aparecida de. Questionamento às Categorias "Migrante de Retorno" e "Migrante". In: Boletim de Geografia Teorética. Vol 22 №. 43- 44. Rio Claro: UNESP, 1992. P. $120-123$.

MOURA, Flávia de Almeida. Escravos da Precisão: Economia Familiar e Estratégias de Sobrevivência de Trabalhadores Rurais em Codó (MA) São Luís: EDUFMA, 2009.

NOVAES, José Roberto Pereira. Trabalho nos Canaviais. Os jovens entre a enxada e o facão. In: Ruris. Revista do Centro de Estudos Rurais. Vol. $3 \mathrm{~N}^{\circ} .1$ Campinas: Ceres / IFCH, 2009. P. 105 - 127.

. Campeões de produtividade: dores e febres nos canaviais paulistas. In: Estudos Avançados. Vol. 21, №. 59. São Paulo: IEA/USP, janeiro-abril 2007a. P. 167-177.

. Idas e vindas: disparidades e conexões

regionais. Um estudo sobre o trabalho temporário de nordestinos na safra da cana paulista. In: Migrantes. Trabalho e Trabalhadores no Complexo Agroindustrial Canavieiro. (os heróis do agronegócio brasileiro). São Carlos: EdUFScar, 2007b. P. 87 - 117.

OLIVEIRA, Ana Maria Soares de. Reordenamento Territorial e Produtivo do Agronegócio Canavieiro no Brasil e os Desdobramentos para o Trabalho. Tese (Doutorado em Geografia). Presidente Prudente: Faculdade de Ciências e Tecnologia, 2009.

OLIVEIRA, Ariovaldo Umbelino de. Os Posseiros Voltam a Assumir o Protagonismo da Luta Camponesa pela Terra no Brasil. In: COMISSÃO PASTORAL DA TERRA. Conflitos no Campo Brasil 2010. São Paulo: Expressão Popular, 2011. P. 55 - 62.

OLIVEIRA, Lucia Vanir Alves. O Migrante Nordestino, a Cultura e a Formação de Territórios em Caldas Novas/GO. Dissertação (Mestrado em Geografia). Uberlândia: UFU, 2005.

PONTES, Sabrina Kelly. Migrações de Trabalhadores Maranhenses para o Corte da Cana-de-Açúcar no Interior de São Paulo: o Percurso da "Precisão". Tese (Engenharia de Produção). São Carlos: UFSCar, 2010. 
PÓVOA NETO, Helion. Migrações internas e mobilidade do trabalho no Brasil atual. Novos desafios para a análise. In: HEIDEMANN,Heinz Dieter; SILVA, Sidney Antônio da.(Orgs.) In: Migração: nação, lugar e dinâmicas territoriais. São Paulo: Humanitas,2007. P. $45-56$.

PRADO. JUNIOR, Martinho. In Memorian 1843 - 1943.

RAFFESTIN, Claude. Por Uma Geografia do Poder. Trad. Maria Cecília França. São Paulo: Ática, 1993.

RUMIN, Cassiano Ricardo. Trabalho rural e saúde: um estudo sobre as condições de trabalho e sua relação com a saúde dos cortadores de cana-deaçúcar do município de Pacaembu (SP). Dissertação (Mestrado em Medicina Social). Ribeirão Preto: Faculdade de Medicina de Ribeirão Preto/ USP, 2004.

SAQUET, Marcos Aurélio. Abordagens e Concepções de Território. São Paulo: Expressão Popular, 2007.

SANTOS, Gislene Aparecida dos Santos. Redes e Fronteiras: o Caso da Migração de Sul-Catarinenses para os Estados Unidos. In: HEIDRICH, Álvaro Luiz et al. (Orgs.) A Emergência da Multiterritorialidade. A Ressignificação da Relação do Humano com o Espaço. Canoas/ Porto Alegre: Editora da ULBRA, Editora da UFRGS, 2008. P. 85 - 100.

SERVIÇO PASTORAL DO MIGRANTES. Vozes do Eito. Guariba: Eco das Letras, 2009.

interior paulista. Dossiê 2001-2003. Guariba: 2003 Rota da Mobilidade Humana para o

SILVA, André Eduardo Ribeiro da. A Territorialização da Agroindústria Sucroalcooleira: O Processo de Reestruturação Produtiva no Campo e os Trabalhadores Canavieiros da Fazenda Amália/SP. Dissertação (Mestrado em Geografia Humana). São Paulo: FFLCH-USP, 2007.

SILVA, José Carlos Aragão. Ser Livre e Ser Escravo: Memória e Identidades de Trabalhadores Maranhenses na região dos Cocais (1990 - 2008). Tese (Doutorado em História Cultural). Brasília: UnB, 2009. 
SILVA, Maria Aparecida de Moraes. Migrantes Maranhenses nas Terras Paulistas. (Mimeo) $201027 f$.

Produção de Alimentos e Agrocombustíveis no Contexto da Nova Divisão Mundial do Trabalho. In: Revista Pegada Vol. 9 N $^{\circ}$. 1 Presidente Prudente: CEGet FCT/ UNESP, outubro de 2008a. P. 63 - 80.

. Cortadores de Cana e os (não) Direitos. In:

Travessia Nº. 61. São Paulo: maio-agosto 2008b. P. 26 - 36.

\section{Expropriação da Terra, Violência e}

Migração: Camponeses Maranhenses no Corte da Cana em São Paulo. In: Cadernos CERU. Série 2 Vol. 19, No. 1. São Paulo: CERU/USP, Junho 2008c. P. $165-180$.

Agronegócio: a Reinvenção da Colônia. In:

SILVA, Maria Aparecida de Moraes et al. (Orgs.). Agrocombustíveis Solução? A Vida por um Fio no Eito dos Canaviais. São Paulo: Centro de Capacitação da Juventude, 2008 e. P. 4 -18.

Vidas de mulheres: dos cocais maranhenses às periferias das cidades canavieiras paulistas In: Seminário Internacional Fazendo Gênero 8: Corpo, Violência e Poder. Florianópolis: UFSC, agosto 2008e.

.Trabalho e trabalhadores na região do "mar

de cana e do rio de álcool". In: Migrantes. Trabalho e Trabalhadores no Complexo Agroindustrial Canavieiro. (os heróis do agronegócio brasileiro). São Carlos: EdUFScar, 2007a. P. 55 - 86.

A morte ronda os canaviais. paulistas In:

Reforma Agrária. Revista da Associação Brasileira de Reforma Agrária. Vol. 33 No. 2 Campinas: ABRA, Ago- Dez 2006 a P. 111 - 141.

Contribuições Metodológicas para a Análise das Migrações. In: DEMARTINI, Zeila de Brito Fabri; TRUZZI, Oswaldo(Orgs.) Estudos Migratórios: Perspectivas Metodológicas. São Carlos: EdUFSCar, 2005. P.53 - 86. 
SILVA, Maria Aparecida de Moraes. Errantes do Fim do Século. São Paulo: Editora Unesp,1999.

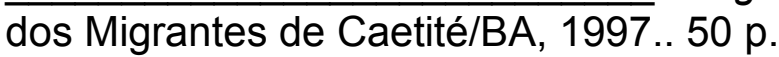

Migrar É Preciso. 1. ed. Caetité-BA: Pastoral . Destinos e Trajetórias de Camponeses

Migrantes. In: Anais do VIII Encontro da ABEP. Campinas: NEPO/UNICAMP, 1992. Disponível

SILVA, Maria Aparecida de Moraes et al. Do Karoshi no Japão à birola no Brasil: faces do trabalho no capitalismo mundializado. In: Revista NERA. Ano $9 \mathrm{~N}^{\circ} .8$ Presidente Prudente: NERA, julho - dezembro 2006.

SUAREZ, Maria Tereza Sales de Melo. Cassacos e Corumbas. São Paulo: Ática, 1977.

SUZUKI, Júlio César. Modernização, território e relação campo-cidade - uma outra leitura da modernização da agricultura. In: Agrária (São Paulo. Online), v. 6, p. 83-95, 2007.

THOMAZ JÚNIOR, Antônio. Por Trás dos Canaviais, os "nós da cana" : a relação capital $\mathrm{x}$ trabalho e o movimento sindical dos trabalhadores na agroindústria canavieira paulista. 1 ed. São Paulo: Annablume Editora / Fapesp, 2002.

VALE, Ana Lia Farias. Imigração de Nordestinos para Roraima. In: Estudos Avançados V. 20 Nº. 57. São Paulo: IEA/USP: Maio-Agosto 2006.

VETTORASSI, Andréa. Laços de Trabalho e Redes dos Migrantes: Um Estudo Sobre as Dimensões Objetivas e Subjetivas Presentes em Redes Sociais e Identidades de Grupos Migrantes de Serrana e Guariba/SP. Tese(Doutorado em Sociologia). CAMPINAS: UNICAMP, 2010

. Espaços Divididos e Silenciados: Um estudo sobre as relações sociais entre nativos e os "de fora" de uma cidade do interior paulista. Dissertação (Mestrado em Ciências Sociais). São Carlos: UFSCar, 2006. 